\title{
State Coal Profiles
}

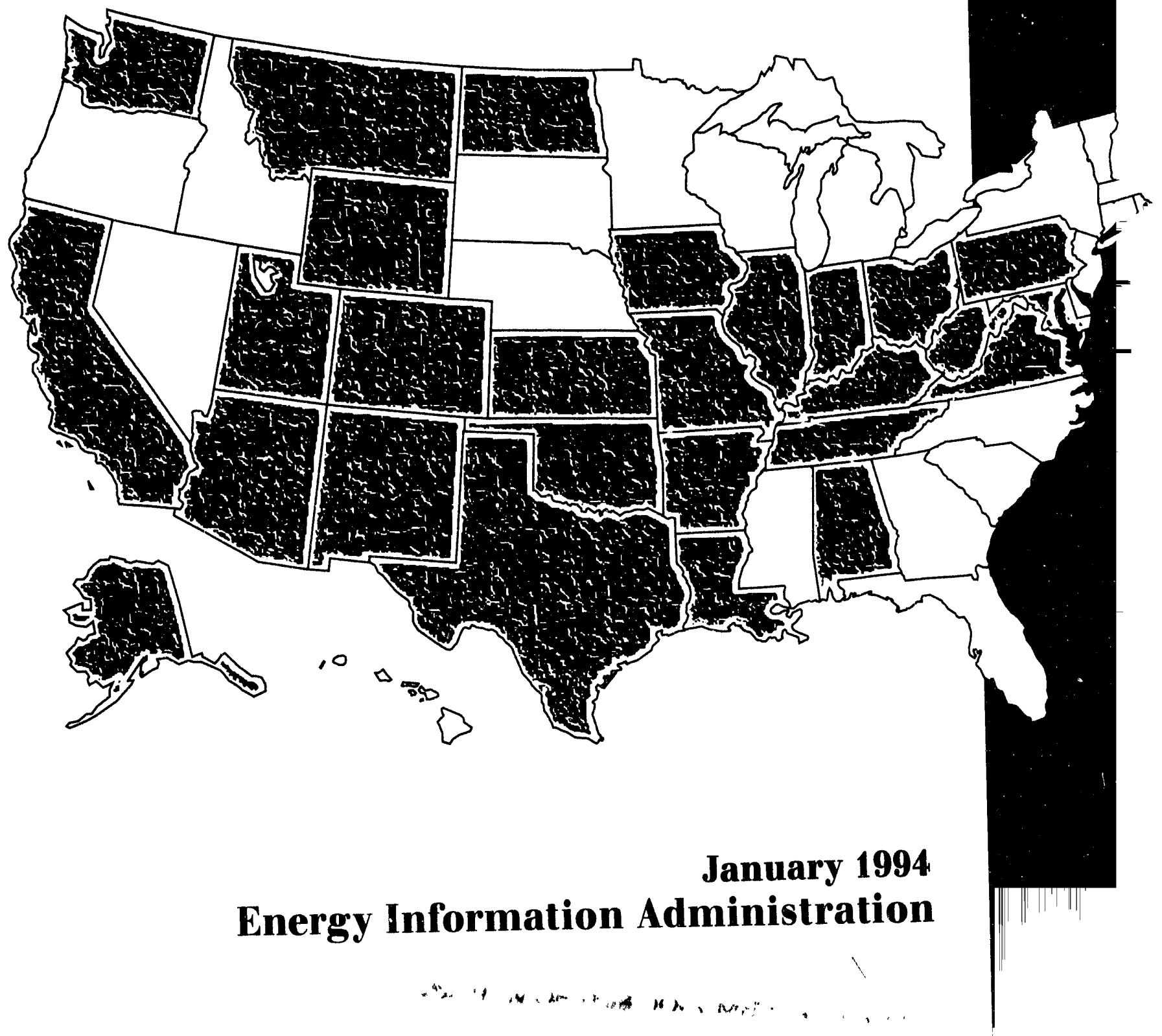


This publication and other Energy Information Administration (EIA) publications may be purchased from the Superintendent of Documents, U.S. Government Printing Office.

\title{
All telephone orders should be directed to:
}

U.S. Government Printing Office

McPherson Square Bookstore

1510 H Street, N.W.

Washington, DC 20005

(202) 653-2050

FAX (202)376-5055

9 a.m. to $4: 30$ p.m., eastern time, M-F
Superintendent of Documents

U.S. Government Printing Office

Washington, DC 20402

(202) 783-3238

FAX (202)512-2233

8 a.m. to 4 p.m., eastern time, M-F

\section{All mail orders should be directed to:}

\author{
U.S. Government Printing Office \\ P.O. Box 371954 \\ Pittsburgh, PA 15250-7954
}

Complimentary subscriptions and single issues are available to certain groups of subscribers, such as public and academic libraries, Federal, State, local and foreign governments, ElA survey respondents, and the media. For further information and for answers to questions on energy statistics, please contact EIA's National Energy Information Center. Address, telephone numbers, and hours are as follows:

National Energy Information Center, EI-231

Energy Information Administration

Forrestal Building, Room 1F-048

Washington, DC 20585

(202) $586-8800$

TTY: For people who are deaf or hard

of hearing: (202)586-1181

9 a.m. to 5 p.m., eastern time, M-F 
DOE/EIA-0576

Distribution Category UC-950

\title{
State Coal Profiles
}

\author{
January 1994
}

Energy Information Administration

Office of Coal, Nuclear, Electric and Alternate Fuels

U.S. Department of Energy

Washington, DC 20585

This report was prepared by the Energy Information Administration, the indepe ident statistical and analytical agency within the Department of Energy. The inforniation contained herein should not be construed as advocating or reflecting any policy position of the Department of Energy or cf any other organization. 


\section{Contacts}

This report was prepared in the Supply Analysis Branch, Analysis and Systems Division, Office of Coal, Nuclear, Electric and Alternate Fuels. General information regarding this publication may be obtained from John Geidl, Director, Office of Coal, Nuclear, Electric and Alternate Fuels (202/254-5570); Robert M. Schnapp, Director, Analysis and Systems Division (202/254-5392); Betsy O'Brien, Chief, Supply Analysis
Branch (202/254-5490); or B. D. Hong, (202/254-5365). Specific questions regarding the preparation and content of the report should be directed to Eugene R. Slatick (202/254-5384). Questions on current coal and other energy statistics should be directed to the National Energy Information Center (NEIC) (202/5868800). 


\section{Preface}

Section 205 (a)(2) of the Department of Energy Organization Act of 1977 (Public Law 95-91) requires the Administrator of the Energy Information Administration (EIA) to carry out a central, comprehensive, and unified energy data and information program that will collect, evaluate, assemble, analyze, and disseminate data and information relevant to energy resources, reserves, and related economic and statistical information.

As part of EIA's program to provide information on coal, this report, State Coal Profiles, summarizes basic information on the coal deposits, the development of the coal industry, and the use of coal in each of the 27 States with coal production in 1992. This information should serve as the basis for more detailed analyses of the role an individual State's coal resources and cosl industry have in contributing to the Nation's coal requirements.

The legislation that created EIA vested the organization with an element of statutory independence. EIA does not take positions on policy questions. EIA's responsibility is to provide timely, high-quality information and to perform objective, credible analyses. 


\section{Contents}

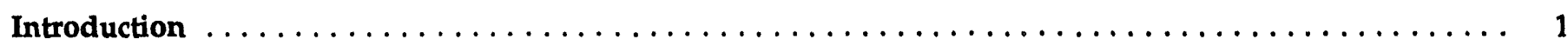

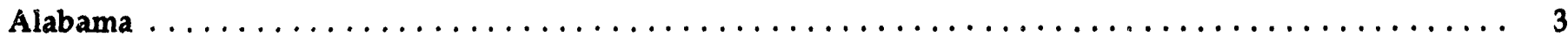

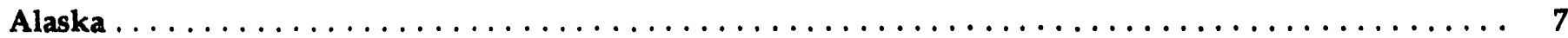

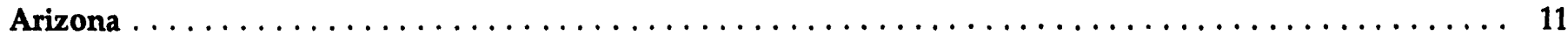

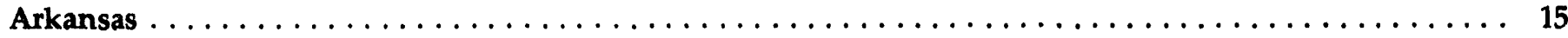

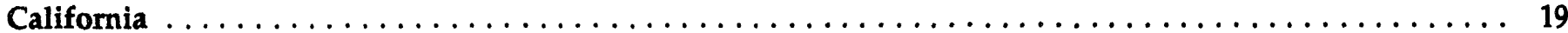

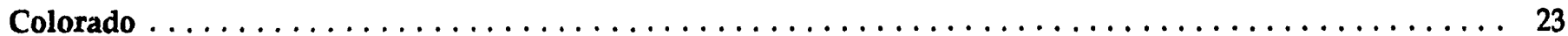

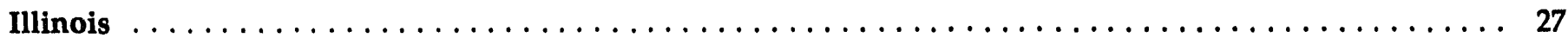

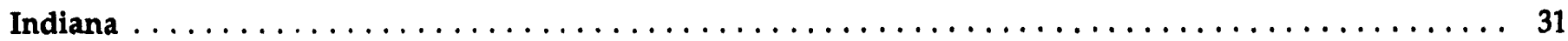

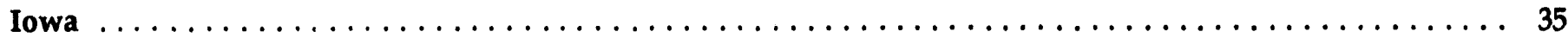

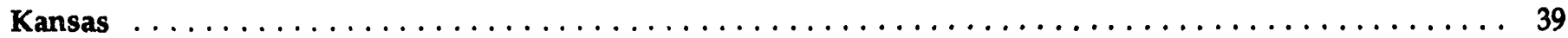

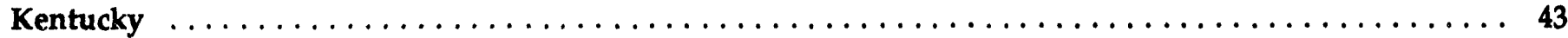

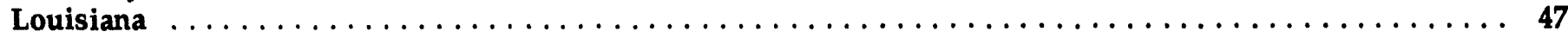

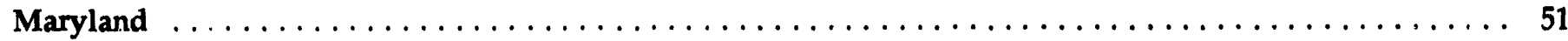

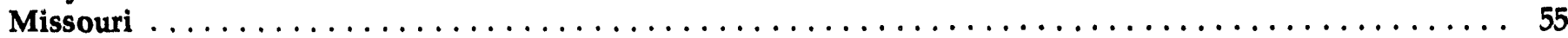

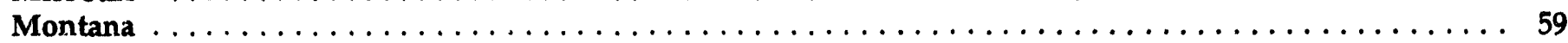

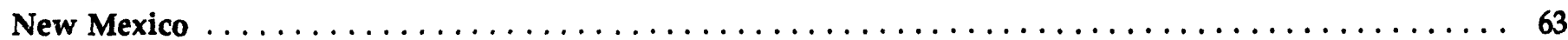

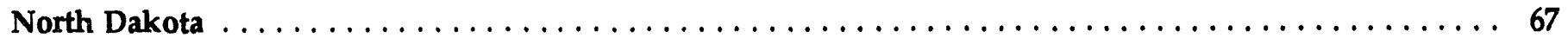

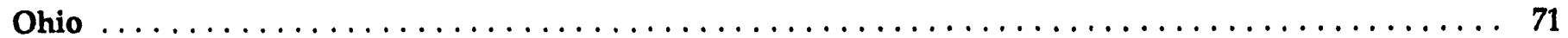

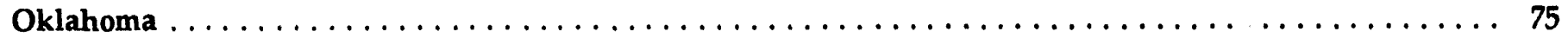

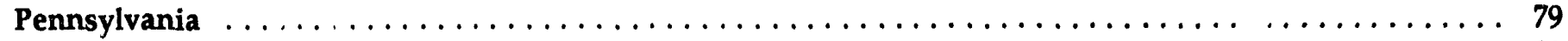

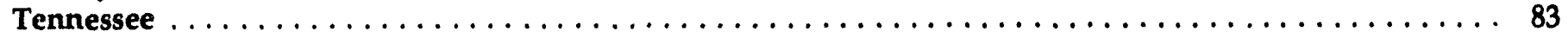

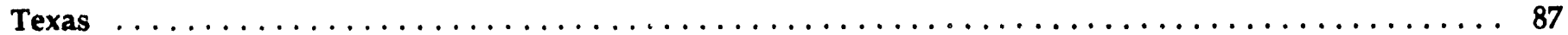

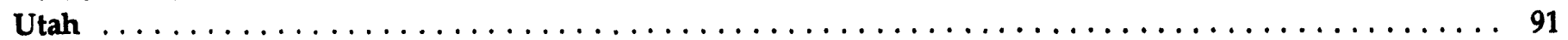

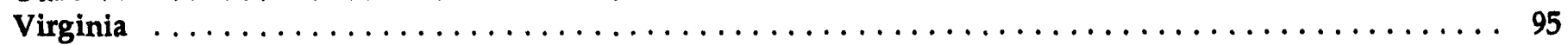

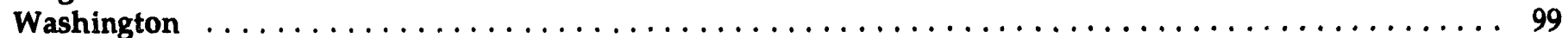

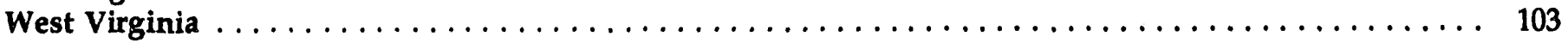

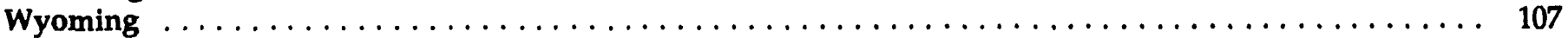

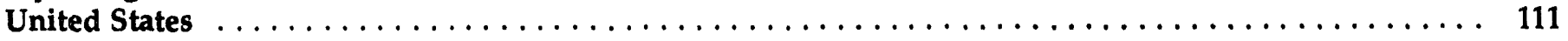

References $\ldots \ldots \ldots \ldots \ldots \ldots \ldots \ldots \ldots \ldots \ldots \ldots \ldots \ldots \ldots \ldots \ldots \ldots \ldots \ldots \ldots \ldots \ldots \ldots$

Appendices

A. National Rankings of Coal-Producing States and Percent of U.S. Total, $1992 \ldots \ldots \ldots \ldots \ldots \ldots$

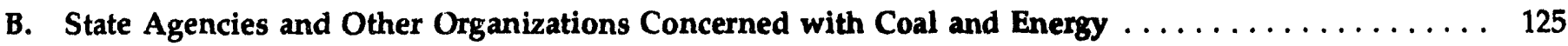

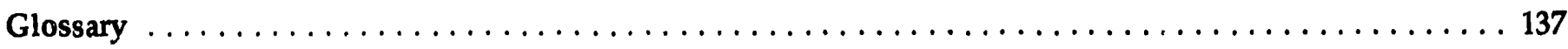




\section{Introduction}

The purpose of State Coal Profiles is to provide basic information about the deposits, production, and use of coal in each of the 27 States with coal production in 1992. Although considerable information on coal has been published on a national level, there is a lack of a uniform overview for the individual States. This report is intended to help fill that gap and also to serve as a framework for more detailed studies. While focusing on coal output, State Coal Profiles shows that the coalproducing States are major users of coal, together accounting for about three-fourths of total U.S. coal consumption in 1992.

At one time or another, coal has been produced in nearly all of the 38 States with coal deposits. Historically, this production played an important role in the development of these States as well as in the Nation's growth and westward expansion. U.S. coal production has reached record levels, but not all coalproducing States have shared in this growth. The peak years of coal production in some States occurred many decades ago, whereas in other States the coal industry has been revitalized in recent times. These changes reflect shifts in the use of coal over the years.

In the past, coal had a variety of uses. Large amounts were consumed for domestic heating, railroad fuel, as a source of heat for industrial processes, and as a source of coke for smelting iron ore for the iron and steel industry. Today, due to competition from other fuels and other sources of energy, coal is used mostly to generate electricity. Concern over environmental quality and the enactment of clean air legislation has led to the greater use of low-sulfur coal. This adversely affected production in States with low-quality coal, but rejuvenated the coal industry in States with environmentally acceptable coal. Advances in the technology for burning coal cleanly and for using it in new ways, such as a source of chemicals, could create future opportunities for coal development in some States. ${ }^{1}$

Each coal-producing State is profiled with a description of its coal deposits and a discussion of the development of its coal industry. Estimates of coal reserves in 1992 are categorized by mining method and sulfur content. Trends, patterns, and other information concerning production, number of mines, miners, productivity, mine price of coal, disposition, and consumption of coal are detailed in statistical tables for selected years from 1980 through 1992. In addition, coal's contribution to the State's estimated total energy consumption is given for 1991, the latest year for which data are available. A U.S. summary of all data is provided for comparing individual States with the Nation as a whole. Sources of information are given at the end of the tables.

Also included are a graph showing annual coal production in each State from 1890 through 1992 and three maps. The first map shows the coal-producing counties in 1992, the approximate locations of coal-fired power plants, coke plants, and coal gasification plants that were active during the year, and the approximate extent of coal-bearing areas. The other maps show, for 1992, the domestic distribution of coal produced in each State and the domestic origin of the coal shipped to each coal-producing State.

The appendices contain: (1) a table showing the 1992 national rankings of the coal-producing States for several categories of coal data, and (2) a list of addresses and telephone numbers of State agencies and other sources that can provide additional information about coal and current developments in each coalproducing State.

\footnotetext{
${ }^{1}$ The methane in coalbeds is produced commercially as an energy source in several States (e.g., Alabama, New Mexico, and Wyoming). Coalbed methane has become an important part of the U.S. reserves and production of natural gas, which is predominantly methane. A review of coalbed methane is beyond the scope of this report. For information, see "Coalbed Methane-State of the Industry," Quarterly Review of Methane from Coal Seams Technology 11, 1 (August 1993), pp. 1-52; Energy Information Administration, "Update on U.S. Coalbed Methane Production," Natural Gas Monthly October 1990, DOE/EIA-0130(90/10)(Washington, DC, December 1990), Pp.1-15; and "U.S. Coalbed Methane Production," Natural Gas Monthly January 1994, DOE/EIA-0130(94/01) (Washington, DC, January 1994), pp. 1-11.
} 


\section{State Coal Profile: Alabama}

Coal is the most important mineral commodity produced in Alabama, based on value of production. In 1992, the State's output of coal represented nearly onehalf of the total estimated value of all mineral commodities produced in the State, including crude oil and natural gas. Production from Federal coal leases generated nearly $\$ 1$ million in royalties, which were disbursed equally to the State and Federal Governments.

Large bituminous coal deposits occur in the northwestern part of the State. Lignite deposits, which are not mined, are scattered in the coastal plain in the South. The Warrior coalfield is the largest and most productive area. About 20 coalbeds are mined in the State, but most production is from the Blue Creek and Mary Lee coalbeds in the Warrior coalfield. These beds average 6 to 7 feet in thickness. Much of Alabama's coal can be converted into coke to make steel.

Commercial coal production in Alabama began around 1832 and was probably from outcrops in the Black Warrior River in Tuscaloosa County. The coal was transported by barge to Mobile and sold in competition with coal imported from England. The State's first large-scale underground mine, the Montevallo, was opened in Shelby County in 1856.

By about 1870, the development of the iron and steel industry in Birmingham provided the opportunity to mine large deposits of coking coal in the area. To satisfy the demand for coal for this and other domestic markets, including the railroads, Alabama's coal output rose from 8 million short tons at the turn of the century to 21 million short tons in 1926 before falling to less than half that amount during the Depression. Production during World War II increased to 19 million short tons.

Postwar production decreased as the pattern of coal use changed due to the dieselization of the railroads, competition from other fuels in the domestic market, and declining overseas markets. Production fell to about 10 million short tons in 1954 before beginning a generally upward trend. Initially supported by demand from the iron and steel industry, production is now largely sustained by the increased use of coal to generate electricity. Alabama's coal production was 26 million short tons in 1992.

Underground mines have generally been the major sources of Alabama's coal production. Several of these mines are among the deepest in the United States, producing from about 2,000 feet. In 1992, the State's largest coal producer, with more than 2 million short tons, was the Blue Creek No. 4 underground mine of Jim Walter Resources, Inc., in Tuscaloosa County. Tuscaloosa, Walker, and Jefferson were the leading coal-producing counties. About 1 percent of Alabama's 1992 coal output was from Federal coal leases.

In 1992, about three-fourths of Alabama's coal production was distributed to domestic markets and nearly one-fourth was exported overseas. More than 90 percent of the coal produced for domestic use was consumed in Alabama. The State's coal consumption was 32 million short tons in 1992. Electric utilities have been Alabama's leading coal consumers since the 1960 's, and their share of total consumption has grown steadily. More than two-thirds of the utility coal received in 1992 was produced in the State, with most of the balance received from Kentucky. The largest coal-fired generating facility is the 2,690-megawatt James H. Miller, Jr., plant of Alabama Electric Power Company in Jefferson County. About half of the coking coal used in Alabama was produced in the State; West Virginia and Virginia supplied virtually all of the balance. More than half of the coai delivered to other industrial users was Alabama coal. The principal consumers in this sector were paper and pulp mills, cement and lime plants, and organic fiber manufacturers.

The Customs District of Mobile ranked fifth in the United States in coal exports in 1992, handling 7 million short tons, or 7 percent, of the U.S. total. Mobile is a shipping point for export coal produced in Alabama and other coal-producing States in the East. The coalloading terminals are the McDuffie Island Terminal and the Bulk Plant, both operated by Alabama State Docks Department. 


\section{Alabama}

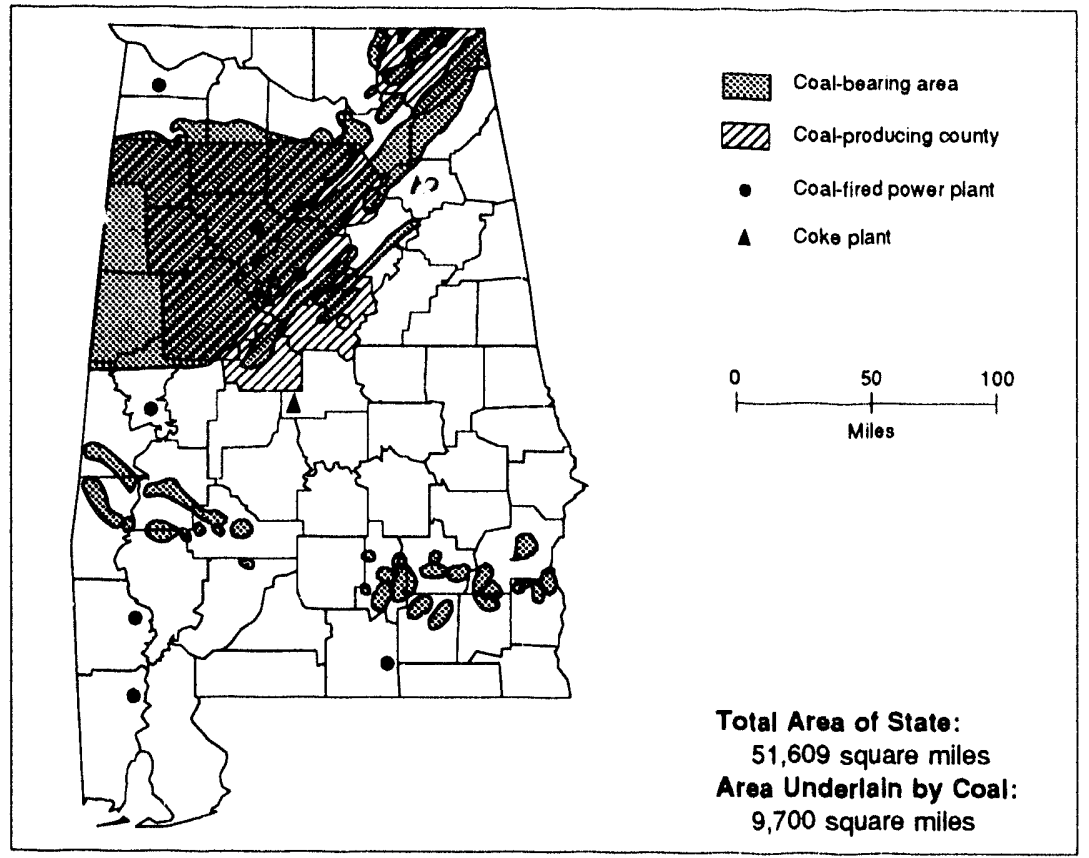

Coal Production, 1890-1992

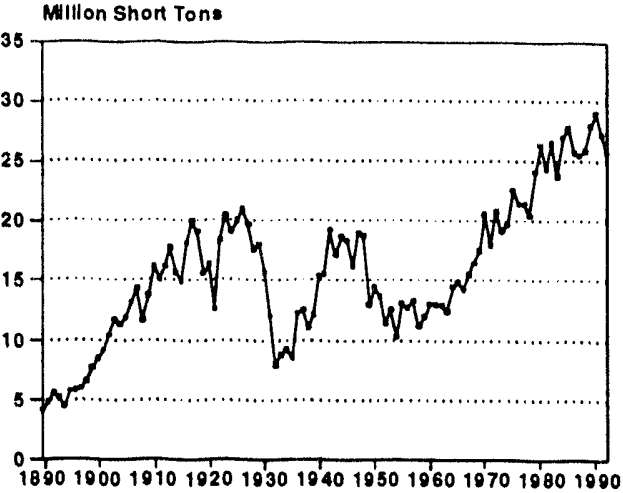

First Year of Documented Coal

Production ................ 1840 (946 short tons) Peak Year of Coal

Production . . . . . . . $1990(29,030,000$ short tons)

Coal Reserves (Million Short Tons)

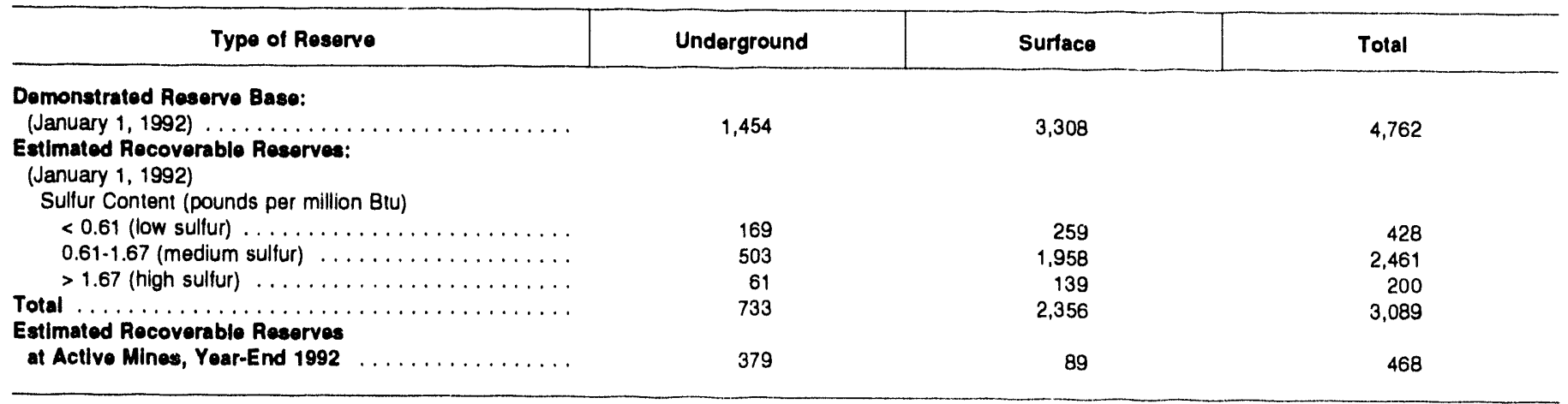

\section{Production}

\begin{tabular}{|c|c|c|c|c|c|}
\hline Sallent Data by Mine Type & 1980 & 1985 & 1990 & 1991 & 1992 \\
\hline \multicolumn{6}{|l|}{ Underground } \\
\hline Quantity (thousand short tons) $\ldots \ldots \ldots \ldots \ldots \ldots \ldots$ & 9,504 & 14,440 & 17,540 & 17,070 & 15,944 \\
\hline Mines $\ldots \ldots \ldots \ldots \ldots \ldots \ldots \ldots \ldots \ldots \ldots$ & 18 & 20 & 12 & 13 & 13 \\
\hline Miners $\ldots \ldots \ldots \ldots \ldots \ldots \ldots \ldots \ldots \ldots \ldots$ & 7.160 & 5,832 & 4,395 & 4,473 & 3,810 \\
\hline Productivity (short tons per miner per hour) $\ldots \ldots \ldots \ldots$ & .71 & 1.34 & 2.01 & 1.90 & 2.17 \\
\hline Average Mine Price (dollars per short ton) $\ldots \ldots \ldots \ldots \ldots$ & 43.37 & 44.22 & 42.48 & 40.19 & 40.70 \\
\hline \multicolumn{6}{|l|}{ Surface } \\
\hline Quantity (thousand short tons) $\ldots \ldots \ldots \ldots \ldots \ldots$ & 16,899 & 13,357 & 11,490 & 10,199 & 9,852 \\
\hline Mines $\ldots \ldots \ldots \ldots \ldots \ldots \ldots \ldots \ldots \ldots \ldots$ & 158 & 111 & 85 & 83 & 75 \\
\hline Miners $\ldots \ldots \ldots \ldots \ldots \ldots \ldots \ldots \ldots \ldots \ldots$ & 4.528 & 2,784 & 2,139 & 1,841 & 1,576 \\
\hline Productivity (short tons per miner per hour) $\ldots \ldots \ldots \ldots$ & 2.40 & 2.40 & 2.69 & 2.84 & 3.28 \\
\hline Average Mine Price (doliars per shon ton) $\ldots \ldots \ldots \ldots \ldots$ & 33.56 & 41.35 & 43.90 & 42.72 & 41.02 \\
\hline \multicolumn{6}{|l|}{ Tolal } \\
\hline Quantity (thousand short tons) $\ldots \ldots \ldots \ldots \ldots \ldots \ldots$ & 26,403 & 27,797 & 29,030 & 27,269 & 25,796 \\
\hline 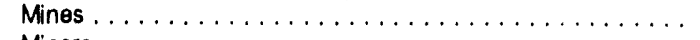 & 176 & 131 & 97 & 96 & 88 \\
\hline Miners $\ldots \ldots \ldots \ldots \ldots \ldots \ldots \ldots \ldots \ldots$ & 11,688 & 8,616 & 6,534 & 6,314 & 5,386 \\
\hline Productivity (short tons per miner per hour) $\ldots \ldots \ldots \ldots$ & 1.31 & 1.70 & 2.23 & 2.17 & 2.49 \\
\hline Average Mine Price (dollars per shon ton) $\ldots \ldots \ldots \ldots \ldots$ & 37.01 & 42.84 & 43.04 & 41.14 & 40.82 \\
\hline
\end{tabular}




\section{Alabama}

Number of Mines by Production Range and Percent of Production, 1992

\begin{tabular}{|c|c|c|c|c|c|c|c|c|}
\hline \multirow{2}{*}{ Mine Type } & \multicolumn{8}{|c|}{ Production Range (thousand short tons) } \\
\hline & Number & Percent & Number & Percent & Number & Percent & Number & Percent \\
\hline Underground & 8 & 94 & 1 & 5 & 0 & 0 & 4 & 1 \\
\hline Surface .... & 0 & 0 & 5 & 43 & 22 & 42 & 48 & 15 \\
\hline All Mines $\ldots \ldots \ldots \ldots$ & 8 & 58 & 6 & 19 & 22 & 16 & 52 & 7 \\
\hline
\end{tabular}

\section{Coal Demand}

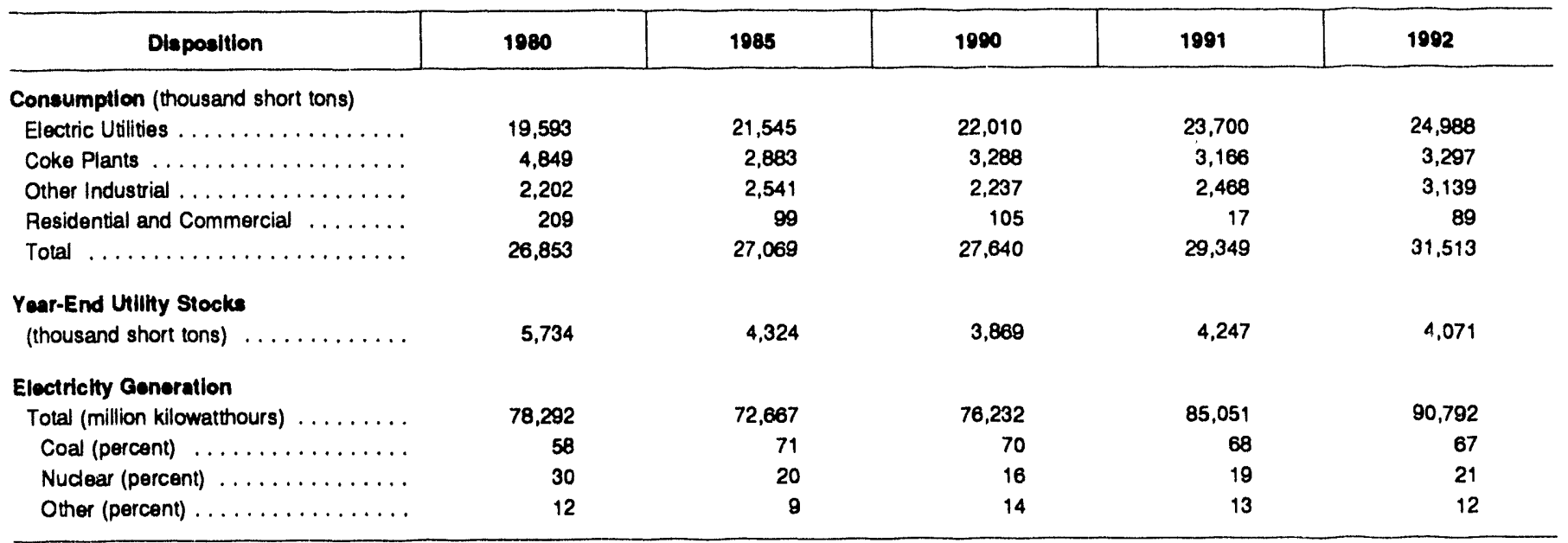

\section{Utility Coal Data, 1992}

\begin{tabular}{|c|c|c|}
\hline Average Qualty and Average Delivered Cost & Produced in State & Reculpte, All Sources \\
\hline Heat Content (million Btu per short ton) $\ldots \ldots \ldots \ldots \ldots \ldots$ & 24.19 & 24.12 \\
\hline Sulfur Content (percent by weight) $\ldots \ldots \ldots \ldots \ldots \ldots \ldots \ldots$ & 1.26 & 1.43 \\
\hline Ash Content (percent by weight) $\ldots \ldots \ldots \ldots \ldots \ldots \ldots$ & 12.42 & 11.80 \\
\hline Pounds of Suthr per million Bru $\ldots \ldots \ldots \ldots \ldots \ldots \ldots$ & 1.04 & 1.19 \\
\hline Dollars per million Btu $\ldots \ldots \ldots \ldots \ldots \ldots \ldots \ldots \ldots$ & 1.96 & 1.73 \\
\hline Dollars per short ton $\ldots \ldots \ldots \ldots \ldots \ldots \ldots \ldots \ldots$ & 47.35 & 41.67 \\
\hline
\end{tabular}

Estimated Total State Energy Cor umption, 1991: 1,591 trillion Btu (coal, 720; natural gas, 261; potroloum, 526; nuclear electric power, 171; hydroolectric power, 112; other, net interstate flow of electricity and associated losecs, -198 ).

Notes: Totals may not equal sum of components because of independent rounding. Data coverage-productlon: all mines. Number of mines: 1980, milies that produced 10,000 short tons or more; other years, all mines. Number of miners and productivity: mines that produced 10,000 or more short tons and preparation plants that had 5,000 or more employee hours. Average mine price: mines that produced 10,000 or more short tons. Average quality and average dellvered cost of utility coal: power plants with a generator nameplate capacity of 50 megawatts or more. Extent of coal-bearing areas and locations of coalconsuming plants shown on map are approximate; small coal deposits are not shown. Coal-producing counties shown on map exclude any county where all 1992 output was from mines producing less than 10,000 short tons.

Sources: Energy Information Administration-U.S. Coal Reserves: An Update by Heat and Sulfur Content, February 1993 ; Coal Production 1992 and prior issues; Coal Data: A Reference; Quarterly Coal Report October-December 1992 and prior issues; Electric Power Annual 1991 and prior issues; Electric Power Monthly. March 1993; Cost and Quality of Fuels for Electric Power Plants 1992; Inventory of Power Plants in the United States 1992; State Energy Data Report 1991: Consumption Estimates; Map of coal-bearing areas is based mainly on U.S. Geological Survey map. Coalfields of the United States, 1960. Data for historical graph 1890-1975, U.S. Department of the Interior, Geological Survey and Bureau of Mines (Minerals Yearbook and annual predecessor Mineral Resources of the United States); 1976 forward, Energy Information Administration, Coal Production 1992 and prior issues. 
Destination of Coal Produced in Alabama, 1992

(Million Short Tons)

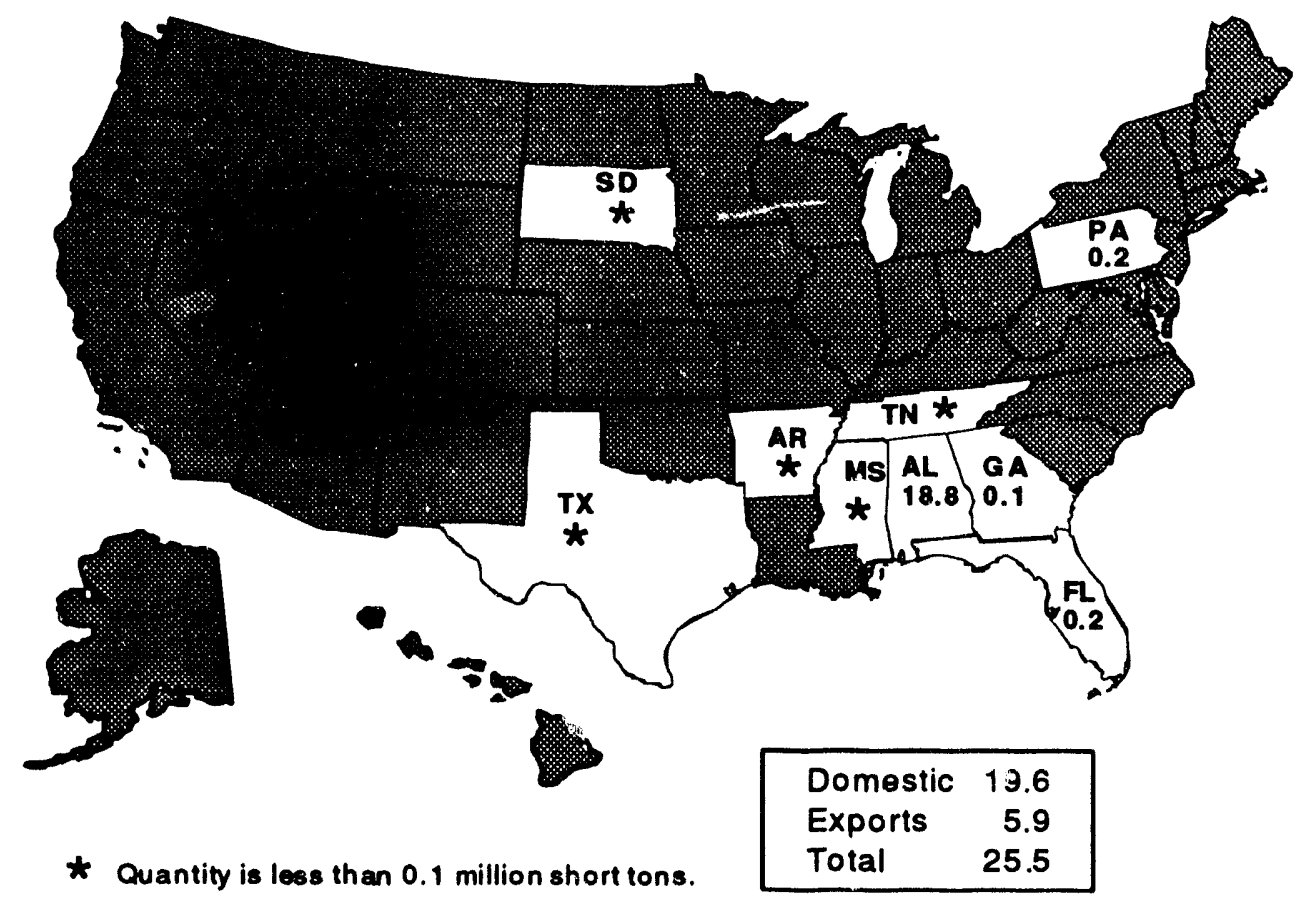

Transportation modes to domestic markets (percent): rail, 33; water, 12; truck, 45; tramway/conveyor, 9; unknown 1.

Note: Total may not equal sum of components because of independent rounding.

Source: Energy Information Administration, Form EIA-6, "Coal Distribution Report."

Origin of Coal Recelved in Alabama, 1992

(Million Short Tons)

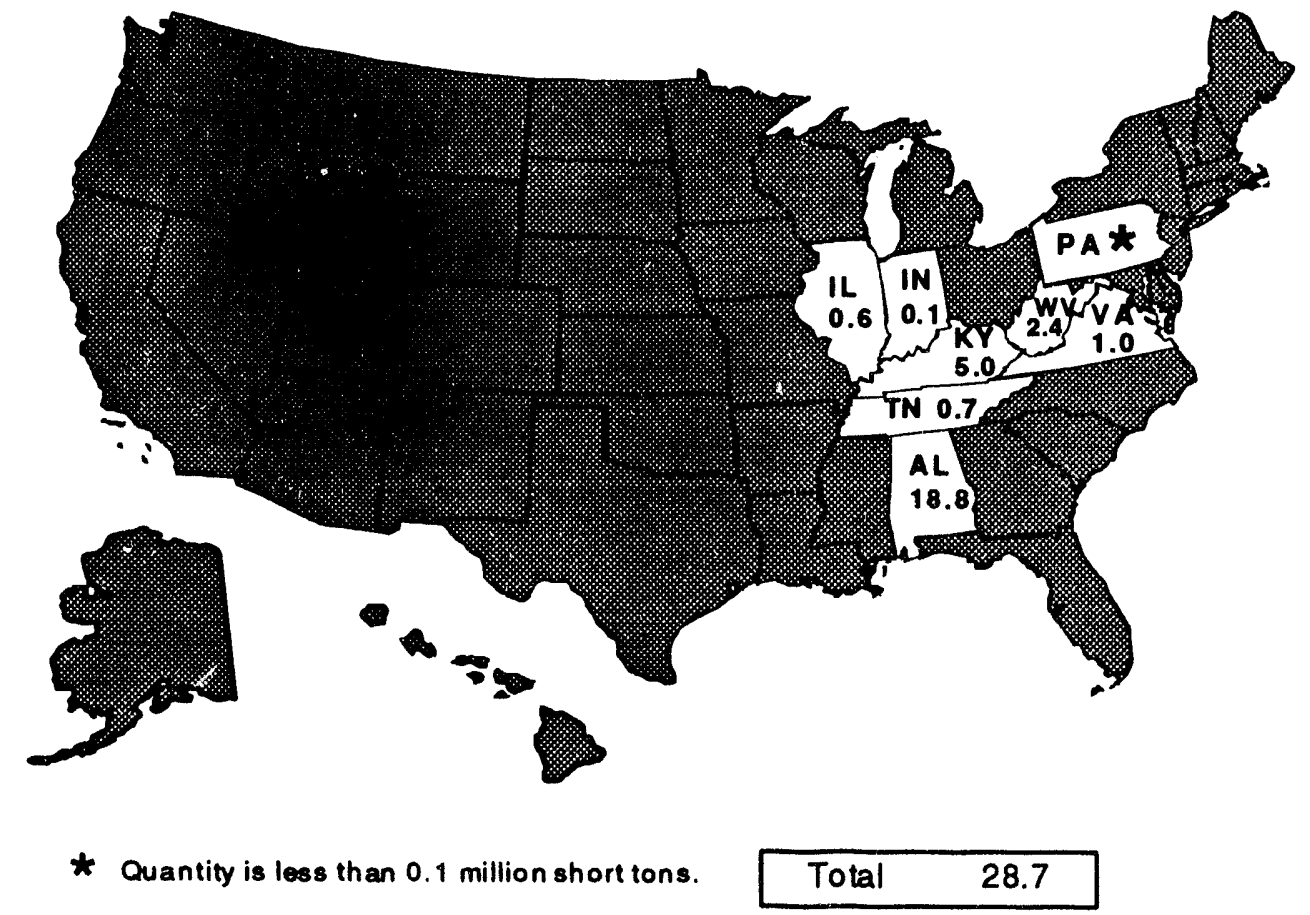

Note: Total may not equal sum of components because of independent rounding.

Source: Energy Information Administration, Form EIA-6, "Coal Distribution Report." 


\section{State Coal Profile: Alaska}

Alaska has an extensive reser re base of coal, but very little of it has been developed because of competition from the petroleum and natural gas produced in the State. Currently, only one surface mine actively produces coal in the State, and about half of its annual output of 1.5 million short tons is exported. ${ }^{1}$ The value of coal production to the economy of Alaska is also small. In 1992, coal was estimated to account for less than 1 percent of the total value of all mineral commodities produced in the State, including crude oil and natural gas.

Coal mining in Alaska began on a commercial scale in 1855, while the area was still a Russian territory. A mine was developed near Port Graham, on the Kenai Peninsula, with the hope of exporting coal to California. Unable to compete in the export market, the mine instead supplied coal to steamers, whaling ships, and local consumers for about 10 years. After Alaska was purchased by the United States, in 1867, many small mines were opened to provide coal for riverboats, domestic heating, and thawing frozen ground for gold mining. Production at the turn of the century was about 3,000 short tons per year. This represented about 3 percent of the total coal consumed in Alaska. Canada and Washington State supplied most of the rest.

In the early 1900 's, coal production trended upward as mines were opened near Anchorage and Healy to supply coal for the U.S. Navy, for developments at Anchorage and Fairbanks, and for the Alaska Railroad. In addition to consuming coal, the Alaska Railroad played an important role in opening up coal markets along its route.

Production rose from about 100,000 short tons in the late 1920's to more than 700,000 short tons in the 1950's. During and after World War II, the military buildup near Anchorage and Fairbanks expanded markets for coal. In the postwar period, markets were lost and mines closed when the Alaska Railroad converted to diesel-electric locomotives, and when oil and natural gas produced from large deposits discovered in the Cook Inlet captured most of the coal market in the Anchorage area. Afterward, coal production fluctuated from 600,000 to 900,000 short tons until 1985 , when it rose sharply to 1.4 million short tons with the beginning of exports to Korea.

Since the early 1970's, the only active coal mine in Alaska has been operated by Usibelli Coal Mine, Inc., near Healy in the Nenana field, south of Fairbanks. Several other coal mines are planned in Alaska, pending an expansion of Alaska coal exports to the Acian market.

The Usibelli mine produces subbituminous coal mainly from three beds that range from 18 to nearly 30 feet in thickness. Overburden is removed by a dragline that reportedly is the largest land-based machine in Alaska. Coal is transported from the mine by the Alaska Railroad. As mined, Usibelli coal averages 15.6 million Btu per short ton, 0.2 percent sulfur (by weight), and 8.1 percent ash.

Usibelli's domestic customers include a minemouth power plant at Healy, and cogeneration power plants, which supply both electricity and steam for heating, that are operated by the Fairbanks Municipal Utilities System, the University of Alaska Fairbanks, and military bases near Fairbanks. The State's largest coalfired electric generating facilities are the 28-megawatt Chena plant, operated by the City of Fairbanks, and the 27-megawatt Healy plant, operated by Golden Valley Electric Association. Small amounts of coal are also used for heating residences and schools in the Healy and Fairbanks areas. Usibelli exports coal to the Korean Electric Power Company. The export coal is transported on the Alaska Railroad about $\mathbf{3 0 0}$ miles to Seward, a year-round ice-free port.

${ }^{1}$ In 1992, Arctic Slope Consulting Group was developing a coal mine in the Deadfall Syncline area, near Kotzebue; production was less than 1,000 short tons. 


\section{Alaska}

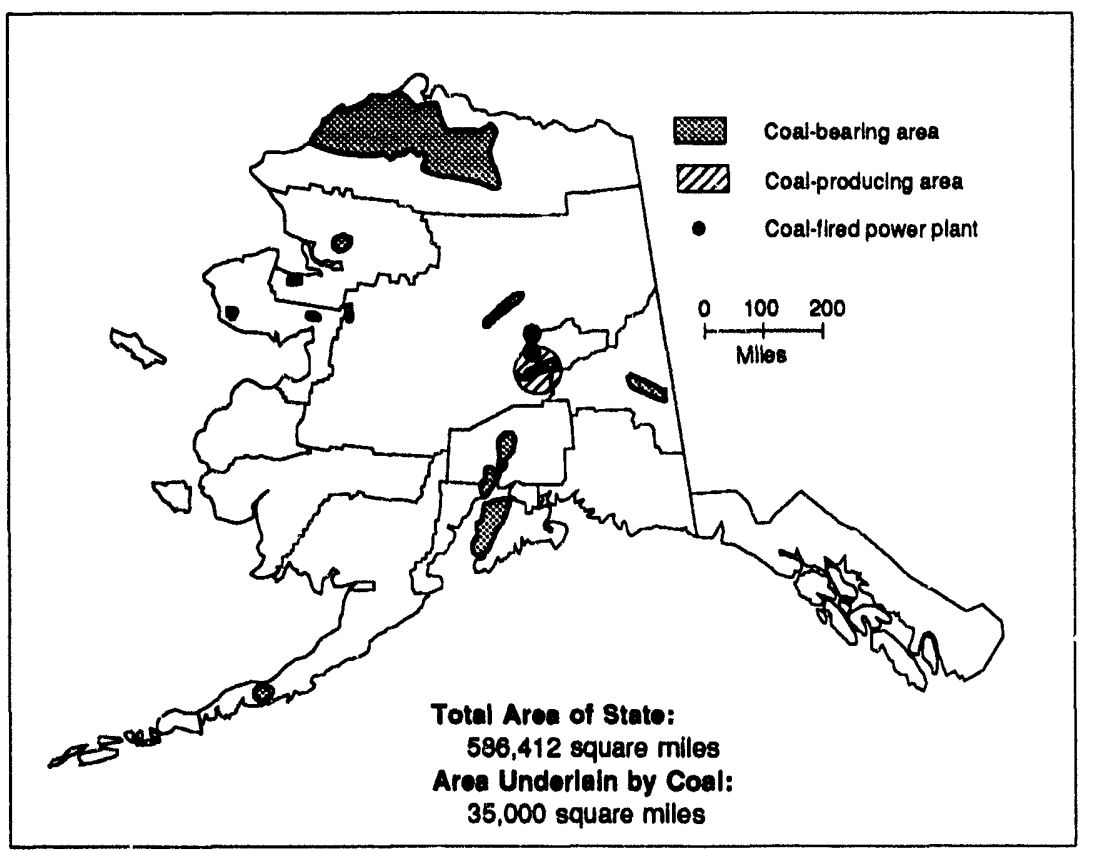

Coal Production, 1890-1992

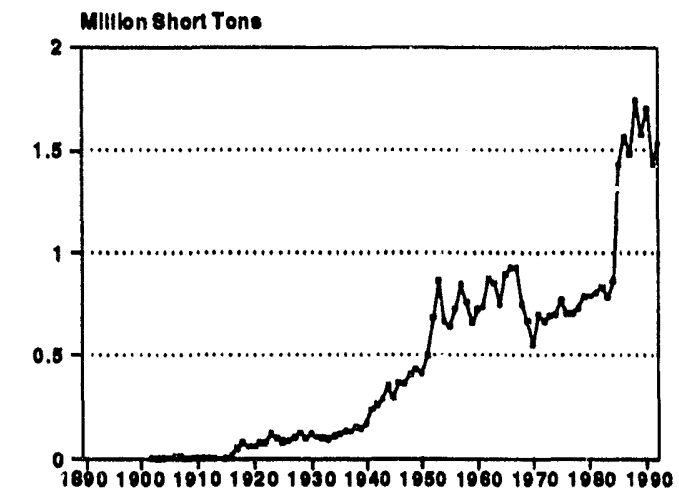

Firet Year of Documonted Coal

Production . . . . . . . . . . . . . . . 1897 (2,000 short tons) Poak Yoar of Coal

Production $1988(1,745,000$ short tone $)$

\section{Coal Reserves (Million Short Tons)}

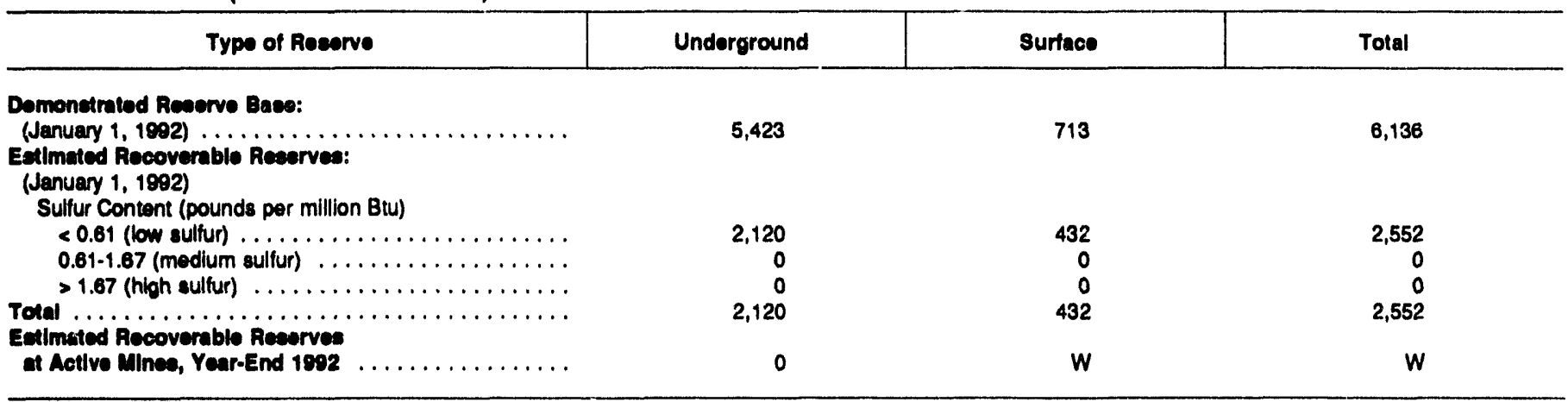

\section{Production}

\begin{tabular}{|c|c|c|c|c|c|}
\hline Ballont Data by Mine Type & 1980 & 1085 & 1980 & 1991 & 1992 \\
\hline \multicolumn{6}{|l|}{ Underground } \\
\hline Quantity (thousand short tons) $\ldots \ldots \ldots \ldots \ldots \ldots \ldots$ & 0 & 0 & 0 & 0 & 0 \\
\hline 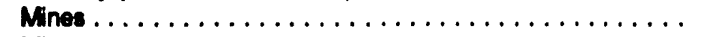 & 0 & 0 & 0 & 0 & 0 \\
\hline 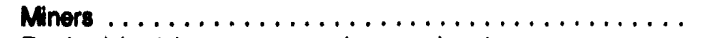 & 0 & 0 & 0 & 0 & 0 \\
\hline Productvity (short tans per miner per hour) $\ldots \ldots \ldots \ldots$ & $\cdots$ & $\cdot \cdot$ & $\cdots$ & $\cdots$ & $\cdots$ \\
\hline Averege Mine Price (dollars per short ton) $\ldots \ldots \ldots \ldots \ldots$ & -- & $\cdots$ & -- & -- & $\cdots$ \\
\hline \multicolumn{6}{|l|}{ Surtece } \\
\hline Quantity (thousand short tons) $\ldots \ldots \ldots \ldots \ldots \ldots \ldots$ & 791 & 1,433 & 1,706 & 1,436 & 1,534 \\
\hline 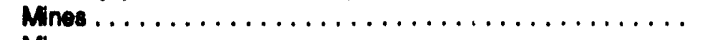 & 1 & 1 & 1 & 1 & $2^{a}$ \\
\hline Miners $\ldots \ldots \ldots \ldots \ldots \ldots \ldots \ldots \ldots \ldots \ldots \ldots \ldots$ & 33 & 96 & 84 & 99 & 111 \\
\hline Productivity (short tons per miner per hour) $\ldots \ldots \ldots \ldots$ & 6.12 & 6.20 & 8.46 & 6.82 & 6.93 \\
\hline Average Mine Price (dollars per short ton) $\ldots \ldots \ldots \ldots \ldots$ & W & $W$ & $W$ & $W$ & W \\
\hline \multicolumn{6}{|l|}{ Totel } \\
\hline Quantity (thousand short tons) & 791 & 1,433 & 1,706 & 1,436 & 1,534 \\
\hline 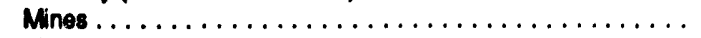 & 1 & 1 & 1 & 1 & 2 \\
\hline 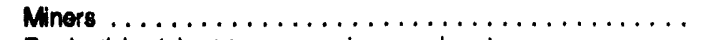 & 33 & 96 & 84 & 99 & 111 \\
\hline Productivity (short tons per miner per hour) $\ldots \ldots \ldots \ldots$ & 6.12 & 6.20 & 8.46 & 6.82 & 6.93 \\
\hline Average Mine Price (dollars per short ton) $\ldots . \ldots \ldots \ldots$. . . & W & $\mathbf{W}$ & W & $W$ & W \\
\hline
\end{tabular}




\section{Alaska}

Number of Mines by Production Range and Percent of Production, 1992

\begin{tabular}{|c|c|c|c|c|c|c|c|c|}
\hline \multirow{2}{*}{ Mins Type } & \multicolumn{8}{|c|}{ Production Range (thousand short tons) } \\
\hline & Number & Percent & Number & Percent & Number & Percent & Number & Percent \\
\hline Underground & 0 & 0 & 0 & 0 & 0 & 0 & 0 & 0 \\
\hline Surfaco $\ldots \ldots \ldots \ldots \ldots \ldots \ldots \ldots \ldots \ldots$ & 1 & 100 & 0 & 0 & 0 & 0 & 1 & $<1$ \\
\hline All Mines $\ldots \ldots \ldots \ldots \ldots \ldots \ldots \ldots \ldots$ & 1 & 100 & 0 & 0 & 0 & 0 & 1 & $<1$ \\
\hline
\end{tabular}

\section{Coal Demand}

\begin{tabular}{|c|c|c|c|c|c|}
\hline Disposition & 1960 & 1965 & 1990 & 1991 & 1992 \\
\hline \multicolumn{6}{|l|}{ Consumption (thousand short tons) } \\
\hline Electric Utillies . . . . . . . . . . . & 272 & 296 & 290 & 298 & 287 \\
\hline Coke Plants $\ldots \ldots \ldots \ldots \ldots \ldots$ & 0 & 0 & 0 & 0 & 0 \\
\hline Other Industrial $\ldots \ldots \ldots \ldots \ldots \ldots$ & 0 & w & 0 & 0 & 0 \\
\hline Residential and Commercial $\ldots \ldots \ldots$ & 0 & w & 494 & 504 & 514 \\
\hline Total $\ldots \ldots \ldots \ldots \ldots \ldots \ldots$ & 272 & 733 & 784 & 802 & 782 \\
\hline \multicolumn{6}{|l|}{ Year-End Uillity Srocks } \\
\hline (thousand short tons) & 5 & 2 & 2 & 8 & 6 \\
\hline \multicolumn{6}{|l|}{ Electrichy Generation } \\
\hline Total (million kilowatthours) & 3,090 & 4,285 & 4,493 & 4,286 & 4,129 \\
\hline Cod (porcent) $\ldots \ldots \ldots \ldots \ldots$ & 10 & 7 & 7 & 8 & 7 \\
\hline Nuclear (percent) $\ldots \ldots \ldots \ldots \ldots$ & 0 & 0 & 0 & 0 & 0 \\
\hline Other (percent) $\ldots \ldots \ldots \ldots \ldots$ & 90 & 93 & 93 & 92 & 93 \\
\hline
\end{tabular}

Utility Coal Data, 1992

\begin{tabular}{|c|c|c|}
\hline Average Qualliy and Avorage Dellvered Cost & Produced in state & Recolpts, All Sources \\
\hline Heat Content (million Btu per short ton) $\ldots \ldots \ldots \ldots \ldots$ & -- & $\cdots$ \\
\hline Sulfur Content (percent by woight) . . . . . . . . . . . . & - & $\cdots$ \\
\hline Ash Content (percent by weight) $\ldots \ldots \ldots \ldots \ldots \ldots \ldots$ & - & $\cdots$ \\
\hline Pounds of Sulfur per million Btu $\ldots \ldots \ldots \ldots \ldots \ldots \ldots$ & $\because$ & $\cdots$ \\
\hline Dollars per million Btu . . . . . . . . . . . . . . . . . & $\cdots$ & $\cdots$ \\
\hline Dollars per short ton $\ldots \ldots \ldots \ldots \ldots \ldots \ldots \ldots \ldots$ & -- & $\cdots$ \\
\hline
\end{tabular}

Estimated Total State Energy Consumption, 1901 : 588 trillion Btu (coal, 13; natural gas, 368; potroleum, 198; nuclear electric power, 0; hydroelectric power, 9; othor, 0; not interstate flow of electriclty and assoclated losese, 0 ).

Includes one mine under development with a small output during part of the year.

$W=$ Withheld to avoid disclosure of individual company data.

Notes: Totals may not equal sum of components because of independent rounding. Date coverage-Production: all mines. Number of mines: 1980 , mines that produced 10,000 short tons or more; other years, all mines. Number of mirmers and productivity: mines that produced 10,000 or more short tons and preparation plants that had 5,000 or more employee hours. Average mine price: mines that produced 10,000 or more short tons. Average quality and average delivered cost of utility coal: power plants with a generator nameplate capacity of 50 megawatts or more. Extent of coal-bearing areas and locati is of coal-consuming plants shown on map are approximate; small coal deposits are not shown. Coal-producing counties shown on map exclude any county where all 1992 output was from mines producing less than 10,000 short tons.

Sources: Energy Information Administration-U.S. Coal Reserves: An Update by Heat ar.s Sulfur Content, February 1993 ; Coal Production 1992 and prior issues; Coal Data: A Reference; Quarterly Coal Report October-December 1992 and prior issues; Electric Power Annual 1991 and prior issues; Electric Power Monthly, March 1993; Cost and Quality of Fuels for Electric Power Plants 1992; Inventory of Power Plants in the United States $1992 ;$ State Energy Data Report 1991: Consumption Estimates; Map of coal-bearing areas is based mainly on U.S. Geological Survey map, Coalfields of the United States, 1960. Data for historical graph 1890-1975, U.S. Department of the Interior, Geological Survey and Bureau of Mines (Minorals Yearbook and annual predecessor Mineral Resources of the United States); 1976 fonward, Energy Information Administration, Coal Production 1992 and prior issues. 


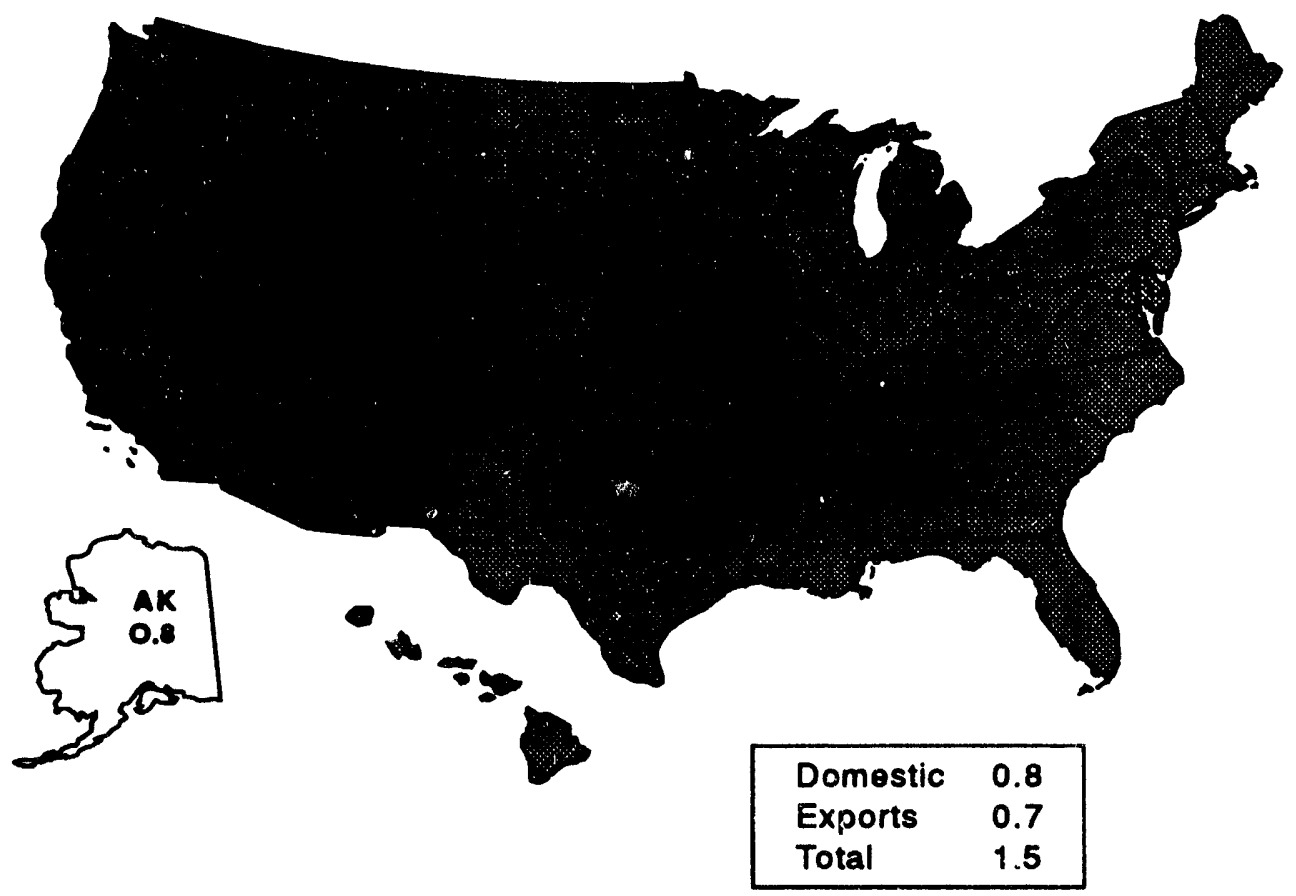

Transportation modes, domestic markets (percent): rail, 81; truck, 19.

Note: Total may not equal sum of components because of independent rounding.

Source: Energy Information Administration, Form EIA-6, "Coal Distribution Report."

\section{Origin of Coal Recolved in Alaska, 1992}

(Million Short Tons)

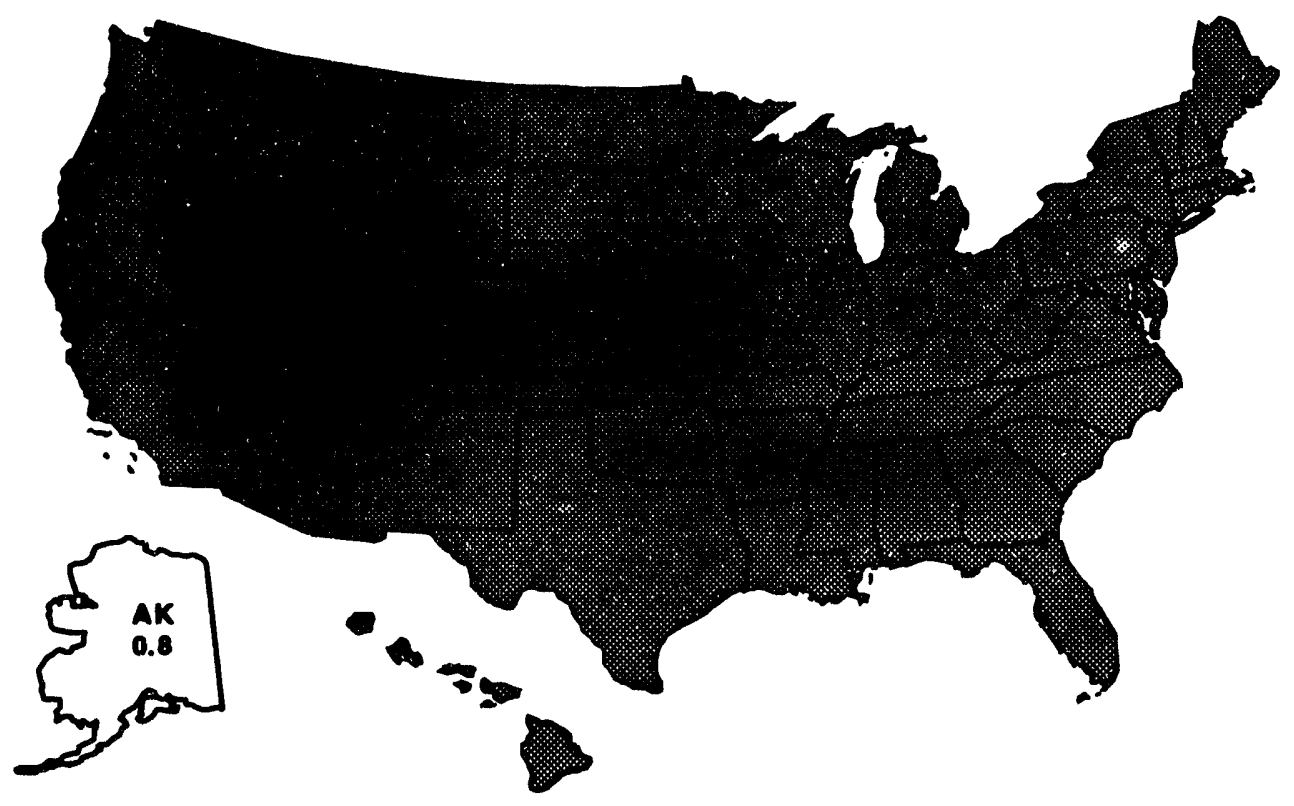

$$
\text { Total } 0.8
$$

Note: Total may not equal sum of components because of independent rounding.

Source: Energy Information Administration, Form EIA-6, "Coal Distribution Report." 


\section{State Coal Profile: Arizona}

Coal ranks a distant second in value to copper among the mineral commodities produced in Arizona. However, Arizona is notable as a source of coal because all production is from leases on Indian lands, and because the State has the only long-distance coal-slurry pipeline in the country. Indian royalties from coal sales in 1992 were $\$ 33$ million.

All of Arizona's coal production, which totaled about 13 million short tons in 1992, is from the Black Mesa field in the northeastern part of the State, in Navajo County. This is a plateau area covering more than 3,000 square miles of Indian land. Black Mesa coal is generally classified as bituminous coal.

Black Mesa coal is historically noteworthy because archeological evidence shows that prehistoric Indians used it for firing pottery at least as far back as 1300 A.D. Although the first official record of coal production in Arizona was in 1926, small amounts of coal were mined by settlers for local use in earlier years. Between 1926 and 1970, coal production was intermittent and usually amounted to less than 10,000 short tons per year, reflecting the remoteness of the coal deposits, a small population, and a lack of coal-based industries. Most of the coal was produced for heating schools on the Navajo Indian Reservation.

After 1970 the output of coal in Arizona increased markedly. This was due to the opening of two large surface mines in Black Mesa field-Black Mesa and Kayenta-to produce coal for two large power plants built to help meet the growing demand for electricity in southern California and the Southwest. Peabody Coal Company developed and continues to operate both mines, located about 16 miles apart, on about 65,000 acres of land leased from the Navajo and Hopi Indian tribes. Production is from four to five coalbeds that range from 3 to 10 feet in thickness. Both mines rank among the largest U.S. codl mines.

Black Mesa supplies coal to the 1,580-megawatt Mohave power plant of Southern California Edison Company, in southeastern Nevada. The transportation link between the mine and power plant is unique: coal is delivered as a slurry through a 273-mile long, 18-inch pipeline. The coal slurry (a mixture of half finely ground coal and half water, by weight) is pumped at a rate of about 3.5 miles per hour. Kayenta produces coal for the 2,250-megawatt Navajo power plant, located near Page, in Coconino County, and operated by the Salt River Project Agricultural Improvement and Power District. Coal from the mine is hauled to the power plant on an 83-mile-long private railroad. A 17-mile long conveyor connects the mine with the railroad.

Less than half of the 18 million short tons of coal consumed in Arizona in 1992 was produced in the State. Electric utilities were the principal consumers. Except for the Navajo power plant, the utilities consumed coal received primarily from New Mexico. Other coal consumers in Arizona were chiefly cement plants and a paperboard mill. 


\section{Arizona}
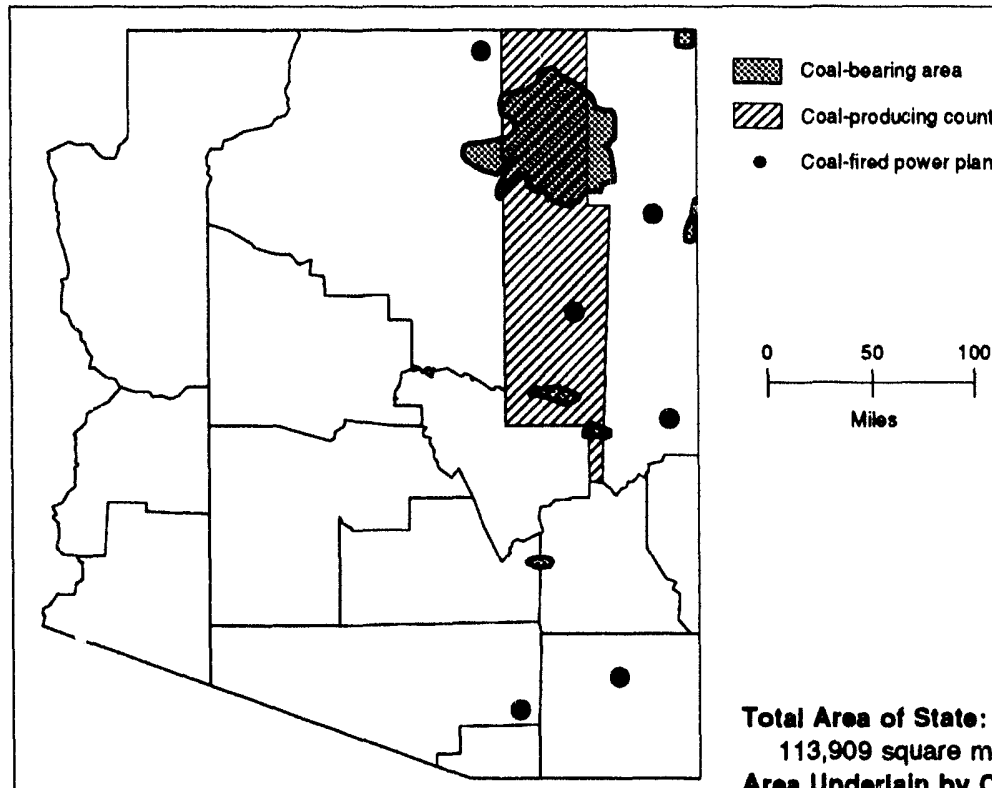

Total Area of State:

113,909 square miles

Area Undorlain by Coal:

3,040 square miles
Coal Production, 1890-1992

Million Short Tons

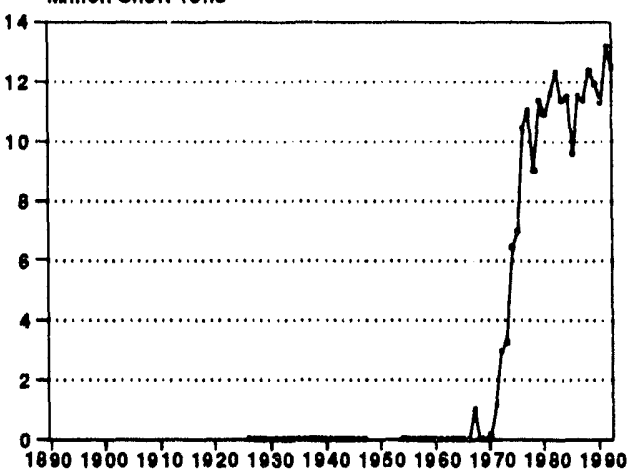

First Year of Documented Coal

Production . . . . . . . . . . . . . . 1926 (624 short tons) Peak Year of Coal

Production

Coal Reseryes (Million Short Tons)

\begin{tabular}{|c|c|c|c|}
\hline Type of Reserve & Underground & Surface & Total \\
\hline \multicolumn{4}{|l|}{ Demonotrated Reservo Base: } \\
\hline (January 1,1992$) \ldots \ldots \ldots$ & 102 & 135 & 236 \\
\hline$<0.61$ (low sulfur) $\ldots \ldots \ldots \ldots \ldots$ & 51 & 106 & 158 \\
\hline $0.61-1.67$ (medium sulfur) $\ldots \ldots \ldots \ldots \ldots \ldots \ldots \ldots$ & 0 & 0 & 0 \\
\hline $\begin{array}{l}\text { Estimated Recoverable Recerves } \\
\text { it Active Mines, Year-End } 1992\end{array}$ & & & \\
\hline at Active Mines, Year-End 1992 & 0 & W & w \\
\hline
\end{tabular}

\section{Production}

\begin{tabular}{|c|c|c|c|c|c|}
\hline Sallent Data by Mine Typo & 1980 & 1985 & 1990 & 1991 & 1992 \\
\hline \multicolumn{6}{|l|}{ Underground } \\
\hline Quantity (thousand short tons) $\ldots \ldots \ldots \ldots \ldots \ldots$ & 0 & 0 & 0 & 0 & 0 \\
\hline 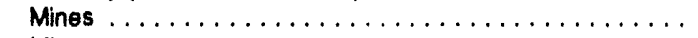 & 0 & 0 & 0 & 0 & 0 \\
\hline 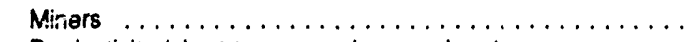 & 0 & 0 & 0 & 0 & 0 \\
\hline Productivity (short tons per miner per hour) $\ldots \ldots \ldots \ldots$ & $-\cdot$ & -- & $-\cdot$ & .. & -- \\
\hline Average Mine Price (dollars per short ton) . . . . . . . . & -. & -- & -. & $-\cdot$ & -. \\
\hline \multicolumn{6}{|l|}{ Surface } \\
\hline Quantity (thousand short tons) $\ldots \ldots \ldots \ldots \ldots \ldots$ & 10,905 & 9,625 & 11,304 & 13,203 & 12,512 \\
\hline 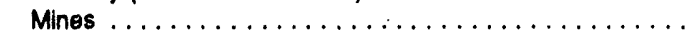 & 2 & 2 & 2 & 2 & 2 \\
\hline 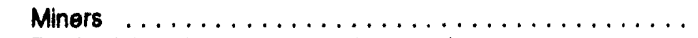 & 897 & 885 & 951 & 900 & 888 \\
\hline Productivity (short tons per miner per hour) $\ldots \ldots \ldots \ldots$ & 5.29 & 6.53 & 5.93 & 6.64 & 6.29 \\
\hline Average Mine Price (dollars per short ton) $\ldots \ldots \ldots \ldots \ldots$ & W & W & W & W & W \\
\hline \multicolumn{6}{|l|}{ Total } \\
\hline Quantity (thousand short tons) & 10,905 & 9,625 & 11,304 & 13,203 & 12,512 \\
\hline 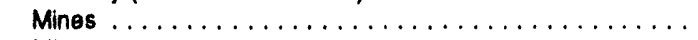 & 2 & 2 & 2 & 2 & 2 \\
\hline Miners $\ldots \ldots \ldots \ldots \ldots \ldots \ldots \ldots$ & 897 & 885 & 951 & 900 & 888 \\
\hline Productivity (shon tons per miner hour) $\ldots \ldots \ldots \ldots$ & 5.29 & 6.53 & 5.93 & 6.64 & 6.29 \\
\hline Average Mine Price (dollars per short ton) . . . . . . . . & W & W & $w$ & $W$ & $W$ \\
\hline
\end{tabular}




\section{Arizona}

Number of Mines by Production Range and Percent of Production, 1992

\begin{tabular}{|c|c|c|c|c|c|c|c|c|}
\hline \multirow{3}{*}{ Mine Type } & \multicolumn{8}{|c|}{ Production Range (thousand short tons) } \\
\hline & \multicolumn{2}{|c|}{1,000 and over } & \multicolumn{2}{|c|}{500 to 999} & \multicolumn{2}{|c|}{100 to 499} & \multicolumn{2}{|c|}{$<100$} \\
\hline & Number & Percent & Number & Percent & Number & Percent & Number & Percent \\
\hline Underground & 0 & 0 & 0 & 0 & 0 & 0 & 0 & 0 \\
\hline Surface ... & 2 & 100 & 0 & 0 & 0 & 0 & 0 & 0 \\
\hline All Mines & 2 & 100 & 0 & 0 & 0 & 0 & 0 & 0 \\
\hline
\end{tabular}

Coal Demand

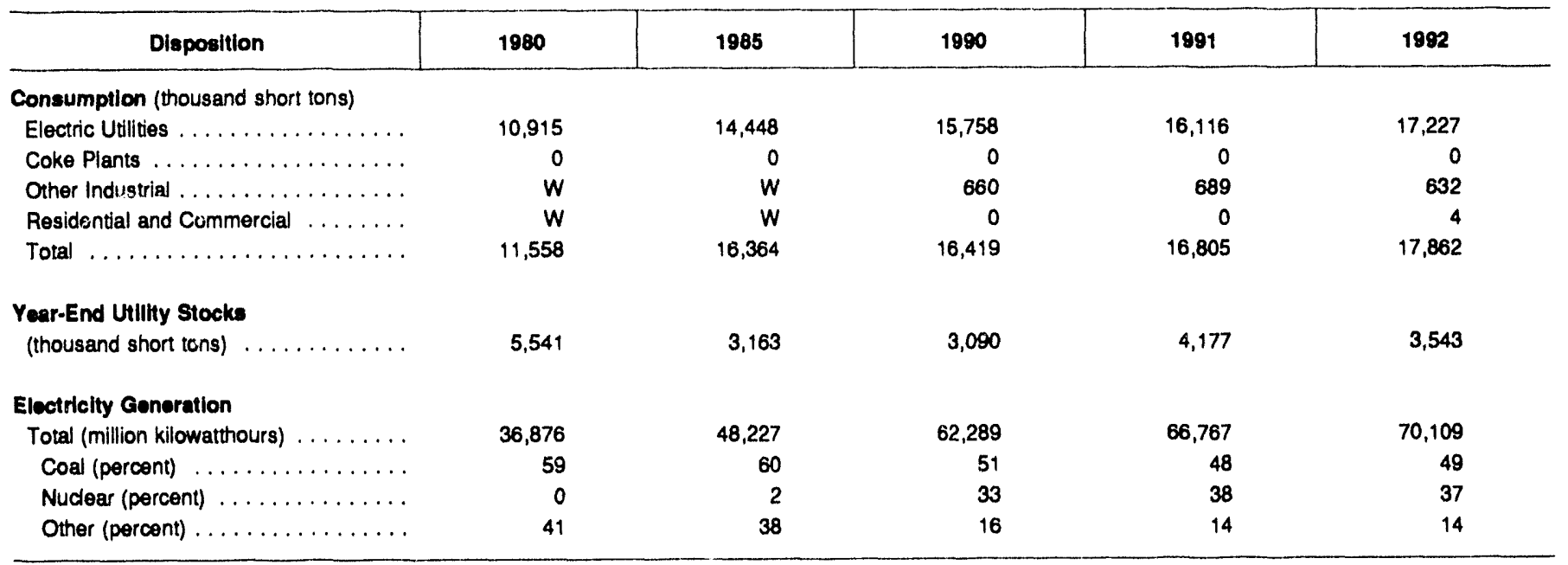

\section{Utility Coal Data, 1992}

\begin{tabular}{|c|c|c|}
\hline Average Quality and Average Dellvered Cost & Produced In State & Receipts, All Sources \\
\hline Heat Content (million Btu per short ton) $\ldots \ldots \ldots \ldots \ldots \ldots$ & 22.00 & 20.61 \\
\hline Sulfur Content (percent by woight) $\ldots \ldots \ldots \ldots \ldots \ldots \ldots$ & .52 & .51 \\
\hline Ash Content (percent by woight) $\ldots \ldots \ldots \ldots \ldots \ldots \ldots$ & 9.50 & 12.19 \\
\hline Pounds of Sulfur per million Btu $\ldots \ldots \ldots \ldots \ldots \ldots$ & .47 & .50 \\
\hline Dollars per million Btu $\ldots \ldots \ldots \ldots \ldots \ldots \ldots \ldots \ldots$ & 1.10 & 1.37 \\
\hline Dollars per short ton $\ldots \ldots \ldots \ldots \ldots \ldots \ldots \ldots \ldots$ & 24.28 & 28.31 \\
\hline
\end{tabular}

Estimated Total State Enorgy Consumption, 1991: 924 trillion Btu (coal, 348; natural gas, 128; petroleum, 353; nuclear electric power, 270; hydroelectrlc power, 75; othor, 0 ; not interstate flow of electriclity and aseoclated losese, -250 ).

W $=$ Withheld to avoid disclosure of individual company data.

Notes: Totals may not equal sum of components because of independent rounding. Data coverage-Production: all mines. Number of minces: 1980, mines that produced 10,000 short tons or more; other years, all mines. Number of miners and productivity: mines that produced 10,000 or more short tons and preparation plants that had 5,000 or more employee hours. Average mine price: mines that produced 10,000 or more short tons. Average quality and average delivered cost of utlity coal: power plants with a generator nameplate capacity of 50 megawatts or more. Extent of coal-bearing areas and locations of coalconsuming plants shown on map are approximate; small coal deposits are not shown. Coal-producing counties shown on map exclude any county where all 1992 output was from mines producing less than 10,000 short tons.

Sources: Energy Information Administration-U.S. Coal Reserves: An Update by Heat and Sulfur Content, February 1993; Coal Production 1992 and prior Issues; Coal Data: A Reference; i interly Coal Report October-December 1992 and prior issues; Electric Power Annual 1991 and prior issues; Electric Power Monthly, March 1993; Cost and Quslity of Fuels for Electric Power Plants 1992; Inventory of Power Plants in the United States 1992; State Energy Data Repurt 1991: Consumption Estimates; Map of coal-bearing areas is based mainly on U.S. Geological Survey map, Coalfields of the United States, 1960. Data for historical graph 1890-1975, U.S. Department of the Interior, Geological Survey and Bureau of Mines (Minerals Yearbook and annual predecessor Mineral Resources of the United States); 1976 forward, Energy Information Administration, Coal Production 1992 and prior issues. 


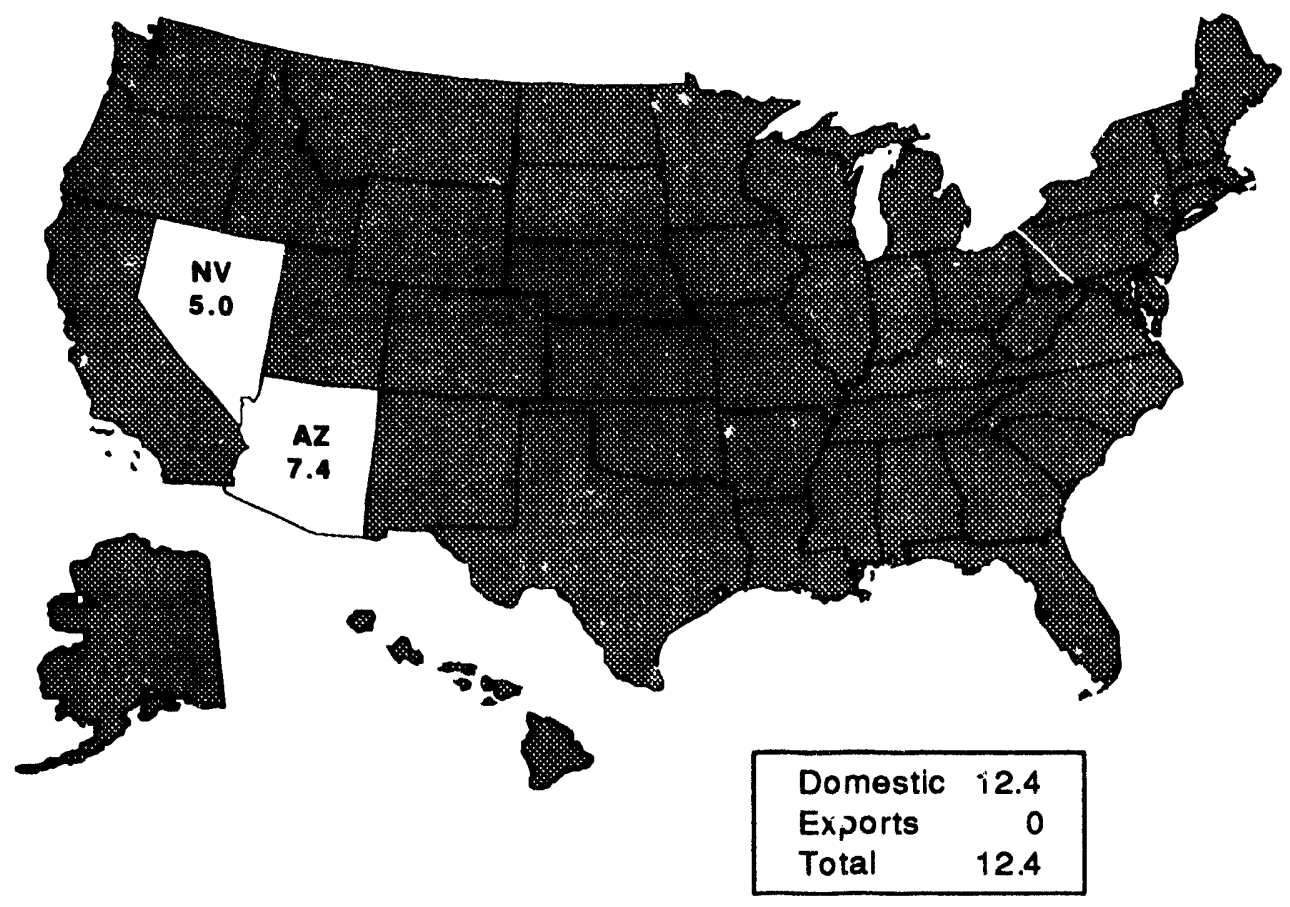

Transportation modes, domestic markets (percent): rail, 60; tramway/conveyor/slurry pipeline, 40.

Note: Total may not equal sum of components because of independent rounding.

Source: Energy Information Administration, Form EIA6, "Coal Distribution Report."

\section{Origin of Coal Recelved in Arizona, 1992}

(Million Short Tons)

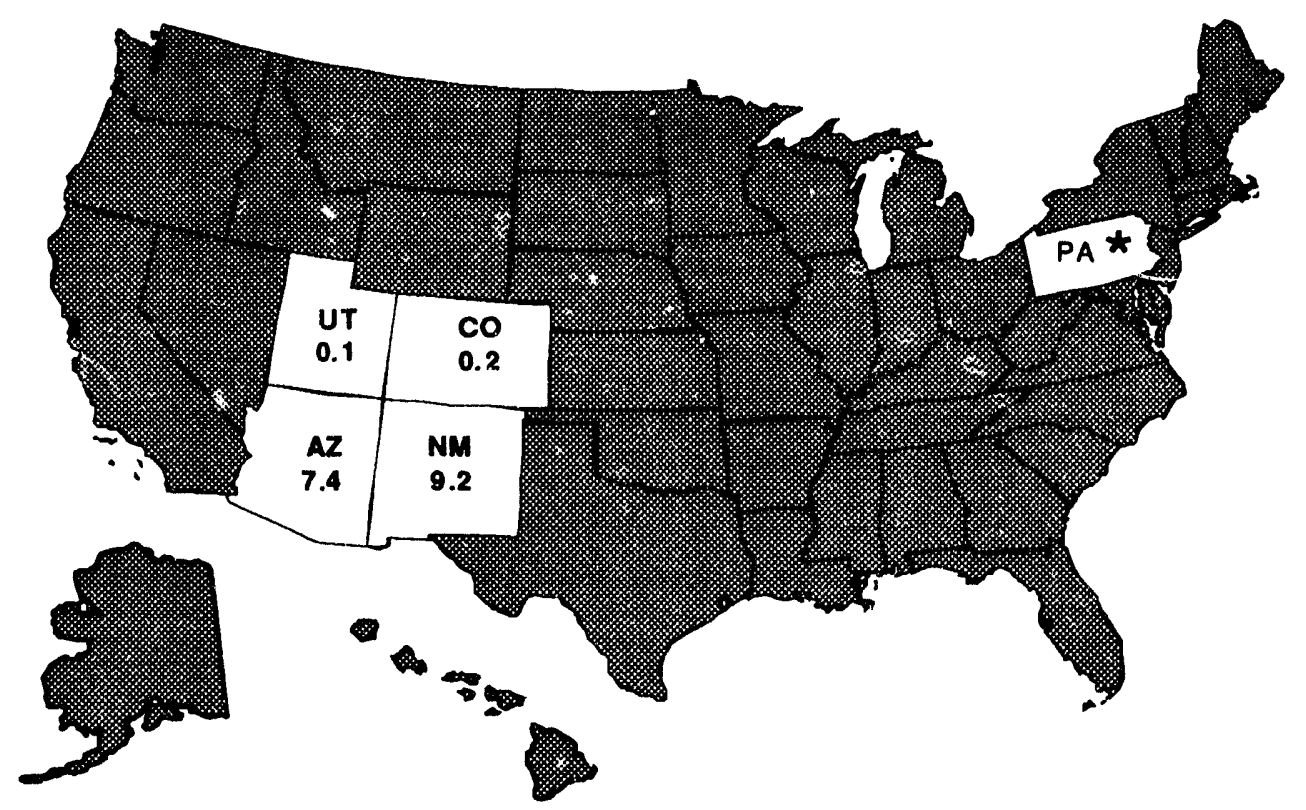

Total

16.9

Note: Total may not equal sum of components because of independent rounding.

Source: Energy Information Administration, Form EIA-6, "Coal Distribution Report." 


\section{State Coal Profile: Arkansas}

As a source of coal, Arkansas is relatively insignificant. Its 1992 output of 58,000 short tons was the smallest of all States. The value of the coal was less than 1 percent of the estimated value of all mineral commodities produced in the State.

The Arkansas coal deposits consist mostly of bituminous coal and semianthracite in the western Arkansas Valley. The area, an eastern extension of the Oklahoma coal-bearing region, is about 30 miles wide and 90 miles long. The geologic formations in the Arkansas Valley have been considerably folded and faulted, and the coalbeds often thin out. These features have contributed to the cost of mining in the area. Lignite occurs in the coastal plain in the southern and northeastern parts of the State. Currently, only bituminous coal is mined in Arkansas. The Lower Hartshone coalbed, which averages about 2 feet in thickness, is the most productive and extensive coalked in the State. It has a heat value averaging 26 million Btu per short ton (as-received basis) and a sulfur content averaging between 1 and 2 percent (by weight).

Coal was first mined in Arkansas around 1840, but production did not become economically important until about 1870, after railroads expanded into the Arkansas Valley. Although the output was chiefly bituminous coal, small amounts of lignite were also produced for use as boiler fuel, local heating, and a source of clistilled oil. After reaching a peak of nearly 3 million sinort tons in 1907, production declined due to competition from other fuels, including oil and natural gas disco rered in the State. It rose slightly during
World War II, but afterwards fell sharply to an annual average of less than 100,000 short tons. Virtually all production has been bituminous coal, including some used in the past for making metallurgical coke, and some semianthracite. A small amount of lignite was mined in the late 1930's and early 1940's to produce Van Dyke brown dye and montan wax, a fossil plant wax used for industrial purposes. In 1988, a small amount of lignite was used for test-burning as a blend with western coal in a local power plant.

Underground mines accounted for the bulk of the early coal production in Arkansas, but surface mines have predominated since 1958. Coal was last mined underground in Arkansas in 1978. Production in 1992 was from Johnson and Sebastian counties. The State's largest coal producer was the Wilken No. 1 surface mine of Mid-America Mining and Development Company, in Sebastian County.

In 1992, about half of the coal produced was shipped out of the State. Virtually all of the 13 million short tons of coal consumed in Arkansas in 1992 was used to generate electricity. All of the utility coal was subbituminous coal from Wyoming. This was consumed at two power plants with nearly equal coal-fired electricity generating capabilities, both operated by Arkansas Power and Light Company: the 1,678-megawatt Independence plant, in Independence County, and the 1,659-megawatt While Bluff plant, in Jefferson County. A small amount of coal was consumed for other industrial use, mainly at a paper mill and a cement plant. 

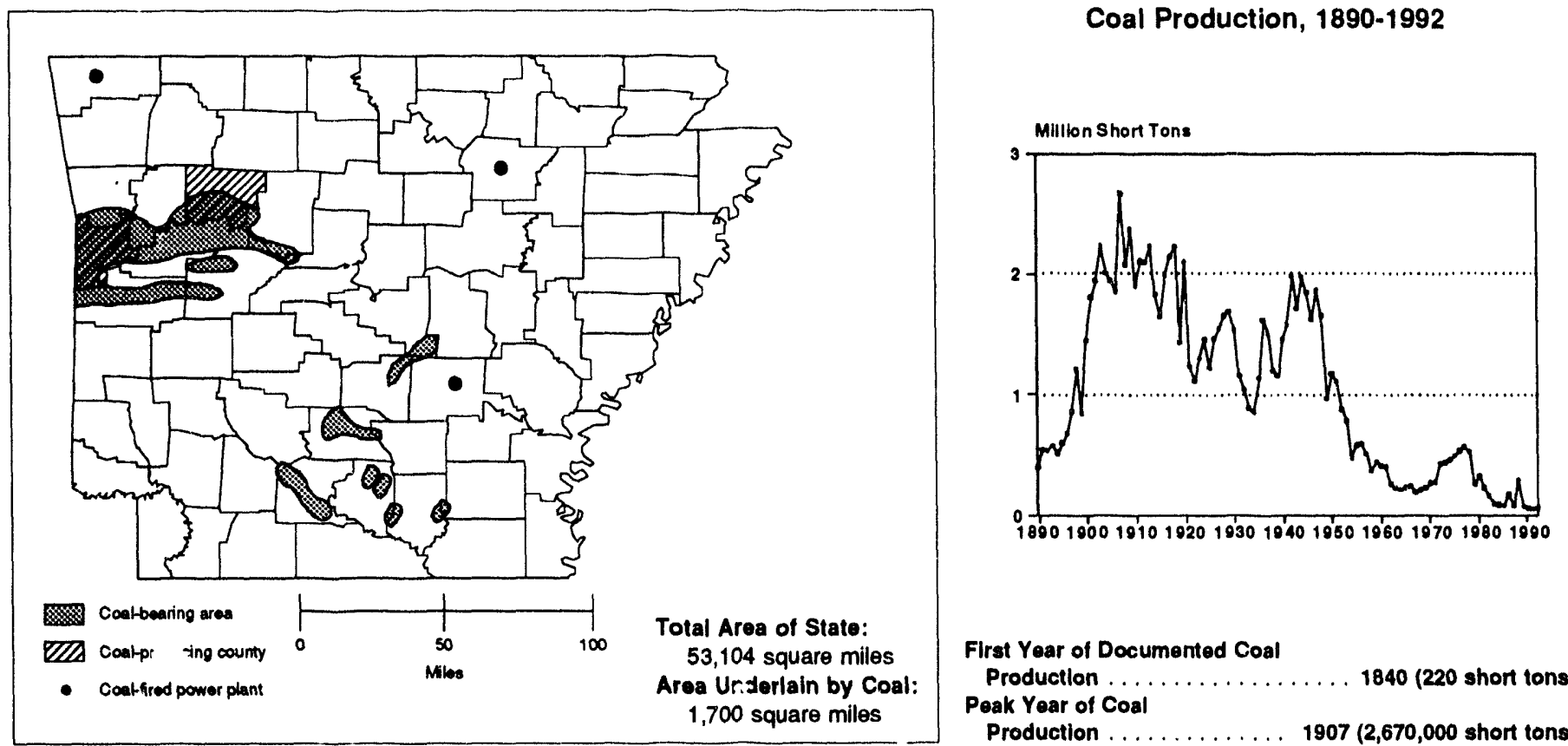

\section{Coal Reserves (Million Short Tons)}

\begin{tabular}{|c|c|c|c|}
\hline Type of Reserve & Underground & Surtace & Total \\
\hline Demonstrated Reserve Base: & 273 & 145 & 417 \\
\hline \multicolumn{4}{|l|}{ Estimatod Rocovorablo Resorves: } \\
\hline$<0.61$ (low sulfur) $\ldots \ldots \ldots \ldots$ & 7 & 2 & 8 \\
\hline $0.61-1.67$ (medium sulfur) . . . . . . & 110 & 97 & 207 \\
\hline $\begin{array}{l}\text { Estlmated Recoverable Resorves } \\
\text { at Active Mines, Year-End } 1992 \ldots \ldots \ldots \ldots \ldots \text {. }\end{array}$ & 0 & $w$ & w \\
\hline
\end{tabular}

\section{Production}

\begin{tabular}{|c|c|c|c|c|c|}
\hline Sallent Data by Mine Type & 1980 & 1985 & 1990 & 1991 & 1992 \\
\hline \multicolumn{6}{|l|}{ Underground } \\
\hline Quantity (thousand short lons) & 0 & 0 & 0 & 0 & 0 \\
\hline Mines $\ldots \ldots \ldots \ldots \ldots \ldots \ldots \ldots \ldots \ldots \ldots \ldots \ldots \ldots \ldots \ldots \ldots$ & 0 & 0 & 0 & 0 & 0 \\
\hline Miners $\ldots \ldots \ldots \ldots \ldots \ldots \ldots \ldots \ldots \ldots \ldots \ldots \ldots \ldots \ldots$ & 0 & 0 & 0 & 0 & 0 \\
\hline Productivity (shon tons per miner per hour) $\ldots \ldots \ldots \ldots \ldots$ & -- & -. & -. & -. & .. \\
\hline Average Mine Price (dollars per short ton) . . . . . . . . . . & 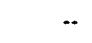 & $\cdots$ & 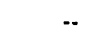 & $\cdots$ & $\cdots$ \\
\hline \multicolumn{6}{|l|}{ Surface } \\
\hline Quantity (thousand short tons) $\ldots \ldots \ldots \ldots \ldots \ldots \ldots$ & 349 & 80 & 59 & 52 & 58 \\
\hline Mines $\ldots \ldots \ldots \ldots \ldots \ldots \ldots \ldots \ldots \ldots \ldots$ & 4 & 7 & 7 & 7 & 6 \\
\hline 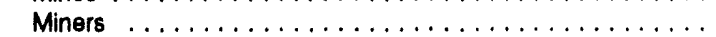 & 75 & 26 & 13 & 14 & 14 \\
\hline Productivity (short tons per miner per hour) $\ldots \ldots \ldots \ldots$ & 1.21 & 1.80 & 1.46 & 2.27 & 1.68 \\
\hline Average Mine Price (dollars per short ton) $\ldots \ldots \ldots \ldots \ldots$ & 41.83 & W & $W$ & W & W \\
\hline \multicolumn{6}{|l|}{ Total } \\
\hline Quantity (thousand short tons) & 319 & 80 & 59 & 52 & 58 \\
\hline Mines $\ldots \ldots \ldots \ldots \ldots \ldots \ldots \ldots \ldots \ldots \ldots$ & 4 & 7 & 7 & 7 & 6 \\
\hline 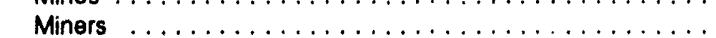 & 75 & 26 & 13 & 14 & 14 \\
\hline Productivity (shon tons per miner per hour) $\ldots \ldots \ldots \ldots \ldots$ & 1.21 & 1.80 & 1.46 & 2.27 & 1.68 \\
\hline Average Mine Price (dollars per short ton) $\ldots \ldots \ldots \ldots \ldots$ & 41.83 & $W$ & W & $w$ & $W$ \\
\hline
\end{tabular}




\section{Arkansas}

Number of Mines by Production Range and Percent of Production, 1992

\begin{tabular}{|c|c|c|c|c|c|c|c|c|}
\hline \multirow{3}{*}{ Mine Type } & \multicolumn{8}{|c|}{ Production Range (thuusand short tons) } \\
\hline & \multicolumn{2}{|c|}{1,000 and over } & \multicolumn{2}{|c|}{500 to 999} & \multicolumn{2}{|c|}{10010499} & \multicolumn{2}{|c|}{$<100$} \\
\hline & Number & Percent & Number & Percent & Number & Percent & Number & Percont \\
\hline Underground & 0 & 0 & 0 & 0 & 0 & 0 & 0 & 0 \\
\hline$\ldots \ldots \ldots \ldots \ldots$ & 0 & 0 & 0 & 0 & 0 & 0 & 6 & 100 \\
\hline All Mines $\ldots \ldots \ldots \ldots \ldots \ldots \ldots \ldots \ldots$ & 0 & 0 & 0 & 0 & 0 & 0 & 6 & 100 \\
\hline
\end{tabular}

\section{Coal Demand}

\begin{tabular}{|c|c|c|c|c|c|}
\hline Diepoetilon & 1980 & 1985 & 1990 & 1991 & 1992 \\
\hline \multicolumn{6}{|l|}{ Consumption (thousand short tons) } \\
\hline Electric Utilities $\ldots \ldots \ldots \ldots \ldots$ & 1,774 & 12,302 & 11,836 & 11,978 & 12,325 \\
\hline$\ldots \ldots \ldots \ldots \ldots$ & 0 & 0 & 0 & 0 & 0 \\
\hline Other Industrial $\ldots \ldots \ldots \ldots \ldots \ldots$ & 296 & 379 & 256 & 283 & 295 \\
\hline Residential and Commercial $\ldots \ldots \ldots$ & 6 & 1 & 0 & 0 & 2 \\
\hline Total $\ldots \ldots \ldots \ldots \ldots \ldots \ldots$ & 2,076 & 12,682 & 12,092 & 12,261 & 12,622 \\
\hline \multicolumn{6}{|l|}{ Year-End Utility Stocke } \\
\hline (thousand short tons) $\ldots \ldots \ldots$ & 1,964 & 2,513 & 1,722 & 2,150 & 1,572 \\
\hline \multicolumn{6}{|l|}{ Electriotty Generation } \\
\hline Total (million kilowatthours) & 19,685 & 35,565 & 37,053 & 38,365 & 37,507 \\
\hline Coal (percent) $\ldots \ldots \ldots \ldots \ldots \ldots$ & 15 & 57 & 52 & 51 & 54 \\
\hline Nuclear (percent) $\ldots \ldots \ldots \ldots \ldots \ldots$ & 40 & 28 & 30 & 33 & 30 \\
\hline Other (percent) $\ldots \ldots \ldots \ldots \ldots \ldots$ & 45 & 15 & 18 & 16 & 16 \\
\hline
\end{tabular}

Utility Coal Data, 1992

\begin{tabular}{|c|c|c|}
\hline Average Quality and Average Dolivered Coat & Produced in State & Rocelpts, All Sources \\
\hline Heat Content (million Btu per short ton) ..... & .. & 17.45 \\
\hline Sulfur Content (percent by weight) $\ldots \ldots \ldots \ldots \ldots \ldots$ & .. & .32 \\
\hline Ash Content (percent by weight) $\ldots \ldots \ldots \ldots \ldots \ldots \ldots$ & .. & 5.12 \\
\hline Pounds of Sulfur per million Btu $\ldots \ldots \ldots \ldots \ldots \ldots \ldots$ & .. & .37 \\
\hline Dollars per million Btu $\ldots \ldots \ldots \ldots \ldots \ldots \ldots \ldots \ldots \ldots$ & .. & 1.85 \\
\hline 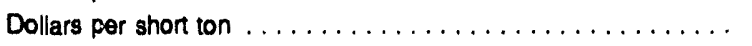 & .. & 28.84 \\
\hline
\end{tabular}

Estimated Total State Energy Consumption, 1991: 770 trillion Btu (cosl, 216; natural gas, 213; potroloum, 271; nuclear electric powor, 136; hydroalectric power, 37; other, 0; net interatate flow of electrichy and asecciated losese, -103).

$W=$ Withheid to avoid disclosure of individual company data.

Notes: Toials may not equal sum of components because of independent rounding. Data coverago-Production: all mines. Number of mines: 1980 , mines that produced 10,000 short tons or more; other years, all mines. Number of miners and productivity: mines that prod _ced 10,000 or more short tons and preparation plants that had 5,000 or more employee hours. Average mine price: mines that produced 10,000 or more shor، tons. Average qualty and average delivered coat of utility coal: puwer plants with a generator nameplate capacity of 50 megawatts of more. Extent of coal-bearing areas and locations of coalconsuming plants shown on map are approximate; small coal deposits are not shown. Coal-producing counties shown on map exclude any county where all 1992 output was from mines producing less than 10,000 short tons.

Sources: Energy Information Administration-U.S. Coal Reserves: An Update by Heat and Sulfur Content, February 1993; Coal Production 1992 and prior issues; Coal Data: A Reference; Quarterly Coal Report October-December 1992 and prior issues; Electric Power Annual 1991 and prior issues; Electric Power Monthly, March 1993; Cost and Quality of Fuels tor Electric Power Plants 1992; Inventory of Power Plants in the United States 1992; State Energy Data Report 1991: Consumption Estimates; Map of coal-bearing areas is based mainly on U.S. Geological Survey map, Coalfields of the United Stales, 1960. Data for historical graph 1890-1975, U.S. Department of the Interior, Geological Sunvey and Bureau of Mines (Minerals Yearbook and annual predecessor Mineral Resources of the United Stales); 1976 fonward, Energy Information Administration, Coal Production 1992 and prior issues. 
Destination of Coal Produced In Arkansas, 1992

(Million Short Tons)

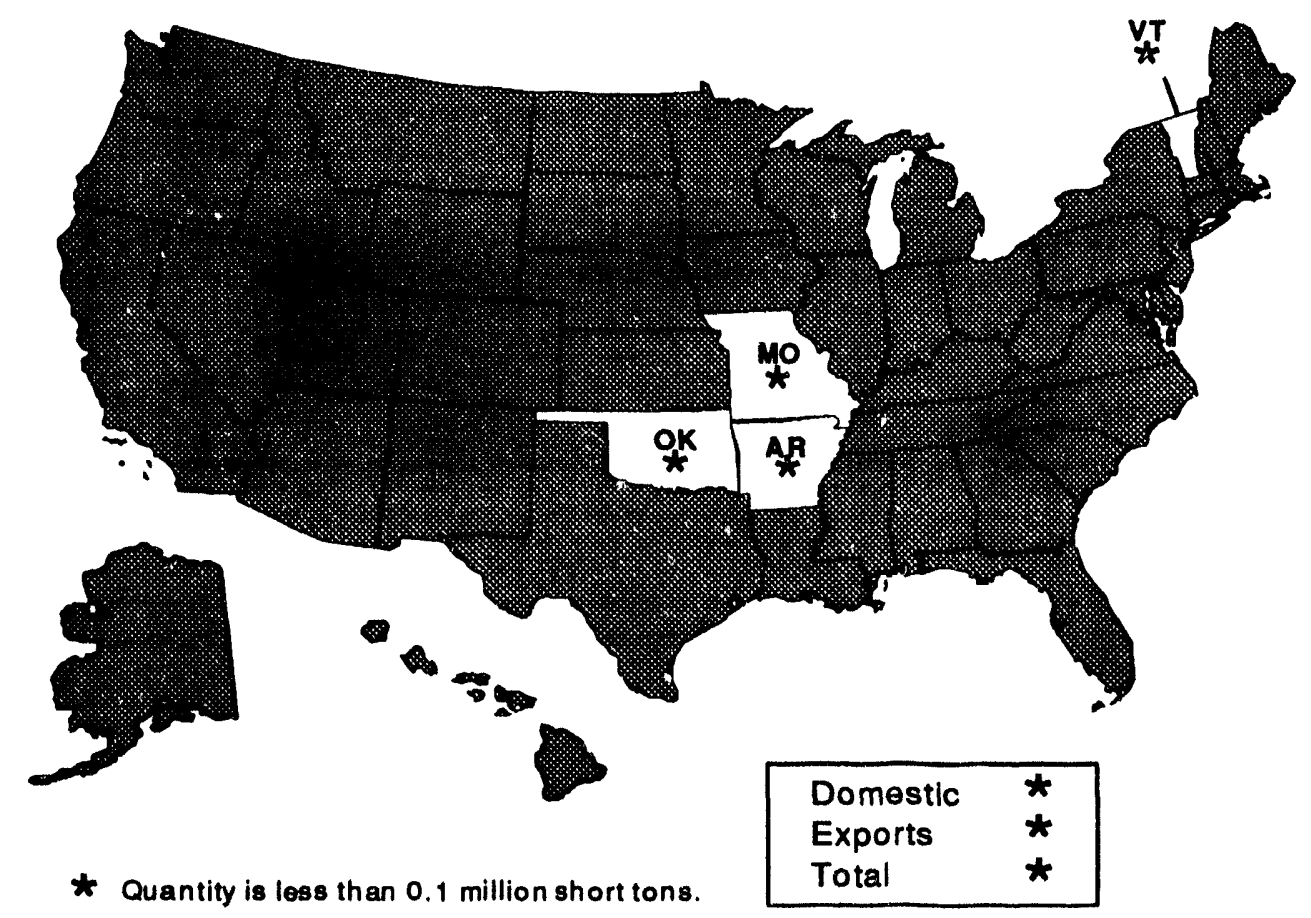

Transportation modes, domestic markets (percent): truck, 100.

Source: Energy Information Administration, Form EIA-6, "Coal Distribution Report."

Origin of Coal Recelved in Arkansas, 1992

(Million Short Tons)

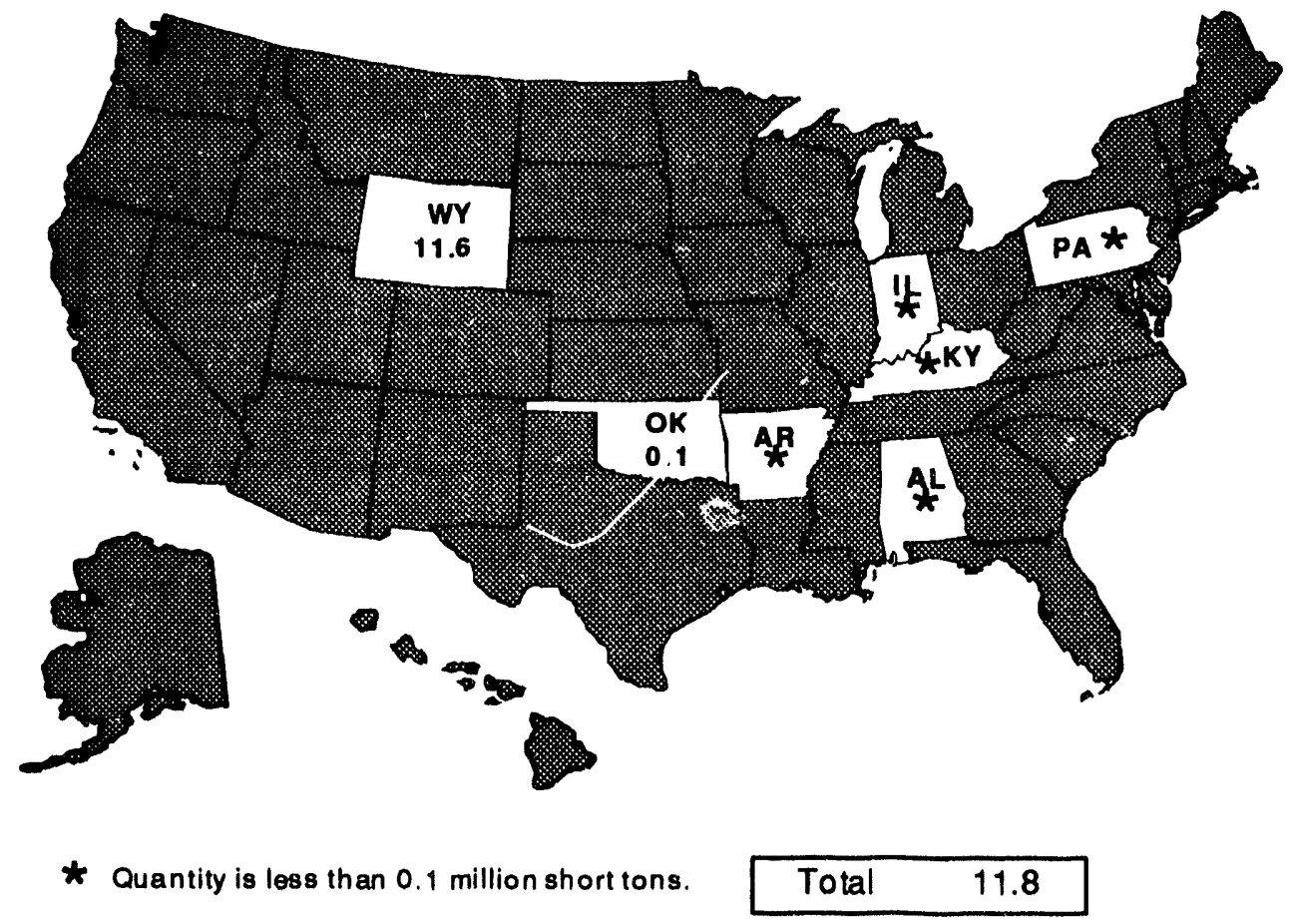

Note: Total may not equal sum of components because of independent rounding.

Source: Energy Information Administration, Form EIA-6, "Coal Distribution Report." 


\section{State Coal Profile: California}

Coal occurs in California in small, widely scattered deposits that range in rank from lignite to bituminous. A small amount of lignite is surface mined as a source of montan wax by Jackson Valley Energy Partners, L. P., near Ione, Amador County. The operation is unique because it is the only U.S. coal deposit mined for montan wax, a fossil plant wax (found in only a few American lignites) used for industrial purposes.

Coal was mined in California as early as 1855 , but coal mining as an industry began in 1861 . Much of the early production was from Contra Costa County. Coal was used as fuel for railroads, steamboats, flour mills, manufacturing plants, and domestic heating. Total output reached a peak of 237,000 short tons in 1880, about the time when large deposits of oil and natural gas were discovered in the State. After 1900, production dropped sharply and became practically insignificant as oil and gas displaced coal as a source of energy in the State.

At the end of World War II, California's lignite deposits were among those investigated as part of a Federal program to locate domestic deposits with a high wax content. The search was prompted by a wartime shortage of montan wax, which had been imported chiefly from Germany. The lignite deposit near Ione was one of the few found to have a wax content of economic potential. In 1947, the deposit, mined initially to produce lignite briquettes, was developed as a source of montan wax.

The Ione lignite bed, 12 to 15 feet thick, is surface mined selectively after drilling has located areas with a high wax content. It is mined during the driest summer months and stockpiled at the wax plant for use throughout the year. The level of production is governed by the market for montan wax. Production in 1992 was 103,000 short tons. Montan wax is extracted from dried, pulverized lignite through the use of solvents. The wax is hard and brittle and has a high melting point; its properties are similar to those of natural plant waxes, such as carnauba, which it can replace. Most of the wax undergoes additional processing to produce waxes for specific uses. The principal use is in hot-melt carbon inks. Other applications include spray lubricants, thin-film temporary coatings, release agents for molded phenolic parts and polyurethane fiber board, protective coatings, special waterproofing compounds, and ink additives.

Lignite residue from wax production is used as fuel in an adjacent 15-megawatt fluidized-bed cogeneration plant that began commercial operation in 1987. The lignite residue has a heat content of about 10 million Btu per short ton. Steam, hot air, and some of the electricity produced at the facility are sold to the wax plant. Most of the electricity produced is sold to Pacific Gas and Electric Company. A small amount of lignite residue is also sold as a soil conditioner.

Although wax production represents the most unusual use of coal in California, considerably more coal is used as a fuel. Most of the 3 million short tons of coal consumed in 1992 was produced in Utah. Cement plants were the major coal consumers, accounting for more than half of the State's total. More than one-third was used as a source of heat for producing sodium carbonate from natural brines. Until 1983, coal from Utah and New Mexico was converted into coke at Fontana and used to manufacture steel. No coal is used in the State's power plants.

Several ports in California are shipping points for coal exports from western mines. Los Angeles is by far the principal coal-exporting district, accounting for most of the 3 million short tons of coal exported through California in 1992. 


\section{California}

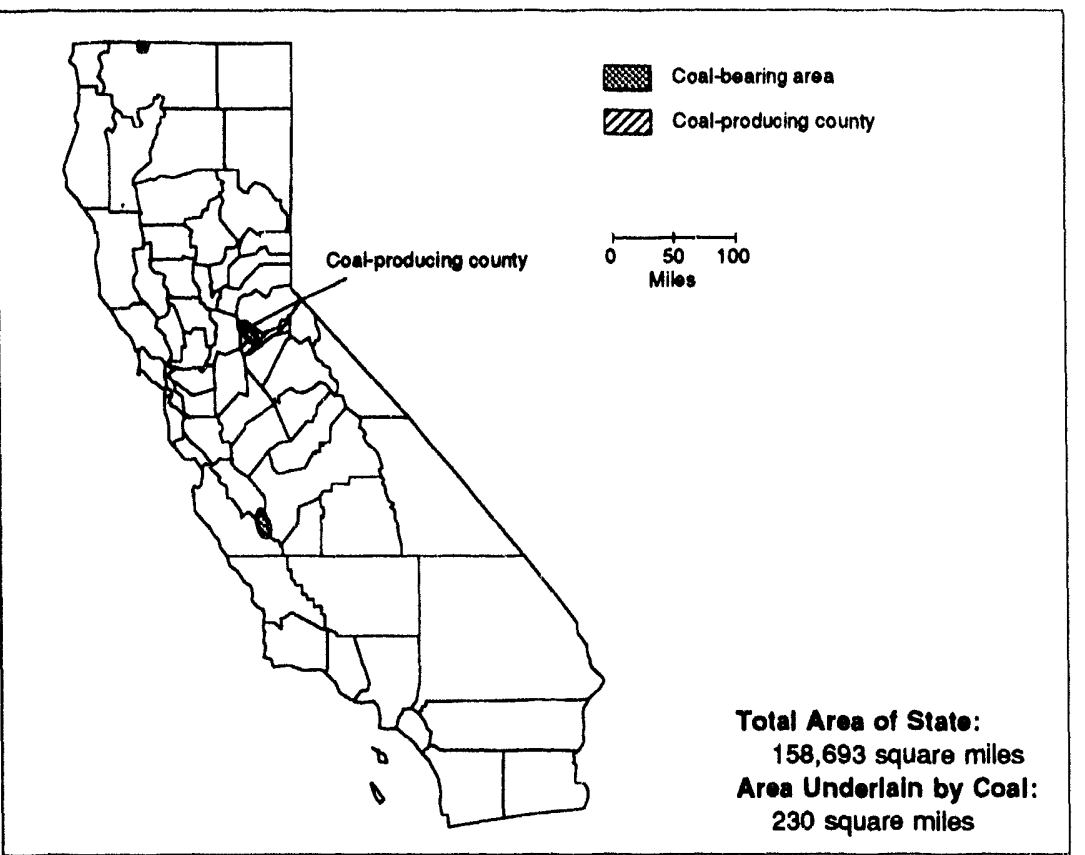

Coal Production, 1890-1992

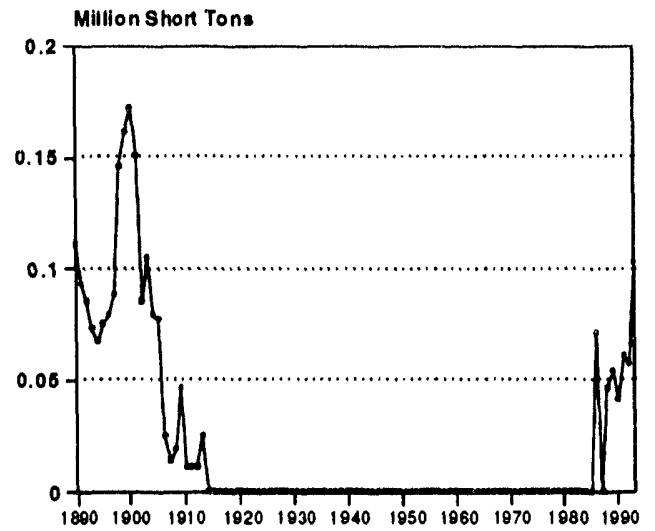

First Year of Documented Coal

Production . . . . . . . . . . . 1861 (6,620 short tons) Peak Year of Coal Production . . 1880 (237,000 short tons)

\section{Coal Reserves (Million Short Tons)}

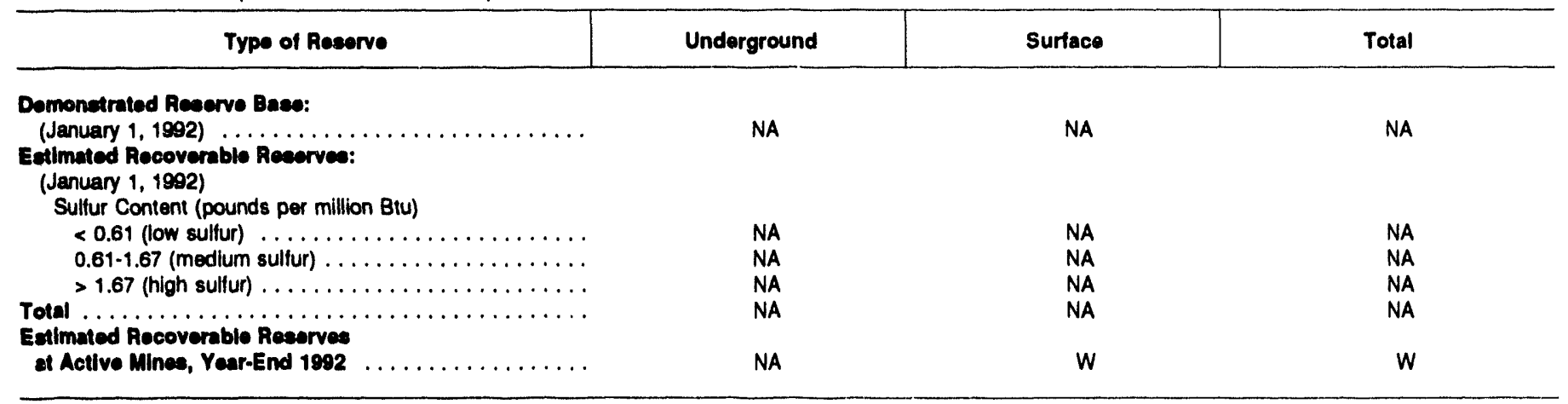

\section{Production}

\begin{tabular}{|c|c|c|c|c|c|}
\hline Sallent Data by Mine Type & 1980 & 1985 & 1990 & 1991 & 1992 \\
\hline \multicolumn{6}{|l|}{ Undereround } \\
\hline Quantity (thousand short tons) $\ldots \ldots \ldots \ldots \ldots \ldots \ldots$ & 0 & 0 & 0 & 0 & 0 \\
\hline 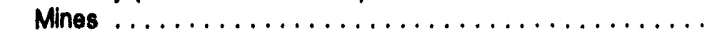 & 0 & 0 & 0 & 0 & 0 \\
\hline 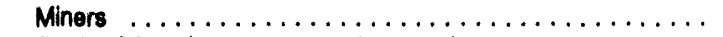 & 0 & 0 & 0 & 0 & 0 \\
\hline Productivity (short tons per miner per hour) $\ldots \ldots \ldots \ldots \ldots$ & - & $\cdots$ & $\cdots$ & $\cdots$ & -- \\
\hline Average Mine Price (dollars per short ton) . . . . . . . . . & -- & -- & -- & - & -- \\
\hline \multicolumn{6}{|l|}{ Surtece } \\
\hline Quantity (thousand short tons) $\ldots \ldots \ldots \ldots \ldots \ldots$ & 0 & 71 & 61 & 57 & 103 \\
\hline 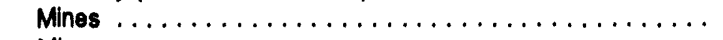 & 0 & 1 & 1 & 1 & 1 \\
\hline 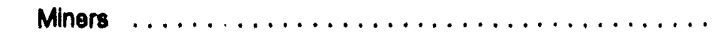 & 0 & 9 & 5 & 8 & 8 \\
\hline Productivity (short tons per miner per hour) $\ldots \ldots \ldots \ldots \ldots$ & - & 4.23 & 17.69 & 11.31 & 11.12 \\
\hline Average Mine Price (dollars per short ton) $\ldots \ldots \ldots \ldots \ldots$ & $\because$ & $W$ & W & W & W \\
\hline \multicolumn{6}{|l|}{ Total } \\
\hline Quantity (thousand short tons) & 0 & 71 & 61 & 57 & 103 \\
\hline 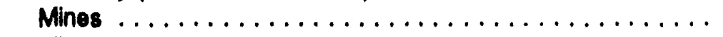 & 0 & 1 & 1 & 1 & 1 \\
\hline 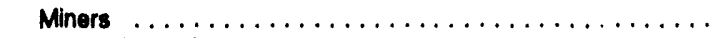 & 0 & 9 & 5 & 8 & $\mathbf{B}$ \\
\hline Productivity (shon tons per miner per hour) . . . . . . . . . & -- & 4.23 & 17.69 & 11.31 & 11.12 \\
\hline Average Mine Price (dollars per short ton) . . . . . . . . . . & -- & W & W & W & W \\
\hline
\end{tabular}




\section{California}

Number of Mines by Production Raijge and Percent of Production, 1992

\begin{tabular}{|c|c|c|c|c|c|c|c|c|}
\hline \multirow{2}{*}{ Mine Type } & \multicolumn{8}{|c|}{ Production Range (thousand short tons) } \\
\hline & Number & Percent & Number & Percent & Number & Percent & Number & Percent \\
\hline Underground & 0 & 0 & 0 & 0 & 0 & 0 & 0 & 0 \\
\hline$\ldots \ldots \ldots \ldots \ldots$ & 0 & 0 & 0 & 0 & 1 & 100 & 0 & 0 \\
\hline All Mines $\ldots \ldots \ldots \ldots \ldots \ldots \ldots \ldots \ldots \ldots \ldots$ & 0 & 0 & 0 & 0 & 1 & 100 & 0 & 0 \\
\hline
\end{tabular}

Coal Demand

\begin{tabular}{|c|c|c|c|c|c|}
\hline Disposition & 1980 & 1985 & 1990 & 1991 & 1992 \\
\hline \multicolumn{6}{|l|}{ Consumption (thousand short tons) } \\
\hline Electric Uallities . . . . . . . . . . . . & 0 & 0 & 0 & 0 & 0 \\
\hline Other Industrial . . . . . . . . . . . & 1,155 & 1,889 & 2,874 & 2,771 & 2,821 \\
\hline Residential and Commercial ........ & 4 & 53 & 25 & 44 & 0 \\
\hline Total $\ldots \ldots \ldots \ldots \ldots \ldots \ldots \ldots$ & 2,669 & 1,942 & 2,899 & 2,816 & 2,821 \\
\hline \multicolumn{6}{|l|}{ Year-End Utillty Stocks } \\
\hline (thousand short tons) $\ldots \ldots \ldots \ldots$ & 0 & 0 & 0 & 0 & 0 \\
\hline \multicolumn{6}{|l|}{ Electricity Genoration } \\
\hline Total (million kilowatthours) . . . . . . . . & 140,341 & 127,846 & 114,528 & 04,968 & 119,308 \\
\hline Coal (percent) $\ldots \ldots \ldots \ldots \ldots \ldots$ & 0 & 0 & 0 & 0 & 0 \\
\hline Nudear (percent) $\ldots \ldots \ldots \ldots \ldots$ & 4 & 15 & 29 & 30 & 30 \\
\hline
\end{tabular}

\section{Utillty Coal Data, 1992}

\begin{tabular}{|c|c|c|}
\hline Average Quality and Average Delivered Cost & Produced in State & Recelpts, All Sources \\
\hline Heat Content (million Btu per shart ton) $\ldots \ldots \ldots$ & $\cdots$ & -. \\
\hline Sulfur Content (percent by weight) $\ldots \ldots \ldots \ldots \ldots \ldots$ & $-\cdot$ & $-\cdot$ \\
\hline Ash Content (percent by weight) $\ldots \ldots \ldots \ldots \ldots \ldots$ & $-\cdot$ &.- \\
\hline Pounds of Sultur per million Btu $\ldots \ldots \ldots \ldots \ldots \ldots$ & -. & .. \\
\hline Dollars per million Btu $\ldots \ldots \ldots \ldots \ldots \ldots \ldots \ldots \ldots$ & $\cdots$ & -. \\
\hline Dollars per short ton $\ldots \ldots \ldots \ldots \ldots \ldots \ldots \ldots \ldots$ & -. & -. \\
\hline
\end{tabular}

Estimated Total State Energy Consumption, 1991: 7,162 trillion Btu (coal, 64; natural gas, 2,024; petroleum, 3,283; nuclear electric power, 339; hydroelectric power, 283; ofher, 166; not Interstate flow of electricity and associated losees, 1,003).

$W=$ Withheld to avoid disclosure of individual company data.

NA $=$ Not available.

Notes: Data coverage_Production: all mines. Number of mines: 1980, mines that produced 10,000 short tons or more; other years, all mines. Number of miners, and productivity, mines that produced 10,000 or more short tons and preparation plants that had 5,000 or more employee hours. Average mine price: mines that produced 10,000 or more short tons. Average quality and average delivered cost of utllity coal: power plants with a generator nameplate capacity of 50 megawatts or more. Totals may not equal sum of components because of independent rounding. Extent of coal-bearing areas and locations of coalconsuming plants shown on map are approximate; small coal deposits are not shown. Coal-producing counties shown on map exclude any county where all 1992 output was from mines producing less than 10,000 short tons.

Sources: Energy Information Administration-U.S. Coal Reserves: An Update by Heat and Sulfur Content, February 1993 ; Coal Production 1992 and prior issues; Coal Data: A Reference; Quarterly Coal Report October-December 1992 and prior issues; Electric Power Annual 1991 and prior issues; Electric Power Monthly, March 1993; Cost and Quality of Fuels for Electric Power Plants 1992; Inventory of Power Plants in the United States 1992; State Energy Data Report 1991: Consumption Estimates; Map of coal-bearing areas is based mainly on U.S. Geological Survey map, Coalfields of the United States, 1960. Data for historical graph 1890-1975, U.S. Department of the Interior, Geological Survey and Bureau of Mines (Minerals Yearbook and annual predecessor Mineral Resources of the United States); 1976 forward, Energy Information Administration, Coal Production 1992 and prior issues. 
Doatination of Coal Produced in Calfornia, 1992

(Million Short Tons)

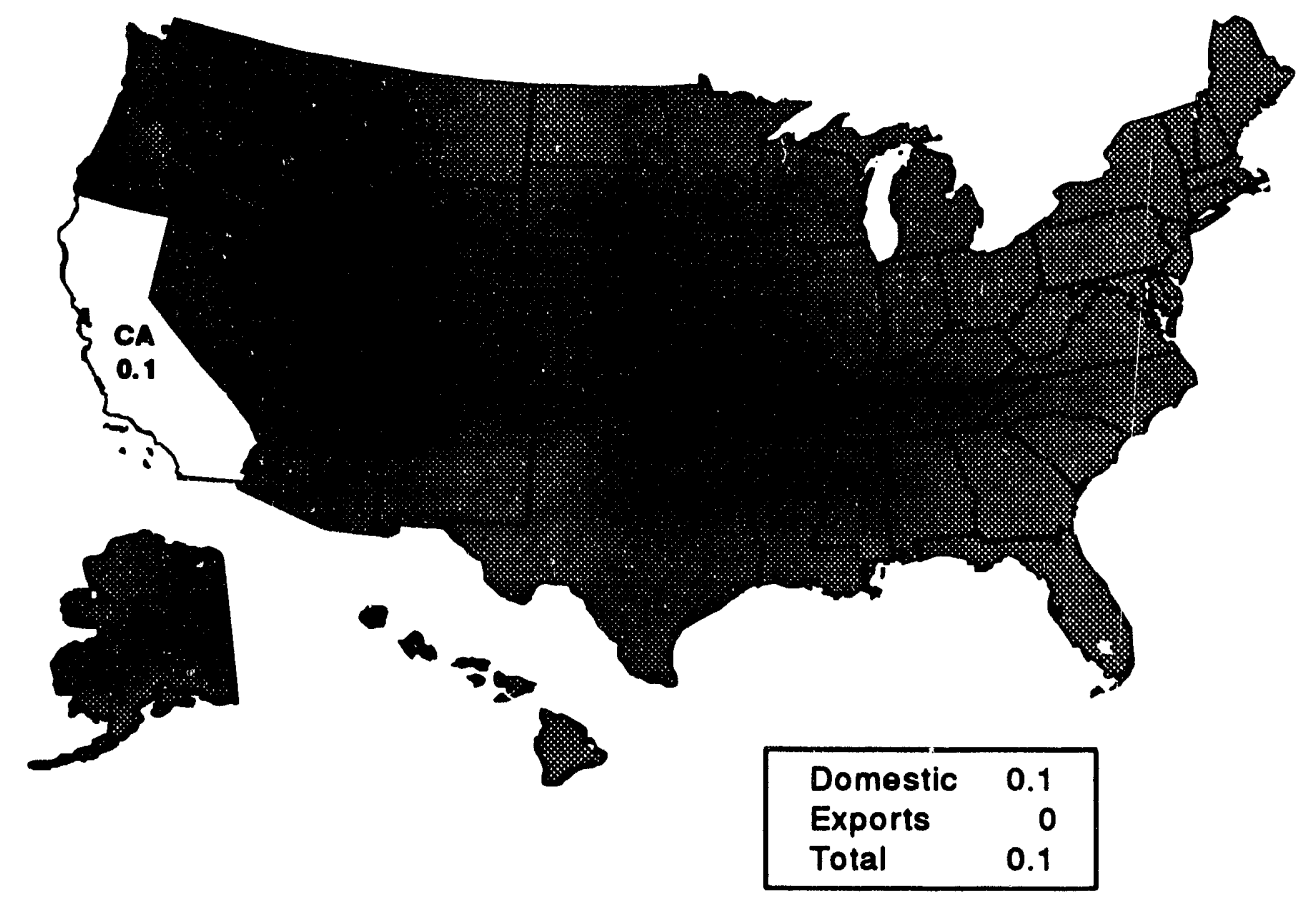

Transportation modes, domestic markets (percent): truck, 100.

Note: Total may not equal sum of components because of independent rounding.

Source: Energy Information Administration, Form EIA-6, "Coal Distribution Report."

Origin of Coal Recelved in Callfornia, 1992

(Million Short Tons)

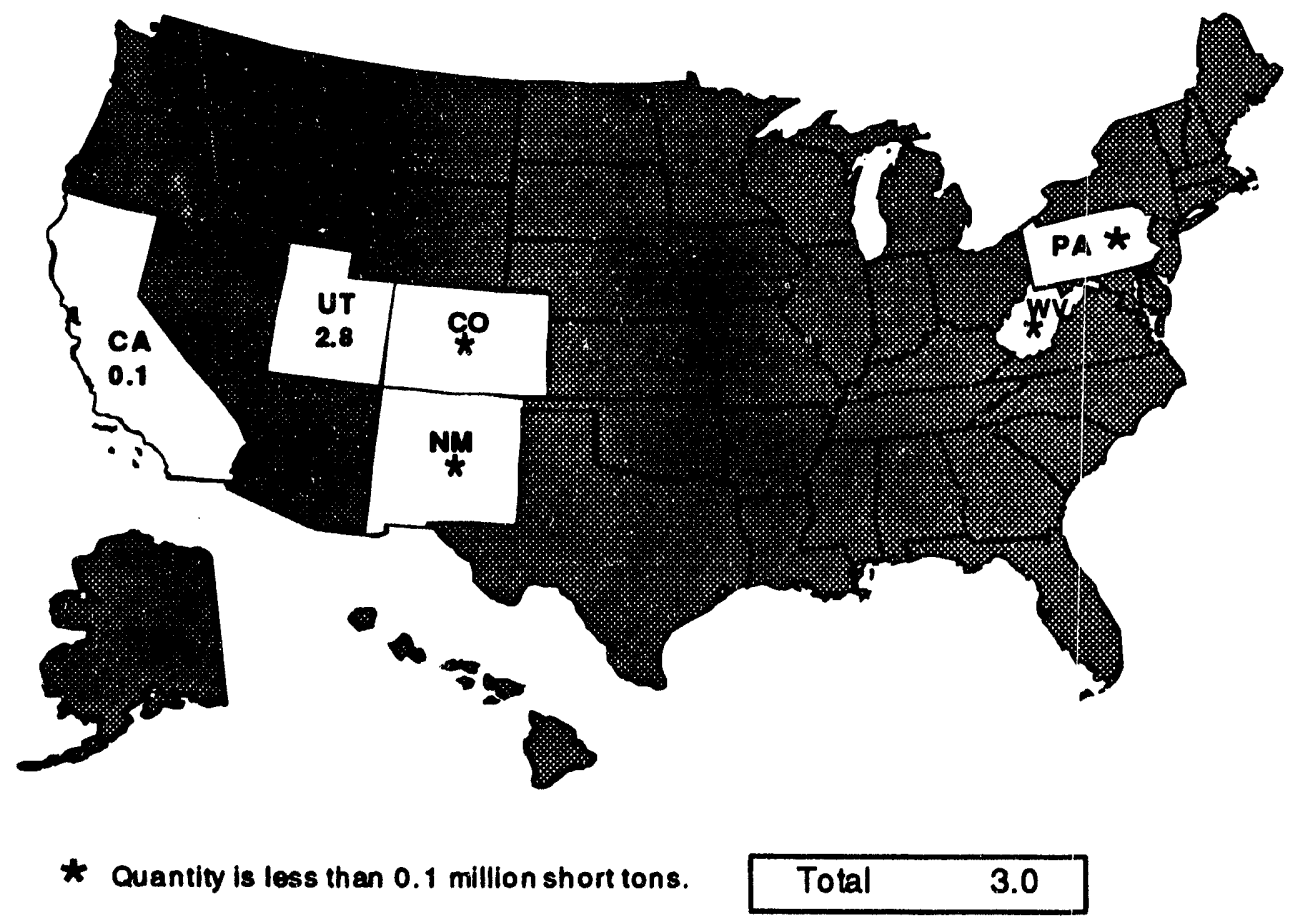

Note: Total may not equal sum of components because of independent rounding.

Source: Energy Information Administration, Form EIA-6, "Coal Distribution Report." 


\section{State Coal Profile: Colorado}

The value of coal production in Colorado in 1992 accounted for about 22 percent of the estimated total value of all mineral commodities produced in the State and ranked second in importance to crude oil. Coal output from leases on Federal lands generated about $\$ 31$ million in royalties, which were equally shared by the State and Federal Governments.

Colorado's coal occurs in scattered regions that underlie more than one-fourth of the State. All ranks of coal are present, from lignite to anthracite. Current production, however, consists of slightly more than half bituminous coal and the rest subbituminous coal. Some of the bituminous coal was produced for use in making metallurgical coke. Since 1983, when the State's only iron and steel operation closed, all the coking coal mined in Colorado has been shipped out of State. Of the more than 20 coalbeds mined in 1992, the leading sources of production were the Wadge and D coalbeds and coalbeds in the Williams Fork Formation.

Coal was mined commercially in the Denver region in the early 1860 's, first for domestic heating and then later for use in blast furnaces. With the expansion of the railroads, Colorado's coal output became the largest in the West in the 1900's. Production reached about 12 million short tons by 1920 . It declined during the Depression, rose during World War II, only to drop again as markets were lost to natural gas and to the replacement of coal-burning locomotives with dieselpowered locomotives. A strong rise in the State's annual coal production began in the 1970 's. This was due mainly to the opening of several large underground and surface mines to meet a growing demand from electric utilities for the low-sulfur coal present in the State. Colorado's coal output was 19 million short tons in 1992.

Early coal mining in Colorado was almost exclusively by underground methods. Surface mining in the State began in 1909 in Jackson County. The amount of surface-mined coal increased gradually, rising to account for more than half of Colorado's annual coal output in most of the 1970's, all of the 1980's, and slightly less than half in recent years. The largest coal mine in Colorado in 1992, with production of more than 4 million short tons, was the Colowyo surface mine of Colowyo Coal Company, in Moffatt County. Moffatt and Routt counties were the major coal producers. About two-thirds of Colorado's 1992 coal production was from Federal leases.

Less than two-thirds of the coal shipped from Colorado's mines in 1992 was to consumers in the State. Texas and Utah were the principal out-of-State destinations. Most of the coal was for electric utilities. The small amount of coking coal produced was shipped to Utah and Illinois. Some coal was also exported overseas.

Electric utilities accounted for nearly all of the 17 million short tons of coal consumed in Colorado in 1992. The State's mines supplied more than two-thirds of the utility coal, with Wyoming coal making up the balance. Colorado's largest coal-fired generating units, totaling 1,264 megawatts, are in the Craig plant of Colorado-Ute Electric Association, Inc., in Moffat County. Of the coal used in other sectors, malt beverage manufacturing and cement plants were the largest consumers. 


\section{Colorado}

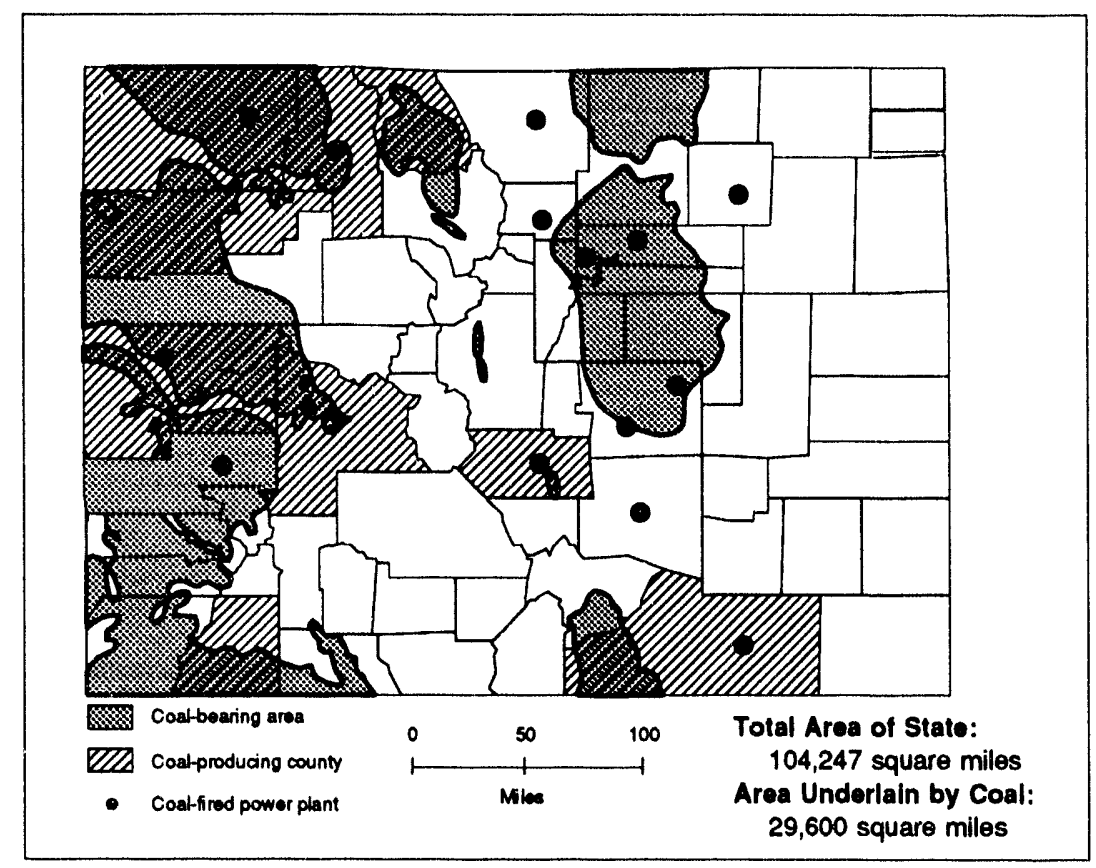

Coal Production, 1890-1992

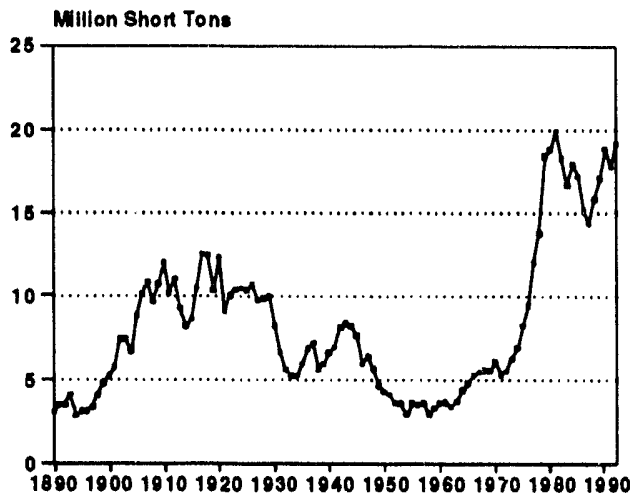

\section{Coal Reserves (Million Short Tons)}

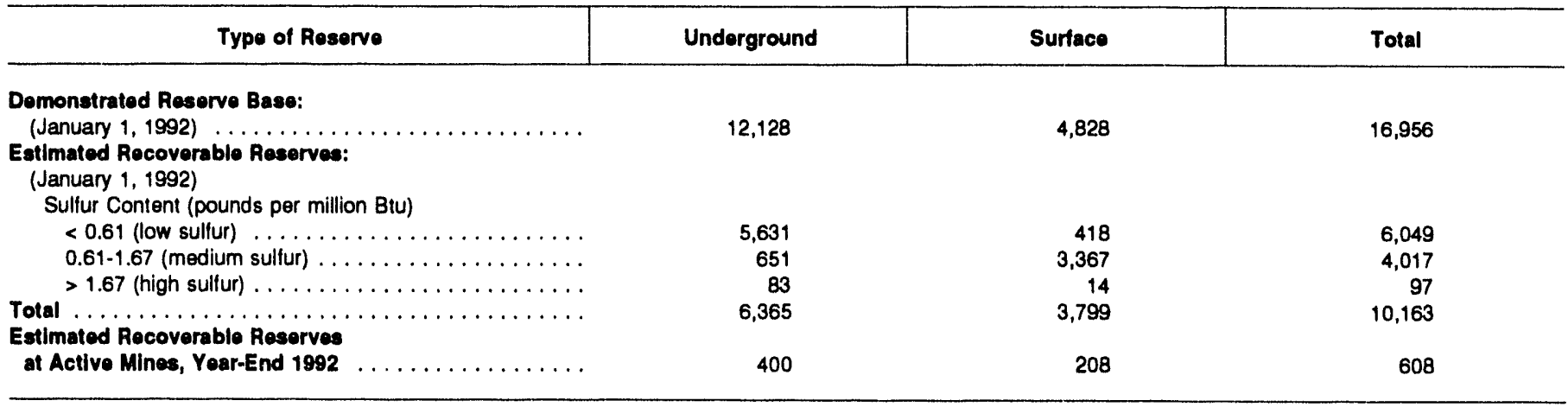

\section{Production}

\begin{tabular}{|c|c|c|c|c|c|}
\hline Sallent Data by Mine Type & 1980 & 1985 & 1890 & 1991 & 1992 \\
\hline \multicolumn{6}{|l|}{ Underground } \\
\hline Quantity (thousand short tons) $\ldots \ldots \ldots \ldots \ldots \ldots$ & 5,721 & 6,377 & 10,628 & 9,601 & 10,246 \\
\hline Mines $\ldots \ldots \ldots \ldots \ldots \ldots \ldots \ldots \ldots \ldots \ldots$ & 26 & 23 & 16 & 16 & 15 \\
\hline 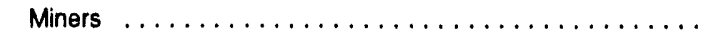 & 2,408 & 1,464 & 1,509 & 1,530 & 1,085 \\
\hline Productivity (short tons per miner per hour) $\ldots \ldots \ldots \ldots \ldots$ & 1.18 & 2.16 & 3.26 & 4.23 & 4.52 \\
\hline Average Mine Price (dollars per short ton) $\ldots \ldots \ldots \ldots \ldots$ & 27.24 & 28.91 & 24.27 & 24.09 & 21.80 \\
\hline \multicolumn{6}{|l|}{ Surface } \\
\hline Quantity (thousand short tons) $\ldots \ldots \ldots \ldots \ldots \ldots$ & 13,125 & 10,865 & 8,281 & 8,233 & 8,981 \\
\hline 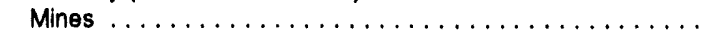 & 17 & 12 & 7 & 5 & 6 \\
\hline Miners $\ldots \ldots \ldots \ldots \ldots \ldots \ldots \ldots \ldots \ldots$ & 1,503 & 1,087 & 500 & 507 & 525 \\
\hline Productivity (short tons per miner per hour) $\ldots \ldots \ldots \ldots$ & 3.94 & 4.78 & 6.86 & 6.51 & 6.52 \\
\hline Average Mine Price (dollars per short ton) $\ldots \ldots \ldots \ldots \ldots$ & 16.43 & 22.16 & 18.53 & 19.96 & 20.80 \\
\hline \multicolumn{6}{|l|}{ Total } \\
\hline Quantity (thousand short tons) & 18,846 & 17,243 & 18,910 & 17,834 & 19,226 \\
\hline Mines $\ldots \ldots \ldots \ldots \ldots \ldots \ldots \ldots \ldots \ldots \ldots \ldots$ & 43 & 35 & 23 & 21 & 21 \\
\hline 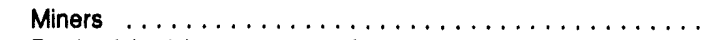 & 3,911 & 2,551 & 2,009 & 2,037 & 1,610 \\
\hline Productivity (short tons per miner per hour) $\ldots \ldots \ldots \ldots \ldots$ & 2.26 & 3.30 & 4.24 & 5.05 & 5.27 \\
\hline Average Mine Price (dollars per short ton) $\ldots \ldots \ldots \ldots \ldots$ & 19.89 & 24.65 & 21.75 & 22.18 & 21.33 \\
\hline
\end{tabular}




\section{Colorado}

Number of Mines by Production Range and Percent of Production, 1992

\begin{tabular}{|c|c|c|c|c|c|c|c|c|}
\hline \multirow{3}{*}{ Mine Type } & \multicolumn{8}{|c|}{ Production Rango (thousand short tons) } \\
\hline & \multicolumn{2}{|c|}{1,000 and over } & \multicolumn{2}{|c|}{50010999} & \multicolumn{2}{|c|}{100 to 499} & \multicolumn{2}{|c|}{$<100$} \\
\hline & Number & Percent & Number & Percent & Number & Percent & Number & Percent \\
\hline Underground & 4 & 71 & 2 & 13 & 5 & 16 & 4 & $<1$ \\
\hline Surface $\ldots \ldots \ldots$ & 3 & 92 & 0 & 0 & 2 & 8 & 1 & $<1$ \\
\hline All Mines $\ldots \ldots \ldots \ldots \ldots \ldots$ & 7 & 80 & 2 & 7 & 7 & 12 & 5 & 1 \\
\hline
\end{tabular}

\section{Coal Demand}

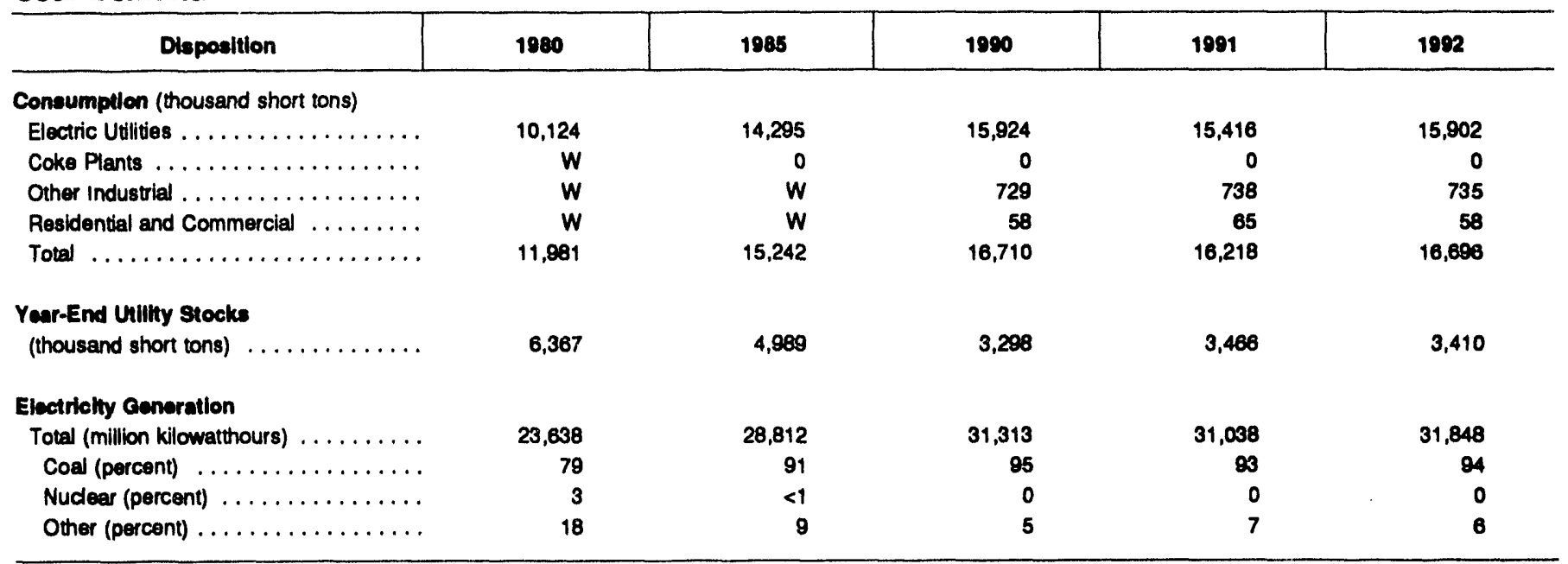

\section{Utillity Coal Data, 1992}

\begin{tabular}{|c|c|c|}
\hline Average Quality and Average Dellvored Cost & Produced In State & Rocelpte, All Sources \\
\hline Heat Content (million Btu per short ton) $\ldots \ldots \ldots \ldots \ldots \ldots$ & 21.57 & 19.84 \\
\hline Sulfur Content (percent by weight) $\ldots \ldots \ldots \ldots \ldots \ldots \ldots$ & .42 & .38 \\
\hline Ash Content (percent by weight) $\ldots \ldots \ldots \ldots \ldots \ldots \ldots$ & 8.26 & 7.01 \\
\hline Pounds of Sulfur per million Bru $\ldots \ldots \ldots \ldots \ldots \ldots \ldots$ & .39 & .38 \\
\hline Dollars per million Btu $\ldots \ldots \ldots \ldots \ldots \ldots \ldots \ldots \ldots \ldots$ & 1.37 & 1.09 \\
\hline Dollars per short ton $\ldots \ldots \ldots \ldots \ldots \ldots \ldots \ldots \ldots$ & 29.51 & 21.67 \\
\hline
\end{tabular}

Estimated Total State Enorgy Consumption, 1901: 964 trillion Btu (coal, 322; natural gas, 268; petroleum, 345; nuclear electric power, 0; hydroelectric power, 17; other, 0 ; net interstate flow of electriclty and asecclated losees, 12).

$W=$ Withheld to avoid disclosure of individual company data.

Notes: Totals may not equal sum of components because of independent rounding. Data coverage-Production: all mines. Number of mines: 1980, mines that produced 10,000 short tons or more; other years, all mines. Number of minere and productlvity: mines that produced 10,000 or more short tons and preparation plants that had 5,000 or more employee hours. Averege mine prlce: mines that produced 10,000 or more short tons. Average qualthy and average dellvered cout of utility coal power plants with a generator nameplate capacity of 50 megawatts or more. Extent of coal-bearing areas and locations of coal-consuming plants shown on map are approximate; small coal deposits are not shown. Coal-producing counties shown on map exclude any county where all 1992 output was from mines producing less than 10,000 short tons.

Sources: Energy Information Administration-U.S. Coal Reserves: An Update by Heat and Sultur Content, February $1993 ;$ Coal Production 1992 and prior issues; Coal Data: A Reference; Quarterly Coal Report October-December 1992 and prior issues; Electric Power Annual 1991 and prior issues; Electric Power Monthly, March 1993; Cost and Quality of Fuels for Electric Power Plants 1992; Inventory of Power Plants in the United States 1992; State Energy Data Report 1991: Consumption Estimates; Map of coal-bearing areas is based mainly on U.S. Geological Survey map, Coalfields of the United States, 1960. Data for historical graph 1890-1975, U.S. Department of the Interior, Geological Survey and Bureau of Mines (Minerals Yearbook and annual predecessor Mineral Resources of the United States); 1976 forward, Energy Information Administration, Coal Production 1992 and prior issues. 


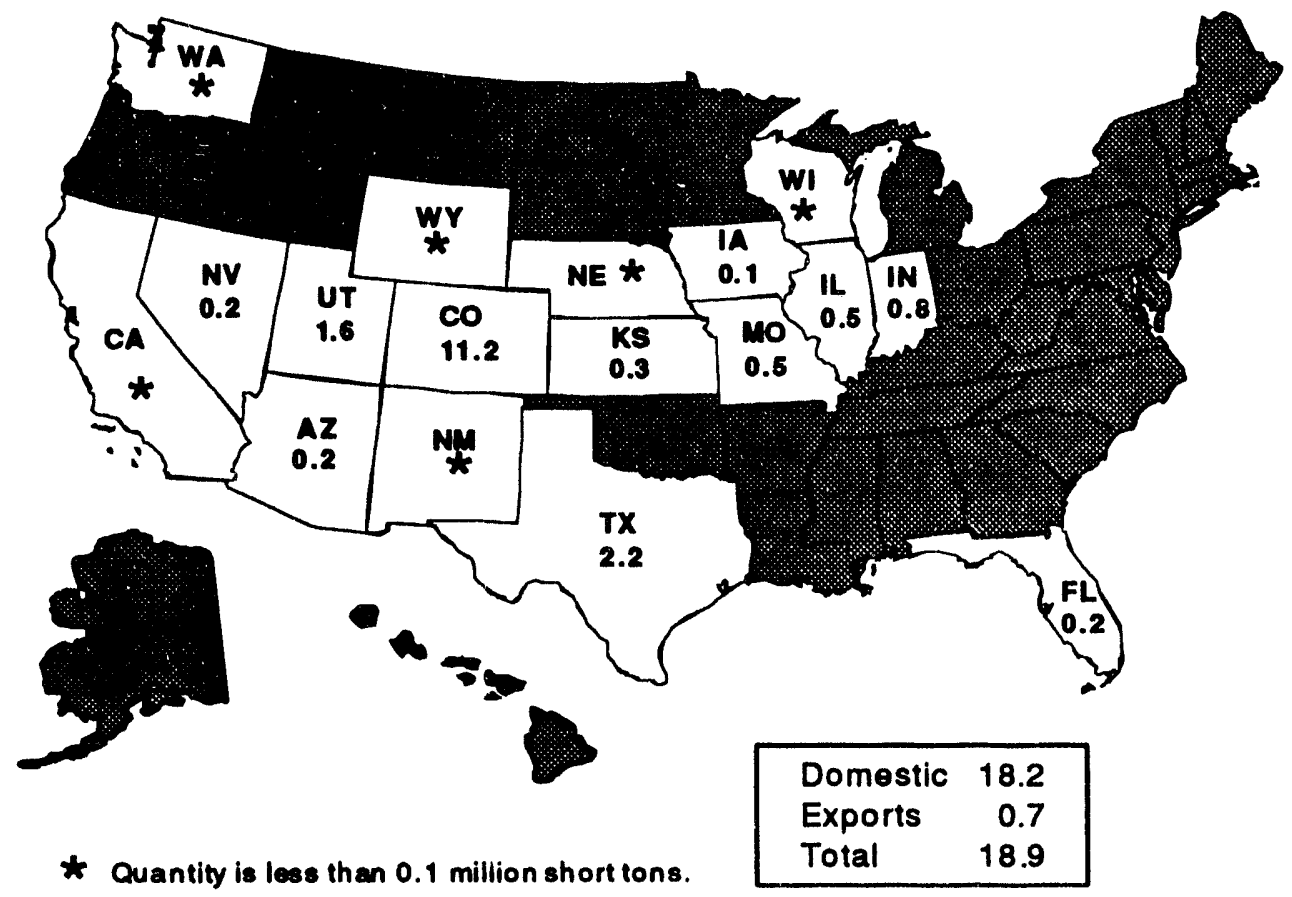

Transportation modes, domestic markets (percent): rail, 75; water, 1; truck, 23; unknown, < 1 .

Note: Total may not equal sum of components because of independent rounding.

Source: Energy Information Administration, Form EIA-6, "Coal Distribution Report."

Origin of Coal Recelved in Colorado, 1992

(Million Short Tons)

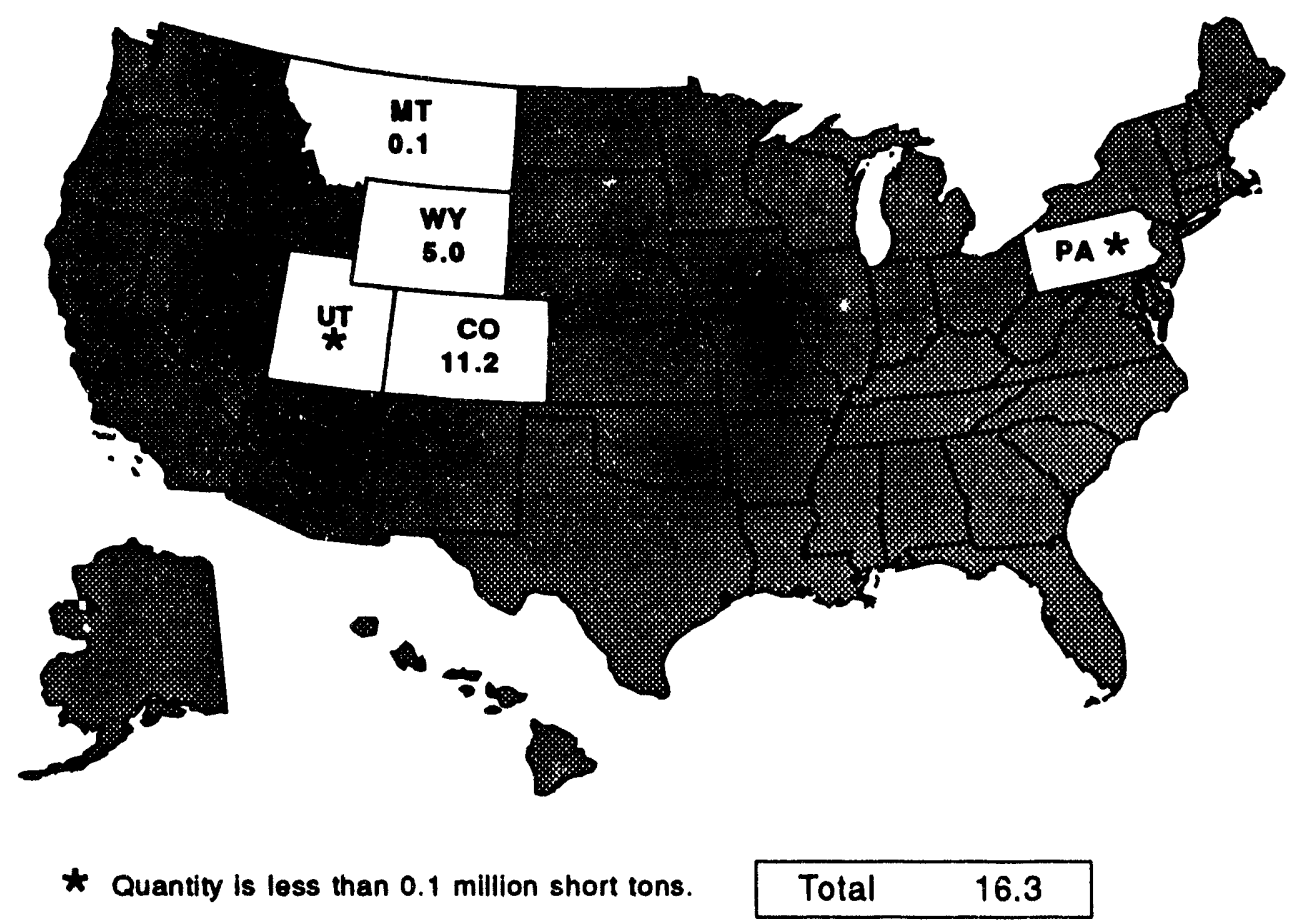

Note: Total may not equal sum of components because of independent rounding.

Source: Energy Information Administration, Form EIA-6, "Coal Distribution Report." 


\section{State Coal Profile: Illinois}

Coal is the most valuable mineral resource in Illinois. Coal production in recent years has accounted for about 60 percent of the estimated total value of all mineral production in the State, including crude oil and natural gas.

Coal is abundant in Illinois, underlying two-thirds of the State in a large geologic depression called the Illinois Basin. The minable coalbeds are relatively thick, generally flat-lying, and continuous over extensive areas. Illinois coal is bituminous in rank and has a high sulfur content, a characteristic that hampers its use because of environmental concerns for air quality. Even when cleaned, the sulfur content is high, averaging 2 to 3 percent (by weight). The major coalbed among the eight mined in 1992 was the No. 6 (also known as the "Herrin"), which averages more than 6 feet in thickness. Some coal produced in the State is suitable for conversion into metallurgical coke.

Coal was first reported in what is now Illinois by French-Canadian explorers who noted an outcrop along the Illinois River on a map made in the 1670's, recording for the first time the presence of coal in what is now the United States. Coal production began in the State in the early 1800 's and, spur red by industrial development and railroad expansion, rose to an all-time high of 89 million short tons in 1918. Afterwards, coal output went into a general decline, dropping markedly during the Depression. It rose to meet the demands of World War II, but later decreased due to competition from oil and gas and the conversion of railroad locomotives from coal to diesel-electric power. Beginning around 1960, increased demand for utility coal raised the production level. Since then, however, the demand for Illinois coal has been constrained because of such factors as the enactment of clean air standards, a decline in the demand for coking coal, and the development of nuclear electric power in the State. In recent years, about 60 million short tons of coal have been produced annually in Illinois.

About two-thirds of the coal produced in Illinois since 1980 was from underground mines, historically the chief source of production. Most of the mines are very large operations, producing at an annual rate exceeding 1 million short tons each. The largest mine in 1992, producing over 3 million short tons, was the Captain surface mine of Arch of Illinois, in Perry County. Over 95 percent of the State's coal output is cleaned. The Captain coal preparation plant, near Percy, is the second-largest coal-cleaning facility in the United States, with a processing capacity of 2,850 short tons per hour. Perry, Saline, and Franklin Counties were the State's leading coal producers.

More than two-thirds of the coal prculuced in Illinois in 1992 was shipped out of State, chiefly to Missouri and Indiana. About 1 million short tons of Illinois coal was exported to overseas markets. About 80 percent of the 32 million short tons of coal consumed in Illinois in 1992 was used to generate electricity. Nearly 60 percent of the utility coal was from Illinois, with most of the balance being low-sulfur coal from Wyoming and Montana. The largest coal-fired generating facility in Illinois is the 1,680-megawatt Baldwin plant of Illinois Power Company, in Randolph County. Metallurgical coke was made from coal received from West Virginia, Virginia, and Kentucky. Other coal-consuming industries were largely manufacturers of food, chemical products, and cel ent. 


\section{IIIInJis}
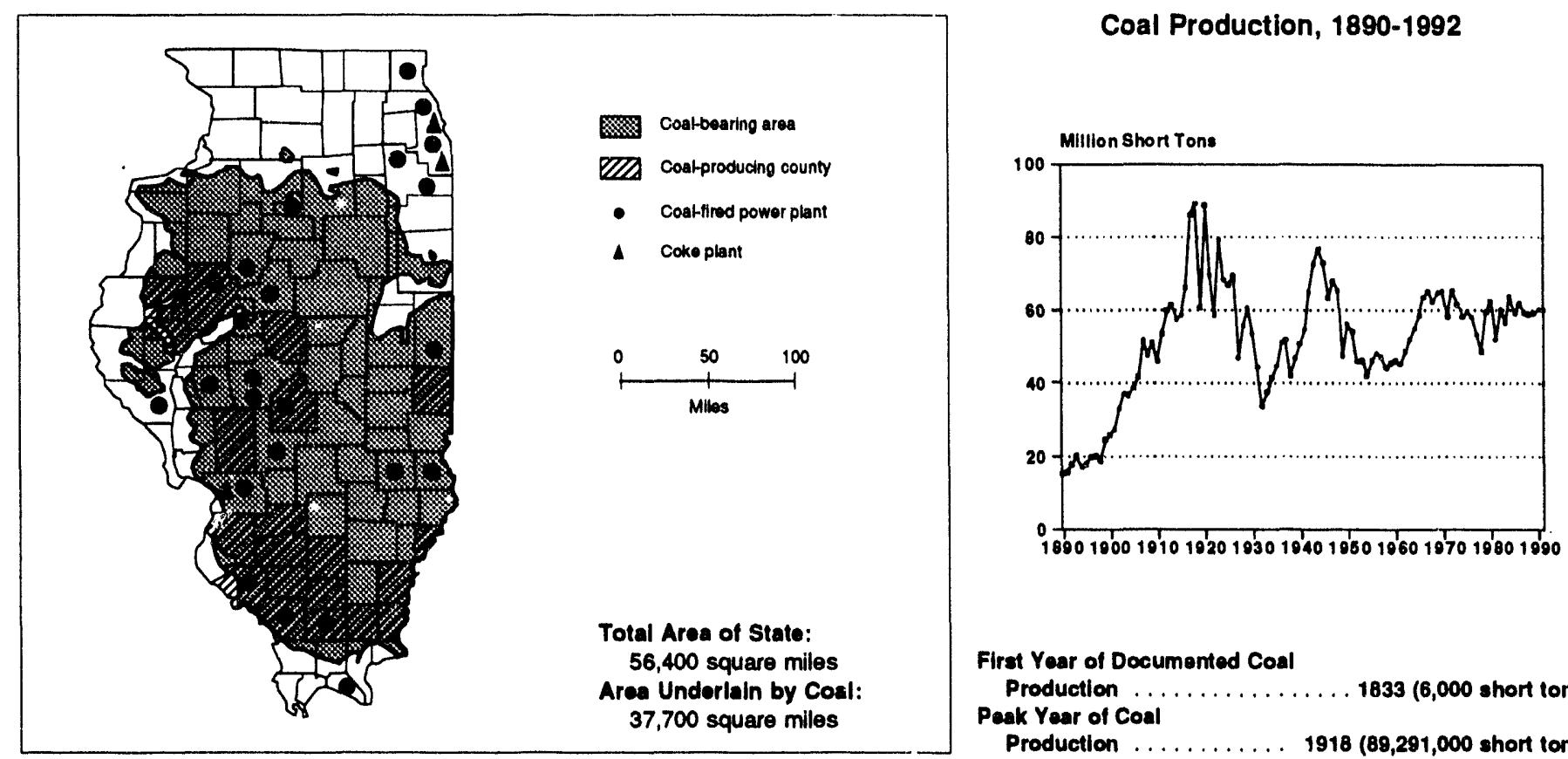

\section{Coal Reserves (Million Short Tons)}

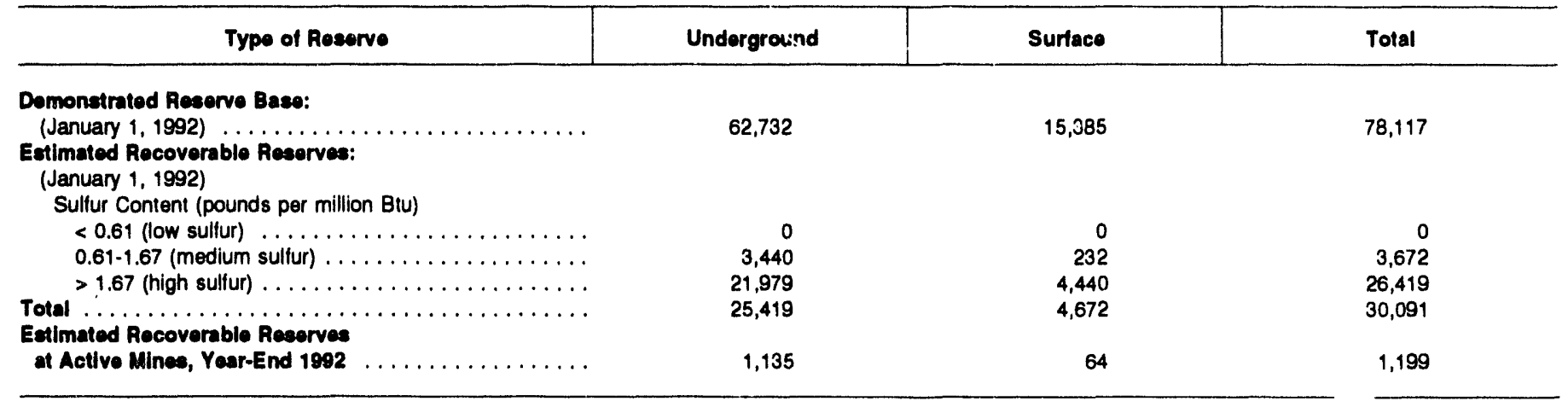

\section{Production}

\begin{tabular}{|c|c|c|c|c|c|}
\hline Sallent Data by Mine Type & 1980 & 1985 & 1980 & 1991 & 1992 \\
\hline \multicolumn{6}{|l|}{ Underground } \\
\hline Quantity (thousand short tons) $\ldots \ldots \ldots \ldots \ldots \ldots \ldots$ & 34,969 & 37,343 & 41,671 & 43,134 & 46,965 \\
\hline Mines $\ldots \ldots \ldots \ldots \ldots \ldots \ldots \ldots \ldots \ldots \ldots \ldots$ & 31 & 34 & 28 & 33 & 29 \\
\hline 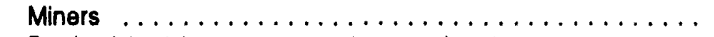 & 12,610 & 10,349 & 7,407 & 7,056 & 6,780 \\
\hline Productivity (shon tons per miner per hour) . . . . . . . . . & 1.49 & 1.92 & 2.70 & 2.88 & 3.21 \\
\hline Average Mine Price (dollars per short ton) . . . . . . . . . . & 25.58 & 31.78 & 28.30 & 29.05 & 27.93 \\
\hline \multicolumn{6}{|l|}{ Surface } \\
\hline Quantity (thousand short tons) $\ldots \ldots \ldots \ldots \ldots \ldots$ & 27,574 & 21,858 & 18,722 & 17,124 & 12,892 \\
\hline Mines $\ldots \ldots \ldots \ldots \ldots \ldots \ldots \ldots \ldots \ldots \ldots \ldots$ & 28 & 20 & 17 & 18 & 14 \\
\hline 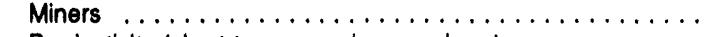 & 5,125 & 3,509 & 2,611 & 2,046 & 1,543 \\
\hline Productivity (short tons per miner per hour) . . . . . . . . . & 2.70 & 2.69 & 3.64 & 4.30 & 4.47 \\
\hline Average Mine Price (dollars per short ton) $\ldots \ldots \ldots \ldots \ldots$ & 22.86 & 29.14 & 26.45 & 26.59 & 26.69 \\
\hline \multicolumn{6}{|l|}{ Total } \\
\hline Quantity (thousand short tons) & 62,543 & 59,201 & 60,393 & 60,258 & 59,857 \\
\hline 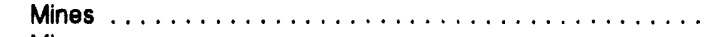 & 59 & 54 & 45 & 51 & 43 \\
\hline 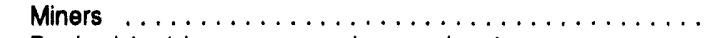 & 17,735 & 13,858 & 10,018 & 9,102 & 8.323 \\
\hline Productivity (shon tons per miner per hour) $\ldots \ldots \ldots \ldots \ldots$ & 1.86 & 2.14 & 2.94 & 3.18 & 3.42 \\
\hline Average Mine Price (dollars per short ton) . . . . . . . . . . & 24.39 & 30.80 & 27.73 & 28.35 & 27.66 \\
\hline
\end{tabular}




\section{IIIInois}

Number of Mines by Production Range and Percent of Production, 1992.

\begin{tabular}{|c|c|c|c|c|c|c|c|c|c|}
\hline \multirow{3}{*}{ Mine Type } & & \multicolumn{8}{|c|}{ Production Range (thousand short tons) } \\
\hline & & \multicolumn{2}{|c|}{1,000 and over } & \multicolumn{2}{|c|}{500 to 999} & \multicolumn{2}{|c|}{100 to 499} & \multicolumn{2}{|c|}{$<100$} \\
\hline & & Number & Percent & Number & Percent & Number & Percent & Number & Percent \\
\hline \multirow{3}{*}{\multicolumn{2}{|c|}{ 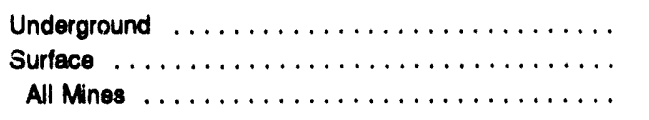 }} & 23 & 94 & 3 & 5 & 1 & $<1$ & 2 & $<1$ \\
\hline & & 4 & 70 & 4 & 20 & 3 & 9 & 3 & 1 \\
\hline & & 27 & 89 & 7 & 9 & 4 & 2 & 5 & $<1$ \\
\hline \multicolumn{10}{|l|}{ Coal Demand } \\
\hline Disposition & \multicolumn{2}{|l|}{1980} & \multicolumn{2}{|l|}{1985} & 1990 & \multicolumn{2}{|r|}{1991} & \multicolumn{2}{|c|}{1992} \\
\hline \multicolumn{10}{|l|}{ Consumption (thousand short tons) } \\
\hline Electric Utilites . . . . . . . . . . . . . & \multicolumn{2}{|c|}{34,610} & \multicolumn{2}{|l|}{31,608} & 27,396 & \multicolumn{2}{|r|}{27,754} & \multicolumn{2}{|c|}{25,338} \\
\hline Coke Plants $\ldots \ldots \ldots \ldots \ldots \ldots$ & \multicolumn{2}{|c|}{1,810} & \multicolumn{2}{|l|}{2,358} & W & \multicolumn{2}{|r|}{ w } & \multicolumn{2}{|c|}{ w } \\
\hline Other Industrial $\ldots \ldots \ldots \ldots \ldots \ldots$ & \multicolumn{2}{|c|}{3,265} & \multicolumn{2}{|l|}{ 3,399 } & 3,888 & \multicolumn{2}{|r|}{4,426} & \multicolumn{2}{|c|}{3,839} \\
\hline Residential and Commercial $\ldots \ldots \ldots$ & \multicolumn{2}{|c|}{155} & \multicolumn{2}{|l|}{236} & $w$ & \multicolumn{2}{|r|}{$w$} & \multicolumn{2}{|r|}{$w$} \\
\hline Total $\ldots \ldots \ldots \ldots \ldots \ldots \ldots \ldots$ & \multicolumn{2}{|c|}{39,840} & \multicolumn{2}{|l|}{37,601} & 33,904 & \multicolumn{2}{|r|}{34,677} & \multicolumn{2}{|c|}{31,776} \\
\hline \multicolumn{10}{|l|}{ Year-End Uility Stocks } \\
\hline (thousand short tons) $\ldots \ldots \ldots \ldots \ldots$ & 11,68 & & 6,977 & & 7,398 & & 6,977 & & 399 \\
\hline Electriclty Generation & & & & & & & & & \\
\hline Total (million kilowatthours) . . . . . . . . & 103,42 & & 103,667 & & 126,977 & & 127,851 & & 837 \\
\hline Coal (percent) $\ldots \ldots \ldots \ldots \ldots \ldots$ & & 35 & 61 & & 42 & & 42 & & 40 \\
\hline Nuclear (percent) $\ldots \ldots \ldots \ldots \ldots \ldots$ & & 27 & 38 & & 57 & & 56 & & 59 \\
\hline Other (percent) $\ldots \ldots \ldots \ldots \ldots \ldots$ & & 8 & 1 & & 1 & & 2 & & 1 \\
\hline
\end{tabular}

\section{Utility Coal Data, 1992}

\begin{tabular}{|c|c|c|}
\hline Average Quality and Avorage Delivered Cost & Produced in Stato & Rocelpts, All Sources \\
\hline Heat Content (million Btu per short ton) $\ldots \ldots \ldots \ldots \ldots \ldots$ & 22.51 & 21.33 \\
\hline Sulfur Content (percent by weight) $\ldots \ldots \ldots \ldots \ldots \ldots \ldots \ldots$ & 2.63 & 1.91 \\
\hline Ash Content (percent by weight) $\ldots \ldots \ldots \ldots \ldots \ldots \ldots \ldots$ & 9.33 & 8.19 \\
\hline Pounds of Sulfur per million Btu $\ldots \ldots \ldots \ldots \ldots \ldots \ldots \ldots$ & 2.34 & 1.79 \\
\hline Dollars per million Btu $\ldots \ldots \ldots \ldots \ldots \ldots \ldots \ldots \ldots \ldots$ & 1.58 & 1.74 \\
\hline Dollars per short ton $\ldots \ldots \ldots \ldots \ldots \ldots \ldots \ldots \ldots$ & 35.52 & 37.06 \\
\hline
\end{tabular}

Estimated Total State Enorgy Consumption, 1991: 3,513 trillion Btu (coal, 758; natural gas, 1,006; potroleum, 1,111; nuclear ulectric power, 772; hydroelectric power, 1; other, 0 ; not interstate flow of electriclty and associated lossces, -134).

W = Withheid to avoid disclosure of individual company data.

Notes: Totals may not equal sum of components because of Independent rounding. Data coverage-Productlon: all mines. Number of mines: 1980 , mines that produced 10,000 short tons or more; other years, all mines. Number of miners and productivlty: mines that produced 10,000 or more short tons and preparation plants that had 5,000 or more employee hours. Average mine price: mines that produced 10,000 or more short tons. Average quality and average dellvered coet of utility coal: power plants with a generator nameplate capacity of 50 megawatts or more. Extent of coal-bearing areas and locations of cosl-consuming plants shown on map are approximate; small coal deposits are not shown. Coal-producing counties shown on map exclude any county where all 1992 output was from mines producing less than 10,000 short tons.

Sources: Energy Information Administration-U.S. Coal Ruserves: An Update by Heat and Sulfur Content, February 1993 ; Coal Production 1992 and prior issues; Coal Data: A Reference; Quarterly Coal Report October-December 199:? and prior issues; Electric Power Annual 1991 and prior issues; Electric Power Monthly, March 1993; Cost and Quality of Fuels for Electric Power Plants 1992; Inventory of Power Plants in the United S. 'tes 1992; State Energy Data Report 1991: Consumption Estimates: Map of coal-bearing areas is based mainly on U.S. Geological Survey map, Coatfields of the United States, 1960. Data for historical graph 1890-1975, U.S. Department of the Interior, Geological Survey and Bureau of Mines (Minerals Yearbook and annual predecessor Mineral Resources of the United States); 1976 forward, Energy Information Administration, Coal Production 1992 and prior issues. 
Destination of Coal Produced In IIIInols, 1992

(Million Short Tons)

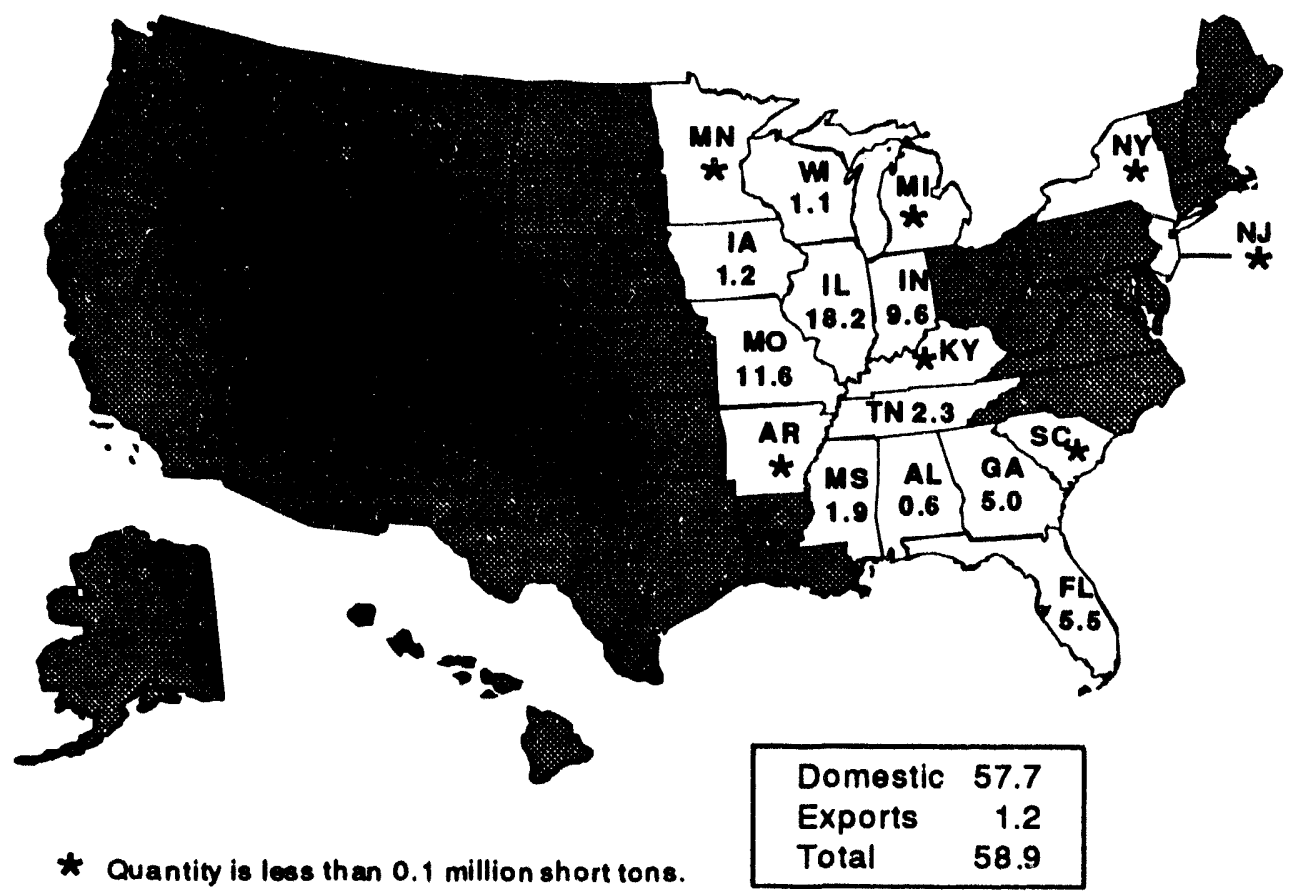

Transportation modes, domestic markets (percent): rail, 54; water, 35; truck, 8; tramway/conveyor, 3; unknown, < 1.

Note: - Jtal may not equal sum of components because of independent rounding.

Source: Energy Information Administration, Form EIA-6, "Coal Distribution Report."

\section{Origin of Coal Recelved in IIIInols, 1992}

(Million Short Tons)

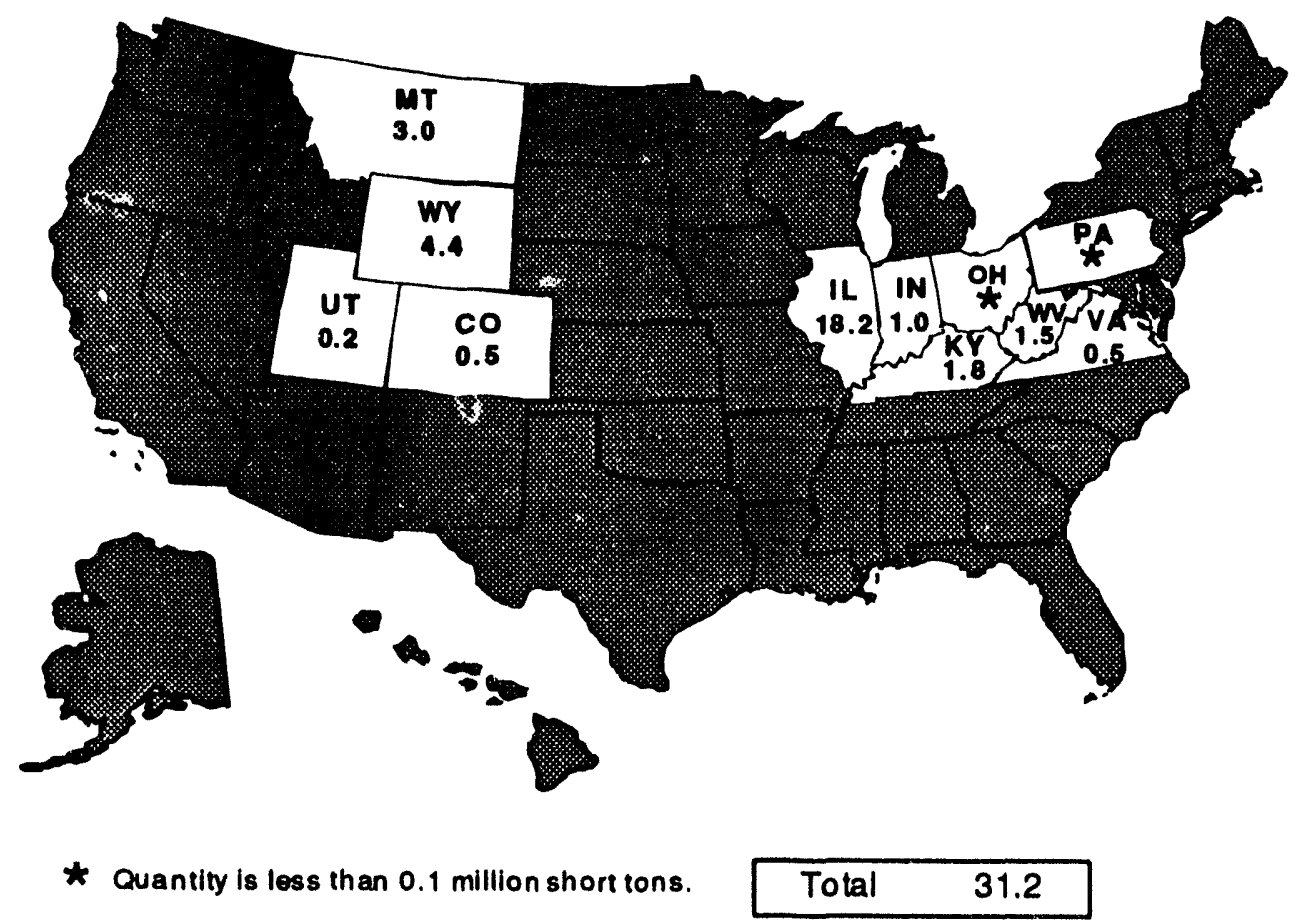

Note: Total may not equal sum of components because of independent rounding.

Source: Energy Information Administration, Form EIA-6, "Coal Distribution Report." 


\section{State Coal Profile: Indiana}

Indiana's mineral wealth lies mostly in its coal deposits, located in a triangular area in the southwestern part of the State. In 1992, coal production from the area accounted for an estimated 60 percent of the total value of all mineral production in Indiana.

The Indiana coalfield composes the eastern part of the Illinois Basin, a large geologic depression that also underlies parts of Illinois and Kentucky. The coalbeds, which average more than 4 feet in thickness, are exposed or at shallow depths in the eastern part of the field and gradually become deeper westward. The use of Indiana's coal, all bituminous in rank, is environmentally handicapped by its high sulfur content, which averages more than 2 percent by weight. Production in 1992 was from about 15 coalbeds. The principle beds were the No. VI and No. V, which average about 5 feet in thickness.

Coal was first discovered in Indiana along the Wabash River in 1736. By 1832, coal was being advertised for sale, and in 1837, the first coal company was officially incorporated and granted a charter by the State. By 1840 , coal was being shipped on flatboats on the Wabash and other rivers. Indiana's coal output totaled more than 6 million short tons in 1900, rose to 31 million short tons during World War I, and then declined because of the Depression and competition from petroleum. Production increased to 28 million short tons during World War II, only to slump afterwards as many consumers switched to oil and natural gas and the railroads replaced coal-burning locomotives with dieselelectric locomotives. In the 1960 's, an increased demand for utility coal spurred production. A record of 38 million short tons was produced in 1984 as utilities built up stockpiles, spurring production, in anticipation of a major coal miners' strike. Production has since declined and, in 1992, was 30 million short tons.

Nearly all of Indiana's coal production is from surface mining, which began in the State in 1918. The amount of surface-mined coal has increased almost steadily, and by the 1940's it usually exceeded the tonnage from underground mines. The State's largest producer in 1992, with about 3 million short tons, was the Old Ben No. 1 surface mine of Zeigler Coal Company, in Pike County. Warrick, Sullivan, Daviess, and Pike counties were the leading sources of Indiana's coal production.

About three-fourths of the coal produced in Indiana in 1992 was for consumption in the State. Out-of-State shipments were mostly to power plants in Kentucky, Wisconsin, and Illinois. In 1992, Indiana's coal consumption totaled 59 million short tons, ranking it the second-largest coal-consuming State after Texas. Most of the coal consumed in Indiana was used to generate electricity. More than $\mathbf{4 0}$ percent of the utility coal was from mines in Indiana, with Wyoming and Illinois supplying most of the balance. Indiana's largest coalburning generating facility, with 3,140 megawatts, is the Gibson plant of Public Service Company of Indiana, in Gibson County. This is the third-largest coal-fired power plant in the United States. Indiana's coke plants carbonize coal produced mostly from West Virginia, Virginia, and Kentucky; none of the coal was from Indiana. In 1992, Indiana's coke output was the Nation's second largest, following Pennsylvania. Most of the coal consumed by other industries was used as a source of heat by manufacturers of aluminum and steel. 


\section{Indlana}

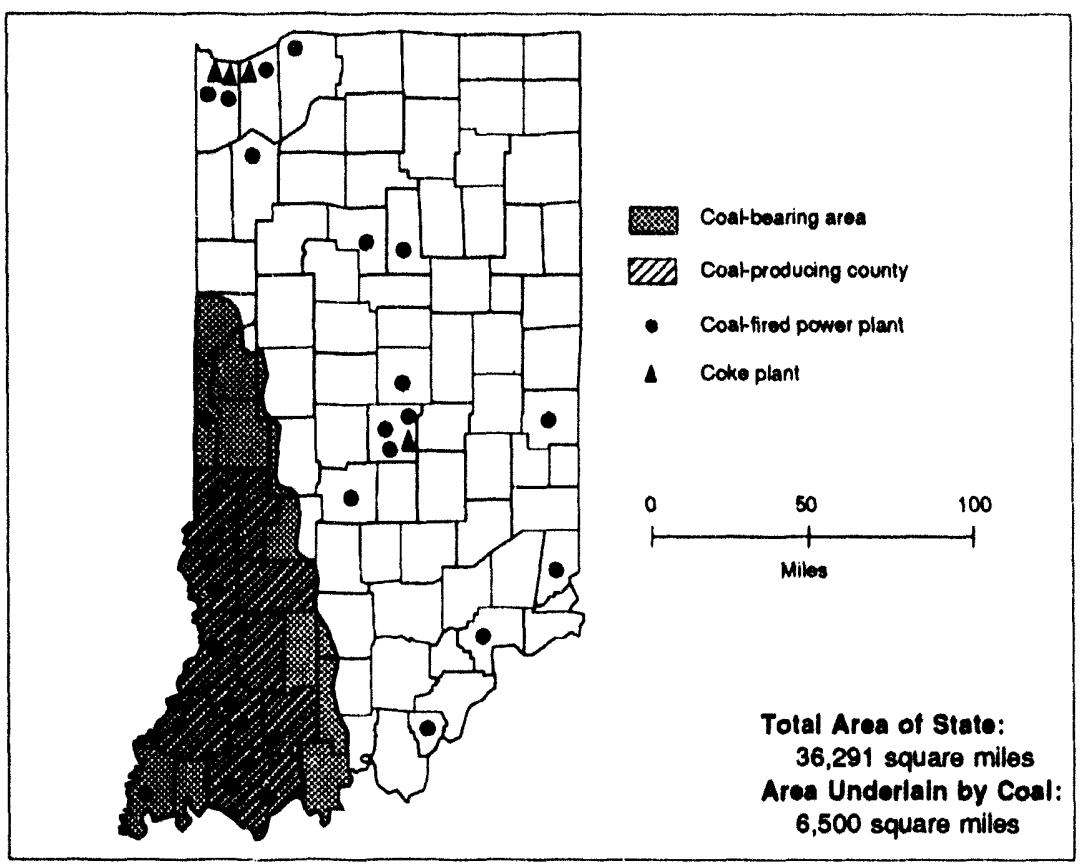

Coal Production, 1890-1992

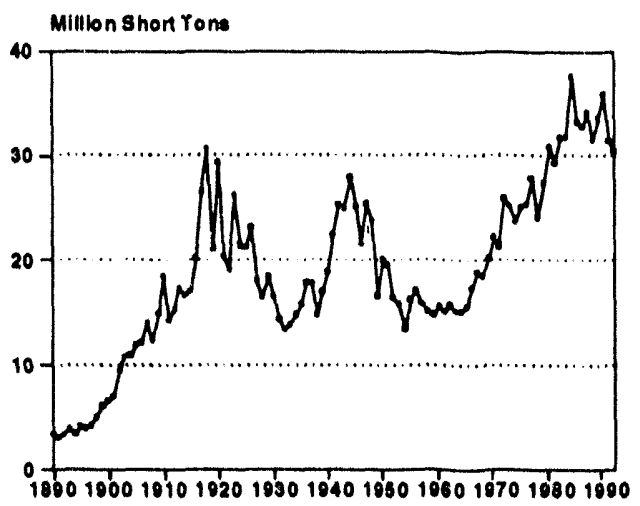

First Year of Documented Coal

Production . . . . . . . . . . . . 1840 (9,682 short tom) Peak Year of Coal

Production $1984(37,856,000$ shot tons $)$

\section{Coal Reserves (Million Short Tons)}

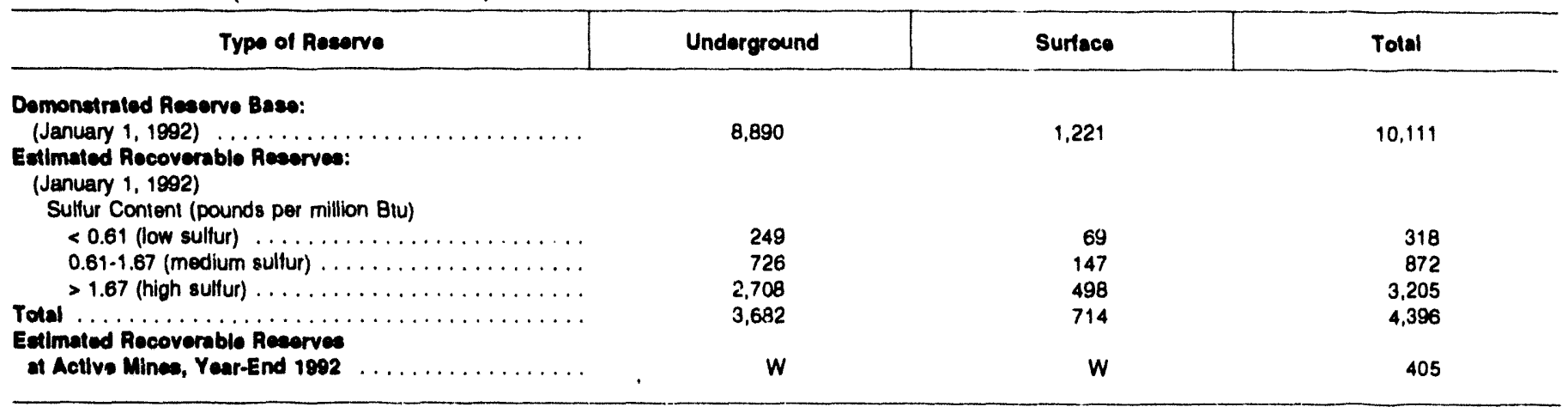

\section{Production}

\begin{tabular}{|c|c|c|c|c|c|}
\hline Sallent Data by Mine Type & 1980 & 1985 & 1990 & 1991 & 1992 \\
\hline \multicolumn{6}{|l|}{ Underground } \\
\hline Quantity (thousand short tons) $\ldots \ldots \ldots \ldots \ldots \ldots$ & 688 & 2,053 & 3,037 & 2,832 & 2,641 \\
\hline Mines $\ldots \ldots \ldots \ldots \ldots \ldots \ldots \ldots \ldots \ldots$ & 4 & 4 & 5 & 4 & 4 \\
\hline Miners $\ldots \ldots \ldots \ldots \ldots \ldots \ldots \ldots \ldots \ldots$ & 133 & 455 & 524 & 447 & 422 \\
\hline Productivity (short tons per miner per hour) $\ldots \ldots \ldots \ldots \ldots$ & 2.26 & 1.79 & 2.90 & 2.97 & 2.80 \\
\hline Average Mine Price (dollars per short ton) $\ldots \ldots \ldots \ldots \ldots$ & $W$ & 28.84 & $W$ & $W$ & $W$ \\
\hline \multicolumn{6}{|l|}{ Surtace } \\
\hline Quantity (thousand short tons) $\ldots \ldots \ldots \ldots \ldots \ldots$ & 30,185 & 31,262 & 32,870 & 28,636 & 27,825 \\
\hline Mines . . . . . . . . . $\ldots \ldots \ldots \ldots \ldots$ & 83 & 66 & 59 & 54 & 47 \\
\hline Miners $\ldots \ldots \ldots \ldots \ldots \ldots \ldots \ldots \ldots \ldots$ & 5,182 & 4,732 & 3,671 & 3,472 & 3,230 \\
\hline Productivity (short tons per miner per hour) $\ldots \ldots \ldots \ldots$ & 2.88 & 2.97 & 3.96 & 4.17 & 4.28 \\
\hline Average Mine Price (dollars per short ton) $\ldots \ldots \ldots \ldots \ldots$ & W & 26.39 & W & W & W \\
\hline \multicolumn{6}{|l|}{ Total } \\
\hline Quantity (thousand short tons) & 30,873 & 33,316 & 35,907 & 31,468 & 30,466 \\
\hline 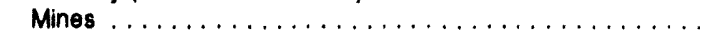 & 87 & 70 & 64 & 58 & 51 \\
\hline 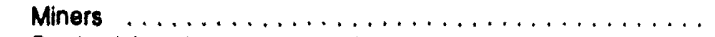 & 5,315 & 5,187 & 4,195 & 3,919 & 3,652 \\
\hline Productivity (short tons per miner per hour) $\ldots \ldots \ldots \ldots \ldots$ & 2.86 & 2.85 & 3.84 & 4.02 & 4.09 \\
\hline Average Mine Price (dollars per short ton) . . . . . . . . . . & 20.72 & 26.54 & 23.91 & 23.58 & 23.41 \\
\hline
\end{tabular}




\section{Indlana}

Number of Minea by Production Range and Percent of Production, 1992

\begin{tabular}{|c|c|c|c|c|c|c|c|c|c|}
\hline \multirow{3}{*}{ Mine Type } & & \multicolumn{8}{|c|}{ Production Range (thousand short tons) } \\
\hline & & \multicolumn{2}{|c|}{1,000 and over } & \multicolumn{2}{|c|}{500 to 999} & \multicolumn{2}{|c|}{100 to 499} & \multicolumn{2}{|c|}{$<100$} \\
\hline & & Number & Percent & Number & Percent & Number & Percent & Number & Percent \\
\hline Underground $\ldots \ldots \ldots$ & $\cdots$ & 1 & 42 & 1 & 31 & 2 & 27 & 0 & 0 \\
\hline Surface $\ldots \ldots \ldots \ldots \ldots \ldots \ldots \ldots$ & ... & 7 & 52 & 12 & 29 & 19 & 18 & 8 & 1 \\
\hline All Mines $\ldots \ldots \ldots$ & & 8 & 51 & 13 & 29 & 21 & 19 & 8 & 1 \\
\hline \multicolumn{10}{|l|}{ Coal Demand } \\
\hline Dlapoaition & \multicolumn{2}{|l|}{1980} & \multicolumn{2}{|c|}{1985} & 1990 & \multicolumn{2}{|r|}{1991} & \multicolumn{2}{|c|}{1992} \\
\hline \multicolumn{10}{|l|}{ Consumption (thousand short tons) } \\
\hline Electric Utillies $\ldots \ldots \ldots \ldots \ldots \ldots$ & \multicolumn{2}{|c|}{33,664} & \multicolumn{2}{|c|}{38,310} & 47,654 & \multicolumn{2}{|r|}{47,720} & \multicolumn{2}{|c|}{46,943} \\
\hline Coke Plants $\ldots \ldots \ldots \ldots \ldots \ldots$ & \multicolumn{2}{|c|}{11,909} & \multicolumn{2}{|c|}{9,338} & 8,887 & \multicolumn{2}{|r|}{8,234} & \multicolumn{2}{|c|}{7,153} \\
\hline$\ldots \ldots \ldots \ldots \ldots$ & \multicolumn{2}{|c|}{4,610} & \multicolumn{2}{|c|}{$\begin{array}{r}5,110 \\
524\end{array}$} & 4,629 & \multicolumn{2}{|r|}{4,404} & \multicolumn{2}{|c|}{4,260} \\
\hline Residential and Commercial $\ldots \ldots \ldots$ & \multicolumn{2}{|c|}{222} & \multicolumn{2}{|c|}{524} & 551 & \multicolumn{2}{|r|}{433} & \multicolumn{2}{|c|}{411} \\
\hline Total $\ldots \ldots \ldots \ldots$ & \multicolumn{2}{|c|}{50,485} & \multicolumn{2}{|c|}{53,291} & 61,701 & \multicolumn{2}{|r|}{60,790} & \multicolumn{2}{|c|}{58,767} \\
\hline \multicolumn{10}{|l|}{ Year-End Uillity stocks } \\
\hline (thouseand ahort tons) . . & 12,28 & & 11,3 & & 10,610 & & 9,953 & & 294 \\
\hline Electricliy Cenerution & & & & & & & & & \\
\hline Total (million kilowathours) . . . . . . . . & 70,61 & & 78,4 & & 97.738 & & 98,200 & & 304 \\
\hline$\ldots \ldots \ldots \ldots \ldots$ & & 99 & & & 98 & & 98 & & 98 \\
\hline Nuclear (percent) $\ldots \ldots \ldots \ldots \ldots$ & & 0 & & 0 & 0 & & 0 & & 0 \\
\hline Other (percent) $\ldots \ldots \ldots \ldots \ldots \ldots$ & & 1 & & 1 & 2 & & 2 & & 2 \\
\hline
\end{tabular}

Utility Coal Data, 1992

\begin{tabular}{|c|c|c|}
\hline Averege Qually and Average Dellvered Coat & Produced In State & Recolpte, All Sources \\
\hline Heat Content (million Btu per short ton) & 22.29 & 21.28 \\
\hline Sulfur Content (percent by weight) ....... & 2.46 & 1.88 \\
\hline Ash Content (percent by weight) $\ldots \ldots \ldots \ldots \ldots \ldots$ & 9.07 & 8.43 \\
\hline Pounds of Sulfur per million Bru $\ldots \ldots \ldots \ldots \ldots \ldots$ & 2.21 & 1.77 \\
\hline 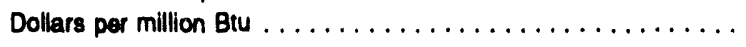 & 1.24 & 1.31 \\
\hline Dollars per short ton $\ldots \ldots \ldots \ldots \ldots \ldots \ldots \ldots \ldots \ldots \ldots \ldots$ & 27.68 & 27.89 \\
\hline
\end{tabular}

Estimated Total Stato Energy Consumption, 1901: 2,421 tillion Btu (coal, 1,340; natural gas, 464; potroleum, 806; nuclear olectric power, 0; hydroelectric power, 4; other, 0; net interstate flow of electricity and asececlated loseces, -193).

$W$ - Witheid to avoid disclosure of individual company data.

Notes: Tolab may not equal sum of components because of indopendent rounding. Data covorage-Production: all mines. Number of mines: 1980 , mines that produced 10,000 short tons or more; other years, all mines. Number of miners and productivity: mines that produced 10,000 or more shon tons and preparation plants that had 5,000 or more employee hours. Average mine prtce: mines that produced 10,000 or more short tons. Average quality and average dellivered coet of utility coal: power plants with a generator nameplate capacity of 50 megawatts or more. Extent of coal-bearing areas and locations of coal-consuming plants shown on map are approximate; small coal deposits are not shown. Coal-producing counties shown on map exclude any county where all 1992 output was from mines producing less than 10,000 short tons.

Sources: Energy Information Administration-U.S. Coal Reserves: An Update by Heat and Sultur Content, February 1993; Coal Production 1992 and prior issues; Coal Data: A Relerence; Quartenty Coal heport October-Decomber 1992 and prior issues; Electric Power Annual 1991 and prior issues; Electric Power Monthly, March 1993; Cost and Quality of Fuels for Electric Power Plants 1992; Inventory of Power Plants in the United States 1992; State Energy Data Report 1991: Consumption Estimates; Map of coal-bearing areas is based mainly on U.S. Geological Survey map, Coalfields of the United States, 1960. Data tor historical graph 1890-1975, U.S. Department of the Interlor, Geological Survey and Bureau of Mines (Minerals Yeartook and annual predecessor Mineral Resources of the United States); 1976 fonward, Energy Information Administration, Coal Production 1992 and prior issues. 
Destination of Coal Produced In Indlana, 1992

(Milion Short Tons)

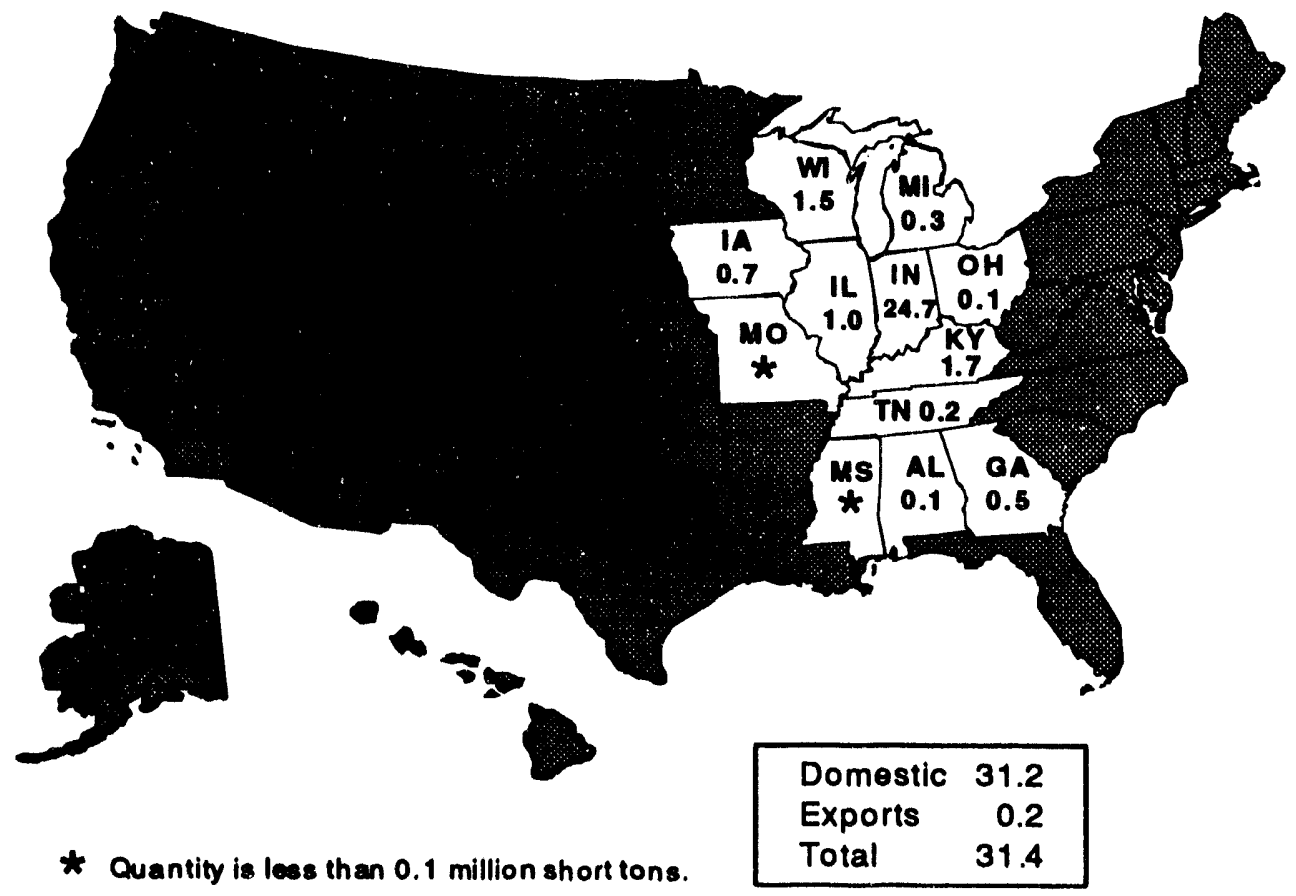

Transportation modes, domestic markets (percent): rail, 55; water, 16; truck, 27; tramway/conveyor, 2; unknown, $<1$.

Note: Total may not equal sum of components because of independent rounding.

Source: Energy Information Administration, Form EIA-6, "Coal Distribution Report."

Origin of Coal Recolved in Indlana, 1992

(Million Short Tons)

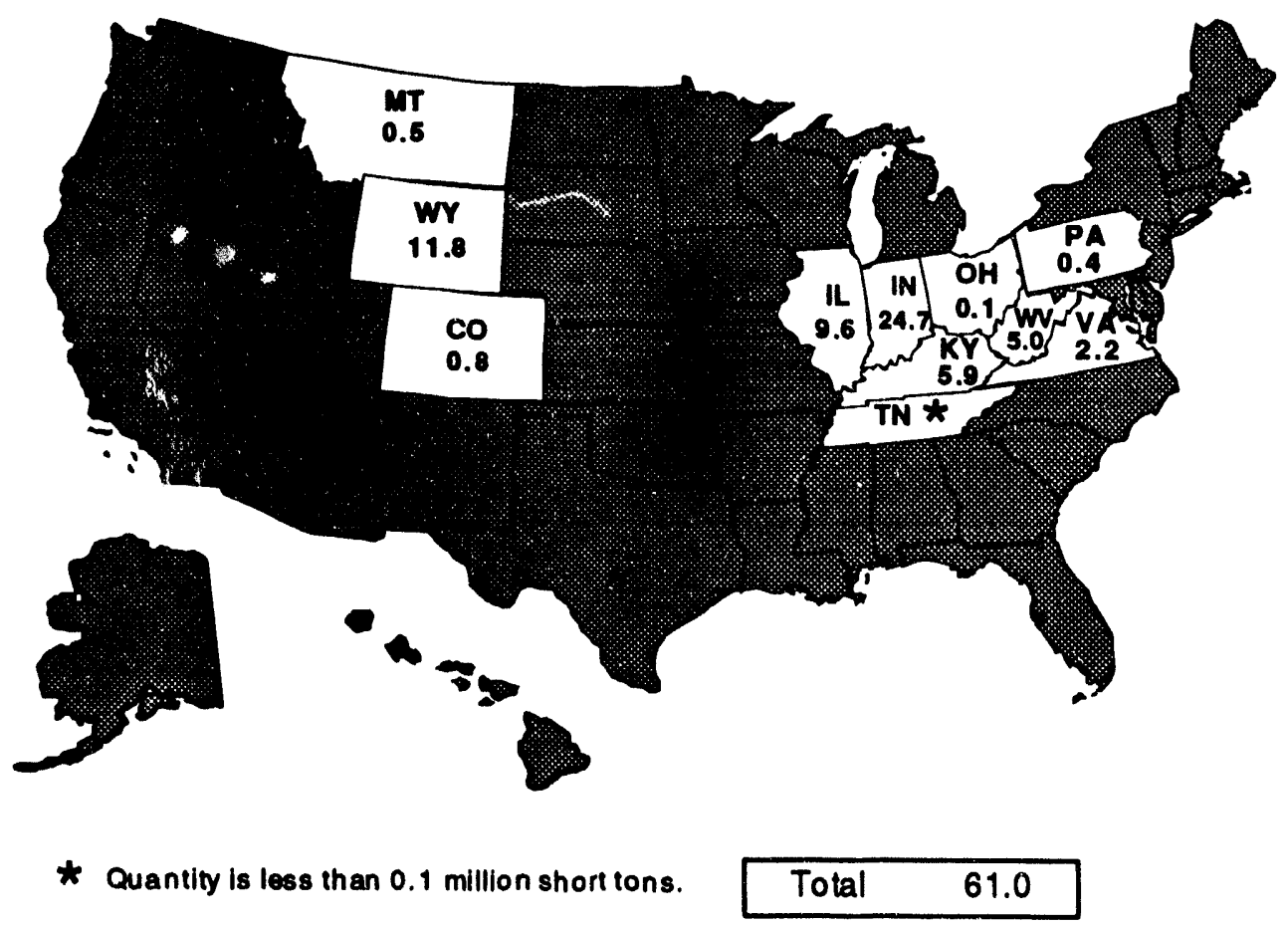

Note: Total may not equal sum of components because of independent rounding.

Source: Energy Information Administration, Form EIA-6, "Coal Distribution Report." 


\section{State Coal Profile: lowa}

Bituminous coal is the only fossil fuel produced in Iowa. The coal output is small. The 289,000 short tons produced in 1992 ranked it 25th among the 27 coalproducing States. The value of the coal production was less than 2 percent of the estimated total value of all mineral commodities produced in lowa.

Iowa's coal-bearing areas, located in the northern part of the Western Interior coal region, underlie about onethird of the State. The coalbeds are often discontinuous and limited in extent. The coal is bituminous in rank. Although Iowa coal has a relatively high heat content, averaging around $\mathbf{2 0}$ million Btu per short ton, its use is limited because of its high sulfur content, which averages more than 3 percent by weight. Before use, it is blended with low-sulfur coal from other States to meet clean air regulations.

Coal production in Iowa dates back to 1840 , when a mine at Farmington, Van Buren County, supplied local markets and steamships that plied the Des Moines River. Following the Civil War, extensive railroad construction in lowa provided access to new markets for lowa coal producers and also increased the demand for coal as a railroad fuel. Iowa coal became an important source of coal for locomotives heading westward across the Great Plains. Before 1900, coal mining was a major industry in the State, and Iowa was the leading coal producing State west of the Mississippi River. Iowa's cual output peaked in 1917 at 9 million short tons.
Afterwards, production dwindled as the railroads converted to diesel locomotives and other consumers switched to petroleum and natural gas or to better quality coal from other States, first from neighboring Illinois and, more recently, from Wyoming. Iowa's annual coal production dropped below 1 million short tons in the late $1960^{\circ} \mathrm{s}$, and has been less than 500,000 short tons since 1985.

Iowa's coal output in 1992 was entirely from Marion County, in the southern part of the State. All production was from the Ford coalbed (also known as the Lower Ford and the Cherokee), which is about 4 feet thick. Production was all from surface mines; the last underground mine in lowa closed in 1990. The American No. 1 surface mine of American Coals Corporation was the leading producer in 1992.

Virtually all of the coal produced in Iowa in 1992 was used within the State for electricity generation. However, considerably more coal was consumed in the State than was produced. Most of the 18 million short tons consumed in 1992 was from Wyoming. By far, electric utilities were the leading coal consumers in lowa. The major coal-burning generating facility is the 950megawatt George Neal North plant of Iowa Public Service Company, in Woodbury County. Coal was also used in lowa as a source of heat in corn milling to produce syrup, starch, and similar products. 


\section{lowa}

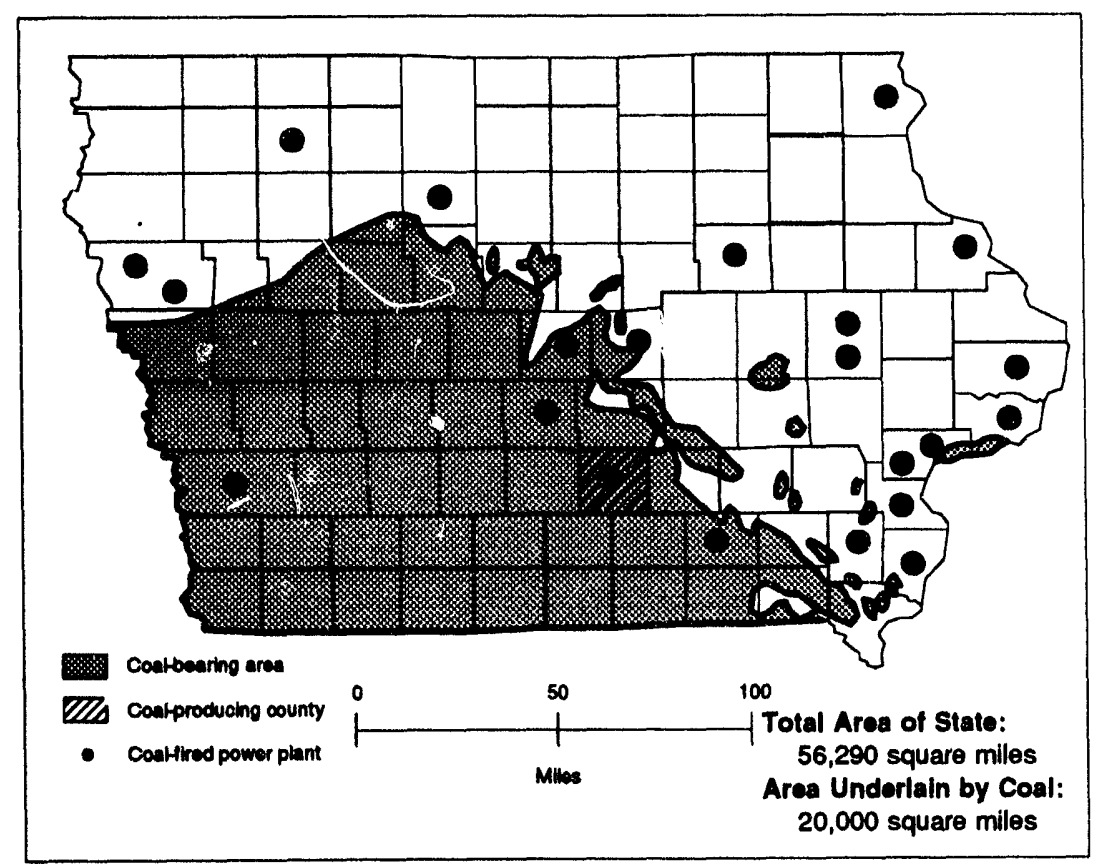

Coal Production, 1890-1992

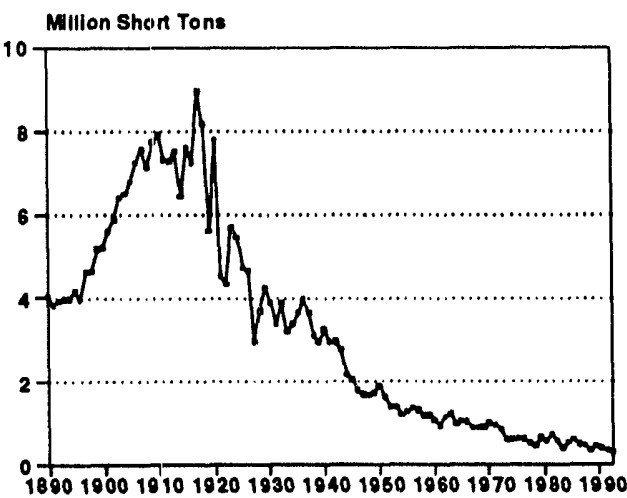

\section{Coal Reserves (Million Short Tons)}

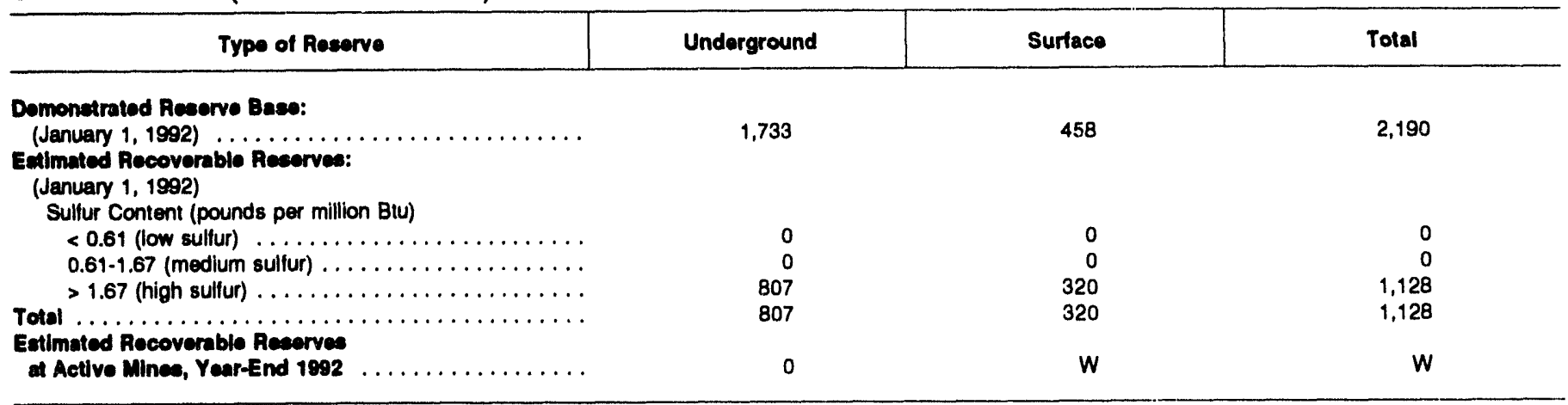

\section{Production}

\begin{tabular}{|c|c|c|c|c|c|}
\hline Sallent Date by Mine Type & 1980 & 1985 & 1980 & 1991 & 1992 \\
\hline \multicolumn{6}{|l|}{ Undercround } \\
\hline Quantity (thousand short tons) $\ldots \ldots \ldots \ldots \ldots \ldots \ldots$ & 166 & 172 & $<1$ & 0 & 0 \\
\hline 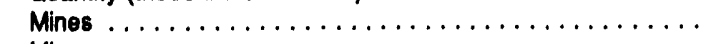 & $i$ & 1 & 1 & 0 & 0 \\
\hline 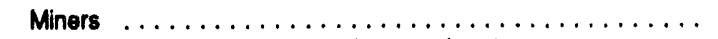 & 31 & 42 & NA & 0 & 0 \\
\hline Productivity (short tons per miner per hour) $\ldots \ldots \ldots \ldots$ & 2.07 & 1.77 & NA & $\cdots$ & -- \\
\hline Average Mine Price (dollars per short ton) $\ldots \ldots \ldots \ldots \ldots$ & W & W & NA & $\cdots$ & $\cdots$ \\
\hline \multicolumn{6}{|l|}{ Surtace } \\
\hline Quantity (thousand short tons) $\ldots \ldots \ldots \ldots \ldots \ldots \ldots$ & 393 & 419 & 381 & 344 & 289 \\
\hline 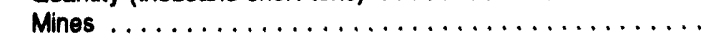 & 5 & 4 & 2 & 3 & 2 \\
\hline 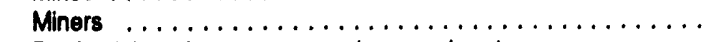 & 112 & 100 & 135 & 97 & 101 \\
\hline Productivity (short tons per miner per hour) $\ldots \ldots \ldots \ldots \ldots$ & 1.59 & 1.78 & 1.45 & 1.29 & 1.14 \\
\hline Average Mine Price (dollars per short ton) . . . . . . . . . . . & W & W & $W$ & $W$ & W \\
\hline \multicolumn{6}{|l|}{ Total } \\
\hline Quantity (thousand short tons) & 559 & 591 & 384 & 344 & 289 \\
\hline 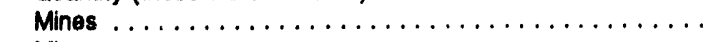 & 6 & 5 & 3 & 3 & 2 \\
\hline 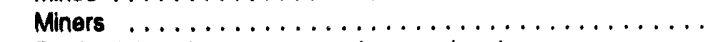 & 143 & 142 & 135 & 97 & 101 \\
\hline Productivity (shon tons per miner per hour) $\ldots \ldots \ldots \ldots$ & 1.70 & 1.78 & 1.45 & 1.29 & 1.14 \\
\hline Average Mine Price (dollars per short ton) $\ldots \ldots \ldots \ldots$ & 21.33 & 26.13 & W & W & W \\
\hline
\end{tabular}


lowa

Number of Mines by Production Range and Percent of Production, 1992

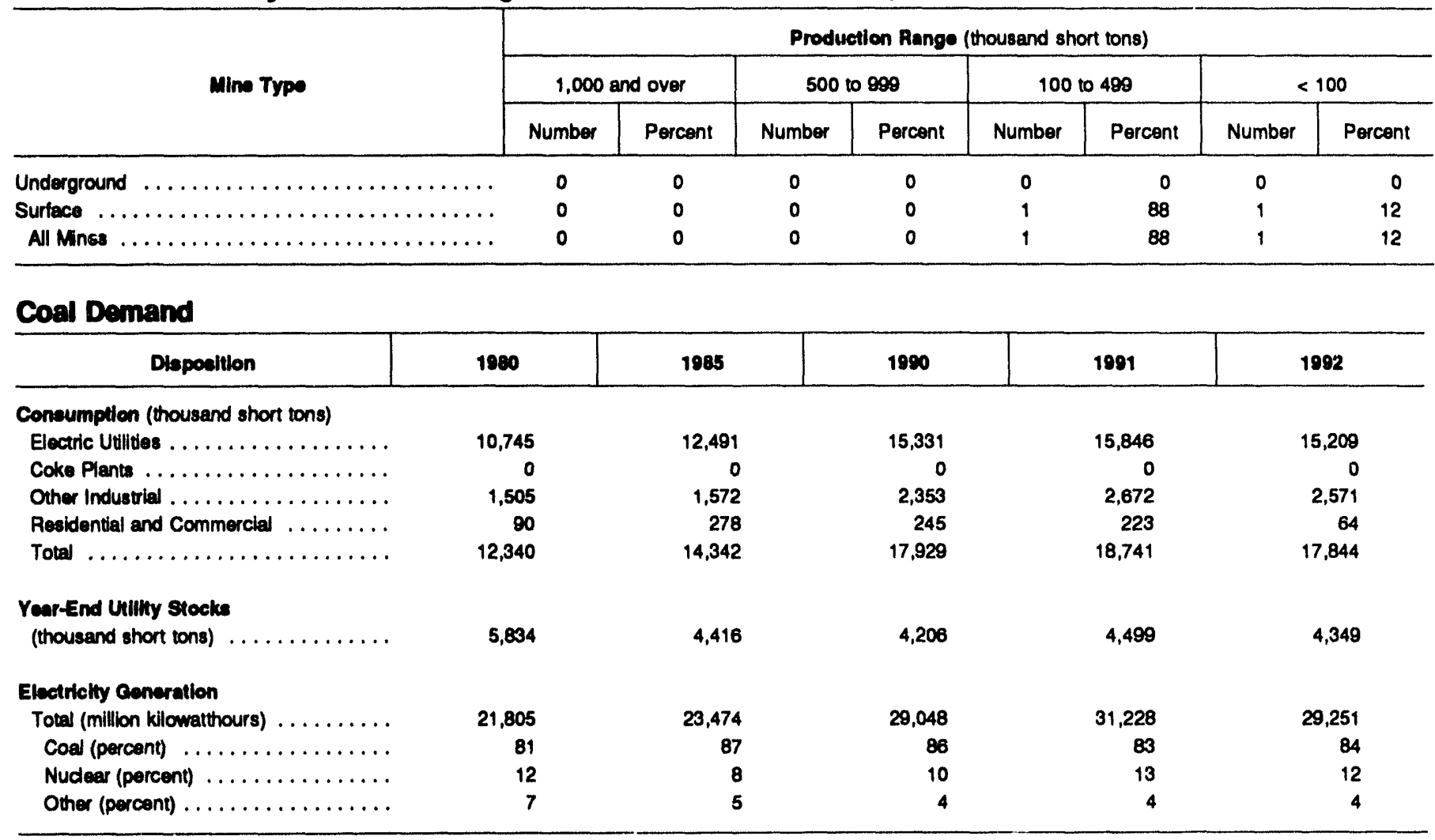

Utility Coal Data, 1992

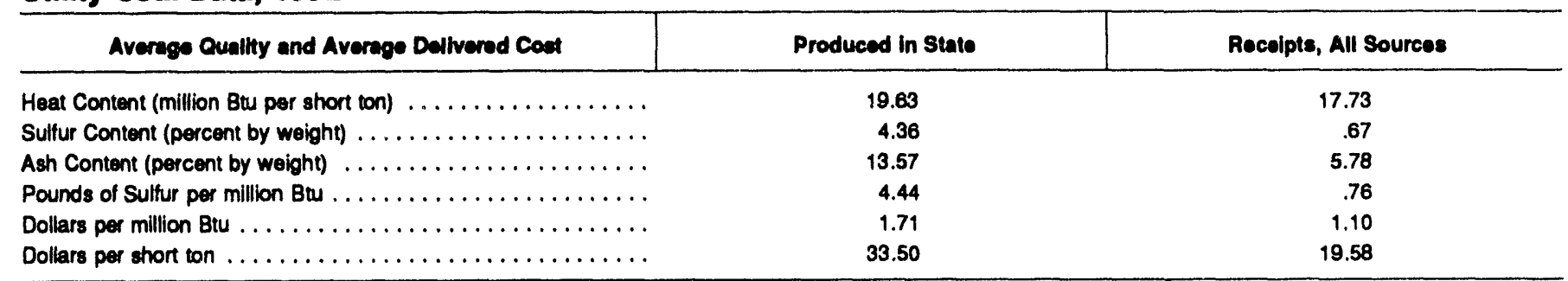

Eetimated Total State Energy Consumption, 1901: 937 trillion Btu (cosl, 346; natural ges, 235; potroloum, 309; nuclear electrlc power, 45; hydroelectric power, 9; other, <1; net interstato flow of electriclty and esecoclated loseces, -7).

$W=$ Witheid to avoid disclosure of individual company data.

NA $=$ Not available.

Notes: Totals may not equal sum of components because of independent rounding. Data coverage-Production: all mines. Number of mines: 1980, mines that produced 10,000 short tons or more; other years, all mines. Number of miners and productivity: mines that produced 10,000 or more short tons and preparation plants that had 5,000 or more employee hours. Average mine price: mines that produced 10,000 or more short tons. Average quality and average delivered coet of unlility coal: power plants with a generator nameplate capacity of 50 megawatts or more. Extent of coal-bearing areas and locations of coal-consuming plants shown on map are approximate; small coal deposits are not shown. Coal-producing counties shown on map exclude any county where all 1992 output was from mines producing less than 10,000 short tons.

Sources: Energy Information Administration-U.S. Coal Resenves: An Update by Heat and Sulfur Content, February 1993; Coal Production 1992 and prior issues; Coal Data: A Reference; Quanterly Coal Repon October-December 1992 and prior issues; Eloctric Power Annual 1991 and prior issues; Electric Power Monthly, March 1993; Cost and Quality of Fuels for Eloctric Power Plants 1992; Inventory of Power Plants in the United States 1992; State Energy Data Repont 1991: Consumption Estimates; Map of coal-bearing areas is based mainly on U.S. Geological Sunvey map, Coalfields of the United States, 1960. Data for historical graph 1890-1975, U.S. Department of the Interior, Geological Survey and Bureau of Mines (Minerals Yearbook and annual predecessor Mineral Resources of the United States); 1976 forward, Energy Information Administration, Coul Production 1992 and prior issues. 


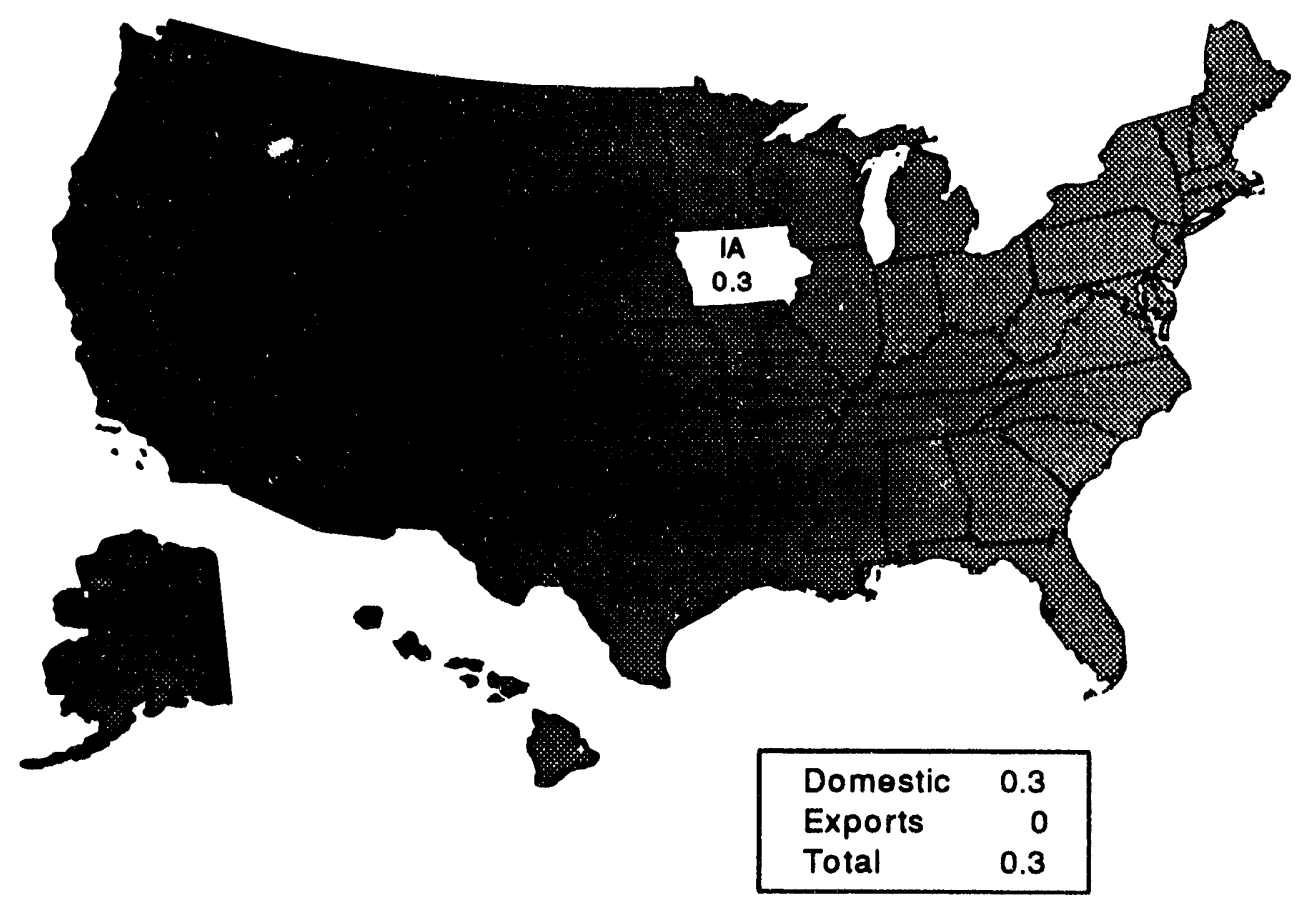

Traneportation modes, domestic markets (percent): truck, 100.

Note: Total may not equal sum of components because of independent rounding.

Source: Enengy Information Administration, Form EIA-6, "Coal Distribution Report."

\section{Origin of Coal Recolved in lowa, 1992}

(Milion Short Tons)

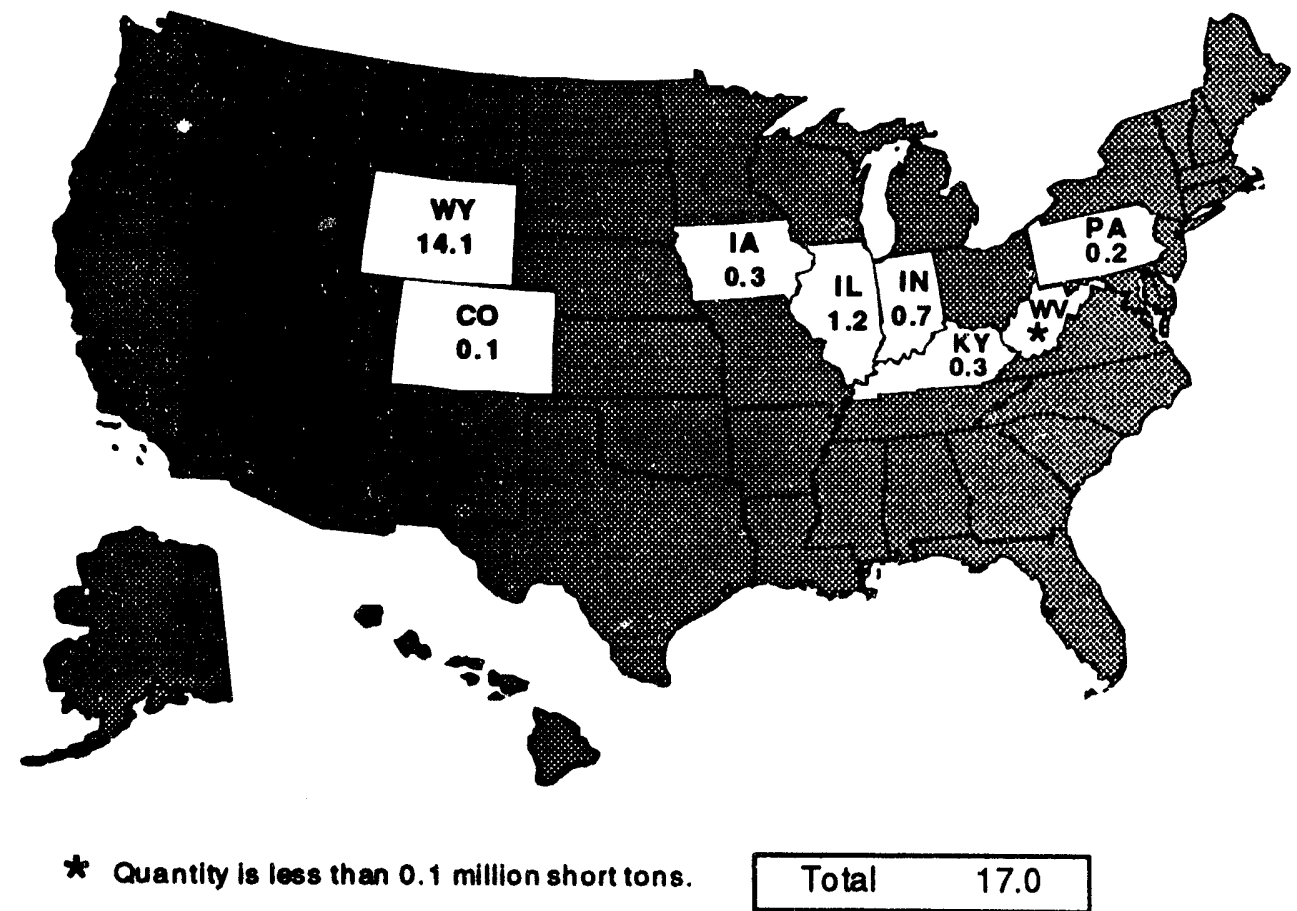

Note: Total may not equal sum of components because of independent rounding. Source: Energy Information Administration, Form EIA-6, "Coal Distribution Report." 


\section{State Coal Profile: Kansas}

Coal mining is a relatively small industry in Kansas. Production in 1992 was estimated to account for less than 1 percent of the total value of all mineral commodities produced in the State.

Coal deposits underlie about one-fourth of Kansas. All of the economically important coal is bituminous in rank and located in the eastern part of the State. The minable coalbeds are generally flat-lying and average about 2 feet in thickness. Production in 1992 was from the Mineral and Croweburg coalbeds. Kansas coal has a high heat content, averaging more than 21 million Btu per short ton, but the use of the cual is constrained by its high sulfur content, which averages about 4 percent by weight.

Historically, coal production had an important role in the development of Kansas. Although coal was mined in the mid-1850's, the first commercially important coal production began in 1865 when a mine near Fort Scott, in southeastern Kansas, began supplying coal for railroad locomotives. Later, other coal mines were opened to meet a growing demand for coal for the railroads and for domestic and industrial customers, including the large zinc and lead industry that developed in southeastern Kansas and adjoining States.

Coal production reached a peak of nearly 8 million short tons in 1918, when over 40 percent of the output was used by the railroads. Production in subsequent years trended downward, falling to 2 million short tons in the early 1930's. This was the result of a decline in economic activity due to the Depression, a drop in the railroad market as steam locomotives converted from coal to fuel oil, and competition in other markets from the oil and natural gas produced from large fields discovered in the State. Although coal production increased to 4 million short tons during World War II, it declined sharply afterwards, due largely to competition from petroleum. Annual production in recent years has fallen below 1 million short tons and was 363,000 short tons in 1992.

Underground mines produced large amounts of coal in Kansas in the early years, but all the coal produced since 1964 has been from surface mines. Surface mining began in Kansas in the 1870 's, when an early steam shovel was used to remove overburden from a coalbed near Pittsburg. As surface mining equipment improved, production from surface mines increased and in 1931 exceeded that from underground mines. In 1992, all production was from Crawford County. The leading producer was Clemens No. 2 strip mine of Clemens Coal Company. About half of the output was used in Kansas, and the rest was shipped to consumars in Missouri.

Contrasting with the small coal production in Kansas, annual coal consumption in Kansas has risen from less than 1 million short tons in the early 1970's and totaled 14 million short tons in 1992. Virtually all of the coal is used to generate electricity. This dramatic rise occurred because rising costs for oil and natural gas in the 1970's made coal the most economical fuel for power plants in the State. Of the total utility coal consumed in Kansas, most is low-sulfur subbituminous coal from Wyoming. Wyoming coal is used in the State's largest coal-fired generating facility, the 2,047-megawatt Jeffrey Energy Center of Kansas Power \& Light Company, in Pottawatomie County. A small amount of coal is also used by cement plants in the State. 


\section{Kansas}

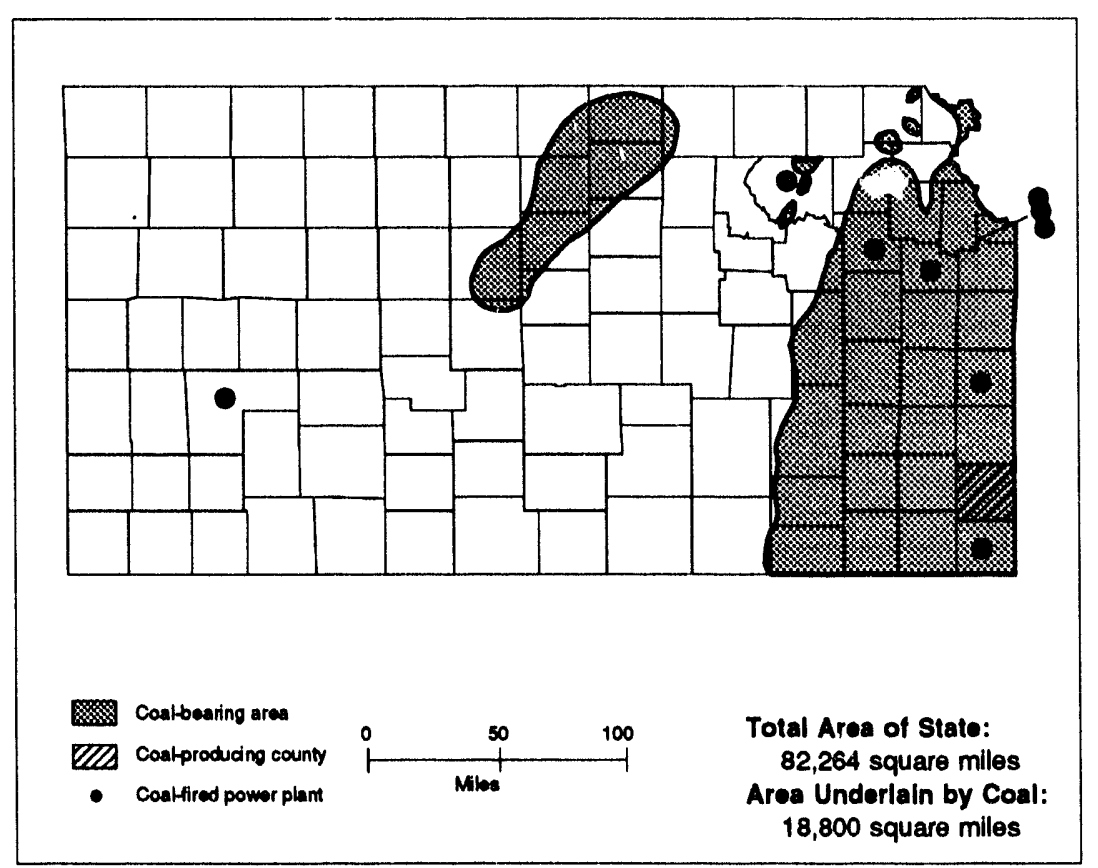

Coal Production, 1890-1992

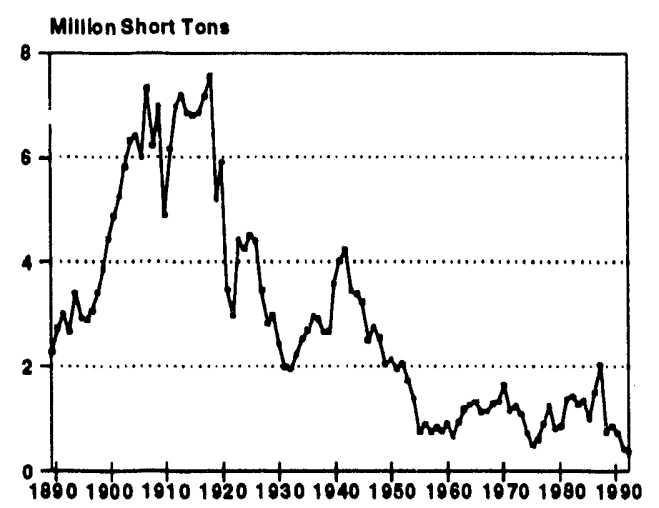

First Year of Documented Coal

Production . . . . . . . . . . . . 1869 (36,891 short tons) Peak Year of Coal

Production. $1918(7,562,000$ short tons)

Coal Reserves (Million Short Tons)

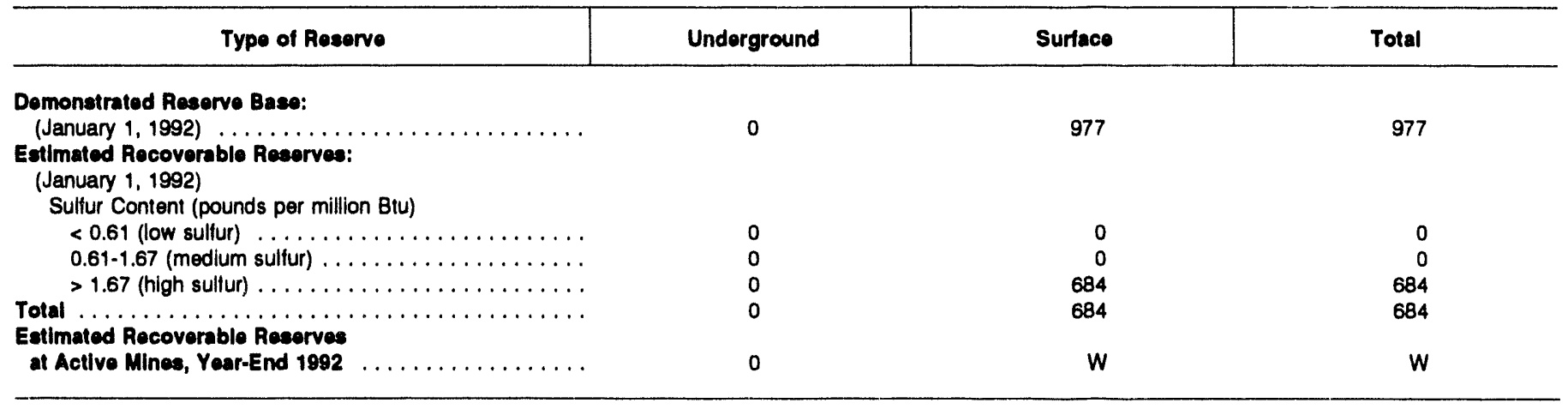

\section{Production}

\begin{tabular}{|c|c|c|c|c|c|}
\hline Sallent Data by Mine Type & 1980 & 1985 & 1990 & 1991 & 1992 \\
\hline \multicolumn{6}{|l|}{ Underground } \\
\hline Quantity (thousand short tons) $\ldots \ldots \ldots \ldots \ldots \ldots \ldots$ & 0 & 0 & 0 & 0 & 0 \\
\hline 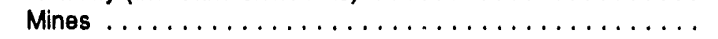 & 0 & 0 & 0 & 0 & 0 \\
\hline 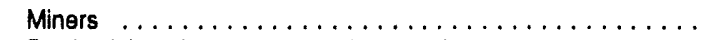 & 0 & 0 & 0 & 0 & 0 \\
\hline Productivity (short tons per miner per hour) $\ldots \ldots \ldots \ldots \ldots$ & -- & -. & -. & -. & .. \\
\hline Average Mine Price (dollars per short ton) $\ldots \ldots \ldots \ldots \ldots$ & -- & 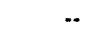 & $\cdots$ & $\cdots$ & $\cdots$ \\
\hline \multicolumn{6}{|l|}{ Surface } \\
\hline Quantity (thousand short tons) . & 842 & 994 & 721 & 416 & 363 \\
\hline 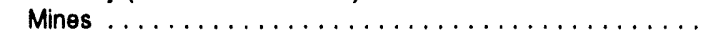 & 8 & 5 & 4 & 3 & 2 \\
\hline Miners $\ldots \ldots \ldots \ldots \ldots \ldots \ldots \ldots \ldots \ldots$ & 274 & 228 & 132 & 92 & 96 \\
\hline Productivity (short tons per miner per hour) $\ldots \ldots \ldots \ldots \ldots$ & 1.72 & 2.44 & 2.03 & 2.15 & 2.21 \\
\hline Average Mine Price (dollars per short ton) . . . . . . . . . . & 26.54 & 26.00 & $W$ & $W$ & $W$ \\
\hline \multicolumn{6}{|l|}{ Total } \\
\hline Quantity (thousand short tons) & 842 & 994 & 721 & 416 & 363 \\
\hline 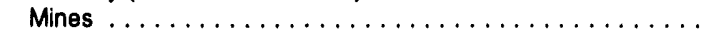 & 8 & 5 & 4 & 3 & 2 \\
\hline 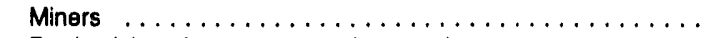 & 274 & 228 & 132 & 92 & 96 \\
\hline Productivity (short tons per miner per hour) . . . . . . . . . & 1.72 & 2.44 & 2.03 & 2.15 & 2.21 \\
\hline Average Mine Price (dollars per short ton) $\ldots \ldots \ldots \ldots \ldots$ & 26.54 & 26.00 & $W$ & $W$ & $W$ \\
\hline
\end{tabular}




\section{Kansas}

Number of Mines by Production Range and Percent of Production, 1992

\begin{tabular}{|c|c|c|c|c|c|c|c|c|}
\hline \multirow{3}{*}{ Mine Typo } & \multicolumn{8}{|c|}{ Production Range (thousand short tons) } \\
\hline & \multicolumn{2}{|c|}{1,000 and over } & \multicolumn{2}{|c|}{500 to 999} & \multicolumn{2}{|c|}{100 to 499} & \multicolumn{2}{|c|}{$<100$} \\
\hline & Number & Percent & Number & Percent & Number & Percent & Number & Percent \\
\hline Underground $\ldots \ldots$ & 0 & 0 & 0 & 0 & 0 & 0 & 0 & 0 \\
\hline Surtace $\ldots \ldots \ldots \ldots \ldots \ldots \ldots \ldots$ & 0 & 0 & 0 & 0 & 1 & 83 & 1 & 17 \\
\hline All Mines $\ldots \ldots \ldots \ldots \ldots \ldots \ldots \ldots \ldots \ldots$ & 0 & 0 & 0 & 0 & 1 & 83 & 1 & 17 \\
\hline
\end{tabular}

\section{Coal Demand}

\begin{tabular}{|c|c|c|c|c|c|}
\hline Disposition & 1980 & 1985 & 1890 & 1991 & 1992 \\
\hline \multicolumn{6}{|l|}{ Consumption (thousand short tons) } \\
\hline Electric Utillities $\ldots \ldots \ldots \ldots \ldots \ldots \ldots$ & 10,035 & 14,351 & 15,018 & 14,732 & 14,068 \\
\hline Coke Plants $\ldots \ldots \ldots \ldots \ldots \ldots \ldots$ & 0 & 0 & 0 & 0 & 0 \\
\hline Other Industrial $\ldots \ldots \ldots \ldots \ldots \ldots \ldots$ & 331 & 363 & 157 & 148 & 158 \\
\hline Residential and Commercial $\ldots . \ldots \ldots$ & 5 & 1 & 0 & 0 & 0 \\
\hline Total $\ldots \ldots \ldots \ldots \ldots \ldots \ldots \ldots \ldots$ & 10,371 & 14,715 & 15,175 & 14,881 & 14,227 \\
\hline \multicolumn{6}{|l|}{ Year-End Uillity Stocks } \\
\hline (thousand short tons) $\ldots \ldots \ldots \ldots \ldots$ & 4,667 & 3,513 & 3,729 & 3,310 & 2,747 \\
\hline \multicolumn{6}{|l|}{ Electricliy Conoration } \\
\hline Total (million kilowatthours) $\ldots \ldots \ldots \ldots$ & 25,134 & 27,512 & 33,869 & 32,315 & 31,764 \\
\hline Cod (percent) $\ldots \ldots \ldots \ldots \ldots \ldots$ & 64 & 80 & 70 & 73 & 70 \\
\hline Nuclear (percent) $\ldots \ldots \ldots \ldots \ldots \ldots$ & 0 & 14 & 23 & 18 & 27 \\
\hline Other (percent) $\ldots \ldots \ldots \ldots \ldots \ldots \ldots$ & 36 & 6 & 7 & 9 & 3 \\
\hline
\end{tabular}

\section{Utility Coal Data, 1992}

\begin{tabular}{|c|c|c|}
\hline Average Quality and Average Delivered Cost & Produced in Stato & Recelpte, All Sources \\
\hline Heat Content (million Btu per short ton) $\ldots \ldots \ldots \ldots \ldots \ldots \ldots$ & 24.39 & 17.80 \\
\hline Sulfur Content (percent by weight) $\ldots \ldots \ldots \ldots \ldots \ldots \ldots \ldots$ & 3.54 & .49 \\
\hline Ash Content (percent by weight) $\ldots \ldots \ldots \ldots \ldots \ldots \ldots \ldots$ & 11.70 & 5.74 \\
\hline Pounds of Sulfur per million Btu $\ldots \ldots \ldots \ldots \ldots \ldots \ldots \ldots$ & 2.90 & 0.55 \\
\hline Dollars per million Btu $\ldots \ldots \ldots \ldots \ldots \ldots \ldots \ldots \ldots$ & 1.29 & 1.18 \\
\hline Dollars per short ton $\ldots \ldots \ldots \ldots \ldots \ldots \ldots \ldots \ldots \ldots$ & 31.57 & 20.99 \\
\hline
\end{tabular}

Estimated Total State Energy Consumption, 1981: 1,039 trillion Btu (coal, 269; natural gas, 372; petroleum, 395; nuclear electric power, 63; hydroelectric power, <1; other, 0 ; not Interstate flow of electrlclty and aseociated losees, -59 ).

$W=$ Withheld to avoid disclosure of individual company data

Notes: Totals may not equal sum of components because of independent rounding. Data coverage-Production: all mines. Number of mines: 1980, mines that produced 10,000 short tons or more; other years, all mines. Number of miners and productivity: mines that produced 10,000 or more short tons and preparation plants that had 5,000 or more employee hours. Average mine prlce: mines that produced 10,000 or more shor tons. Average quality and average delivered coet of utility coal: power plants with a generator nameplate capacity of 50 megawatts or more. Extent of coal-bearing areas and locations of coalconsuming plants shown on map are approximate; small coal deposits are not shown. Coal-producing counties shown on map exclude any county where all 1992 output was from mines producing less than 10,000 short tons.

Sources: Energy Information Administration-U.S. Coal Reserves: An Update by Heat and Sulfur Content, February 1993; Coal Production 1992 and prior issues; Coal Data: A Reference; Quanterly Coal Report October-December 1992 and prior issues; Electric Power Annual 1991 and prior issues; Electric Power Monthly, March 1993; Cost and Quality of Fuels for Eloctric Power Plants 1992; Inventory of Power Plants in the United States 1992; State Energy Data Report 1991: Consumption Estimates; Map of coal-bearing areas is based mainly on U.S. Geological Survey map, Coalfields of the United States, 1960. Data for historical graph 1890-1975, U.S. Department of the Interior, Geological Survey and Bureau of Mines (Minerals Yeartook and annual predecessor Mineral Resources of the United States); 1976 forward, Energy Information Administration, Coal Production 1992 and prior issues. 
Deetination of Coal Produced in Kansas, 1992

(Milition Short Tons)

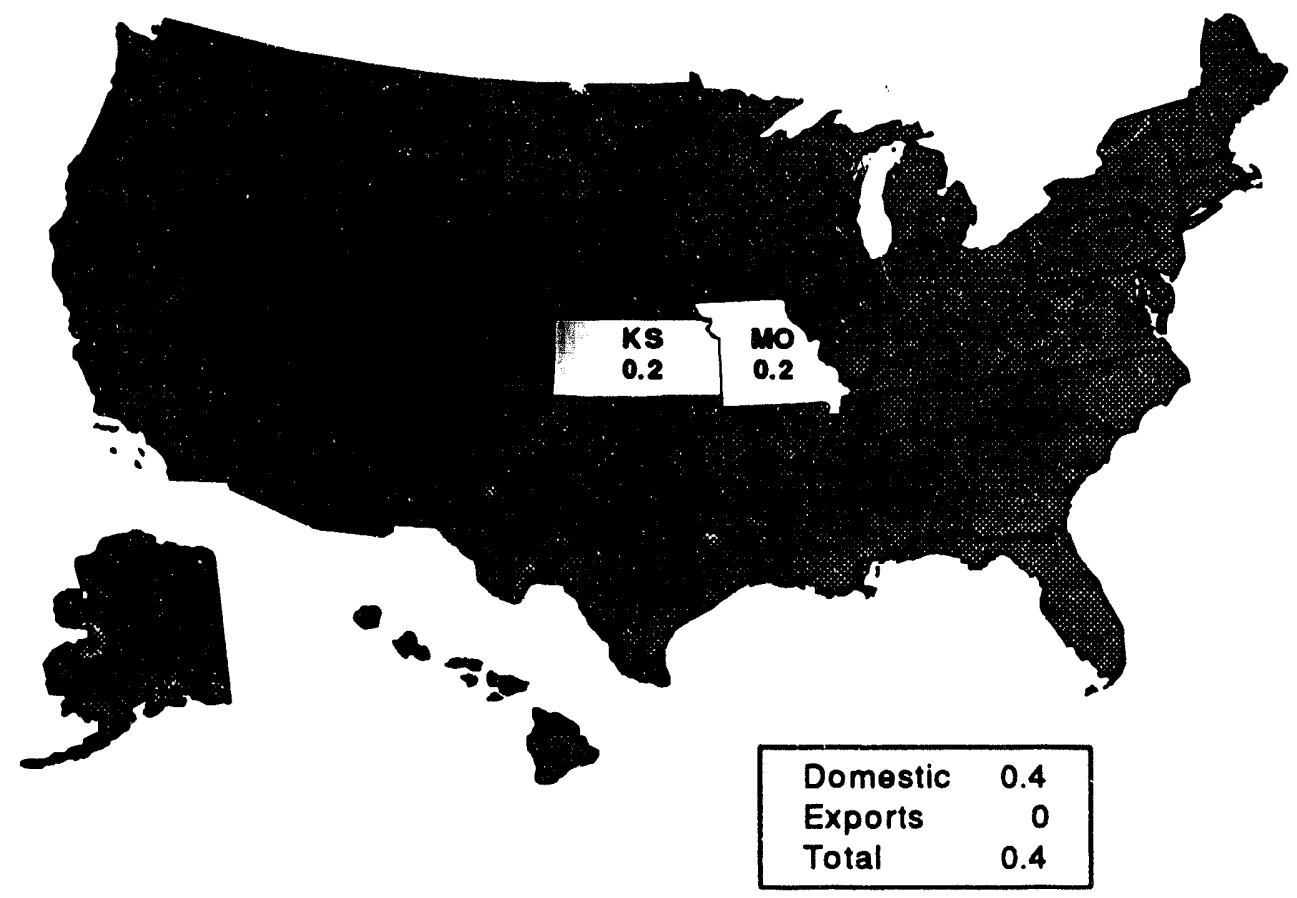

Transpcrtation modes, domestic markets (percent): rail, 6; truck, 92; unknown, 2.

Note: Total may not equal sum of components because of independent rounding.

Source: Energy Information Administration, Form ElA-6, "Coal Distribution Report."

Origin of Coal Recelved in Kansas, 1992

(Million Short Tons)

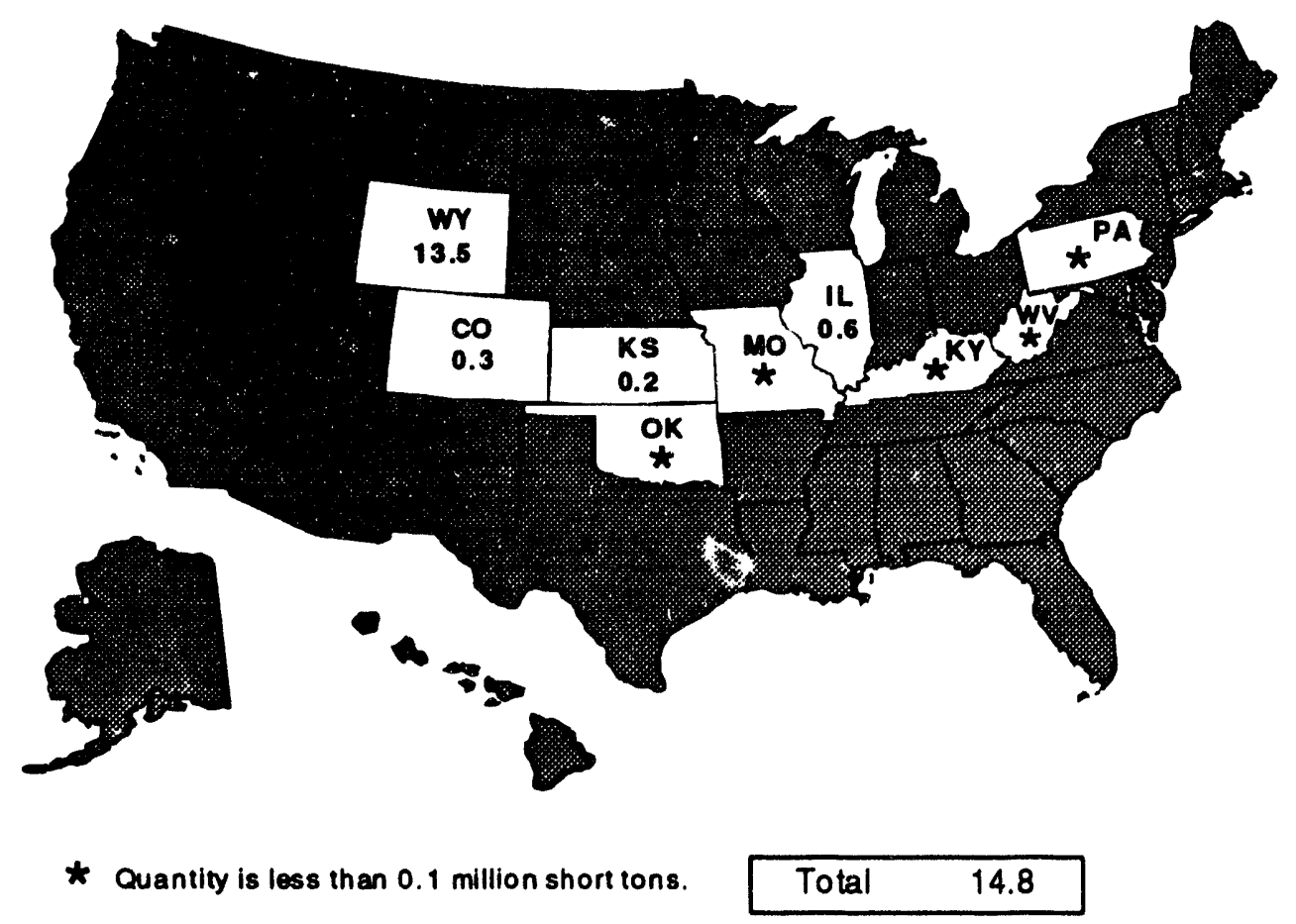

Note: Total may not equal sum of components because of independent rounding.

Source: Energy Information Administration, Form EIA-6, "Coal Distribution Report." 


\section{State Coal Profile: Kentucky}

Kentucky is one of the major coal-producing States, with an annual output averaging over 160 million short tons in recent years. It was the Nation's leading coal producer until 1988, holding that position for over a decade before losing it to Wyoming. In 1992, Kentucky was the third-leading coal-producing State, following Wyoming and West Virginia. Coal is by far the most important mineral commodity produced in Kentucky. The 1992 coal output was estimated to represent aborit 90 percent of the total value of all minerals producea, including oil and gas. Royalties from Federal coal leases totaled close to $\$ 1$ million, which was disbursed equally to the State and the Federal Government.

Kentucky's economic coal deposits consist of bituminous coal. The State's two coalfields, one in the East and the other in the West, are separated by a large geologic uplift, the Cincinnati arch. The eastern field, the larger of the two, is part of the Appalachian coal basin. The western field is a continuation of the Illinois coal basin, which also underlies parts of Illinois and Indiana. The coalfields are distinct in several ways due to different geologic conditions of coal formation in each area.

The eastern field contains more than $\mathbf{4 0}$ minable coalbeds, ranging from 2 to 4 feet in thickness. The coal generally has a heat content of about 26 million Btu per short ton and a sulfur content of 1 to 2 percent, by weight. Premium-grade metallurgical coal is present in some areas. By comparison, the western field has less than $\mathbf{2 0}$ minable coalbeds, which average 5 feet in thickness. The heat content of the coal is slightly lower than in the eastern field, but the sulfur content is higher, about 3 to 4 percent, which is an environmental shortcoming. The metallurgical coal found in western Kentucky is low grade. Because of these differences in coal quality, the eastern field has become Kentucky's chief source of coal production and the only area in the State where metallurgical coal is mined. In the eastern field, the major coalbeds in 1992 were the Hazard No. 4, Hazard, and Lower Elkhorn. In the western field, the No. 9 coalbed accounted for about half of production.

Coal was discovered in Kentucky in the mid-1700's, but production was small until the mid-1800's. The industry developed rapidly after 1910 as railroads were expanded into the coalfields. Early production was used in local iron furnaces, as a source of heat for salt production, and as fuel for locomotives and river steamers. Coal production exceeded 5 million short tons at the turn of the century, rose to about 69 million short tons in 1927, and then dropped to half that amount during the Depression years. Responding to the demands of World War II and the postwar Marshall Plan, Kentucky's coal output rose to 84 million short tons in 1947. Afterwards, production declined in the face of competition from petroleum, including the replacement of coal-fired locomotives with dieselelectric engines. The 1960's saw annual production recover and trend upward, due mainly to a growing market for utility coal. Production reached a record of 173 million short tons in 1990 and was 161 million short tons in 1992.

Nearly 60 percent of Kentucky's coal output is from underground mines, historically the principal source of production. Surface mining, which began in the 1920's, has increased almost steadily since World War II. During some years in the 1970's and early 1980's, surface mines produced more than half of the State's coal. Although Kentucky has the largest number of coal mines in the United States, more than half are small mines that annually produce less than 100,000 short tons each. As a result, the bulk of the State's coal production is from the relatively few larger mines. The State's largest mine in 1992, producing about 4 million short tons, was the No. 9 Wheatcroft underground mine of Costain Coal Inc., in Webster County. Pike County was by far Kentucky's leader in tonnage, with about one-fourth of the total. Federal leases accounted for less than 1 percent of the State's coal output in 1992. Kentucky's coal mining labor force in 1992 was the Nation's second largest after West Virginia.

Most of Kentucky's coal produced in 1992 was shipped out of the State. About 90 percent was marketed domestically, nearly all in the East, and the rest was exported. Coal consumption in Kentucky in 1992 totaled 35 million short tons, most of it from the State's coalfields. Electric utilities were the major coal consumers, using mostly Kentucky coal supplemented by small amounts from West Virginia and Indiana. The largest coal-burning generating facility is the 2,159megawatt Paradis: plant of the Tennessee Valley Authority, in Muhlenberg County. Small amounts of coal, mostly from Kentucky and West Virginia, were also used to produce metallurgical coke and as sources of heat, chiefly in the manufacture of plastics and similar products, inorganic chemicals, metals, and lime. 


\section{Kentucky}

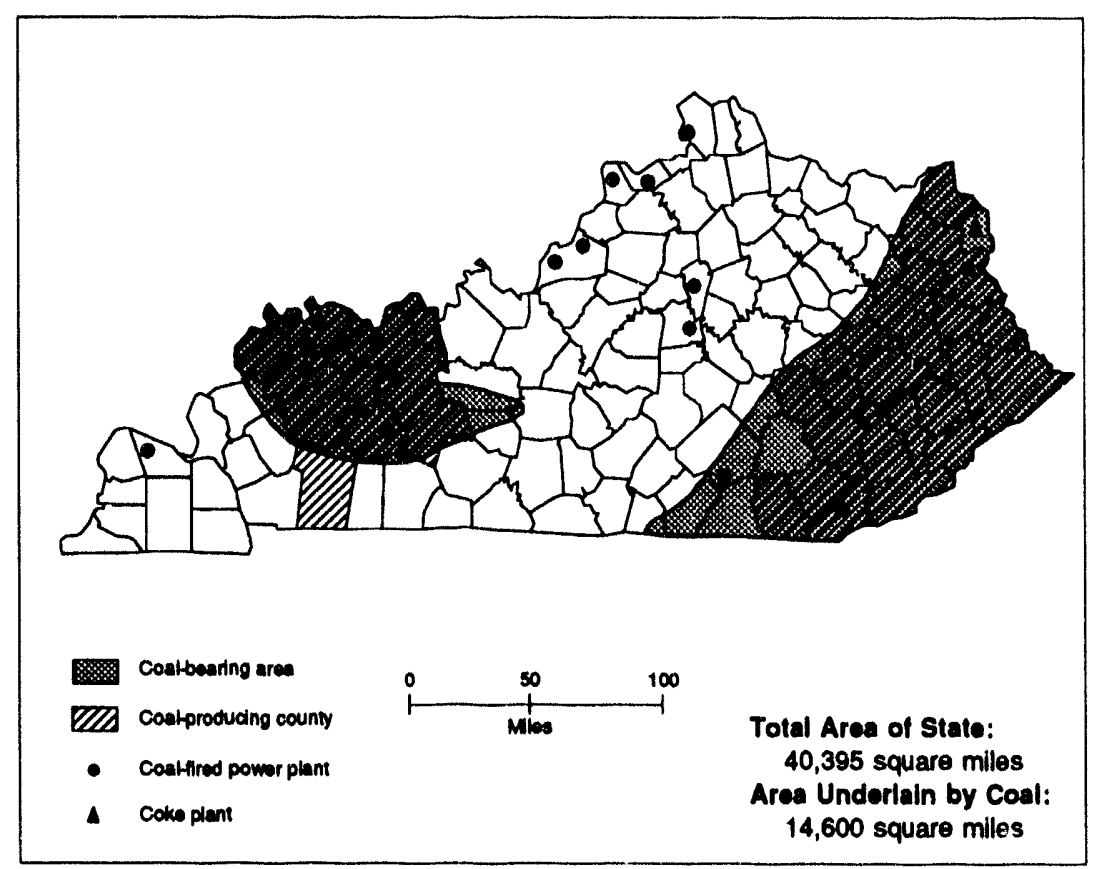

Coal Production, 1890-1992

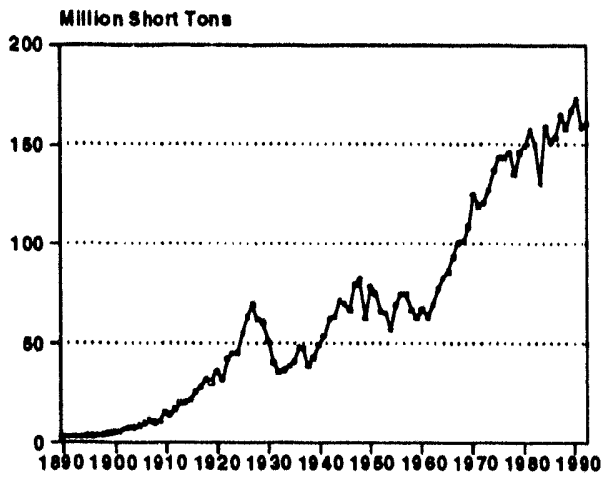

First Year of Documented Coal

Production . . . . . . . . . . . 1828 (328 short tons) Peak Year of Coal

Production . . . . . . . . 1990 (173,322,000 short tons)

\section{Coal Reserves (Million Short Tons)}

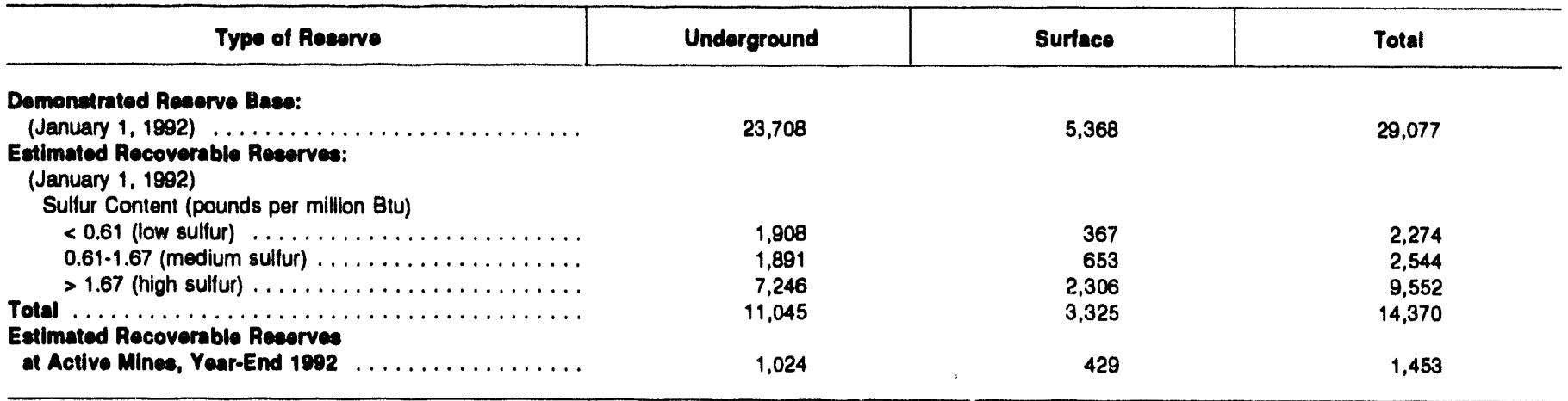

\section{Production}

\begin{tabular}{|c|c|c|c|c|c|}
\hline Sallent Data by Mino Typo & 1980 & 1985 & 1990 & 1991 & 1992 \\
\hline \multicolumn{6}{|l|}{ Undorground } \\
\hline Quantity (thousand short tons) $\ldots \ldots \ldots \ldots \ldots \ldots$ & 79,162 & 81,236 & 105,290 & 97,332 & 96,053 \\
\hline 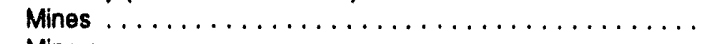 & 647 & 921 & 627 & 542 & 482 \\
\hline 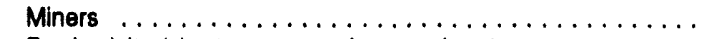 & 30,581 & 22,877 & 20,898 & 18,481 & 16,888 \\
\hline Productivity (short tons per miner per hour) $\ldots \ldots \ldots \ldots \ldots$ & 1.41 & 1.94 & 2.54 & 2.71 & 2.91 \\
\hline Average Mine Price (dollars per short ton) . . . . . . . . . . & 30.06 & 29.15 & 25.24 & 25.92 & 25.18 \\
\hline \multicolumn{6}{|l|}{ Surface } \\
\hline Quantity (thousand short tons) $\ldots \ldots \ldots \ldots \ldots \ldots \ldots$ & 70,982 & 71,036 & 68,032 & 61,647 & 65,016 \\
\hline Mines $\ldots \ldots \ldots \ldots \ldots \ldots \ldots \ldots \ldots \ldots \ldots$ & 503 & 937 & 360 & 296 & 270 \\
\hline Miners $\ldots \ldots \ldots \ldots \ldots \ldots \ldots \ldots \ldots \ldots \ldots$ & 15,814 & 13.937 & 9,600 & 8,161 & 7,736 \\
\hline Productivity (shor tons per miner per hour) $\ldots \ldots \ldots \ldots \ldots$ & 2.32 & 2.69 & 3.43 & 3.66 & 3.75 \\
\hline Average Mine Price (dollars per short ton) $\ldots \ldots \ldots \ldots \ldots$ & 25.05 & 27.19 & 25.11 & 24.70 & 23.50 \\
\hline \multicolumn{6}{|l|}{ Total } \\
\hline Quantity (thousand short tons) & 150,144 & 152,272 & 173,322 & 158,980 & 161,068 \\
\hline Mines $\ldots \ldots \ldots \ldots \ldots \ldots \ldots \ldots \ldots \ldots \ldots$ & 1,150 & 1,858 & 987 & 838 & 752 \\
\hline 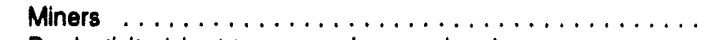 & 46,395 & 36,814 & 30,498 & 26,642 & 24,624 \\
\hline Productivity (short tons per miner per hour) $\ldots \ldots \ldots \ldots \ldots$ & 1.74 & 2.23 & 2.83 & 3.01 & 3.20 \\
\hline Average Mine frice (dollars per short ton) $\ldots \ldots \ldots \ldots \ldots$ & 27.62 & 28.24 & 25.19 & 25.45 & 24.50 \\
\hline
\end{tabular}




\section{Kentucky}

Number of Mines by Production Range and Percemt of Production, 1992

\begin{tabular}{|c|c|c|c|c|c|c|c|c|}
\hline \multirow[b]{2}{*}{ Mine Type } & \multicolumn{8}{|c|}{ Production Aange (thousand short tons) } \\
\hline & \multicolumn{2}{|c|}{1,000 and over } & \multicolumn{2}{|c|}{500 to 999} & \multicolumn{2}{|c|}{100 to 499} & \multicolumn{2}{|c|}{$<100$} \\
\hline Underground & 20 & 40 & 10 & 11 & 161 & 38 & 285 & 11 \\
\hline$\ldots \ldots \ldots \ldots \ldots$ & 14 & 37 & 24 & 25 & 85 & 32 & 147 & $\theta$ \\
\hline All Mines $\ldots \ldots \ldots \ldots \ldots \ldots \ldots \ldots \ldots \ldots$ & 34 & 39 & 40 & 17 & 246 & 36 & 432 & 8 \\
\hline
\end{tabular}

\section{Coal Demand}

\begin{tabular}{|c|c|c|c|c|c|}
\hline Dispoeltion & 1980 & 1985 & 1900 & 1991 & 1992 \\
\hline \multicolumn{6}{|l|}{ Coneumption (thousand short tons) } \\
\hline Electric Utilities $\ldots \ldots \ldots \ldots \ldots \ldots$ & 24,383 & 27,085 & 30,867 & 31,432 & 31,715 \\
\hline Coke Planto $\ldots \ldots \ldots \ldots \ldots \ldots \ldots$ & 905 & $w$ & $w$ & $w$ & w \\
\hline Other Industrial $\ldots \ldots \ldots \ldots \ldots \ldots \ldots$ & 1,969 & 2,510 & 2,253 & 2,044 & 1,848 \\
\hline Residential and Commercial $\ldots \ldots \ldots$ & 267 & $w$ & $w$ & $\mathbf{w}$ & w \\
\hline Total $\ldots . . . \ldots \ldots \ldots \ldots \ldots . . . . . .$. & 27.524 & 30,990 & 34,449 & 34,517 & 34,704 \\
\hline \multicolumn{6}{|l|}{ Year-End Uillty Stocks } \\
\hline (thousand short tons) .. & 9,948 & 6,864 & 7,612 & 5,881 & $\mathbf{5 , 4 1 5}$ \\
\hline \multicolumn{6}{|l|}{ Electriclity Coneration } \\
\hline Total (million kilowatthours) . ......... & 57,108 & 63,047 & 73,807 & 75,505 & 77,351 \\
\hline Coal (percent) $\ldots \ldots \ldots \ldots \ldots \ldots$ & 94 & 95 & 96 & 95 & 95 \\
\hline Nudiear (percent) $\ldots \ldots \ldots \ldots \ldots$ & 0 & 0 & 0 & 0 & 0 \\
\hline Other (percent) $\ldots \ldots \ldots \ldots \ldots \ldots \ldots$ & 6 & 5 & 4 & 5 & 5 \\
\hline
\end{tabular}

\section{Utility Coal Data, 1992}

Average Quality and Average Dellvered Cost

Produced in State

Recolpte, All Sources

Heat Content (million Btu per short ton) $\ldots \ldots \ldots \ldots \ldots \ldots$

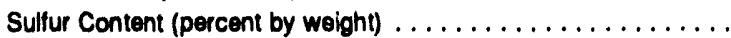

Ash Content (percent by weight) $\ldots \ldots \ldots \ldots \ldots \ldots \ldots \ldots$

Pounds of Sultur per million $B u \ldots \ldots \ldots \ldots \ldots \ldots \ldots$

Dollars per million $8 t u \ldots \ldots \ldots \ldots \ldots \ldots \ldots \ldots \ldots \ldots$

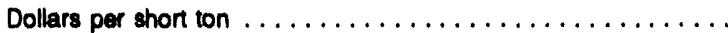

I.

23.24
2.44
11.60
2.10
1.16
27.01

Estimated Total Stato Energy Coneumption, 1991: 1,477 tillion Btu (coal,805; natural gas, 196; potroloum, 508; nuclear olectric power, 0; hydroolectric power, 38; other, 0; net interatate fow of electricity and aseoclated losese, -71).

\footnotetext{
$W=$ Withheld to avoid disctosure of individual company data.
}

Notes: Totale may not equal sum of components because of independent rounding. Data coverage-Production: all mines. Number of mines: 1980, mines that produced 10,000 short tons or more; other years, all mines. Number of miners and productivity: mines that produced 10,000 or more short tons and preparation plants that had 5,000 or more employee hours. Avorage mine price: mines that produced 10,000 or more short tons. Average quality and average dellvered coet of utility coal: power plants with a generator nameplate capacity of 50 megawatts or more. Extent of coal-bearing areas and locations of coal-consuming plants shown on map are approximate; small coal deposits are not shown. Coal-producing counties shown on map exclude any county where all 1992 output was from mines producing less than 10,000 short tons.

Sources: Energy Information Administration-U.S. Coal Reserves: An Update by Heat and Sulfur Content, February 1993; Coal Production 1992 and prior issues; Coel Data: A Reference; Quarterly Coal Report October-December 1992 and prior issues; Eloctric Power Annual 1991 and prior issues; Electric Power Monthly, March 1993; Cost and Quality of Fuels for Electric Power Plants 1992; Inventory of Power Plants in the United States 1992; State Energy Data Repon 1991: Consumption Estimates; Map of coal-bearing areas is based mainiy on U.S. Geological Survey map, Coalfields of the United States, 1960. Data for historical graph 1890-1975, U.S. Deparment of the interior, Geological Survey and Bureau of Mines (Minerals Yearbook and annual predecessor Mineral Resources of the United States); 1976 forward, Energy Information Administration, Coal Production 1992 and prior issues. 


\section{Destination of Coal Produced in Kentucky, 1992 \\ (Million Short Tons)}

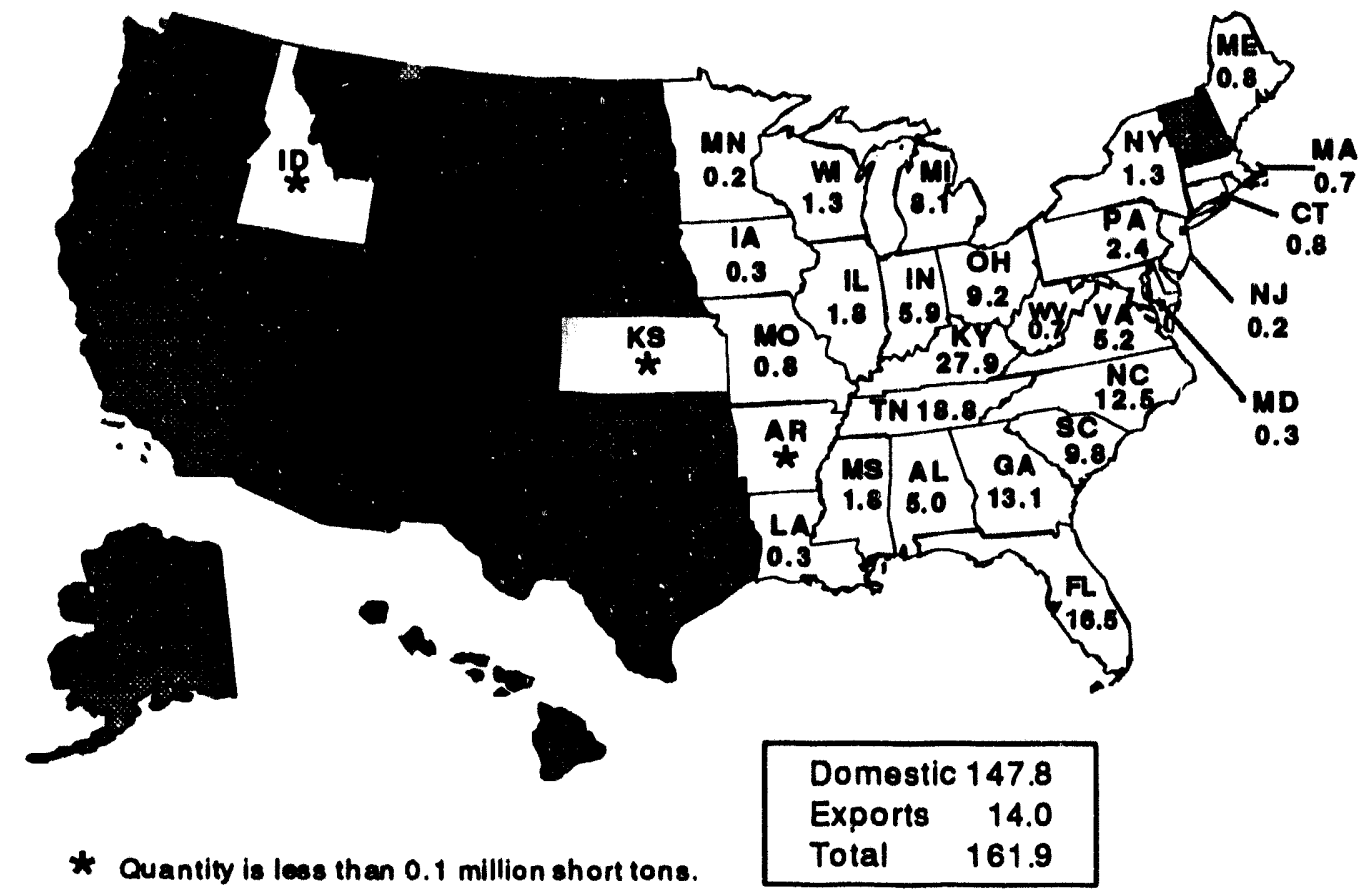

Transportation modes, domestic markets (percent): rall, 58; water, 31; truck, 8; tramway/conveyor, 1; unknown, 1.

Note: Total may not equal sum of components because of independent rounding.

Source: Energy Information Administration, Form EIA-6, "Coal Distribution Report."

\section{Origin of Coal Recelved in Kentucky, 1992}

(Million Short Tons)

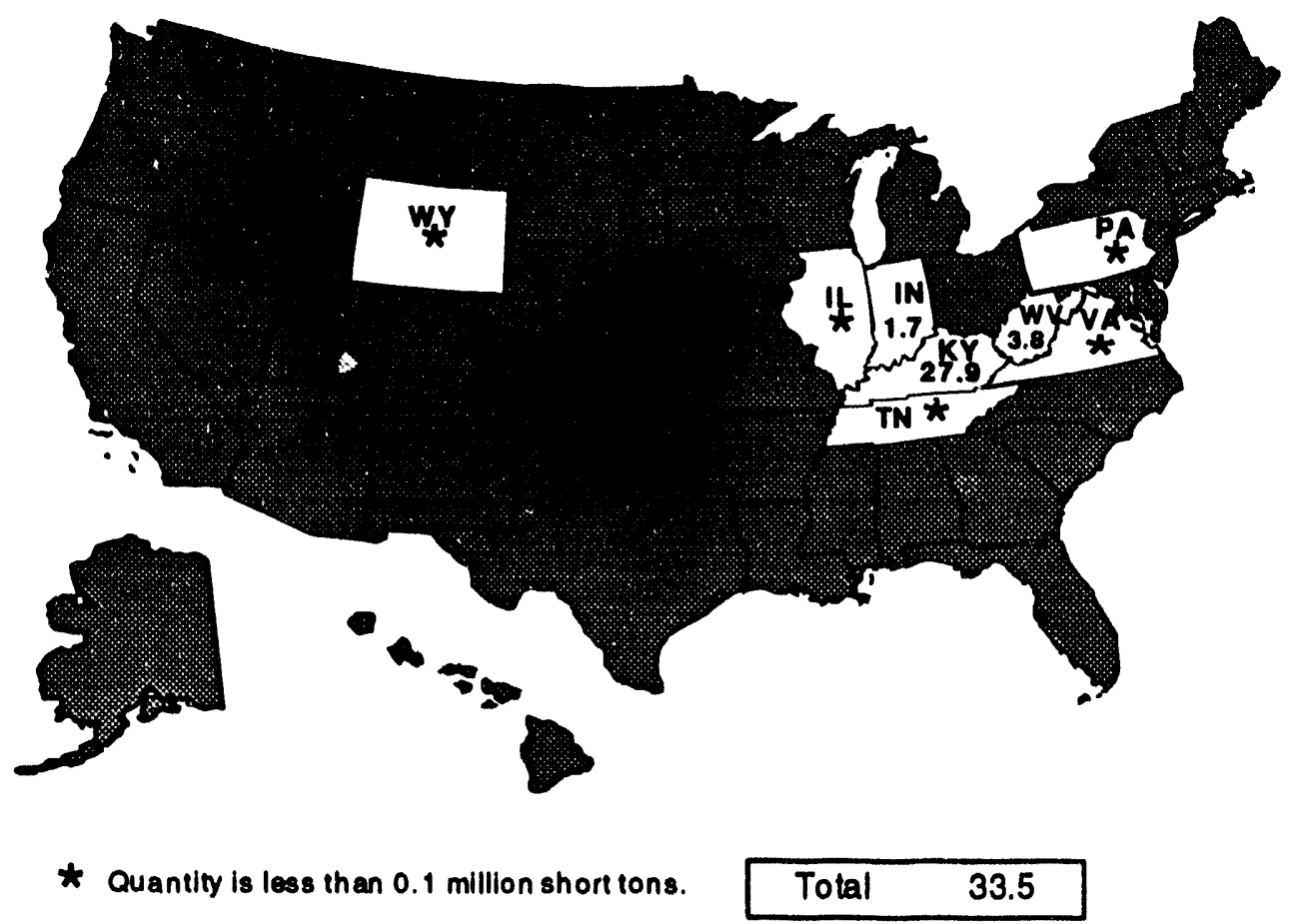

Note: Total may not equal sum of components because of independent rounding.

Source: Energy Information Administration, Form EIA-6, "Coal Distribution Report." 


\section{State Coal Profile: Louisiana}

Coal is a relatively new source of energy in Louisiana. Large amounts of coal from other States were first consumed in Louisiana in the early 1980's to generate electricity. Production and consumption of Louisiana's coal, all lignite, began in the mid-1980's. Although the annual output of lignite has risen to about 3 million short tons, its role in Louisiana's economy is greatly overshadowed by the large amounts of natural gas and crude oil produced in the State.

Lignite deposits of commercial importance occur in the northwestern part of Louisiana. Lignite was found in that area as early as 1812, nearly a century before petroleum was discovered in the State. In the early 1800 's, small amounts of lignite dug from outcrops were used locally as fuel for blacksmithing and domestic heating. Around the turn of the century, lignite was used to heat a school near Mansfield. It was also tested as a locomotive fuel, but found unsuitable. Attempts to mine lignite underground were short-lived, due not only to a lack of markets, but also to the difficulty of mining under strata that had to be supported with extensive timbering. Interest in lignite faded in the early 1900 's when the State's large oil and gas fields were developed.

Interest in Louisiana's lignite was renewed during World War II when the Nation assessed its mineral resources. The lignite could not compete as a fuel, but it had potential as raw material for making certain chemicals, dyes, fertilizers, and livestock feeds. A large amount of such products had been imported from Europe, particularly Germany. However, Louisiana's lignite was never used during the war.

In the 1950 's and 1960 's, lignite was recognized as a potential fuel for generating electricity in the State, and large reserves were delineated in the Dolet Hills area, near Mansfield, De Soto Parish. At the time, however, lignite was not cost-competitive. The economics changed in the late 1970's as pricing and legislation limited the use of natural gas as a power plant fuel. As a result, when the Central Louisiana Electric Company, Incorporated, and the Southwestern Electric Power Company evaluated their options to meet a growing demand for electricity, they jointly agreed that a minemouth power plant, fueled with lignite, would be the most economical choice. The site selected for both a surface mine and a power plant was Dolet Hills.
In 1985, the Dolet Hills mine, operated by Dolet Hills Mining Company, began supplying lignite to the power plant's stockpile by use of a 7.5-mile-long conveyor. The following year, the power plant began commercial operations with a generating capability of 650 megawatts. In late 1989, a second, smaller surface mine was opened in nearby Red River Parish to provide an additional source of lignite, delivered by truck to the power plant. In general, the lignite beds mined (part of the Wilcox Group) average 6 feet in thickness.

In 1992, Louisiana's lignite output climbed to a record of more than 3 million short tons. It accounted for about one-fourth of the 14 million short tons of coal consumed in the State. Wyoming was by far the principal source of coal consumed in Louisiana, nearly all used to generate electricity. The State's largest coalburning power plant is the 1,620-megawatt Big Cajun 2, operated by Cajun Electric Power Cooperative, Inc., in Pointe Coupee Parish. The plant is fueled with Wyoming subbituminous coal. The industrial use of coal in Louisiana is largely centered at a coal gasification plant at Plaquemine. The plant, placed in service in 1987, is one of three U.S. coal gasification plants currently in commercial use. It is operated by Destec Energy, Incorporated, to supply electricity and superheated steam to an adjacent chemical complex of the Dow Chemical Company. The plant has a generating capacity of 160 megawatts and uses more than 2,000 short tons of coal per day, all low-sulfur subbituminous coal from Wyoming. A small amount of coal from Kentucky is also used in paperboard manufacturing.

Large amounts of coal from other States are exported through the New Orleans Customs District, which includes the port areas of New Orleans and Baton Rouge on the lower Mississippi River. The coal is handled at terminals and also transloaded midstream from barges to ships. in 1992, about 13 million short tons of coal, mostly steam coal, were exported through the New Orleans Customs District. This represented about 13 percent of total U.S. coal exports and ranked New Orleans as the third-largest coal-exporting district, following Norfolk, Virginia, and Cleveland, Ohio. Small amounts of coal for power plants in other southern States have also been imported through New Orleans. 


\section{Loulsiana}

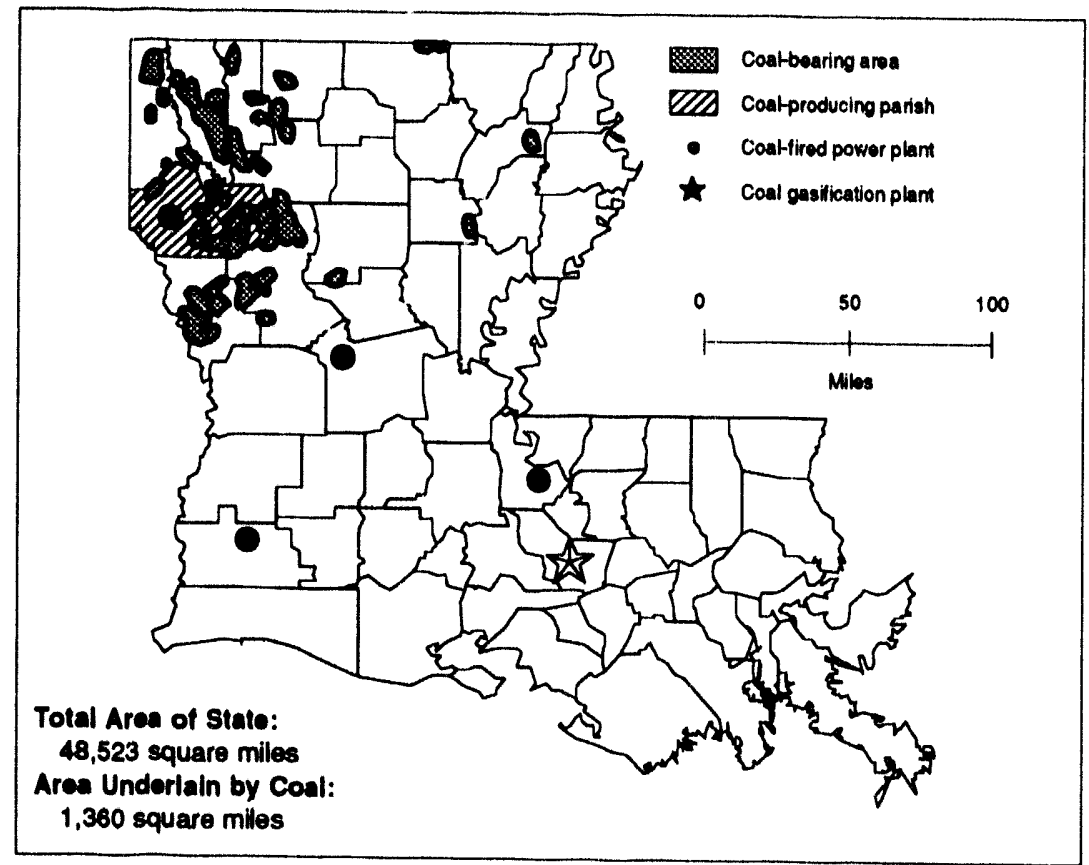

Coal Production, 1890-1992

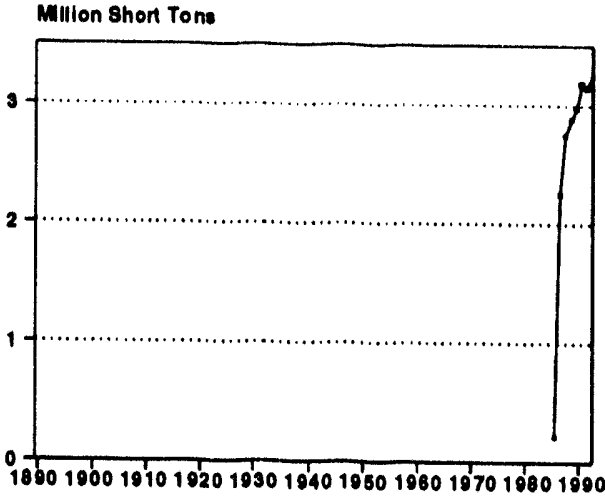

Firet Year of Documented Coal

Production . . . . . . . . . . . 1985 (207,000 short tons) Poak Yoar of Coal

Production.

$1992(3,240,000$ short tons $)$

Coal Reserves (million short tons)

\begin{tabular}{|c|c|c|c|}
\hline Type of Roserve & Underground & Surface & Total \\
\hline $\begin{array}{l}\text { Demonetrated Reserve Base: } \\
\text { (January 1, 1992) } \ldots \ldots \ldots \ldots \ldots \ldots \ldots \ldots \ldots \ldots \\
\text { Ettlmated Recoverable Reeserves: } \\
\text { (January 1, 1992) } \\
\text { Sultur Content (pounds per million Btu) }\end{array}$ & 0 & 484 & 484 \\
\hline 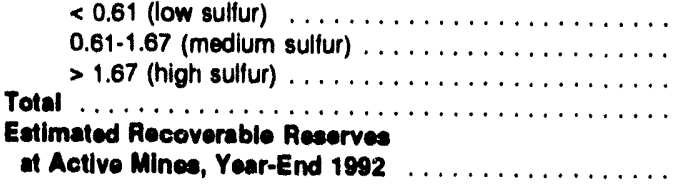 & $\begin{array}{l}0 \\
0 \\
0 \\
0 \\
0\end{array}$ & $\begin{array}{r}0 \\
359 \\
0 \\
359 \\
W\end{array}$ & $\begin{array}{r}0 \\
359 \\
0 \\
359 \\
W\end{array}$ \\
\hline
\end{tabular}

\section{Production}

\begin{tabular}{|c|c|c|c|c|c|}
\hline Sallent Data by Mine Type & 1980 & 1985 & 1990 & 1991 & 1992 \\
\hline \multicolumn{6}{|l|}{ Underground } \\
\hline Quantity (thousand short tons) $\ldots \ldots \ldots \ldots \ldots \ldots \ldots$ & 0 & 0 & 0 & 0 & 0 \\
\hline 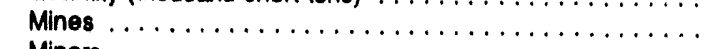 & 0 & 0 & 0 & 0 & 0 \\
\hline 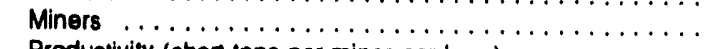 & 0 & 0 & 0 & 0 & 0 \\
\hline Productivity (short tons per miner per hour) $\ldots \ldots \ldots \ldots \ldots$ & .. & -. & -. & $m$ & .. \\
\hline Average Mine Price (dollars per short ton) $\ldots \ldots \ldots \ldots \ldots \ldots$ & 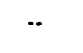 & .. & -- & $\cdots$ & $\cdots$ \\
\hline \multicolumn{6}{|l|}{ Surface } \\
\hline Quantity (thousand short tons) $\ldots \ldots \ldots \ldots \ldots \ldots \ldots$ & 0 & 207 & 3,186 & 3,151 & 3,240 \\
\hline 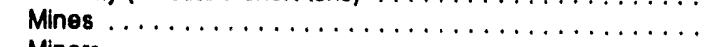 & 0 & 1 & 2 & 2 & 2 \\
\hline 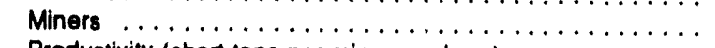 & 0 & 72 & 103 & 103 & 77 \\
\hline Productivity (short tons per miner per hour) $\ldots \ldots \ldots \ldots \ldots$ & .. & 2.34 & 13.16 & 12.56 & 12.43 \\
\hline Average Mine Price (dollars per short ton) $\ldots \ldots \ldots \ldots \ldots$ & $\cdots$ & $W$ & W & W & W \\
\hline \multicolumn{6}{|l|}{ Total } \\
\hline Quantity (thousand short lons) $\ldots \ldots \ldots \ldots \ldots \ldots$ & 0 & 207 & 3,186 & 3,151 & 3,240 \\
\hline 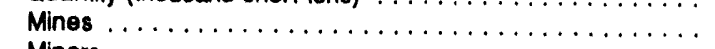 & 0 & 1 & 2 & 2 & 2 \\
\hline 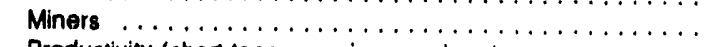 & 0 & 72 & 103 & 103 & 77 \\
\hline Productivity (short tons per miner per hour) $\ldots \ldots \ldots \ldots \ldots$ &.. & 2.34 & 13.16 & 12.56 & 12.43 \\
\hline Average Mine Price (dollars per short ton) $\ldots \ldots \ldots \ldots \ldots$ & .. & $w$ & $w$ & $W$ & W \\
\hline
\end{tabular}




\section{Loulslana}

Number of Mines by Production Range and Percemt of Production, 1992

\begin{tabular}{|c|c|c|c|c|c|c|c|c|}
\hline \multirow{3}{*}{ Mine Type } & \multicolumn{8}{|c|}{ Production Range (thousand short tons) } \\
\hline & \multicolumn{2}{|c|}{1,000 and over } & \multicolumn{2}{|c|}{500 to 999} & \multicolumn{2}{|c|}{100 to 499} & \multicolumn{2}{|c|}{$<100$} \\
\hline & Number & Percent & Number & Percent & Number & Percent & Number & Percent \\
\hline Underground $\ldots \ldots \ldots \ldots \ldots \ldots$ & 0 & 0 & 0 & 0 & 0 & 0 & 0 & 0 \\
\hline Surtace $\ldots \ldots \ldots \ldots \ldots \ldots \ldots \ldots$ & 1 & 83 & 1 & 17 & 0 & 0 & 0 & 0 \\
\hline All Mines $\ldots \ldots \ldots \ldots \ldots \ldots \ldots$ & 1 & 83 & 1 & 17 & 0 & 0 & 0 & 0 \\
\hline \multicolumn{9}{|l|}{ Coat Demand } \\
\hline Diaposition & 1980 & \multicolumn{2}{|c|}{1988} & 1990 & \multicolumn{2}{|r|}{1991} & \multicolumn{2}{|r|}{1992} \\
\hline \multicolumn{9}{|l|}{ Consumption (thousand short tons) } \\
\hline Electric Utilldes . . . . . . . . . . . . & 0 & \multicolumn{2}{|c|}{8,760} & \multicolumn{2}{|l|}{11,748} & 12,406 & \multicolumn{2}{|r|}{13,025} \\
\hline Coke Plants $\ldots \ldots \ldots \ldots \ldots \ldots \ldots$ & 0 & \multicolumn{2}{|c|}{0} & \multicolumn{2}{|l|}{0} & 0 & \multicolumn{2}{|r|}{0} \\
\hline Other Industrial $\ldots \ldots \ldots \ldots \ldots \ldots$ & 107 & \multicolumn{2}{|c|}{$w$} & \multicolumn{2}{|l|}{$w$} & $w$ & \multicolumn{2}{|r|}{$w$} \\
\hline Residential and Commercial ........ & 4 & \multicolumn{2}{|c|}{$w$} & \multicolumn{2}{|l|}{ w } & $\mathbf{w}$ & \multicolumn{2}{|r|}{ w } \\
\hline Total $\ldots \ldots \ldots \ldots \ldots \ldots \ldots \ldots$ & 111 & \multicolumn{2}{|c|}{9,217} & \multicolumn{2}{|l|}{12,547} & 12,965 & \multicolumn{2}{|r|}{13,622} \\
\hline \multicolumn{9}{|l|}{ Year-End Uillity Stocks } \\
\hline (thousand short tons) $\ldots \ldots \ldots \ldots$ & 0 & \multicolumn{2}{|c|}{1,978} & \multicolumn{2}{|l|}{2,458} & 2,235 & \multicolumn{2}{|r|}{1,701} \\
\hline \multicolumn{9}{|l|}{ Electricity Ceneration } \\
\hline Total (million kllowatthours) $\ldots \ldots \ldots$ & 45,744 & \multicolumn{2}{|c|}{44,261} & 58,168 & & 57,158 & & 55,188 \\
\hline Coal (percent) $\ldots \ldots \ldots \ldots \ldots$ & 0 & & 32 & 31 & & 33 & & 36 \\
\hline Nuclear (percent) $\ldots \ldots \ldots \ldots \ldots$ & 0 & & 6 & 24 & & 24 & & 19 \\
\hline Other (percent) $\ldots \ldots \ldots \ldots \ldots$ & 100 & & 32 & 45 & & 43 & & 45 \\
\hline
\end{tabular}

Utility Coal Data, 1992

\begin{tabular}{|c|c|c|}
\hline Averege Quallty and Average Delivered Cost & Produced In State & Recelpts, All Sources \\
\hline Heat Content (million Btu per short ton) $\ldots \ldots \ldots \ldots \ldots \ldots \ldots$ & 13.90 & 16.24 \\
\hline Sulfur Content (percent by woight) $\ldots \ldots \ldots \ldots \ldots \ldots \ldots$ & .62 & .50 \\
\hline Ash Content (percent by weight) $\ldots \ldots \ldots \ldots \ldots \ldots \ldots \ldots$ & 12.14 & 7.20 \\
\hline Pounds of Sultur per million Btu $\ldots \ldots \ldots \ldots \ldots \ldots \ldots$ & .89 & .62 \\
\hline Dollars per million Btu $\ldots \ldots \ldots \ldots \ldots \ldots \ldots \ldots \ldots$ & 1.38 & 1.54 \\
\hline Dollars per short ton $\ldots \ldots \ldots \ldots \ldots \ldots \ldots \ldots \ldots \ldots \ldots$ & 19.22 & 24.93 \\
\hline
\end{tabular}

Estimated Total State Energy Consumption, 1991: 3,469 trillion Btu (coal, 214; matural gas, 1,579; petroloum, 1445; nuclear electric power, 150; hydroelcetric power, 0; other, 0; not interstato flow of electrichy and associated loseses, 81).

$W=$ Witheld to avoid disclosure of individual company data.

Notes: Totals may not equal sum of components because of independent rounding. Data covorago-production: all mines. Number of mines: 1980, mines that produced 10,000 short tons or more; other years, all mines. Number of miners and productivity: mines that produced 10,000 or more short tons and preparation plants that had 5,000 or more employes hours. Average mine price: mines that produced 10,000 or more short tons. Average quality and average delivered coet of utility coal power plants with a generator nameplate capacity of 50 megawatts or more. Extent of coal-bearing areas and locations of coalconsuming plants shown on map are approximale; small coal deposits are not shown. Coal-producing counties shown on map exclude any county where all 1992 output was from mines producing less than 10,000 short tons.

Sources: Energy Information Administration-U.S. Coal Reserves: An Update by Heat and Sultur Content, Fobruary 1993; Coal Production 1992 and prior issues; Coal Data: A Reference; Quanenty Coal Repon October-December 1992 and prior issues; Electric Power Annual 1991 and prior issues; Electric Power Monthly. March 1993; Cost and Quality of Fuels for Eloctric Power Plants 1992; Inventory of Power Plants in the United States 1992; State Energy Data Repon 1991: Consumption Estimates; Map of coal-bearing areas is based mainly on U.S. Geological Survey map, Coalfields of the United Stales, 1960. Data for historical graph 1890-1975, U.S. Department of the Interior, Geological Survey and Bureau of Mines (Miinerals Yearbook and annual predecessor Mineral Resources of the United States); 1976 forward, Energy Information Administration, Coal Production 1992 and prior issues. 
Destinstion of Coal Produced in Loulsiana, 1992 (Million Short Tons)

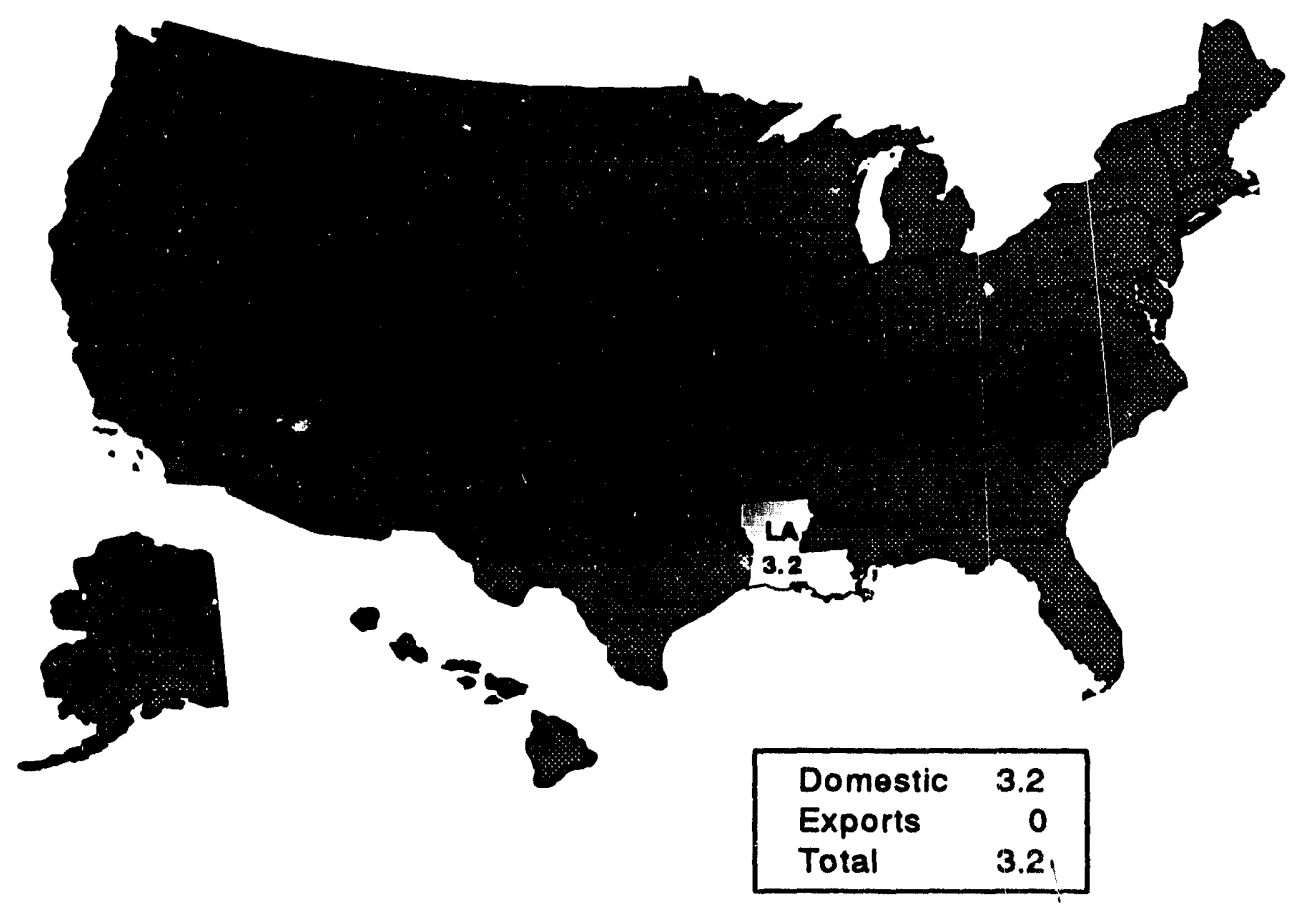

Transportation modes, domestic markets (percent): truck, 17; tramway/conveyor, 83.

Note: Total may not equal sum of components because of independent rounding. Source: Energy Information Administration, Form EIA-6, "Coal Distribution Report."

Origin of Coal Recelved in Loulsiana, 1992 (Million Short Tons)

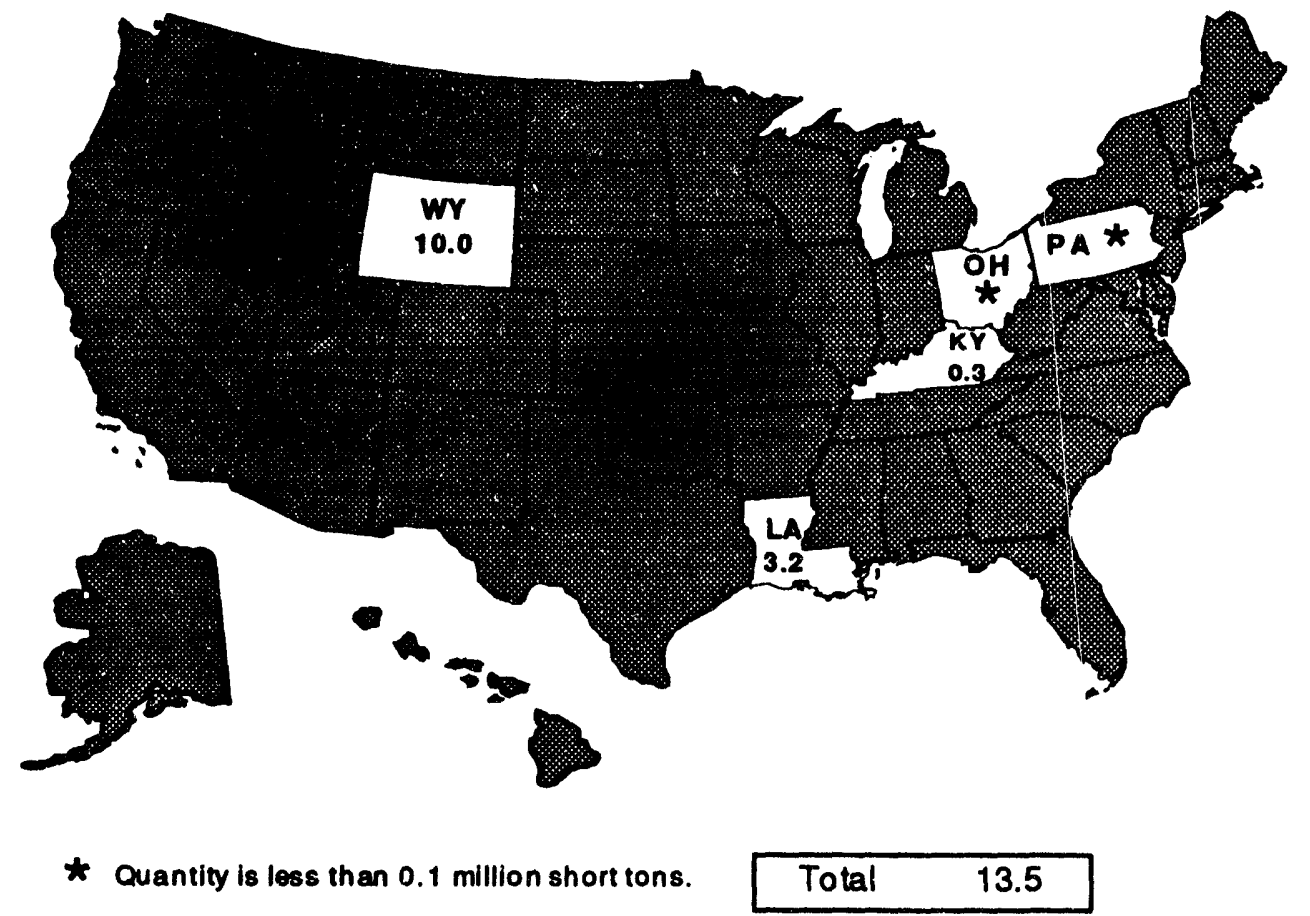

Note: Total may not equal sum of components because of independent rounding. Source: Energy Information Administration, Form EIA-6, "Coal Distribution Report." 


\section{State Coal Profile: Maryland}

Coal is the principal mineral fuel produced in the State, which also has a small output of natural gas from a deposit in the coal mining area. In 1992, the coal produced was estimated to represent about one-fifth of the total value of Maryland's mineral production.

Maryland's coal deposits are located in two western counties, Allegany and Garrett. The coal, all bituminous in rank, occurs in five elongated fields on the Allegheny Plateau, which composes the eastern edge of the Appalachian Coal Basin in the State. The coalbeds are moderately inclined on the flanks of the fields, but are generally flat within the fields.

Production is largely from two adjoining fields, Georges Creek and Potomac. Although about 13 coalbeds were mined in 1992, nearly three-fourths of the total output was from the Upper Freeport coalbed. The beds mined range from 2 to 10 feet in thickness. In recent years, both steam and metallurgical coal have been produced, the latter for the export market.

Maryland's coal production began in the 1780 's, when small amounts were mined for Fort Cumberland, a frontier ouipost. In 1830, the first coal shipments eastward were made by barge down the Potomac River, a route later abandoned because of the rapids in the river. The State's first coal mining company was incorporated in 1836, but coal production did not become important until the Baltimore and Ohio Railroad reached Cumberland in 1842 . In 1850 , the opening of the Chesapeake and Ohio Canal from Cumberland to Washington, D.C., provided another route for coal shipments. Over 21 million short tons of coal were transported on the canal before it closed in 1923.

Maryland's coal production rose above 1 million short tons in 1865, exceeded 4 million short tons by the turn of the century, and reached an all-time high of about 6 million short tons in 1907. A small amount of the coal produced in the early 1900 's was a premium smithing (blacksmith) coal that was specially processed and delivered in box cars to customers throughout the United States and in Canada. Coal production declined sharply after 1920, reflecting downturns in the economy, recurrent labor problems, and the extensive replacement of coal by petroleum. Production fell below 1 million short tons during the 1950's and early $1960^{\prime}$ 's before the trend turned upwards, due mostly to an increasing use of coal to generate electricity. Over 3 million short tons were produced in 1992.

Before World War II, underground mines accounted for most of Maryland's coal production. A rising demand during the war and a shortage of manpower at underground mines led to an increase in surface coal mining. Surface mines predominated until the early 1980 's, when underground production once again became the largest source of production, accounting for more than half of the total in recent years. The State's largest mine in 1992, producing more than 2 million short tons, was the Mettiki underground mine of Mapco Coal Inc., in Garrett County. Garrett County accounted for the bulk of the State's coal output in 1992.

Of the coal produced in 1992, more than 90 percent was for domestic markets and the rest was exported overseas. About 60 percent of domestic shipments were to electric power plants in West Virginia. Maryland's power plants received nearly all of the balance.

About 10 million short tons of coal were consumed in Maryland in 1992. Electric power plants were the major consumers, receiving about 10 percent of their requirements from mines in Maryland and most of the balance from West Virginia and Pennsylvania. Maryland's largest coal-generating facility is the 1,284-megawatt Brandon Shores plant of Baltimore Gas \& Electric Company, in Anne Arundel County. Small amounts of coal were used by other consumers, chiefly cement plants and a paper mill. Until early 1992, a coke plant was in operation at the Sparrows Point Steel Plant of Bethlehem Steel Corporation, near Baltimore.

The Baltimore Customs District is an important East Coast coal-exporting region, handling metallurgical and steam coal produced in northern Appalachia. In 1992, it accounted for 15 percent of the coal exported from the East Coast and 9 percent of total U.S. coal exports. Export coal is handled at the Bayside Transhipping Facility and the CONSOL Coal Terminal. 


\section{Maryland}

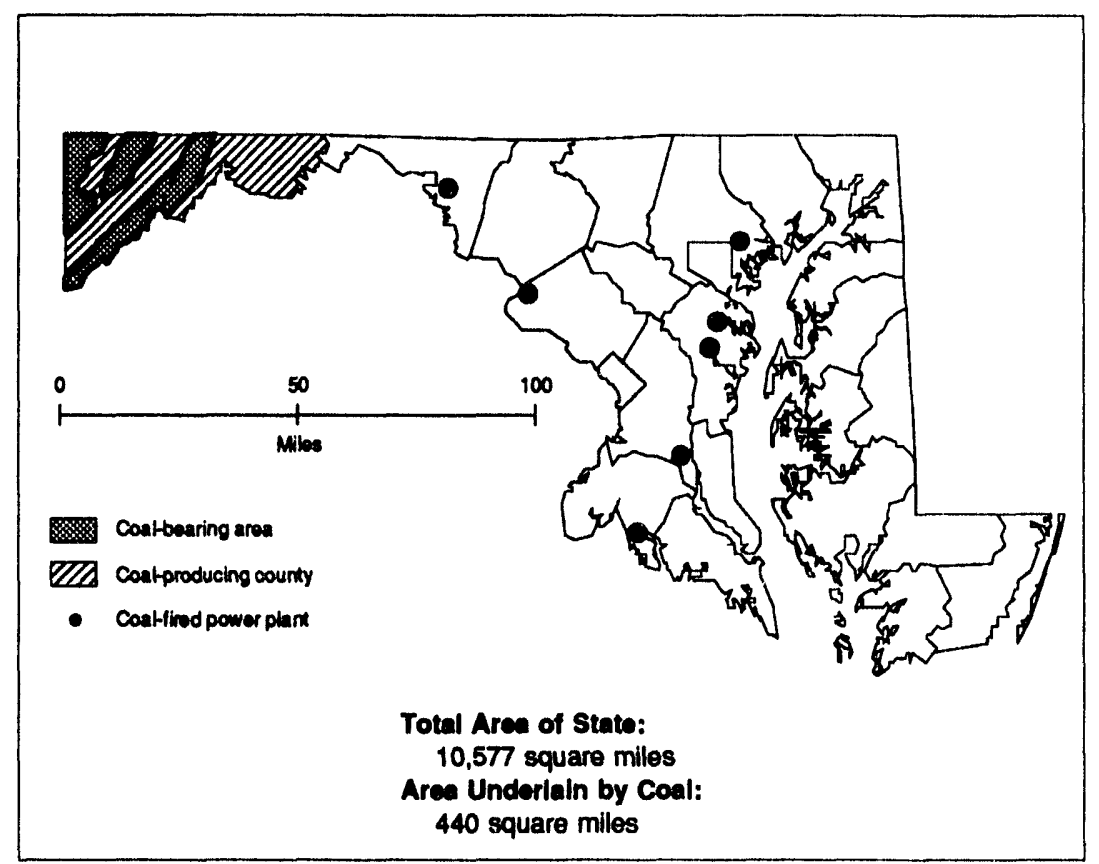

Cosl Production, 1890-1992

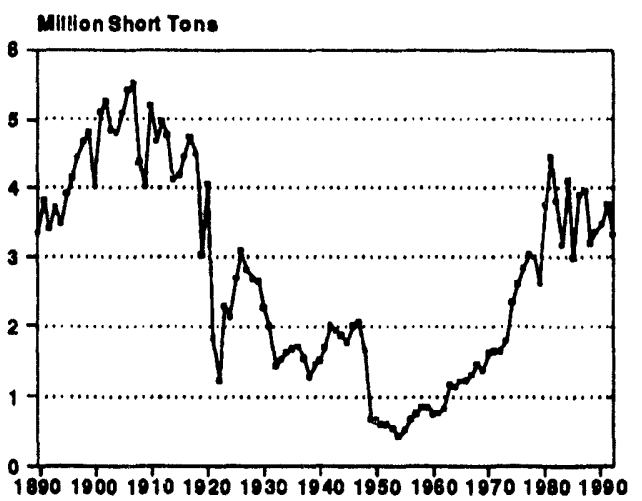

Firet Year of Documented Coal

Production

$1820(3,000$ short tons $)$

Peak Year of Coal

Production

$1907(5,533,000$ short tons)

Coal Reserves (Million Short Tons)

\begin{tabular}{|c|c|c|c|}
\hline Type of Reearve & Underground & Surtace & Total \\
\hline \multicolumn{4}{|l|}{ Demonetrated Reaerve Bace: } \\
\hline $\begin{array}{l}\text { (January } 1,1992) \ldots \ldots \ldots \ldots \ldots \ldots \\
\text { Estimated Recovernble Reserves: } \\
\text { (January } 1,1992 \text { ) } \\
\text { Sulfur Content (pounds per million Btu) }\end{array}$ & 664 & 86 & 750 \\
\hline $\begin{array}{l}<0.61 \text { (low sulfur) } \ldots \ldots \ldots \ldots \ldots \ldots \ldots \ldots \ldots \ldots \ldots \ldots \ldots \ldots \ldots \\
0.61-1.67 \text { (modium sulfur) } \ldots \ldots \ldots \ldots \ldots \ldots \ldots\end{array}$ & $\begin{array}{r}29 \\
158\end{array}$ & $\begin{array}{r}3 \\
22\end{array}$ & $\begin{array}{r}32 \\
180\end{array}$ \\
\hline$>1.67$ (high sulfur) $\ldots \ldots \ldots \ldots \ldots \ldots \ldots$ & 177 & 34 & 210 \\
\hline 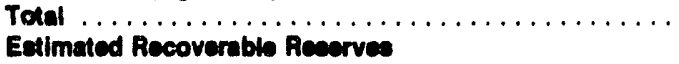 & 364 & 58 & 422 \\
\hline at Active Mines, Year-End $1902 \ldots \ldots \ldots \ldots \ldots$ & 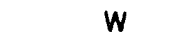 & $W$ & 59 \\
\hline
\end{tabular}

\section{Production}

\begin{tabular}{|c|c|c|c|c|c|}
\hline Salbm Data by Mine Typo & 1980 & 1986 & 1990 & 1981 & 1992 \\
\hline \multicolumn{6}{|l|}{ Underground } \\
\hline Quantity (thousand short tons) . & 1,494 & 1,785 & 1,985 & 2,631 & 2,270 \\
\hline Mines $\ldots \ldots \ldots \ldots \ldots \ldots \ldots \ldots \ldots \ldots \ldots$ & 4 & 6 & 1 & 2 & 3 \\
\hline Miners $\ldots \ldots \ldots \ldots \ldots \ldots \ldots \ldots \ldots \ldots \ldots$ & 561 & 375 & 288 & 309 & 228 \\
\hline Productivity (short tons per miner per hour) $\ldots \ldots \ldots \ldots \ldots$ & 1.48 & 2.48 & 3.17 & 3.73 & 3.50 \\
\hline Average Mine Price (dollars per short ton) $\ldots \ldots \ldots \ldots \ldots$ & 38.80 & W & W & $w$ & W \\
\hline \multicolumn{6}{|l|}{ Surfece } \\
\hline Quantity (thousand short tons) $\ldots \ldots \ldots \ldots \ldots \ldots$ & 2,266 & 1,200 & 1,502 & 1,142 & 1,071 \\
\hline Mines . . . . . . . . . . . . . . . . . . . & 28 & 39 & 26 & 24 & 21 \\
\hline Miners $\ldots \ldots \ldots \ldots \ldots \ldots \ldots \ldots \ldots \ldots \ldots$ & 526 & 303 & 301 & 215 & 210 \\
\hline Productivity (short tons per miner per hour) . . . . . . . . . & 2.13 & 2.45 & 2.66 & 2.23 & 2.13 \\
\hline Average Mine Price (dollars per short ton) . . . . . . . . . . & 20.82 & $W$ & $W$ & $W$ & $W$ \\
\hline \multicolumn{6}{|l|}{ Total } \\
\hline Quantity (thousand short tons) & 3,760 & 2,985 & 3,487 & 3,773 & 3,341 \\
\hline Mines . . . . . . . . . . . . . . . . . . . . . & 32 & 45 & 27 & 26 & 24 \\
\hline Miners $\ldots \ldots \ldots \ldots \ldots \ldots \ldots \ldots \ldots \ldots \ldots$ & 1,087 & 678 & 589 & 524 & 438 \\
\hline Productivity (short tons per miner per hour) $\ldots \ldots \ldots \ldots \ldots$ & 1.79 & 2.47 & 2.93 & 3.11 & 2.91 \\
\hline Average Mine Price (dollars per short ton) . . . . . . . . . . . & 28.47 & 27.40 & 25.97 & 25.73 & 25.39 \\
\hline
\end{tabular}




\section{Maryland}

Number of Mines by Prod sction Range and Percent of Production, 1992

\begin{tabular}{|c|c|c|c|c|c|c|c|c|}
\hline \multirow{3}{*}{ Mine Type } & \multicolumn{8}{|c|}{ Production Range (thousand short tons) } \\
\hline & \multicolumn{2}{|c|}{1,000 and over } & \multicolumn{2}{|c|}{500 to .799} & \multicolumn{2}{|c|}{100 to 499} & \multicolumn{2}{|c|}{$<100$} \\
\hline & Number & Percent & Number & Percent & Number & Percent & Number & Percent \\
\hline Underground $\ldots \ldots \ldots \ldots \ldots \ldots \ldots \ldots$ & 1 & 99 & 0 & 0 & 0 & 0 & 2 & 1 \\
\hline Surface $\ldots \ldots \ldots \ldots \ldots \ldots \ldots \ldots \ldots$ & $\mathbf{0}$ & 0 & 0 & 0 & 4 & 57 & 17 & 43 \\
\hline All Mines $\ldots \ldots \ldots \ldots \ldots \ldots \ldots \ldots \ldots$ & 1 & 68 & 0 & 0 & 4 & 18 & 19 & 14 \\
\hline
\end{tabular}

\section{Coal Demand}

\begin{tabular}{|c|c|c|c|c|c|}
\hline Diepoaition & 1980 & 1985 & 1980 & 1991 & 1992 \\
\hline \multicolumn{6}{|l|}{ Consumption (thousand short tons) } \\
\hline Electric Utllides . . . . . . . . . . . . . & 5,908 & 7,046 & 8,945 & 8,632 & 9,001 \\
\hline Coke Plents . . . . . . . . . . . . . & 2,645 & $\mathbf{w}$ & $W$ & $\mathbf{W}$ & $W$ \\
\hline Other Industrial $\ldots \ldots \ldots \ldots \ldots \ldots$ & 723 & 718 & 945 & 1,040 & 718 \\
\hline Residential and Commercial ........ & 36 & W & W & $w$ & $W$ \\
\hline Total $\ldots \ldots \ldots \ldots \ldots \ldots \ldots \ldots$ & 9,312 & 10,013 & 11,193 & 10,709 & 9,733 \\
\hline \multicolumn{6}{|l|}{ Year-End Utilty Stocks } \\
\hline (thousand short tons) $\ldots \ldots \ldots \ldots \ldots$ & 1,376 & 1,636 & 2,114 & 2,220 & 2,400 \\
\hline \multicolumn{6}{|l|}{ Electricliy Ceneration } \\
\hline Total (million kilowatthours) . . . . . . . . & 32,174 & 32,300 & 31,497 & 38,215 & 39,426 \\
\hline Coal (percent) $\ldots \ldots \ldots \ldots \ldots \ldots \ldots$ & 45 & 55 & 74 & 59 & 60 \\
\hline Nuclear (percent) $\ldots \ldots \ldots \ldots \ldots \ldots$ & 34 & 31 & 4 & 24 & 27 \\
\hline Other (percent) . . . . . . . . . . & 21 & 14 & 22 & 17 & 13 \\
\hline
\end{tabular}

\section{Utility Coal Data, 1992}

\begin{tabular}{|c|c|c|}
\hline Average Quality and Average Dellvered Cost & Produced in State & Rocolpts, All Sources \\
\hline Heat Content (million Bu per short ton) & 25.13 & 25.51 \\
\hline Sulfur Content (percent by weight) $\ldots \ldots \ldots \ldots \ldots \ldots \ldots$ & 1.69 & 1.36 \\
\hline Ash Content (percent by woight) $\ldots \ldots \ldots \ldots \ldots \ldots \ldots$ & 12.94 & 10.47 \\
\hline Pounds of Sultur per million Btu $\ldots \ldots \ldots \ldots \ldots \ldots \ldots$ & 1.35 & 1.07 \\
\hline Dollars per million Btu $\ldots \ldots \ldots \ldots \ldots \ldots \ldots \ldots \ldots$ & 1.38 & 1.60 \\
\hline Dollars per short ton $\ldots \ldots \ldots \ldots \ldots \ldots \ldots \ldots \ldots$ & 34.66 & 40.68 \\
\hline
\end{tabular}

Estimated Total State Enorgy Consumption, 1901: 1,215 trillion Btu (coal, 275; natural gas, 178; petroleum, 495; nuclear electric power, 97; hydroelectric power, 15; other, 0; net interstate flow of electriclty and sescociated losese, 156).

\footnotetext{
$W=$ Witheld to avoid disclosure of individual company data.
}

Notes: Totals may not equal sum of components because of independent rounding. Data coverage-Productlon: all mines. Number of mines: 1980, mines that produced 10,000 short tons or more; other years, all mines. Number of miners and productivity: mines that produced 10,000 or more short tons and preparation plants that had 5,000 or more employee hours. Average mine price: mines that produced 10,000 or more short tons. Average quality and average dellvered cent of utillty coal: power plants with a generator nameplate capacity of 50 megawatts or more. Extent of coal-bearing areas and locations of coal. consuming plants shown on map are approximate; small coal deposits are not shown. Coal-producing counties shown on map exclude any county where all 1992 output was from mines producing less than 10,000 short tons.

Sources: Energy Information Administration-U.S. Coal Reserves: An Update by Heat and Sulfur Content, February 1993 ; Coal Production 1992 and prior issues; Coal Uata: A Reference; Quarterly Coal Report October-December 1992 and prior issues; Electric Power Annual 1991 and prior issues; Electric Power Monthly, March 1993; Cost and Quality of Fuels for Electric Power Plants 1992; Inventory of Power Plants in the United States 1992; State Energy Data Report 1991: Consumption Estimates; Map of coal-bearing areas is based mainiy on U.S. Geological Survey map. Coalfields of the United States, 1960. Data for historical graph 1890-1975, U.S. Department of the Interior, Geological Survey and Bureau of Mines (Minerals Yearbook and annual predecessor Mineral Resources of the United States): 1976 forward, Energy Information Administration, Coal Production 1992 and prior issues. 


\section{Deetination of Coal Produced in Maryland, 1992}

(Million Short Tons)

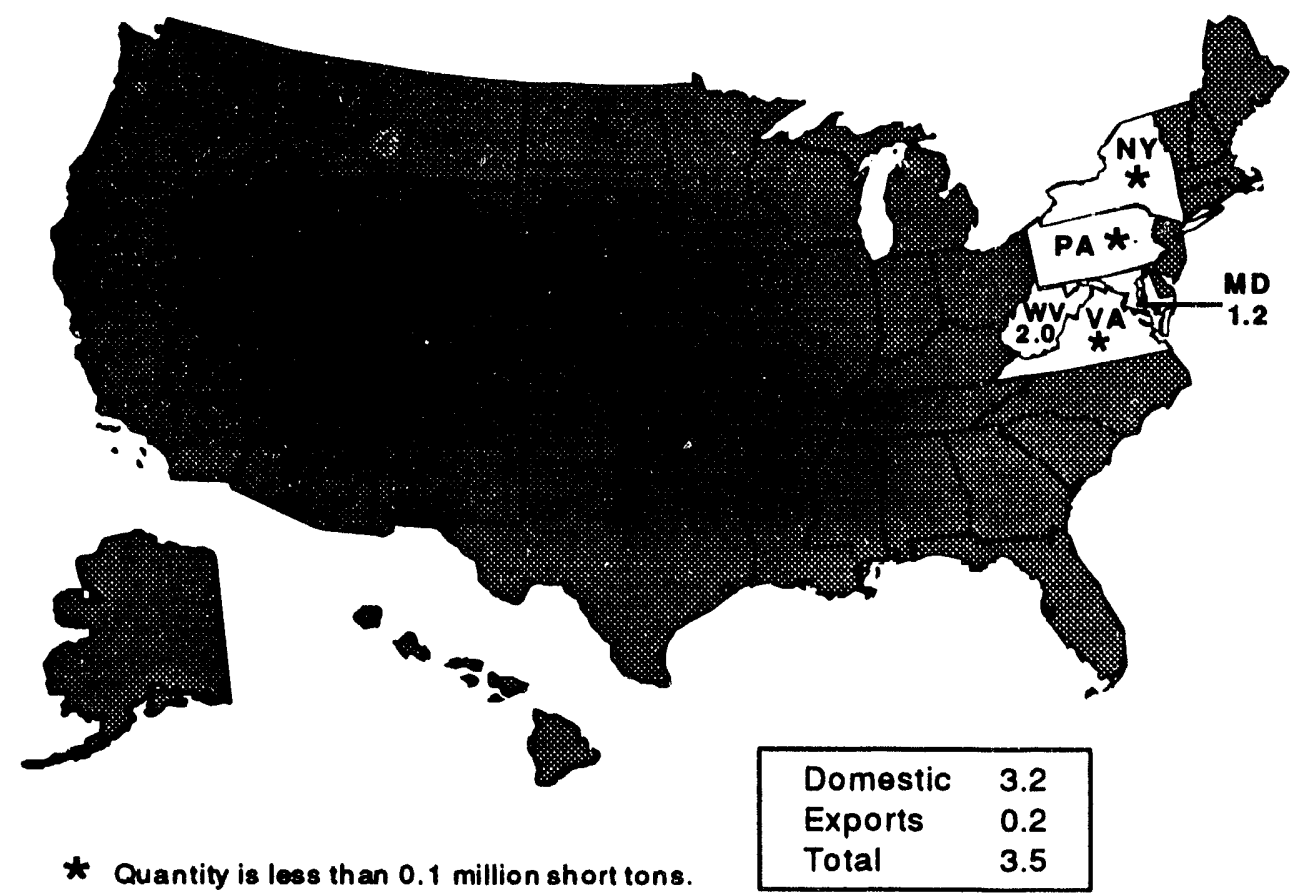

Transportation modes, domestic markets (percent): rail, 67; truck, 30; unknown, 3.

Note: Total may not equal sum of components because of independent rounding.

Source: Energy Information Administration, Form EIA-6, "Coal Distribution Report."

\section{Origin of Coal Recelved in Maryland, 1992}

(Million Short Tons)

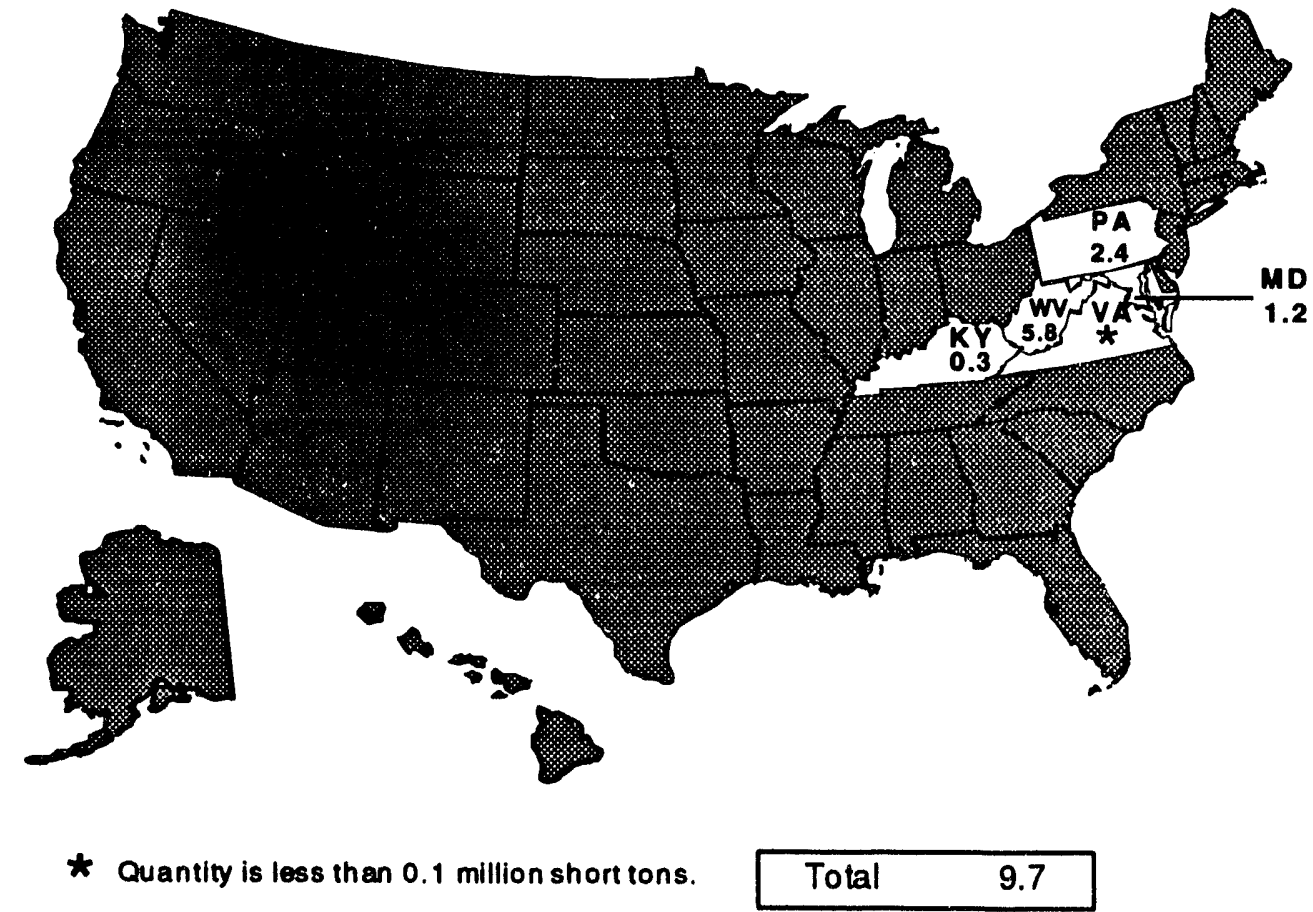

Note: Total may not equal sum of components because of independent rounding.

Source: Energy Information Administration, Form EIA-6, "Coal Distribution Report." 


\section{State Coal Profile: Missouri}

Coal mining is a relatively small industry in Missouri, but coal is the principal mineral fuel produred. In 1992, the value of coal production accounted for an estimated 6 percent of the total value of all mineral commodities produced in the State, including oil and natural gas.

Missouri's coal deposits are in the northern and western parts of the State. The coal, all bituminous in rank, occurs in thin beds. The leading source of coal production from the six beds mined in 1992 was the Bevier coalbed, which averages 3 feet in thickness. Although Missouri's coal has high heat value (averaging about 22 million Btu per short ton), its high sulfur content (averaging about 4 percent by weight) has hindered its use. In addition, the thin coalbeds common in the State are often uneconomical to mine.

Missouri was the first State west of the Mississippi River to produce coal commercially. The occurrence of coal in Missouri appears to have been known as early as 1806, when it was noted on the banks of the Osage River, south of the present site of Prairie City in Bates County. By 1881, coal mining had become a thriving enterprise in the State, with the railroads the largest coal consumers. Production grew to more than 5 million short tons during World War I, and then declined slightly before rising during World War II. The postwar market for Missouri coal fell as coal-burning locomotives were replaced by diesel-electric engines, and the residential use of coal suffered from competition from oil and natural gas. By the early 1970 's, production was trending upward due to the increased use of coal to generate electricity, and in 1984 the coal output reached a record of nearly 7 million short tons. Since then production has fallen, reflecting competition from better quality coal from other States. Missouri's coal production was nearly 3 million short tons in 1992.

Most of the early coal mines in Missouri were underground operations. Surface mining began in the mid-1930's and since the late 1960's it has accounted for virtually all the coal produced in the State. The Thomas Hill surface mine of Associated Electric Coop Inc., in Randolph County, was the State's major coal producer in 1992. Randolph County was the source of nearly 90 percent of Missouri's coal output.

Nearly all of the coal produced in Missouri in 1992 was for consumers in the State. Of the 25 million short tons of coal consumed, however, only about 11 percent was from mines in the State. Electric utilities were by far the largest coal consumers. About half of the utility coal was from Illinois, about one-third was from Wyoming, and most of the balance was from Missouri. The largest coal-fired generating units, totaling 2,232 megawatts, are at the Labadie Power Plant of Union Electric Company, in Franklin County. Most of the coal consumed by other industries, mainly cement and lime plants, was from other States. 


\section{Missouri}

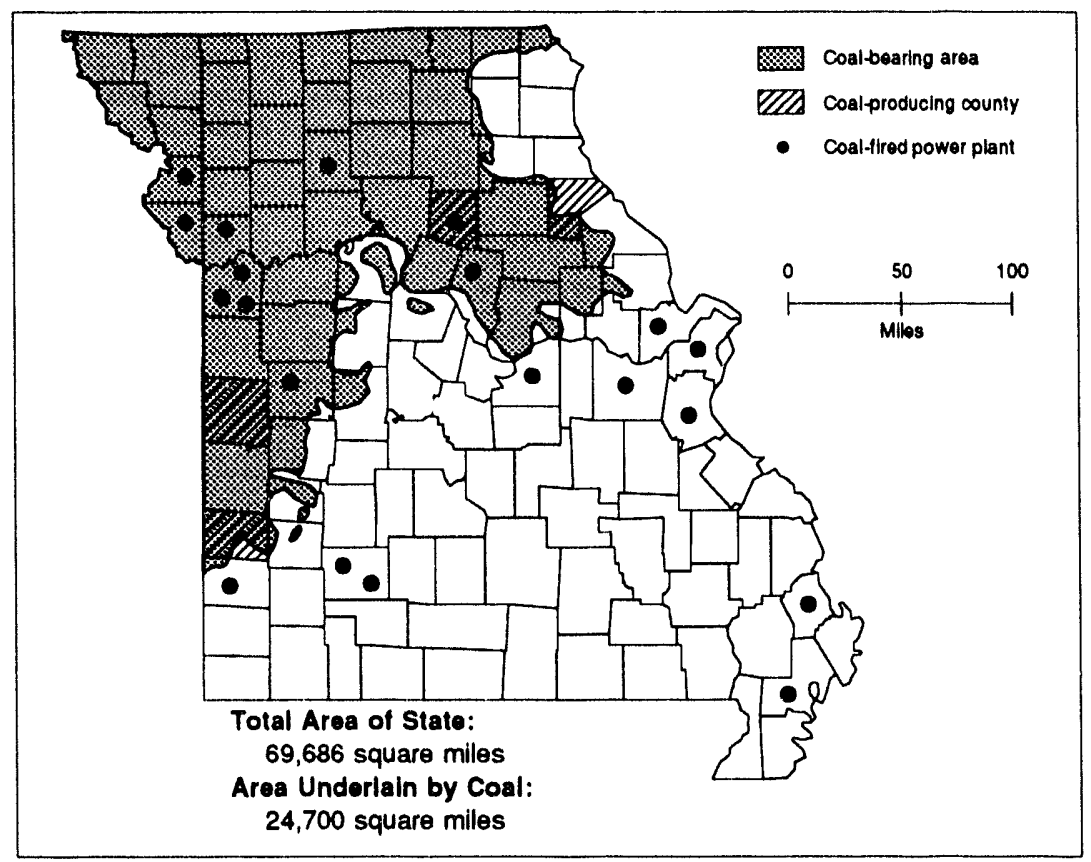

Coal Production, 1890-1992

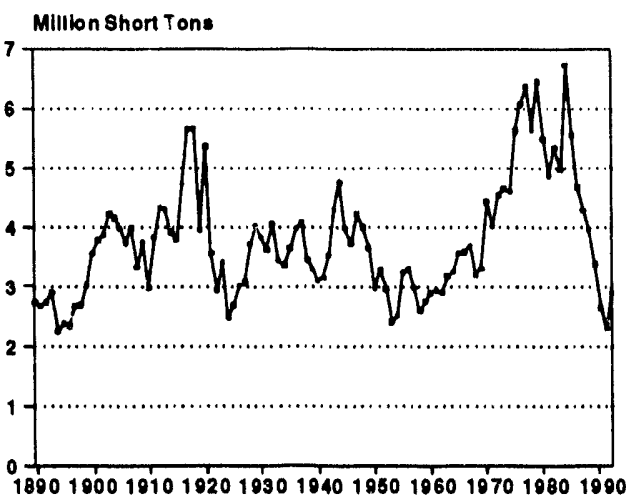

First Yoar of Documented Coal

Production . . . . . . . . . 1840 (9,972 short tons) Peak Year of Coal

Production . . . . . . . 1984 (6,733,000 short tons)

Coal Reserves (Million Short Tons)

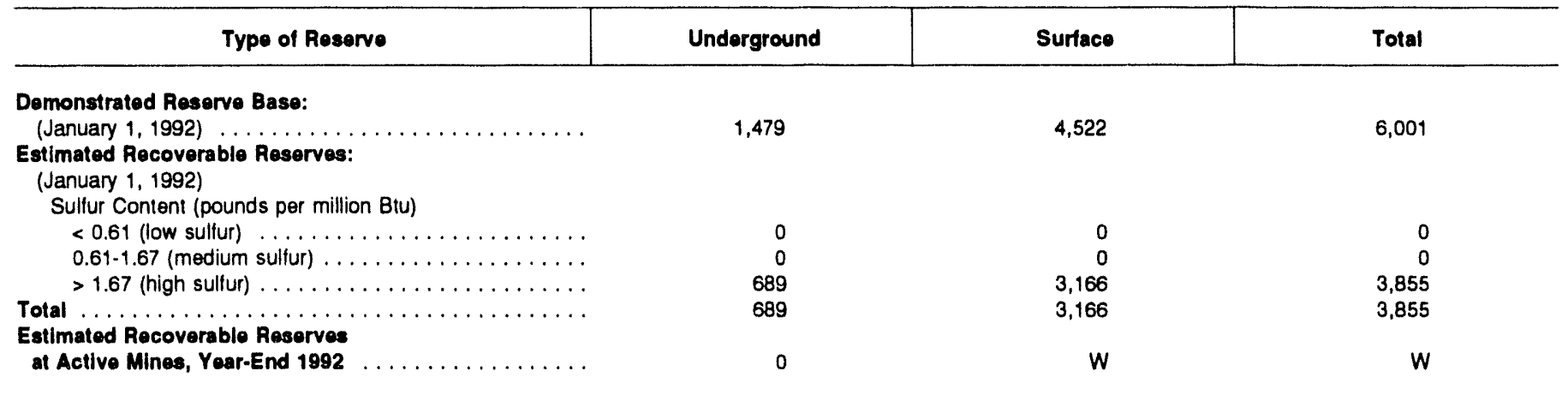

\section{Production}

\begin{tabular}{|c|c|c|c|c|c|}
\hline Sallent Data by Mine Type & 1980 & 1985 & 1990 & 1991 & 1992 \\
\hline \multicolumn{6}{|l|}{ Underground } \\
\hline Quantity (thousand short tons) $\ldots \ldots \ldots \ldots \ldots \ldots$ & 0 & 5 & 0 & 0 & 0 \\
\hline 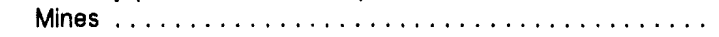 & 0 & 1 & 0 & 0 & 0 \\
\hline Miners $\ldots \ldots \ldots \ldots \ldots \ldots \ldots \ldots \ldots \ldots \ldots \ldots$ & 0 & NA & 0 & 0 & 0 \\
\hline Productivity (shon tons per miner per hour) $\ldots \ldots \ldots \ldots$ & -- & NA & -- & -- & -. \\
\hline Average Mine Price (dollars per shor ton) . . . . . . . . . & $\cdots$ & NA & $\cdots$ & $\cdots$ & $-\cdot$ \\
\hline \multicolumn{6}{|l|}{ Surtace } \\
\hline Quantity (thousand short tons) $\ldots \ldots \ldots \ldots \ldots \ldots$ & 5,503 & 5,566 & 2,647 & 2,304 & 2,886 \\
\hline Mines $\ldots \ldots \ldots \ldots \ldots \ldots \ldots \ldots \ldots \ldots \ldots \ldots \ldots \ldots$ & 13 & 14 & 5 & 5 & 5 \\
\hline Miners $\ldots \ldots \ldots \ldots \ldots \ldots \ldots \ldots \ldots \ldots \ldots$ & 1,093 & 1,108 & 347 & 312 & 323 \\
\hline Productivity (shor tons per miner per hour) $\ldots \ldots \ldots \ldots \ldots$ & 2.34 & 2.28 & 2.99 & 2.69 & 3.10 \\
\hline Average Mine Price (dollars per short ton) . . . . . . . . . . & 20.50 & 27.08 & $W$ & W & $W$ \\
\hline \multicolumn{6}{|l|}{ Total } \\
\hline Quantity (thousand short tons) & 5,503 & 5,571 & 2,647 & 2,304 & 2,886 \\
\hline 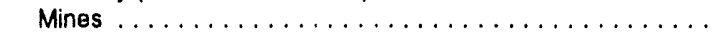 & 13 & 15 & 5 & 5 & 5 \\
\hline Miners $\ldots \ldots \ldots \ldots \ldots \ldots \ldots \ldots \ldots \ldots \ldots$ & 1,093 & 1,108 & 347 & 312 & 323 \\
\hline Productivity (short tons per miner per hour) $\ldots \ldots \ldots \ldots \ldots$ & 2.34 & 2.28 & 2.99 & 2.69 & 3.10 \\
\hline Average Mine Price (dollars per short ton) $\ldots \ldots \ldots \ldots \ldots$ & 20.50 & 27.08 & W & W & W \\
\hline
\end{tabular}


Missourl

Number of Mines by Production Range and Percent of Production, 1992

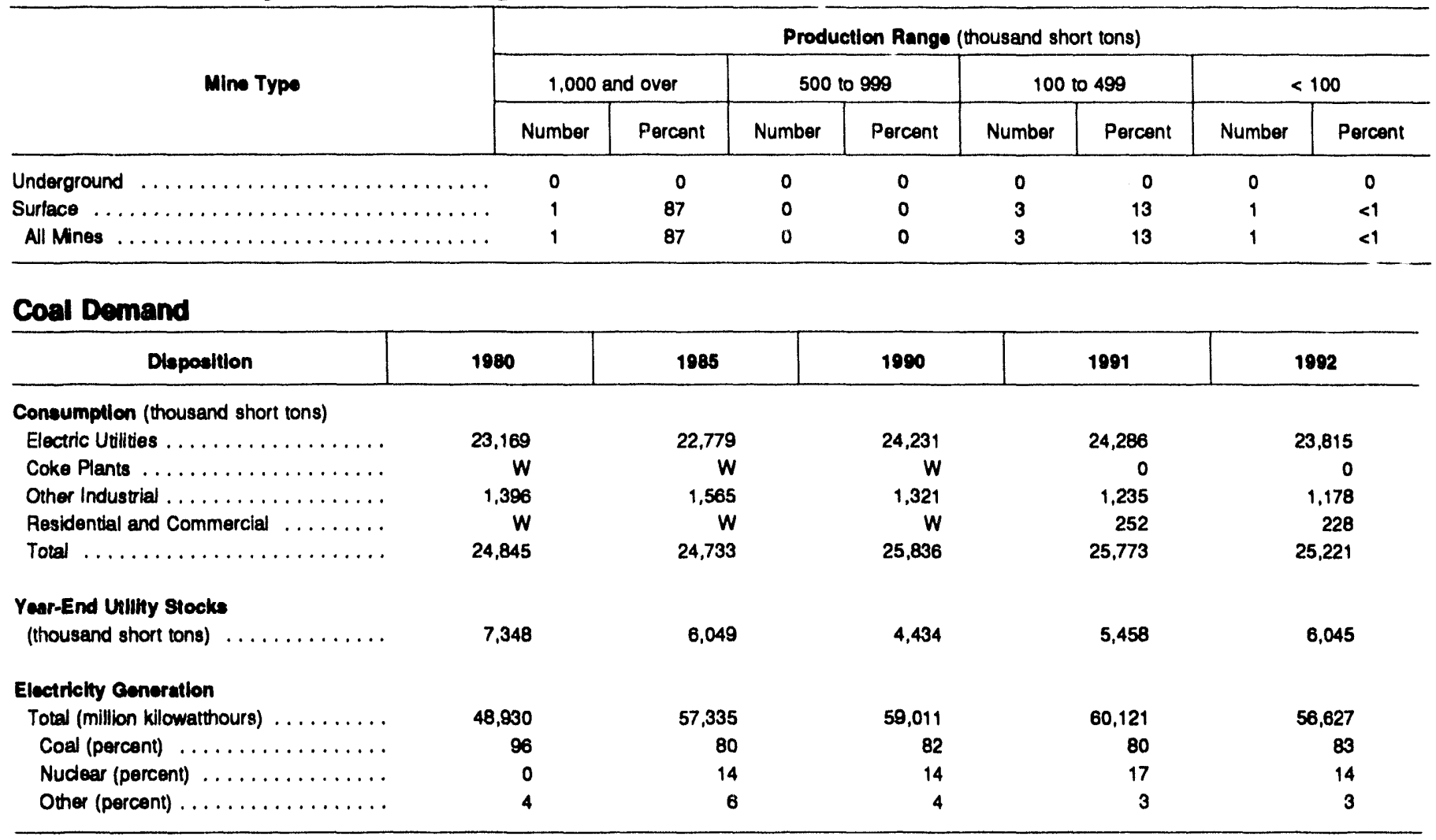

Utility Coal Data, 1992

\begin{tabular}{|c|c|c|}
\hline Average Qualty and Average Dellvered Cost & Produced in State & Recolpts, All Sources \\
\hline Heat Content (million Btu per short ton) & 21.18 & 20.64 \\
\hline Sulfur Content (percent by weight) $\ldots \ldots \ldots \ldots \ldots \ldots \ldots$ & 4.15 & 1.80 \\
\hline Ash Content (percent by weight) $\ldots \ldots \ldots \ldots \ldots \ldots \ldots$ & 10.22 & 7.71 \\
\hline Pounds of Sulfur per million $B t u \ldots \ldots \ldots \ldots \ldots \ldots \ldots \ldots$ & 3.92 & 1.74 \\
\hline Dollars per million Btu .. & 1.63 & 1.34 \\
\hline Dollars per short ton $\ldots \ldots \ldots \ldots \ldots \ldots \ldots \ldots \ldots \ldots$ & 34.43 & 27.57 \\
\hline
\end{tabular}

Estimated Total State Energy Consumption, 1991: 1,513 trillien Btu (coal, 535; natural ges, 259; potroloum, 622; nuclear olectric powor, 107; hydroelectric power, 11; other, 0 ; net interatate how of electrictly and associated losees, -21).

$W=$ Withheld to avoid disclosure of individual company data.

NA = Not available.

Notes: Totals may not equal sum of components because of independent rounding. Data coverage-Production: all mines. Number of mines: 1980 , mines that produced 10,000 short tons or more; other years, all mines. Number of miners and productlvity: mines that produced 10,000 or more short tons and preparation plants that had 5,000 or more employee hours. Average mine price: mines that produced 10,000 or more short tons. Average quality and average delivered coet of utllity coal: power plants with a generator nameplate capadity of 50 megawatts or more. Extent of coal-bearing areas and locations of coalconsuming plants shown on map are approximate; small coal deposits are not shown. Coal-producing counties shown on map exclude any county where all 1992 output was from mines producing less than 10,000 short tons.

Sources: Energy information Administration-U.S. Coal Reserves: An Update by Heat and Sulfur Content, February 1993; Coal Production 1992 and prior issues; Coal Data: A Reference; Quarterly Coal Report October-December 1992 and prior issues; Electric Power Annual 1991 and prior issues; Electric Power Monthly. March 1993; Cost and Quality of Fuels for Electric Power Plants 1992; Inventory of Power Plants in the United States 1992; State Energy Data Report 1991: Consumption Estimates; Map of coal-bearing areas is based mainly on U.S. Geological Survey map, Coalfields of the United States, 1960. Data for historical graph 1890-1975, U.S. Department of the Interior, Geological Survey and Bureau of Mines (Minerals Yearbook and annual predecessor Mineral Resources of the United States); 1978 forward, Energy Information Administration, Coal Production 1992 and prior issues. 
Destination of Coal Produced In Missourl, 1992

(Million Short Tons)

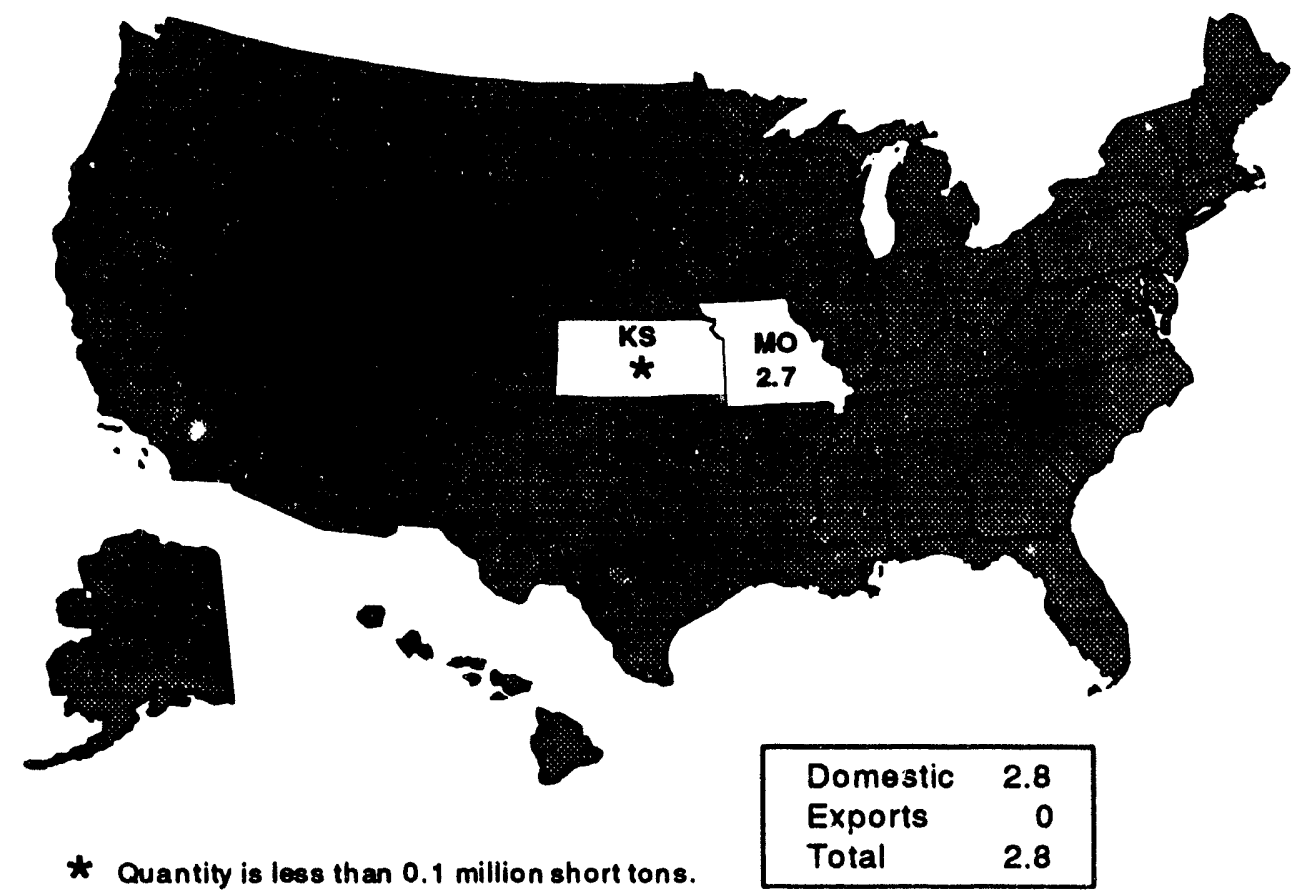

Transportation modes, domestic markets (percent): rail, 3; truck, 10; tramway/conveyor, 86; unknown, $<1$.

Note: Total may not equal sum of components because of independent rounding.

Source: Energy Information Administration, Form EIA-6, "Coal Distribution Report."

\section{Origin of Coal Recelved in Missourt, 1992}

(Million Short Tons)

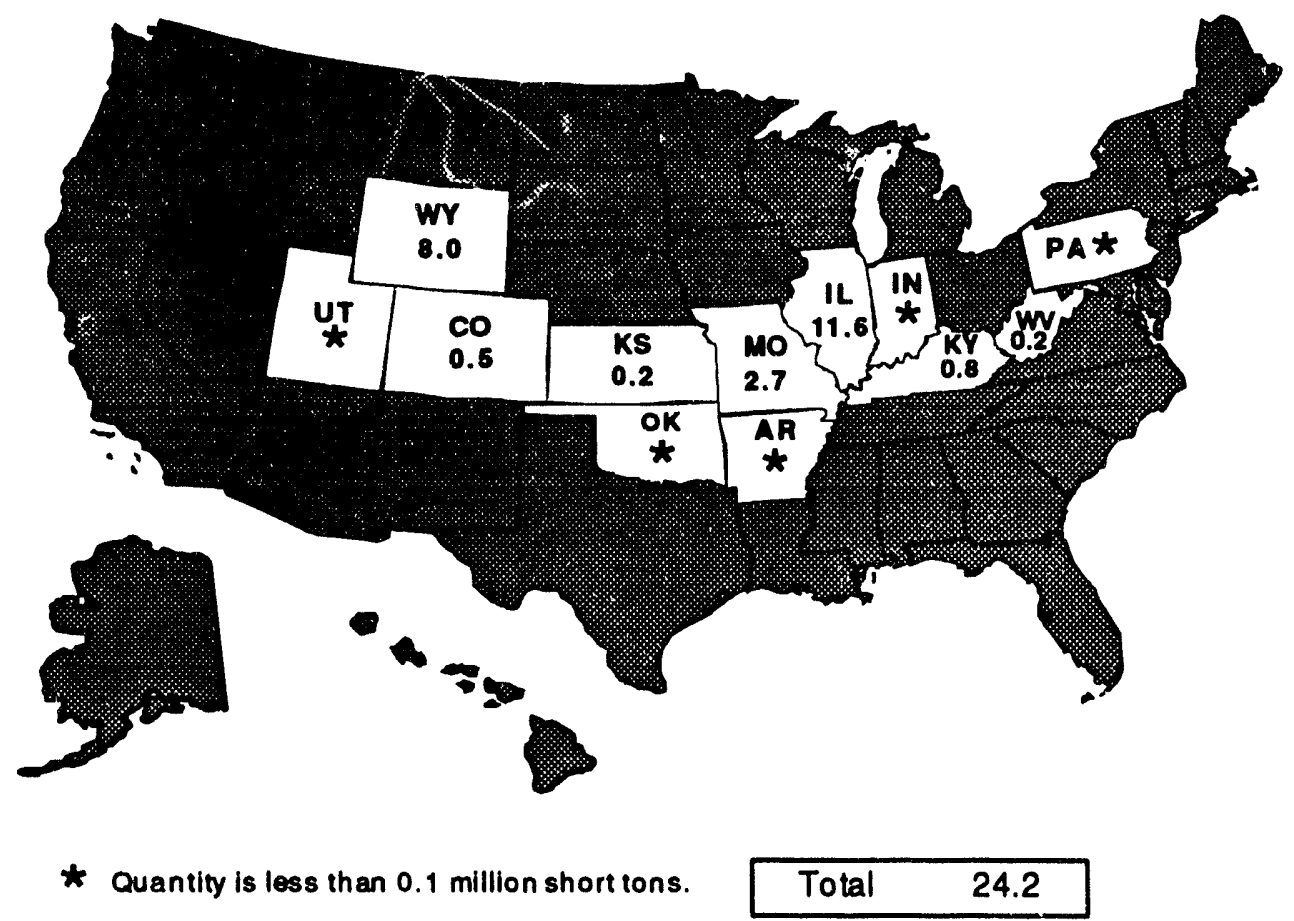

Note: Total may not equal sum of components because of independent rounding.

Source: Energy Information Administration, Form EIA-6, "Coal Distribution Report." 


\section{State Coal Profile: Montana}

Coal was estimated to be the leading mineral commodity produced in Montana in 1992. It accounted for more than one-fourth of the estimated total value of all minerals produced, ranking slightly higher than crude oil. Royalties from Federal coal leases generated $\$ 34$ million, which was disbursed equally to the State and the Federal Government. Royalties from a coal lease granted by the Crow Tribe were over $\$ 1$ million.

Coal deposits are widely distributed across Montana, together comprising the Nation's largest coal reserve base. The ranks of coal include lignite, subbituminous, and bituminous. Production, however, is nearly all lowsulfur subbituminous coal, with a small amount of lignite. The major source of subbituminous coal, accounting for about half of the State's production, is the Rosebud coalbed. This coalbed, which ranges up to 30 feet in thickness, is in the Powder River Basin, located in the southeastern part of the State.

Coal was reportedly first used in Montana in 1807, by a Spanish fur trader who used to heat his outpost. Montana's coal industry began on a small scale in 1880 , and by 1900 it was well established. The bulk of production was for railroad fuel. Lesser amounts were for heating and to produce coke for smelting. Production rose to nearly 5 million short tons in 1918. It then declined to an average of about 3 million short tons annually, rising slightly during World War II. The relative stability of Montana's coal output during those three decades reflects the small level of industrial development in the State, the development of its hydroelectric and petroleum resources, and competition with coal from other States and with other fuels.

In the 1950 's and 1960's, Montana's coal production fell sharply due to the replacement of coal-fired locomotives by diesel-electric locomotives and an abundant supply of natural gas. The 1970's brought about a significant increase in production due largely to the construction of the large Colstrip coal-fired power plant in Rosebud County. Over the next decade, coal production continued to rise as the plant added generating units. Additional demand for Montana's low-sulfur coal by utilities in other States was spurred by the enactment of Federal regulatio: ss on emissions. In 1992, Montana's coal output reached a record of 39 million short tons.

Early coal production in Montana was mostly from underground mines. Large-scale surface mining began in the 1920's at Colstrip, Rosebud County, where the Rosebud seam was covered by 20 to 50 feet of overburden. By 1930, the Colstrip mine accounted for more than one-third of the State's coal output. For about the past two decades, virtually all of Montana's coal has been produced by surface mining. The largest mine in 1992 was the Rosebud mine of Western Energy Company, in Rosebud County. Its output of more than 14 million short tons ranked it as the fifth-largest U.S. coal mine. The State's only lignite producer is the Savage Strip Mine of Knife River Coal Company, in Richland County. Nearly all of Montana's coal production is from Big Horn and Rosebud counties. In 1992, more than 60 percent of the State's production was from Federal coal leases, about 6 percent was from Crow Indian leases, with the balance from State and private lands.

More than two-thirds of Montana's 1992 coal output was shipped out of State, including a small amount for overseas customers. The major destinations were electric utilities in Michigan and Minnesota. The 11 million short tons of coal consumed in Montana in 1992 was nearly all for generating electricity, and all of the utility coal used was produced in the State. Montana's largest coal-fired generating units, totaling 2,060 megawatts, are at the Colstrip plant of Montana Power Company, in Rosebud County. A small amount of coal was also used in the State for processing sugar cane and manufacturing cement. 


\section{Montana}

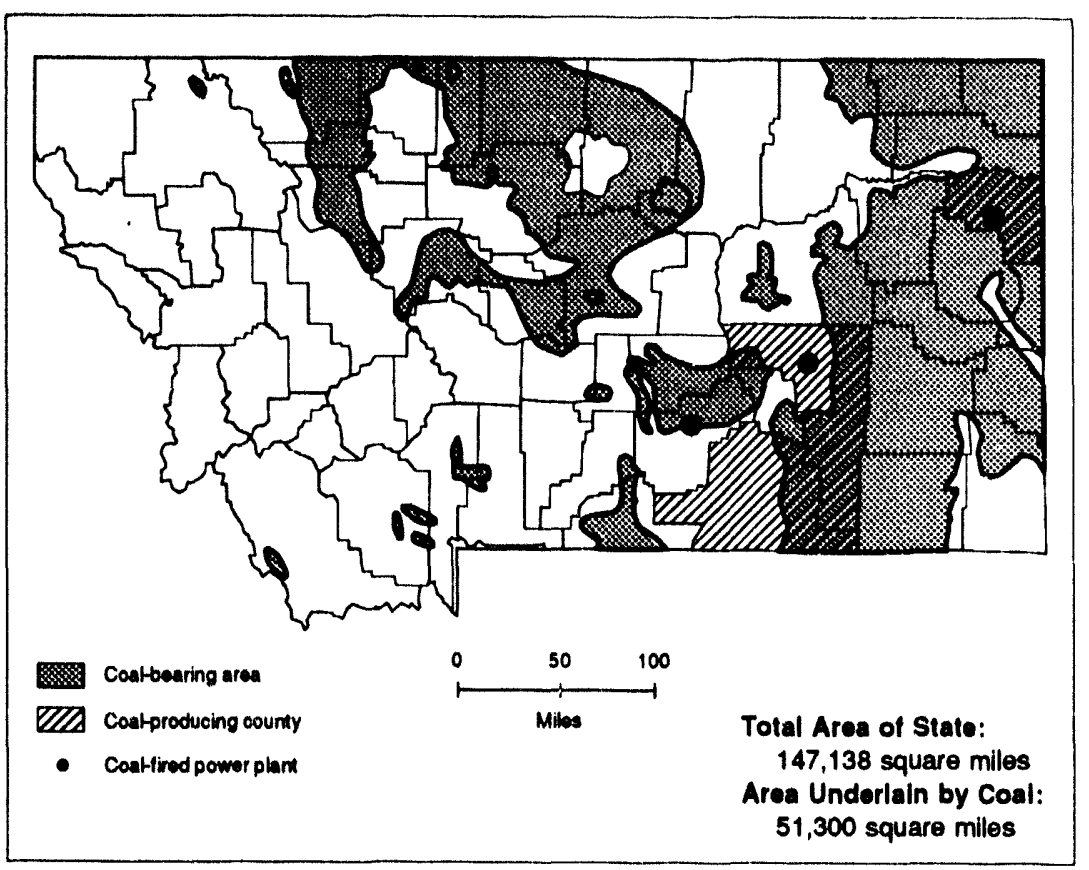

Coal Production, 1890-1892

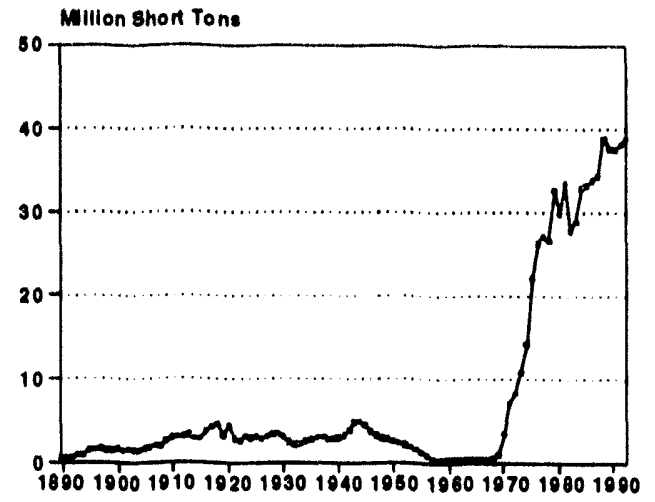

Firat Year of Documented Coal

Production . . . . . . . . . . . . . 1880 (224 short tons)

Peak Year of Coal

Productlon . . . . . . . . . . 1992 (38,889,000 short tons)

Coal Reserves (Million Short Tons)

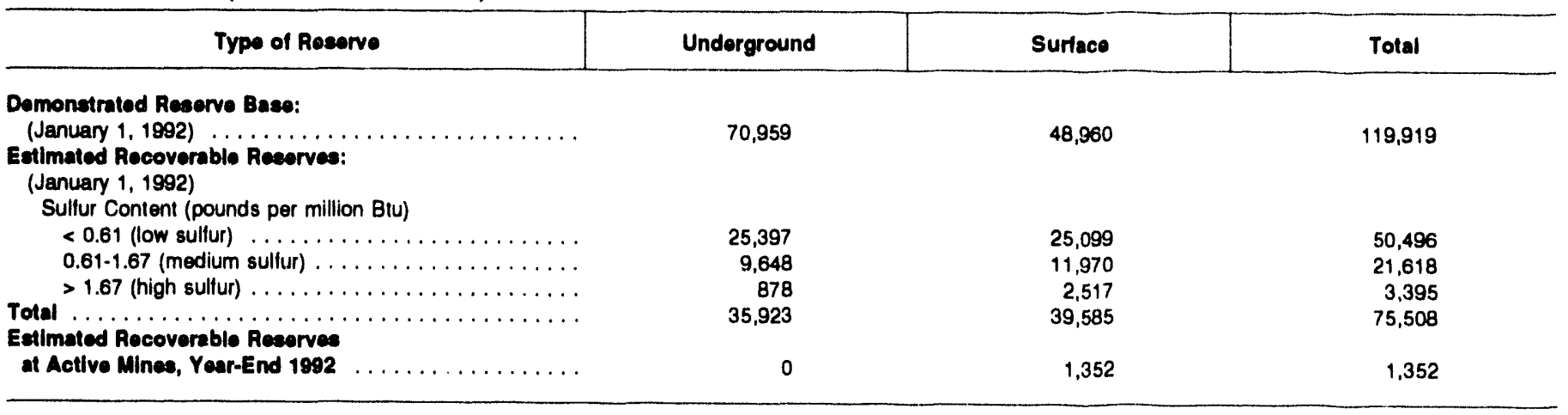

\section{Production}

\begin{tabular}{|c|c|c|c|c|c|}
\hline Salient Data by Mine Typo & 1980 & 1985 & 1990 & 1991 & 1992 \\
\hline \multicolumn{6}{|l|}{ Underground } \\
\hline Quantity (thousand short tons) $\ldots \ldots \ldots \ldots \ldots \ldots$ & 0 & 0 & 0 & 3 & 10 \\
\hline 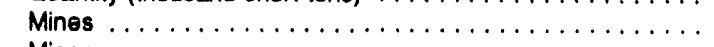 & 0 & 0 & 0 & 1 & 1 \\
\hline 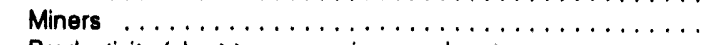 & 0 & 0 & 0 & NA & NA \\
\hline Productivity (shon tons per miner per hour) $\ldots \ldots \ldots \ldots \ldots$ & $\cdots$ & .. &.- & NA & NA \\
\hline Average Mine Price (dollars per short ton) $\ldots \ldots \ldots \ldots \ldots$ & $\cdots$ & $\cdots$ & 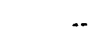 & NA & NA \\
\hline \multicolumn{6}{|l|}{ 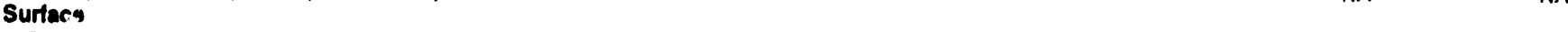 } \\
\hline Quantity (thousand short tons) $\ldots \ldots \ldots \ldots \ldots \ldots$ & 29,872 & 33,290 & 37,616 & 38,235 & 38,879 \\
\hline Mines $\ldots \ldots \ldots \ldots \ldots \ldots \ldots \ldots \ldots \ldots \ldots \ldots$ & 9 & 9 & 9 & 8 & 7 \\
\hline Miners $\ldots \ldots \ldots \ldots \ldots \ldots \ldots \ldots \ldots \ldots \ldots$ & 1,131 & 1,173 & 821 & 794 & 715 \\
\hline Productivity (shon tons per miner per hour) $\ldots \ldots \ldots \ldots \ldots$. & 11.98 & 14.73 & 18.78 & 18.99 & 20.16 \\
\hline Average Mine Price (dollars per short ton) $\ldots \ldots \ldots \ldots \ldots$ & 10.50 & 13.18 & 9.42 & 10.76 & 10.20 \\
\hline \multicolumn{6}{|l|}{ Total } \\
\hline Quantity (thousand short tons) $\ldots \ldots \ldots \ldots \ldots \ldots \ldots$ & 29,872 & 33,290 & 37,616 & 38,237 & 38,889 \\
\hline Mines $\ldots \ldots \ldots \ldots \ldots \ldots \ldots \ldots \ldots \ldots \ldots \ldots$ & 9 & 9 & 9 & 9 & 8 \\
\hline Miners $\ldots \ldots \ldots \ldots \ldots \ldots \ldots \ldots \ldots \ldots \ldots$ & 1,131 & 1,173 & 821 & 794 & 715 \\
\hline Productivity (shon tons per miner per hour) $\ldots \ldots \ldots \ldots \ldots$ & 11.98 & 14.73 & 18.78 & 18.99 & 20.16 \\
\hline Average Mine Price (dollars per short ton) $\ldots \ldots \ldots \ldots \ldots$ & 10.50 & 13.18 & 9.42 & 10.76 & 10.20 \\
\hline
\end{tabular}


Montana

Number of Mines by Production Range and Percont of Production, 1992

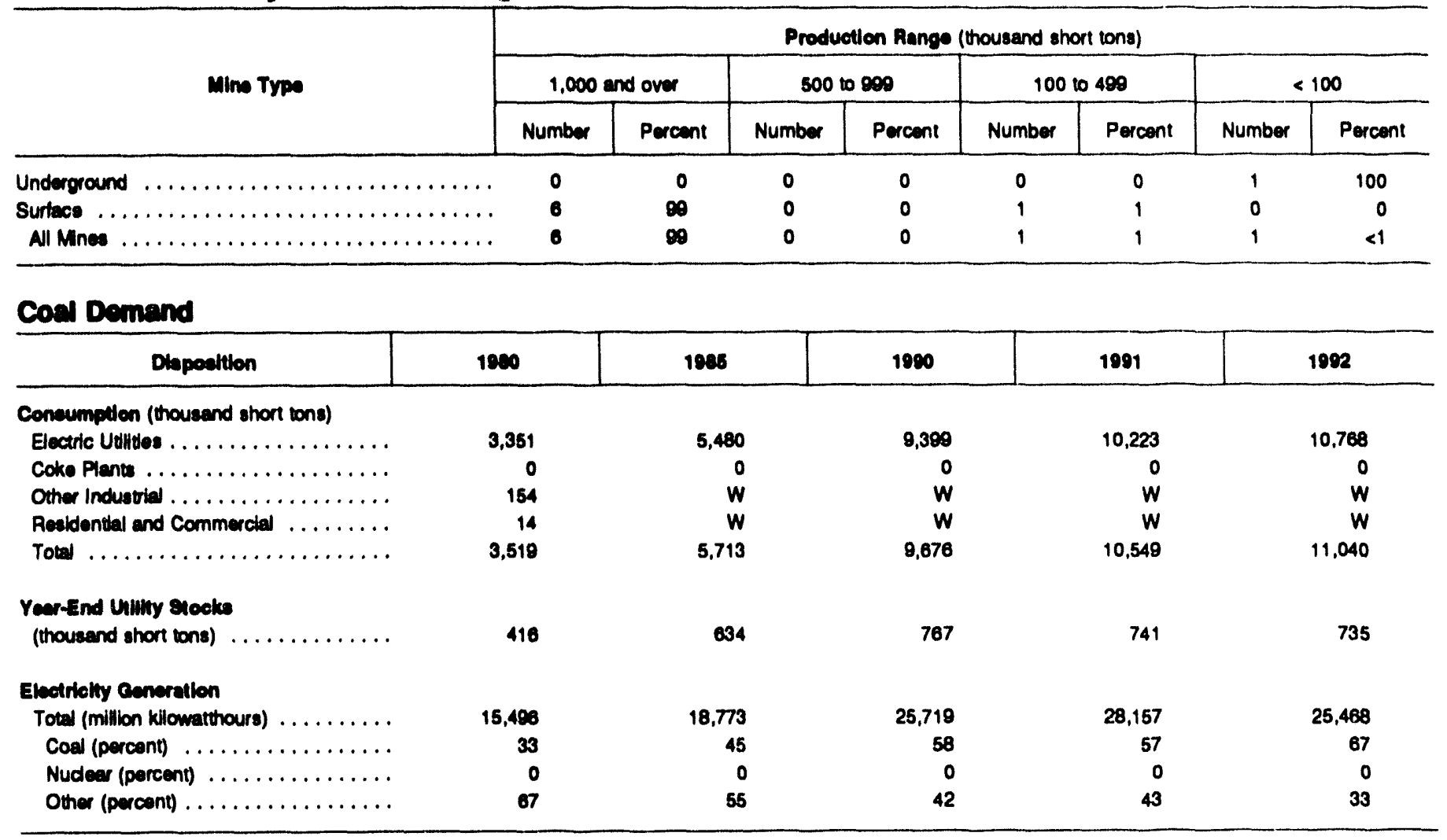

\section{Utility Coal Data, 1992}

\begin{tabular}{|c|c|c|}
\hline Averwere Cuallty and Average Delivered Coed & Produced In State & Rocelpts, All Sources \\
\hline Heat Content (million Btu per short ton) $\ldots \ldots \ldots \ldots \ldots \ldots \ldots$ & 18.10 & 17.15 \\
\hline Sulfur Content (percent by weight) $\ldots \ldots \ldots \ldots \ldots \ldots \ldots \ldots$ & .52 & .66 \\
\hline Ash Content (percent by woight) $\ldots \ldots \ldots \ldots \ldots \ldots \ldots \ldots$ & 6.62 & 8.92 \\
\hline Pounds of Sultur per million Btu $\ldots \ldots \ldots \ldots \ldots \ldots \ldots \ldots$ & .57 & .77 \\
\hline Dollars per million Btu $\ldots \ldots \ldots \ldots \ldots \ldots \ldots \ldots$ & 1.33 & .71 \\
\hline Dollars per short ton $\ldots \ldots \ldots \ldots \ldots \ldots \ldots \ldots \ldots$ & 24.12 & 12.14 \\
\hline
\end{tabular}

Eetimated Total state Energy Consumption, 1901: 342 trllion Btu (coel, 180; natural ges, 47; petrobum, 145; nuclear electric powor, 0; hydroalectrie power, 124; other, 1; not interdate flow of clectriclty and accociated loceces, -154).

W - Witheld to avold disclosure of individual company data.

NA = Not available.

Notes: Totele may not equal sum of components because of independent rounding. Date coverage-Production: all mines. Number of mines: 1980 , mines that produced 10,000 short tons or more; other years, all mines. Number of miners and productivity: mines that produced 10,000 or more short tons and preparation plants that had 5,000 or more employee hours. Averege mine price: mines that produced 10,000 or more short tons. Avurage quality and average dellivered coet of utility coal: power plants with a penerator nameplate capacity of 50 megawatts or more. Extent of coal-bearing areas and locations of coalconsuming plants shown on map are approximate; small coal deposits are not shown. Coat-producing counties shown on map exclude any county where all 1982 output was from mines producing less than 10,000 short wons.

Sources: Energy Intormation Administration-U.S. Coal Reserves: An Update by Heat and Sulfur Content, February 1993; Coal Production 1992 and prior 18sues; Coel Data: A Reference; Quantenty Coal Report October-December 1982 and prior issues; Electric Power Annual 1991 and prior issues; Electric Power Monthly, March 1993; Cost and Qually of Fuels for Eloctric Power Plants 1992; Inventory of Power Plants in the United States 1992; State Energy Data Report 1991: Consumption Estimates; Map of cost-bearing areas is based mainly on U.S. Geological Survey map, Coalfields of the United States, 1960. Data tor historical graph 1800-1975, U.S. Deparment of the Interior, Geological Survey and Bureau of Mines (Minerals Yearbook and annual predecessor Mineral Resources of the United States); 1976 tonward. Energy Information Administration, Coal Production 1992 and prior issues. 
Destination of Coal Produced In Montana, 1992

(Million Short Tons)

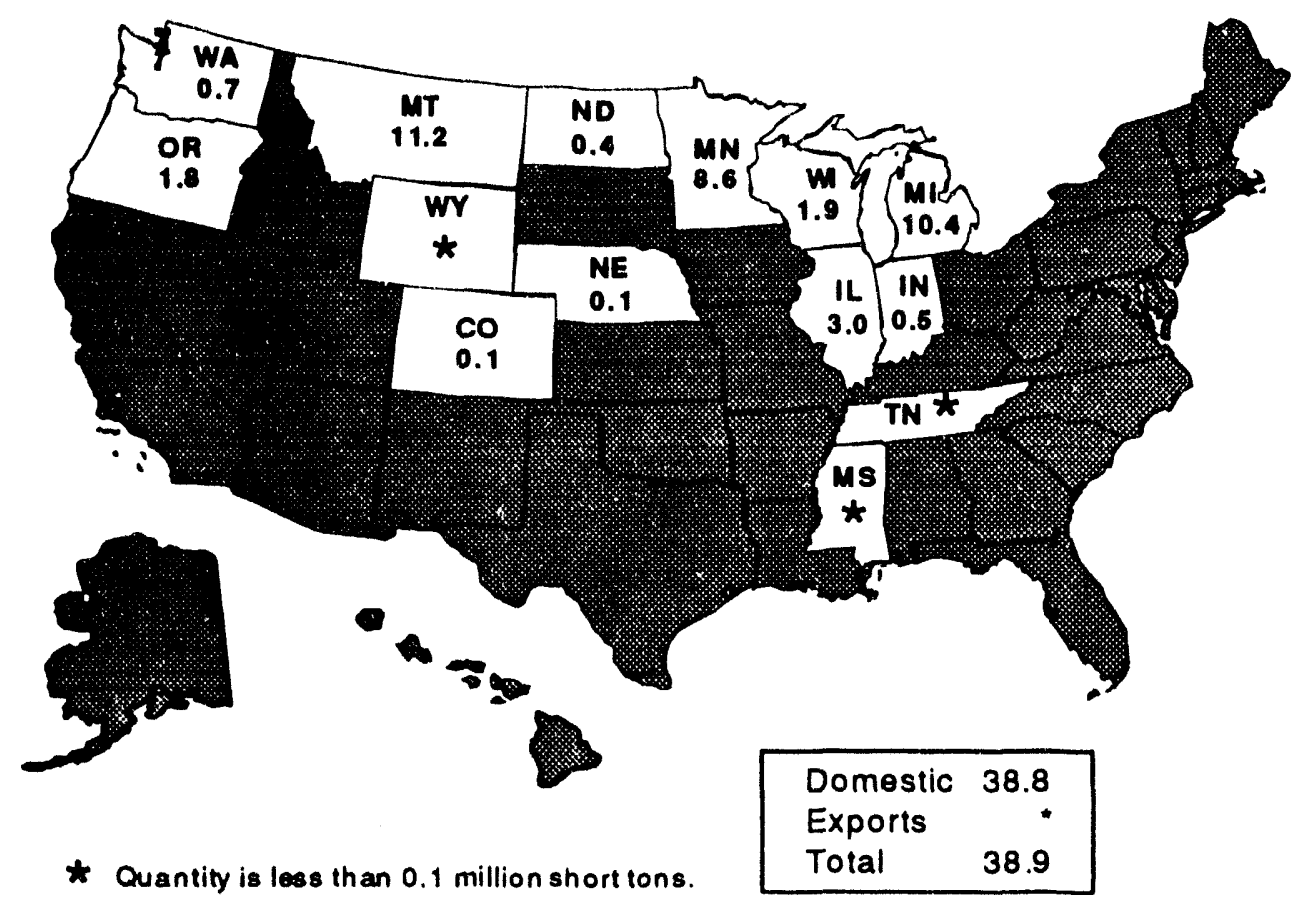

Transportation modes, domestic markets (percent): rail, 57; water, 16; truck, <1; tramway/conveyor, 26; unknown, $<1$.

Note: Total may not equal sum of components because of independent rounding.

Source: Energy Information Administration, Form EIA-6, "Coal Distribution Report."

Origin of Coal Recelved in Montana, 1992

(Milion Shont Tons)

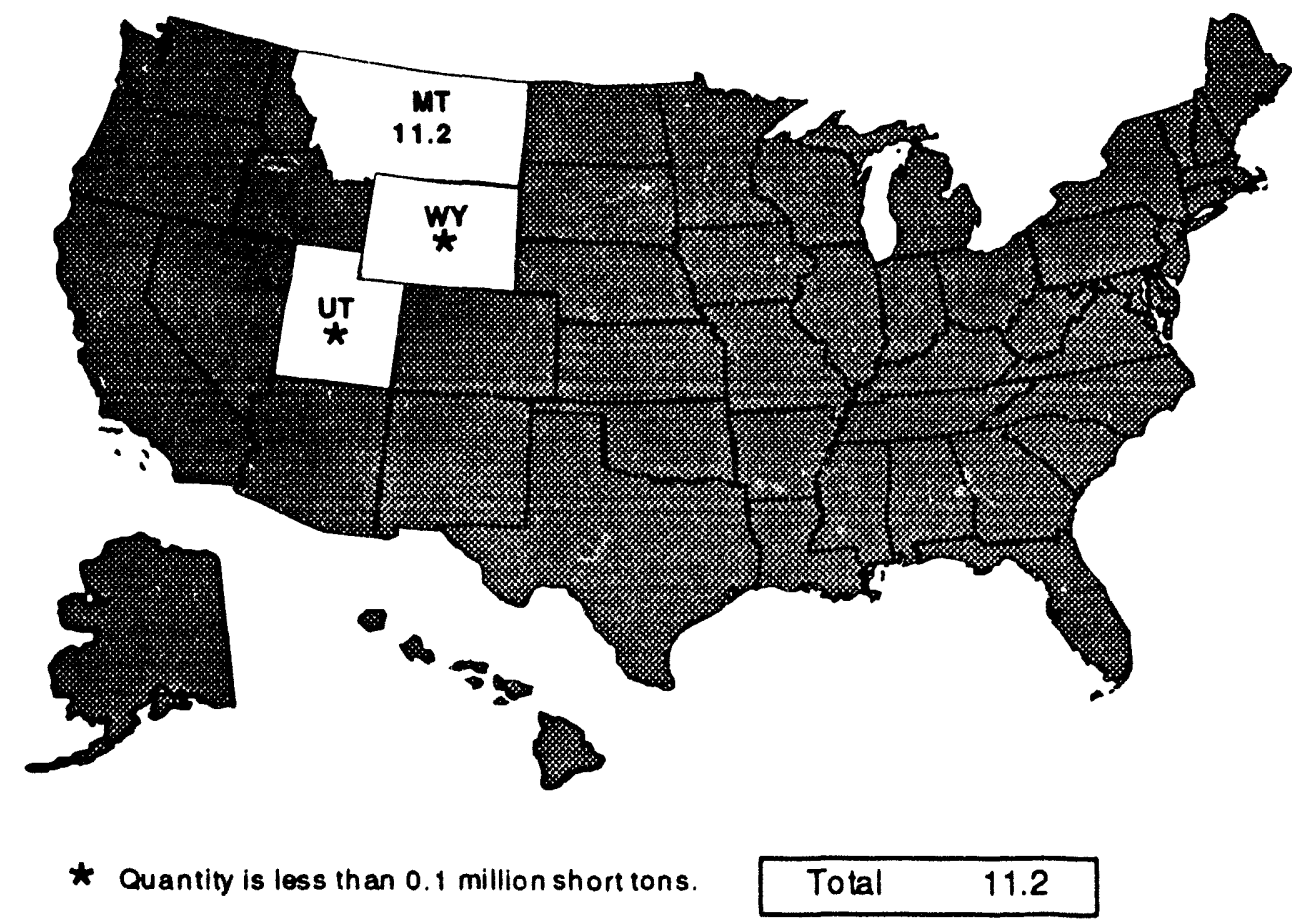

Note: Total may not equal sum of components because of independent rounding.

Source: Energy Information Administration, Form EIA-6, "Coal Distribution Report." 


\section{State Coal Profile: New Mexico}

Coal is one of four mineral fuels produced in New Mexico. In 1992, New Mexico's coal output was estimated to account for around 10 percent of the total value of all mineral commodities produced in the State. Crude oil and natural gas were by far the leading mineral commodities; the value of uranium production was small. Royalties from Indian and Federal coal leases totaled about $\$ 32$ million and $\$ 14$ million, respectively. Federal royalties were disbursed equally to the State and the Federal Government.

The principal coal-bearing areas in New Mexico are the San Juan and Raton basins, both in the northern part of the State. The San Juan Basin, the larger of the two, is the major source of coal production. San Juan Basin coal, which has a low sulfur content, ranges in rank from subbituminous in the South to bituminous in the North. About 18 coalbeds were mined in 1992, but most production was largely from the Fruitland Formation, which contains several coalbeds. The beds mined are generally 4 to 13 feet thick. The Raton Basin contains low-sulfur bituminous coal, including some that can be used to produce metallurgical coke. Coking coal was mined in the Raton Basin until 1986 and shipped primarily to a coke plant in California. The minable beds in the Raton Basin average over 5 feet in thickness.

Small amounts of the coal in New Mexico reportedly were used several centuries ago by Spanish explorers, and in the 1860 's by the U.S. Army at Fort Craig, near present-day Socorro. The first commercial coal production was to supply fuel for railroads, metallic ore smelteri, domestic and commercial heating, and small power plants. Until the $1920^{\prime}$ s, some coal was converted into coke in beehive ovens, principally for use in smelting copper. Around the same time, some coal from the Raton field was used to manufacture coal gas.

New Mexico's coal output rose to about 4 million short tons in 1918 and then slackened as many mines closed, due chiefly to competition from natural gas and crude oil produced in New Mexico and in neighboring States. Over the next 40 years, production trended downward, eventually falling below 1 million short tons in the 1950 's and early 1960's. In the late 1960's the State's coal industry was re-established with the opening of large mines to supply fuel for new coal-burning power plants built in New Mexico and Arizona to meet the growing demand for electricity in the Southwest. Rising almost steadily, New Mexico's coal production reached an all-time high of 25 million short tons in 1992.

Underground mines were the chief source of coal production in New Mexico until the mid-1960's, when large surface mines were opened. Virtually all production in recent years has been from surface mines. The State's largest coal mine in 1992, with an output of about 9 million short tons, was the Navajo surface mine of BHP Minerals International Incorporated, in San Juan County. The mine produces from leases on Navajo land. Of the total coal produced in New Mexico in 1992, a little more than half was from Indian coal leases and about 15 percent was from Federal coal leases, with the balance from State and private lands. San Juan and McKinley counties were the source of nearly all of New Mexico's coal output.

Coal is produced in New Mexico mainly for electric utilities. In 1992, about 60 percent was for power plants in the State, and most of the balance was shipped to Arizona. Virtually all of the 15 million short tons of coal consumed in New Mexico was for generating electricity. The State's largest coal-fired power plant is the 2,040-megawatt Four Corners plant, operated by Arizona Public Service in San Juan County. The plant receives coal from the Navajo surface mine, about 12 miles away. A small amount of coal was also used at a cement plant in the State. 


\section{New Mexico}

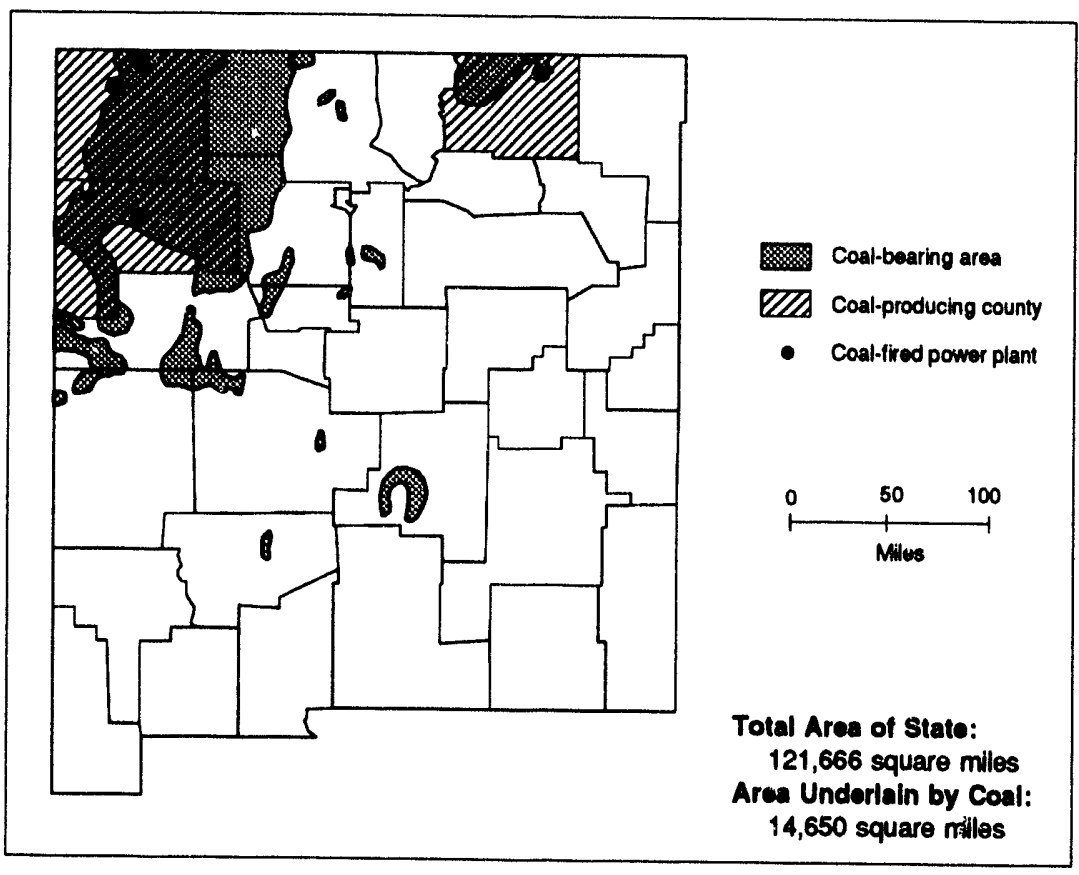

Coal Production, 1890-1992

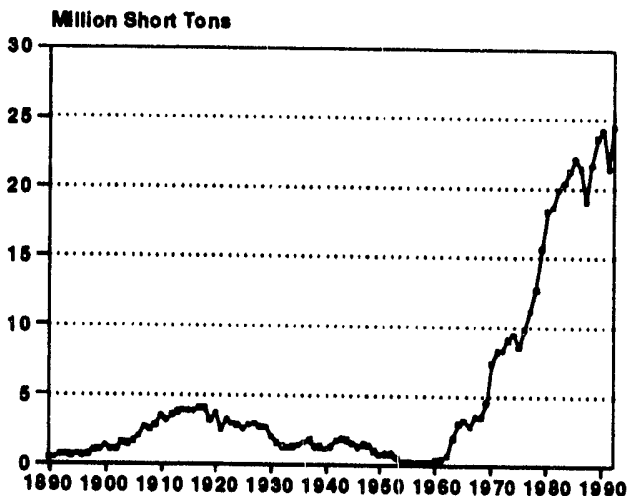

First Year of Documented Coal

Production . . . . . . . . . . . 1882 (157,000 short tons) Peak Year of Coal

Production . $1992(24,549,000$ short tons)

Coal Reserves (Million Short Tons)

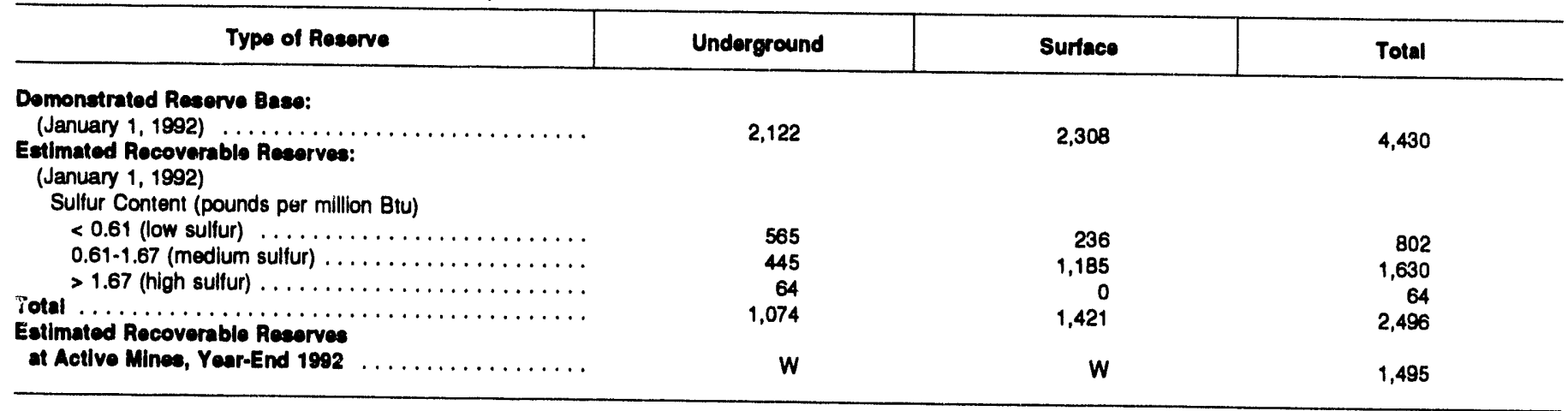

\section{Production}

\begin{tabular}{|c|c|c|c|c|c|}
\hline Salient Data by Mino Typo & 1980 & 1985 & 1980 & 1991 & 1992 \\
\hline \multicolumn{6}{|l|}{ Underground } \\
\hline Quantity (thousand short tons) $\ldots \ldots \ldots \ldots \ldots \ldots$ & 950 & 803 & 76 & 25 & 93 \\
\hline Mines $\ldots \ldots \ldots \ldots \ldots \ldots \ldots \ldots \ldots \ldots$ & 1 & 2 & 1 & 1 & 1 \\
\hline Miners $\ldots \ldots \ldots \ldots \ldots \ldots \ldots \ldots \ldots \ldots \ldots$ & 390 & 249 & 10 & 63 & 141 \\
\hline Productivity (short tons per miner per hour) $\ldots \ldots \ldots \ldots \ldots$ & 1.34 & 1.64 & 4.27 & .71 & .40 \\
\hline Average Mine Price (dollars per short ton) $\ldots \ldots \ldots \ldots \ldots$ & $w$ & W & $W$ & $w$ & W \\
\hline \multicolumn{6}{|l|}{$\begin{array}{l}\text { Surface } \\
\text { Quantity (thousand shont tons) }\end{array}$} \\
\hline Quantity (thousand short tons) $\ldots \ldots \ldots \ldots \ldots \ldots \ldots$ & 17,475 & 21,399 & 24,217 & 21,492 & 24,456 \\
\hline 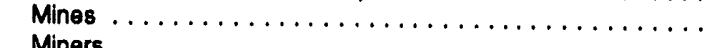 & 9 & 10 & 6 & 6 & 6 \\
\hline Miners $\ldots \ldots \ldots \ldots \ldots \ldots \ldots \ldots \ldots \ldots \ldots \ldots$ & 1,213 & 1,680 & 1,462 & 1,587 & 1,542 \\
\hline Productivity (short tons per miner per hour) $\ldots \ldots \ldots \ldots \ldots$ & 6.20 & 5.95 & 7.66 & 6.31 & 7.11 \\
\hline Average Mine Price (dollars per short ton) $\ldots \ldots \ldots \ldots \ldots$ & $w$ & $w$ & W & W & W \\
\hline \multicolumn{6}{|l|}{ Total } \\
\hline Quantity (thousand short tons) $\ldots \ldots \ldots \ldots \ldots \ldots$ & 18,425 & 22,203 & 24,292 & 21,518 & 24,549 \\
\hline 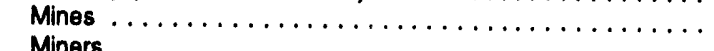 & 10 & 12 & 7 & 7 & 7 \\
\hline Miners $\ldots \ldots \ldots \ldots \ldots \ldots \ldots \ldots \ldots \ldots \ldots \ldots \ldots$ & 1,603 & 1,829 & 1,472 & 1,650 & 1,683 \\
\hline $\begin{array}{l}\text { Productivity (shon tons per miner per hour) } \ldots \ldots \ldots \ldots \ldots \\
\text { Average Mine Price (dollars per short ton) } \ldots \ldots\end{array}$ & 5.30 & 5.43 & 7.64 & 6.25 & 6.68 \\
\hline Average Mine Price (dollars per shon ton) $\ldots \ldots \ldots \ldots \ldots$ & 14.01 & 23.41 & 22.43 & 23.25 & 23.14 \\
\hline
\end{tabular}




\section{New Mexico}

Number of Mines by Production Range and Percent of Production, 1992

\begin{tabular}{|c|c|c|c|c|c|c|c|c|}
\hline \multirow{3}{*}{ Mine Type } & \multicolumn{8}{|c|}{ Production Range (thousand short tons) } \\
\hline & \multicolumn{2}{|c|}{1,000 and over } & \multicolumn{2}{|c|}{500 to 999} & \multicolumn{2}{|c|}{100 to 499} & \multicolumn{2}{|c|}{$<100$} \\
\hline & Number & Percent & Number & Percent & Number & Percent & Number & Percont \\
\hline Underground & 0 & 0 & 0 & 0 & 0 & 0 & 1 & 100 \\
\hline Surtace $\ldots \ldots \ldots \ldots \ldots \ldots \ldots \ldots \ldots$ & 5 & 97 & 1 & 3 & 0 & 0 & 0 & 0 \\
\hline All Mines $\ldots \ldots \ldots \ldots \ldots \ldots \ldots \ldots \ldots$ & 5 & 97 & 1 & 3 & 0 & 0 & 1 & $<1$ \\
\hline
\end{tabular}

Coal Demand

\begin{tabular}{|c|c|c|c|c|c|}
\hline Dlapoeltion & 1980 & 1986 & 1900 & 1991 & 1902 \\
\hline \multicolumn{6}{|l|}{ Coneumption (thousand short tons) } \\
\hline Electric Utilitios . . . . . . . . . . . . & 11,406 & 14,498 & 15,065 & 12,809 & 14,775 \\
\hline$\ldots \ldots \ldots \ldots \ldots \ldots$ & 0 & 0 & 0 & 0 & 0 \\
\hline 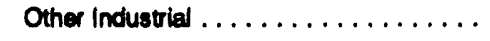 & $w$ & $w$ & w & $w$ & w \\
\hline Residential and Commercial ......... & $w$ & $w$ & $w$ & $w$ & $w$ \\
\hline Total $\ldots \ldots \ldots \ldots \ldots \ldots \ldots$ & 11,458 & 14,589 & 15,111 & 12,858 & 14,832 \\
\hline \multicolumn{6}{|l|}{ Year-End Utility Stocks } \\
\hline (thousand short tons) . & 1,429 & 1,434 & 1,538 & 1,399 & 1,570 \\
\hline \multicolumn{6}{|l|}{ Electriclity Ceneration } \\
\hline Total (million kilowatthours) $\ldots \ldots \ldots \ldots$ & 24,677 & 27,108 & 28,491 & 25,065 & 27,708 \\
\hline Coal (percent) $\ldots \ldots \ldots \ldots \ldots \ldots$ & 78 & 89 & 91 & 88 & 82 \\
\hline Nudear (percent) $\ldots \ldots \ldots \ldots \ldots$ & 0 & 0 & 0 & 0 & 0 \\
\hline Other (percent) $\ldots \ldots \ldots \ldots \ldots \ldots$ & 22 & 11 & $\boldsymbol{\theta}$ & 12 & 8 \\
\hline
\end{tabular}

\section{Utility Coal Data, 1992}

\begin{tabular}{|c|c|c|}
\hline Average Quallty and Average Deltwered Coet & Produced in State & Recelpte, All Sources \\
\hline Heat Content (million Btu per short ton) .. & 18.65 & 18.03 \\
\hline Sulfur Content (percent by woight) $\ldots \ldots \ldots \ldots \ldots \ldots \ldots \ldots$ & .69 & .81 \\
\hline Ash Content (percent by weight) $\ldots \ldots \ldots \ldots \ldots \ldots \ldots$ & 19.49 & 22.49 \\
\hline Pounds of Sultur per million Btu $\ldots \ldots \ldots \ldots \ldots \ldots \ldots \ldots$ & .74 & .90 \\
\hline Dollars per million Btu $\ldots \ldots \ldots \ldots \ldots \ldots \ldots \ldots \ldots$ & 1.46 & 1.32 \\
\hline Dollars per short ton $\ldots \ldots \ldots \ldots \ldots \ldots \ldots \ldots \ldots \ldots$ & 27.29 & 23.83 \\
\hline
\end{tabular}

Eetimated Total State Energy Consumption, 1901: 588 trillion Btu (coal, 234; natural gas, 227; petroleum, 236; nuclear electric power, 0; hydroelectrle power, 3; other, 0; net interstato flow of clectricity and ascociated losese, -112).

$W=$ Witheld to avoid disclosure of individual company data.

Notes: Totals may not equal sum of components because of independent rounding. Data coverage-Production: all mines. Number of mines: 1980, mines that produced 10,000 short tons or more; other years, all mines. Number of miners and productivity: mines that produced 10,000 or more short tons and preparation plants that had 5,000 or more employee hours. Average mine price: mines that produced 10,000 or more short tons. Average quality and average delivered coet of utlity coal: power plants with a generator nameplate capadity of 50 megawatts or more. Extent of coal-bearing areas and locations of coalconsuming plants shown on map are approximate; small coal deposits are not shown. Coal-producing counties shown on map exclude any county where all 1992 output was from mines producing less than 10,000 short tons.

Sources: Energy information Administration-U.S. Coal Reserves: An Update by Heat and Sulfur Content, February 1993; Coal Production 1992 and prior issues; Coel Data: A Reference; Quanterly Coal Report October-December 1992 and prior issues; Electric Power Annual ig91 and prior issues; Electric Power Monthly, March 1993; Cost and Quality of Fuels for Electric Power Plants 1992; Inventory of Power Plants in the United States 1992; State Energy Data Repon 1991: Consumption Estimates; Map of coal-bearing arses is based mainly on U.S. Geological Survey map, Coalfiolds of the United States, 1960. Data icr historical graph 1800-1975, U.S. Department of the Interior, Geological Survey and Bureau of Mines (Minerals Yearbook and annual predecessor Mineral Resources of the United States); 1976 tonward, Energy Information Administration, Coal Production 1992 and prior issues. 
Deetinetion of Coal Produced in New Mexico, 1992

(Million Short Tons)

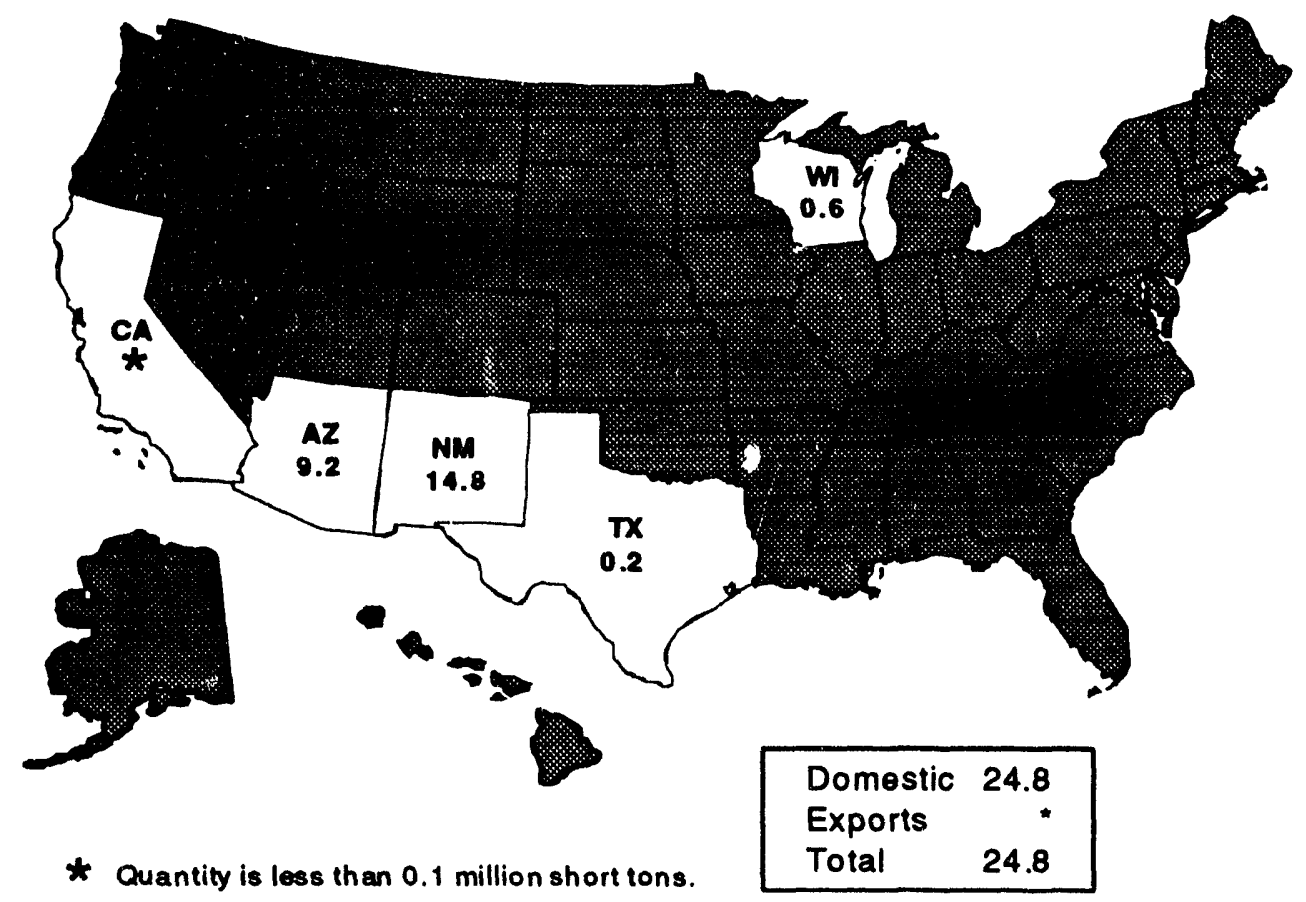

Transportation modes, domestic markets (percent): rail, 44; truck, <1; tramway/conveyor, 56; unknown, $<1$.

Note: Total may not equal sum of components because of independent rounding.

Source: Energy Information Administration, Form EIA-6, "Coai Distribution Report."

Origin of Coal Recelved in New Mexico, 1992

(Million Short Tons)

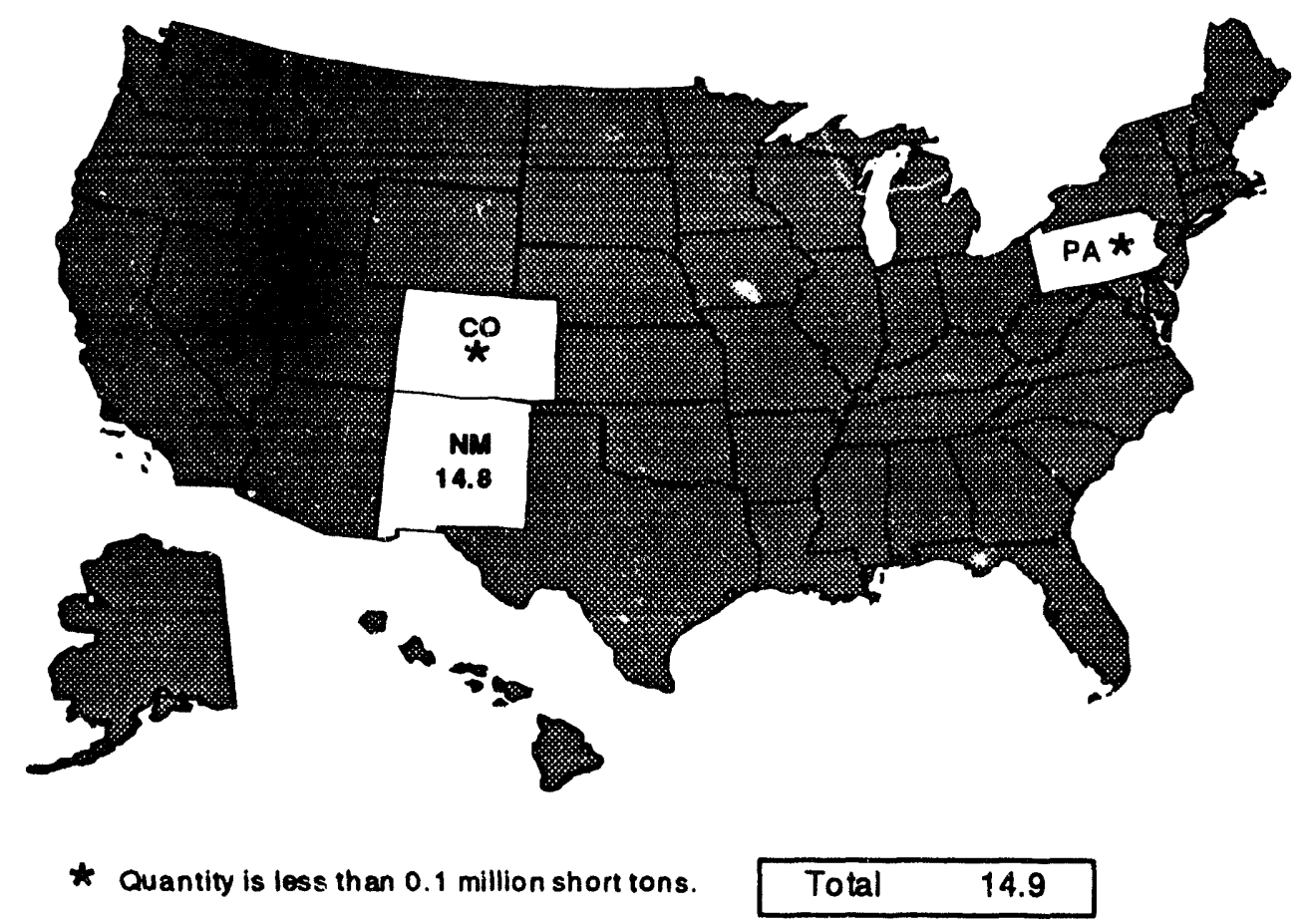

Note: Total may not equal sum of components because of independent rounding.

Source: Energy Information Administration, Form EIA-6, "Coal Distribution Report." 


\section{State Coal Profile: North Dakota}

Lignite is the only rank of coal present in North Dakota. The value of lignite produced in 1992 represented more than 20 percent of the total value of all mineral commodities produced in the State and ranked second to crude oil. Lignite output from Federal leases generated about $\$ 3$ million in royalties, disbursed to the State and the Federal Government.

Lignite deposits underlie most of the western half of North Dakota. They occur in the Williston Basin, a large depression that also extends into the adjacent States and Canada. About four lignite beds were mined in 1992, the most important of which was the BeulahZapp. This bed, which averages 14 feet in thickness, was the source for most of the State's coal output.

The first recorded use of lignite in what is now North Dakota was in 1804, when the Lewis and Clark expedition burned it in a blacksmith forge. The presence of lignite, which could be used as a fuel in the generally treeless plains of North Dakota, was one of the promotional points made by land developers, territorial officials, and railroad companies to attract settlers to the area. Commercial production began in Morton County in the early 1870 's. Production was stimulated in 1896 when State institutions were required by law to obtain as much of their fuel supply as possible from North Dakota mines.

Annual lignite production exceeded 1 million short tons in 1922, rose above 2 million short tons in the late 1930 's, and generally remained at that level into the early $1960^{\circ} \mathrm{s}$. That long period of stagnation was due largely to competition from oil and gas (some produced in the State) and to the development of hydroelectric power from the Missouri River. Production turned upward in the late 1960's chiefly to supply fuel for new electric generation plants built in the State. North Dakota was the leading lignite-producing State from about $192 n$ through 1974, when Texas gained first place. North Dakota's lignite production reached a record 32 million short tons in 1992. About 20 percent of the production was from Federal leases.

Most of the early lignite production was from underground mines. Exposed beds were usually first surface-mined with horse-drawn scrapers and hand implements, and then the bed was followed underground. Surface mining with a steam shovel began in 1919. As technology advanced, North Dakota became one of the first States to use surface mining on a large scale. Surface mines accounted for more than half of the State's coal output by the mid 1930 's and for all production since 1966. The largest coal mine in 1992, with an output of nearly 14 million short tons, was the Freedom-Coteau mine, operated by Coteau Properties Company. The mine is in Mercer County, the source of nearly half of the State's coal output.

Nearly all of the lignite produced in North Dakota is consumed in the State. Electric power plants were the principal consumers of the 30 million short tons used in 1992. The largest coal-fired generating facility is the 931-megawatt Coal Creek plant of Cooperative Power Association, McLean County. Consumption in the industrial sector is dominated by the Great Plains Synfuels Plant, the largest of the Nation's three coal gasification plants. This plant, located near Beulah and operated by Dakota Gasification Company, manufactures a high-Btu synthetic natural gas. It converts an average of 16,000 short tons of lignite per day into 142 million cubic feet of pipeline-quality gas and byproducts such as anhydrous ammonia, sulfur, and liquid nitrogen.

A small amount of coal from other States, chiefly subbituminous coal from Montana, is also used in refining sugar. Small quantities of lignite have been made into cooking briquettes. Oxidized lignite, or Leonardite, has been used as a thinner for oil well drilling mud, as an industrial water softener, and as a soil conditioner. 


\section{North Dakota}
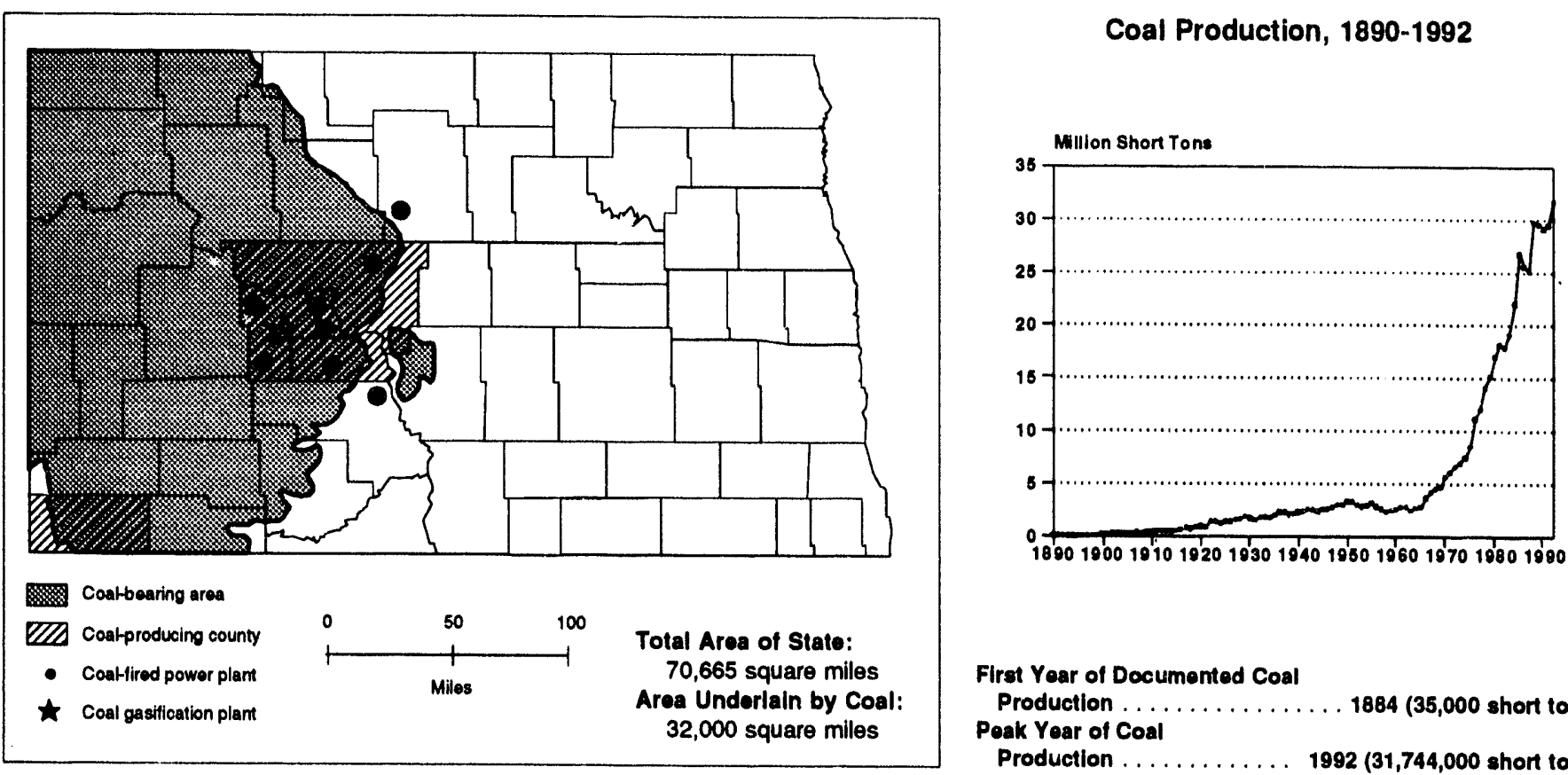

Coal Reserves (Million Short Tons)

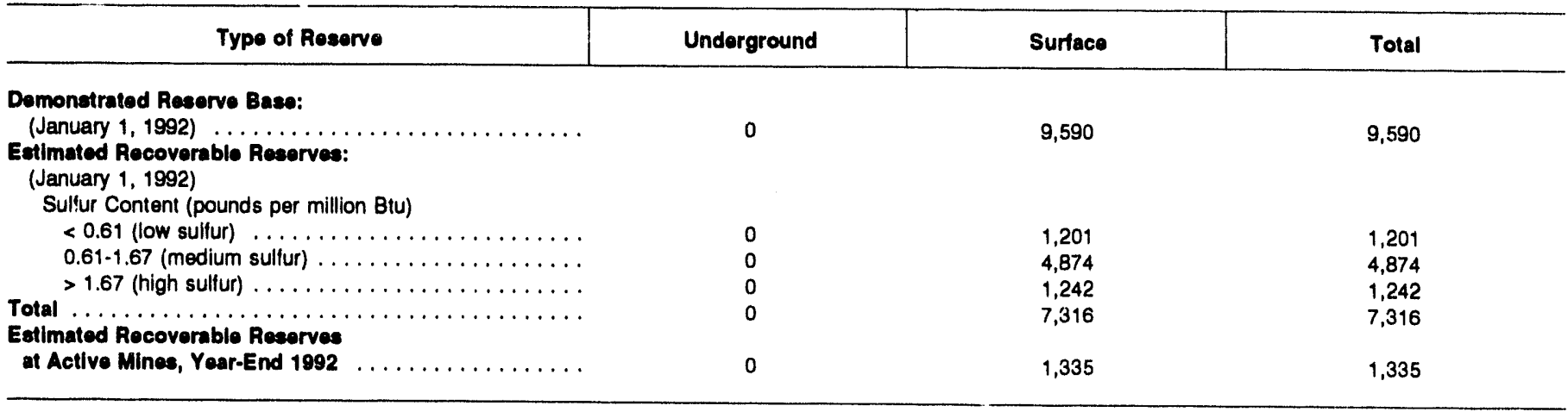

\section{Production}

\begin{tabular}{|c|c|c|c|c|c|}
\hline Sallent Data by Mino Typo & 1980 & 1985 & 1990 & 1991 & 1992 \\
\hline \multicolumn{6}{|l|}{ Underground } \\
\hline Quantity (thousand short tons) $\ldots \ldots \ldots \ldots \ldots \ldots \ldots$ & 0 & 0 & 0 & 0 & 0 \\
\hline Mines $\ldots \ldots \ldots \ldots \ldots \ldots \ldots \ldots \ldots \ldots \ldots \ldots$ & 0 & 0 & 0 & 0 & 0 \\
\hline Miners $\ldots \ldots \ldots \ldots \ldots \ldots \ldots \ldots \ldots \ldots \ldots \ldots$ & 0 & 0 & 0 & 0 & 0 \\
\hline Productivity (short tons per miner per hour) $\ldots \ldots \ldots \ldots \ldots$ & $\cdots$ & -- & $\cdots$ & -- & -- \\
\hline Average Mine Price (dollars per short ton) $\ldots \ldots \ldots \ldots \ldots$ & $-\cdot$ & $\cdots$ & 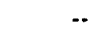 & 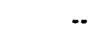 & 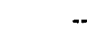 \\
\hline \multicolumn{6}{|l|}{ Surface } \\
\hline Quantity (thousand short tons) $\ldots \ldots \ldots \ldots \ldots \ldots \ldots$ & 16,975 & 26,873 & 29,213 & 29,530 & 31,744 \\
\hline Mines . . . . . . . . . . . . . . . . . . . . . & 13 & 14 & 11 & $B$ & 8 \\
\hline Miners $\ldots \ldots \ldots \ldots \ldots \ldots \ldots \ldots \ldots \ldots \ldots$ & 1,711 & 1,132 & 931 & 814 & 744 \\
\hline Productivity (short tons per miner per hour) $\ldots \ldots \ldots \ldots \ldots$ & 8.97 & 11.40 & 16.12 & 17.64 & 18.12 \\
\hline Average Mine Price (dollars per short ton) $\ldots \ldots \ldots \ldots \ldots$ & 7.48 & 9.30 & 7.67 & 7.84 & 7.48 \\
\hline \multicolumn{6}{|l|}{ Total } \\
\hline Quantity (thousand short tons) $\ldots \ldots \ldots \ldots \ldots \ldots \ldots$ & 16,975 & 26,873 & 29,213 & 29,530 & 31,744 \\
\hline Mines $\ldots \ldots \ldots \ldots \ldots \ldots \ldots \ldots \ldots \ldots \ldots \ldots$ & 13 & 14 & 11 & 8 & 8 \\
\hline Miners $\ldots \ldots \ldots \ldots \ldots \ldots \ldots \ldots \ldots \ldots \ldots$ & 1,711 & 1,132 & 931 & 814 & 744 \\
\hline Productivity (short tons per miner per hour) $\ldots \ldots \ldots \ldots$ & 8.97 & 11.40 & 16.12 & 17.64 & 18.12 \\
\hline Average Mine Price (dollars per short ton) $\ldots \ldots \ldots \ldots \ldots$ & 7.48 & 9.30 & 7.67 & 7.84 & 7.48 \\
\hline
\end{tabular}




\section{North Dakota}

\section{Number of Mines by Production Range and Percent of Production, 1992}

\begin{tabular}{|c|c|c|c|c|c|c|c|c|}
\hline \multirow{3}{*}{ Mine Typo } & \multicolumn{8}{|c|}{ Production Pange (thousand short tons) } \\
\hline & \multicolumn{2}{|c|}{1,000 and over } & \multicolumn{2}{|c|}{500 to 999} & \multicolumn{2}{|c|}{10010499} & \multicolumn{2}{|c|}{$<100$} \\
\hline & Number & Percent & Number & Percent & Number & Percent & Number & Percent \\
\hline Underground .... & 0 & 0 & 0 & 0 & 0 & 0 & 0 & 0 \\
\hline Surface $\ldots \ldots \ldots \ldots \ldots \ldots \ldots \ldots \ldots \ldots \ldots$ & 7 & 99 & 0 & 0 & 1 & 1 & 0 & 0 \\
\hline All Mines $\ldots \ldots \ldots \ldots \ldots \ldots \ldots \ldots \ldots \ldots$ & 7 & 99 & 0 & 0 & 1 & 1 & 0 & 0 \\
\hline
\end{tabular}

\section{Coal Demand}

\begin{tabular}{|c|c|c|c|c|c|}
\hline Dleposition & 1980 & 1985 & 1990 & 1991 & 1992 \\
\hline \multicolumn{6}{|l|}{ Consumption (thousand short tons) } \\
\hline Electric Utilties . . . . . . . . . . . . & 11,619 & 17,354 & 21,579 & 22,174 & 23,192 \\
\hline Coke Plants . . . . . . . . . . . . . . . & 0 & 0 & 0 & 0 & 0 \\
\hline Other Industrial . . . . . . . . . . . . & $w$ & $\mathbf{W}$ & $\mathbf{W}$ & $w$ & W \\
\hline Residential and Commerclal ........ & $\mathbf{w}$ & W & $w$ & W & $w$ \\
\hline Total $\ldots \ldots \ldots \ldots \ldots \ldots \ldots \ldots$ & 12,347 & 22,958 & 28,114 & 28,597 & 30,319 \\
\hline \multicolumn{6}{|l|}{ Year-End Utillty Stocks } \\
\hline (thousand short tons) $\ldots \ldots \ldots \ldots \ldots$ & 5,149 & 3,137 & 2,828 & 1,999 & 2,194 \\
\hline \multicolumn{6}{|l|}{ Electidelty Ceneration } \\
\hline Total (million kilowatthours) . . . . . . . . & 15,829 & 22,071 & 26,824 & 27,535 & 28,592 \\
\hline Coal (percent) $\ldots \ldots \ldots \ldots \ldots \ldots$ & 84 & 90 & 94 & 94 & 94 \\
\hline Nuclear (percent) $\ldots \ldots \ldots \ldots \ldots \ldots$ & 0 & 0 & 0 & 0 & 0 \\
\hline Other (percent) $\ldots \ldots \ldots \ldots \ldots \ldots$ & 16 & 10 & 6 & 6 & 6 \\
\hline
\end{tabular}

\section{Utilly Coal Deta, 1992}

\begin{tabular}{|c|c|c|}
\hline Avernge Qually and Averace Dellvered Coat & Produced in State & Rocolpts, All Sources \\
\hline Heat Content (million Btu per short ton) $\ldots \ldots \ldots \ldots \ldots \ldots \ldots$ & 13.03 & 13.12 \\
\hline Sulfur Content (percent by weight) $\ldots \ldots \ldots \ldots \ldots \ldots \ldots \ldots$ & .87 & .87 \\
\hline Ash Content (percent by weight) $\ldots \ldots \ldots \ldots \ldots \ldots \ldots$ & 9.30 & 9.29 \\
\hline Pounds of Sultur per million Btu $\ldots \ldots \ldots \ldots \ldots \ldots \ldots \ldots$ & 1.34 & 1.33 \\
\hline Dollars per million Btu $\ldots \ldots \ldots \ldots \ldots \ldots \ldots \ldots \ldots$ & .75 & .72 \\
\hline Dollars per short ton $\ldots \ldots \ldots \ldots \ldots \ldots \ldots \ldots \ldots \ldots$ & 9.81 & 9.45 \\
\hline
\end{tabular}

Eetimated Total Stato Energy Consumption, 1901: 320 trillion Btu (coal, 379; natural gas, 42; petroleum, 114; nuclear electric power, 0; hydroelectric power, 23; other, 0; net interatate flow of electricity and seseclated losese, -238).

$W=$ Withheld to avoid disclosure of individual company data.

Notes: Totale may not equal sum of components because of independent rounding. Data coverage-Production: all mines. Number of mines: 1980 , mines that produced 10,000 short tons or more; other years, all mines. Number of minere and productivity: mines that produced 10,000 or more short tons and preparation plants that had 5,000 or more employee hours. Average mine price: mines that produced 10,000 or more short tons. Average quality and average delivered cost of utility coal: power plants with a generator nameplate capacity of 50 megawatts or more. Extent of coal-bearing areas and locations of coalconsuming plants shown on map are approximate; small coal deposits are not shown. Coal-producing counties shown on map exclude any county where all 1992 output was from mines producing less than 10,000 short tons.

Sources: Energy Information Administration-U.S. Coal Reserves: An Update by Heat and Sulfur Content, February 1993 ; Coal Production 1992 and prior issues; Coal Data: A Reference; Quantenty Coal Report October-December 1992 and prior issues; Electric Power Annual 1991 and prior issues; Electric Power Monthly, March 1993; Cost and Quality of Fuels for Electric Power Plants 1992; Inventory of Power Plants in the United States 1992; State Energy Data Report 1991: Consumption Estimates; Map of coal-bearing areas is based mainly on U.S. Geological Survey map, Coalfields of the United States, 1960. Data for historical graph 1890-1975, U.S. Department of the Interior, Geological Survey and Bureau of Mines (Minerals Yearbook and annual predecessor Mineral Resources of the United States); 1976 forward, Energy Information Administration, Coal Production 1992 and prior issues. 
Deotination of Coal Produced in North Dakota, 1992

(Million Short Tons)

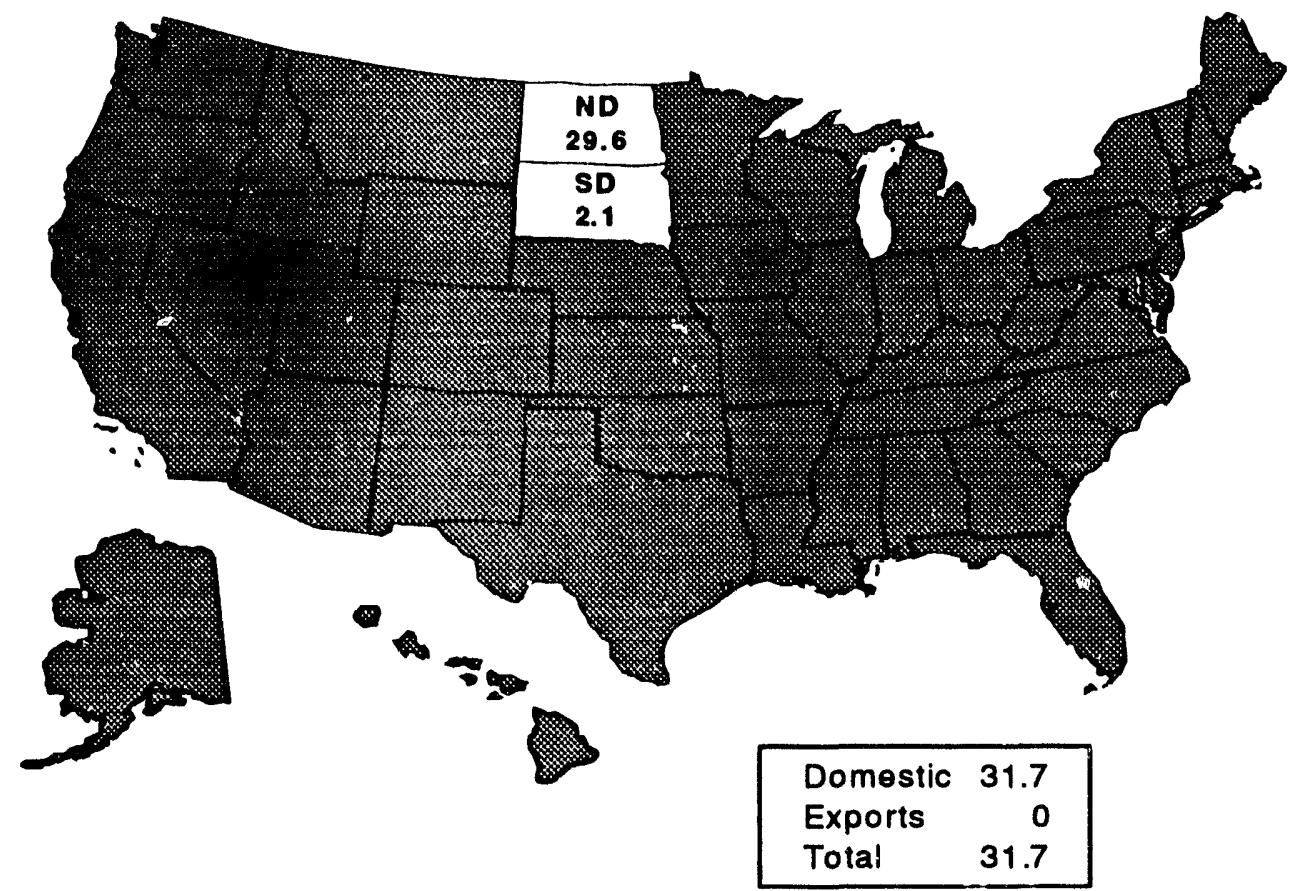

Transportation modes, domestic markets (percent): rail, 9; truck, 14; tramway/conveyor, 77; unknown, $<1$.

Note: Total may not equal sum of components because of independent rounding.

Source: Energy Information Administration, Form EIA-6, "Coal Distribution Report."

\section{Origin of Coal Recelved in North Dakota, 1992}

(Million Short Tons)

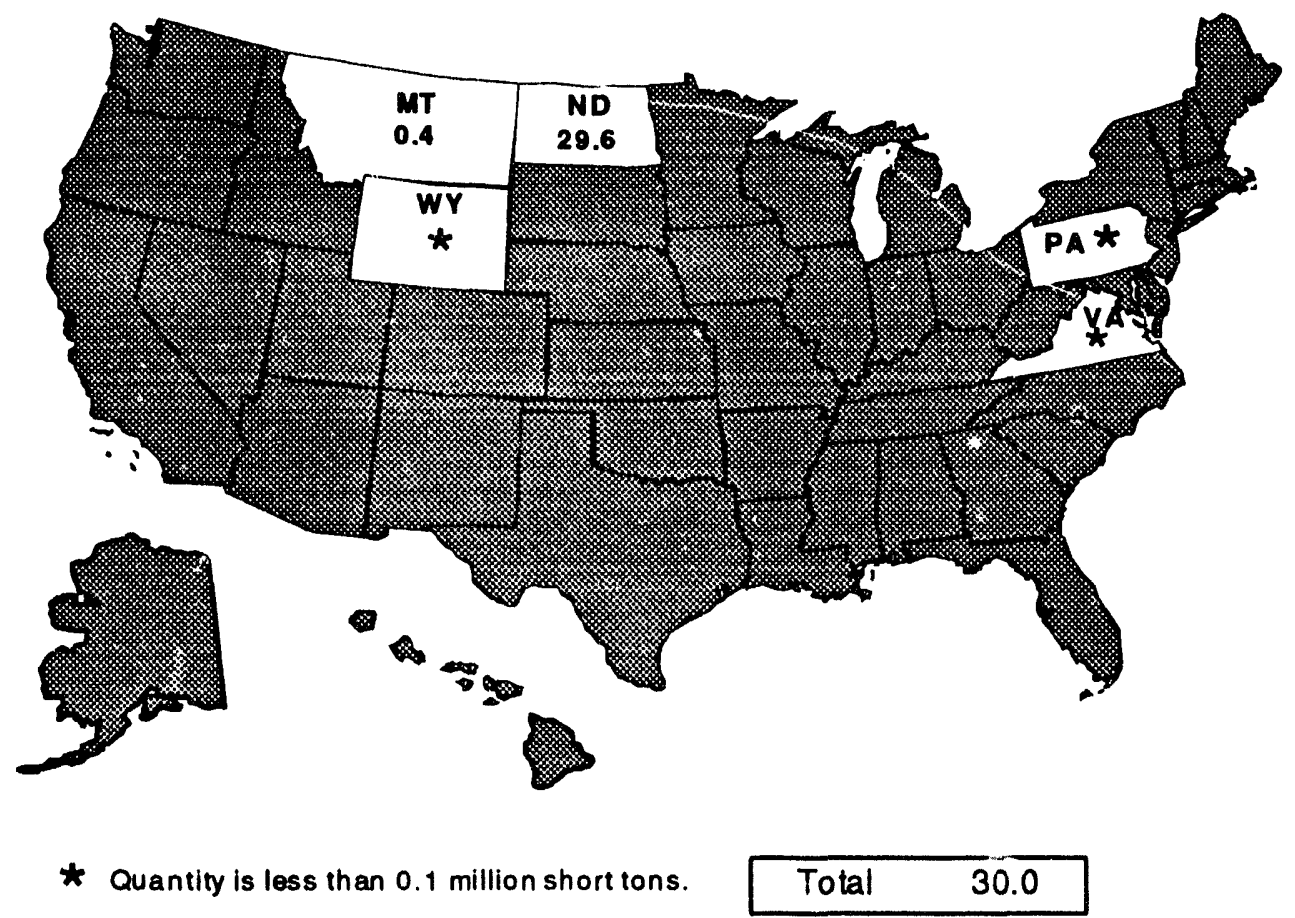

Note: Total may not equal sum of components because of independent rounding.

Source: Energy Information Administration, Form EIA-6, "Coal Distribution Report." 


\section{State Coal Profile: Ohio}

Coal is the most valuable mineral commodity in Ohio. Coal production in 1992 was estimated to account for about $\mathbf{4 0}$ percent of the total value of all mineral commodities produced in the State, including crude oil and natural gas.

The coal reserves of Ohio are part of the Appalachian coal basin and consist entirely of bituminous coal. The deposits underlie the eastern part of the State. As mined, the coal has a heat value ranging from 22 to 25 million Btu per short ton, but its use has been hampered by a high sulfur content, averaging more than 3 percent by weight. About 20 coalbeds were mined in 1992, but more than half of the output was from the Pittsburgh, Sewickley/Meigs, and Clarion coalbeds.

Coal production in Ohio began in the 1800 's. Its early use expanded from domestic heating to blacksmithing, brickmaking, and evaporating brine in the salt industry. In 1827, flatboats carried the first shipments of coal to Cleveland via the Ohio-Erie Canal for use in steamboats. As early as 1835, coal was shipped down the Ohio and Mississippi Rivers for use in sugar refineries in New Orleans. By 1875, when more markets were opened due to the canal systems and railroad expansions across the State, Ohio's coal output rose to more than 5 million short tons. The presence of coal suitable for use in blast furnaces plus the occurrence of iron ore and limestone spurred the development of the coal industry and the iron and steel industry in the State.

By the end of World War I in 1918, coal production reached 46 million short tons. Subsequent production declined, due partly to the Depression and partly to the greater use of oil and natural gas. World War II gave an impetus to the State's coal industry, and production gradually rose to an all-time high of 55 million short tons in 1970. Since then, the demand for Ohio's coal, which is handicapped by a high sulfur content, has been adversely affected by the enactment of clean air legislation and production has trended downward. Production was 30 million short tons in 1992.
Underground mining was the chief source of Ohio's coal production until World War II. Surface mining, which began in Ohio in 1915, now accounts for more than half of the State's coal production. However, the largest coal mine in Ohio in 1992, producing more than 3 million short tons, was the Powhatan No. 6 underground mine of the Ohio Valley Coal Company, in Belmont County. The State's leading coal-producing counties were Belmont and Meigs.

About 90 percent of the coal shipped from Ohio's mines in 1992 was delivered to consumers in the State, mainly electric utilities. A small amount was exported. Ohio coal represented nearly half of the total coal shipments to consumers in the State, with most of the balance from West Virginia and Kentucky. In 1992, Ohio was the third-largest coal-consuming State, following Texas and Indiana. Electric utilities were by far the largest markat for the 59 million short tons of coal consumed in Ohio. About half of the utility coal used was produced in the State; the balance was mostly from West Virginia anc Kentucky. In 1992, Ohio's power plants led the Nation in the amount of electricity generated from coal. Ohio's largest coal-fired electric utility is the 2,600-megawait General James M. Gavin plant of Ohio Power Company, in Gallia County. More than half of the coal for Ohio's coke plants was from West Virginia, and the rest was from Kentucky and Virginia. Foremost among the many other industrial coal consumers in Ohio were paper mills and manufacturers of electrometallurgical products and industrial organic chemicals. More than 40 percent of this coal was from Ohio, with the balance mostly from Kentucky.

The Cleveland Customs District was the third-largest coal-exporting district in 1992, handling 10 million short tons, or 10 percent of the Nation's coal exports. Coal terminals are at Ashtabula, Conneaut, Sandusky, and Toledo. Most of the coal shipments from these terminals are to Canada. 


\section{Ohio}
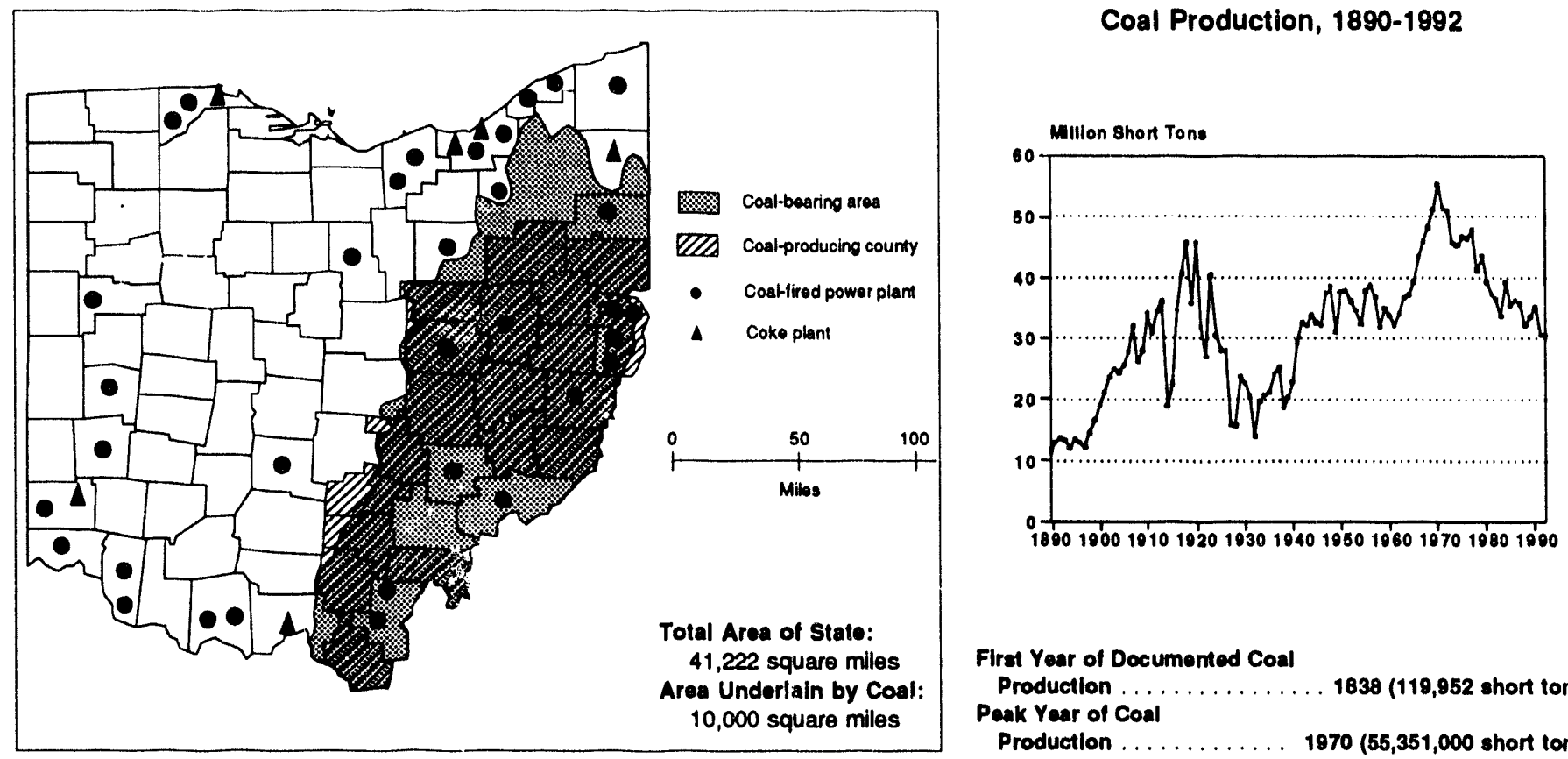

Coal Reserves (Million Short Tons)

\begin{tabular}{|c|c|c|c|}
\hline Type of Reserve & Underground & Surface & Total \\
\hline \multicolumn{4}{|l|}{ Demonstrated Reserve Base: } \\
\hline \multicolumn{4}{|l|}{$\begin{array}{l}\text { Estimated Rocoverable Resorves: } \\
\text { (January 1, 1992) }\end{array}$} \\
\hline$<0.61$ (low sulfur) $\ldots \ldots \ldots \ldots$ & 135 & 118 & 253 \\
\hline $0.61 \cdot 1.67$ (medium sultur) $\ldots \ldots \ldots \ldots \ldots \ldots \ldots$ & 804 & 590 & 1,394 \\
\hline at Active Mines, Year-End $1992 \ldots \ldots \ldots \ldots \ldots$ & 316 & 260 & 576 \\
\hline
\end{tabular}

\section{Production}

\begin{tabular}{|c|c|c|c|c|c|}
\hline Salient Data by Mine Type & 1980 & 1985 & 1990 & 1991 & 1992 \\
\hline \multicolumn{6}{|l|}{ Underground } \\
\hline Quantity (thousand short tons) $\ldots \ldots \ldots \ldots \ldots \ldots$ & 12,994 & 13,646 & 12,920 & 12,237 & 12.031 \\
\hline Mines $\ldots \ldots \ldots \ldots \ldots \ldots \ldots \ldots \ldots \ldots \ldots$ & 19 & 14 & 13 & 12 & 10 \\
\hline 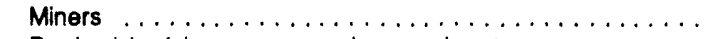 & 7,843 & 4,166 & 2,603 & 2,359 & 1,926 \\
\hline Productivity (short tons per miner per hour) . . . . . . . . . & .93 & 1.66 & 2.34 & 2.55 & 3.01 \\
\hline Average Mine Price (dollars per short ton) $\ldots \ldots \ldots \ldots \ldots$ & 38.42 & 41.75 & 33.93 & 31.52 & 30.11 \\
\hline \multicolumn{6}{|l|}{ Suriace } \\
\hline Quantity (thousand short tons) $\ldots \ldots \ldots \ldots \ldots \ldots \ldots$ & 26,400 & 21,956 & 22,332 & 18,333 & 18,371 \\
\hline 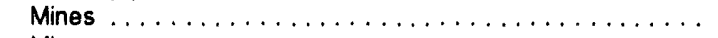 & 180 & 190 & 159 & 147 & 139 \\
\hline 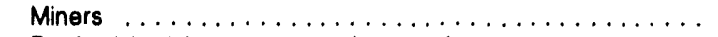 & 6,795 & 4,788 & 3,263 & 2,934 & 2,589 \\
\hline Productivity (short tons per miner per hour) $\ldots \ldots \ldots \ldots \ldots$ & 2.03 & 2.34 & 3.17 & 2.76 & 3.06 \\
\hline Average Mine Price (dollars per short ton) $\ldots \ldots \ldots \ldots \ldots$ & 22.60 & 29.11 & 25.57 & 25.22 & 24.84 \\
\hline \multicolumn{6}{|l|}{ Total } \\
\hline Quantity (thousand short tons) $\ldots \ldots \ldots \ldots \ldots \ldots$ & 39,394 & 35,602 & 35,252 & 30,569 & 30,403 \\
\hline 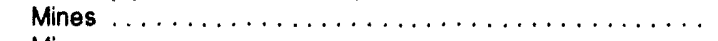 & 199 & 204 & 172 & 159 & 149 \\
\hline 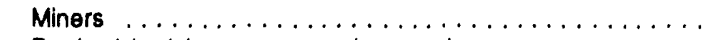 & 14,638 & 8,954 & 5,866 & 5,293 & 4,515 \\
\hline Productivity (shon tons per miner per hour) $\ldots \ldots \ldots \ldots \ldots$ & 1.46 & 2.02 & 2.80 & 2.67 & 3.04 \\
\hline Average Mine Price (dollars per short ton) $\ldots \ldots \ldots \ldots \ldots$ & 27.82 & 33.97 & 28.65 & 27.75 & 26.93 \\
\hline
\end{tabular}




\section{Ohio}

Number of Mines by Production Range and Percent of Production, 1992

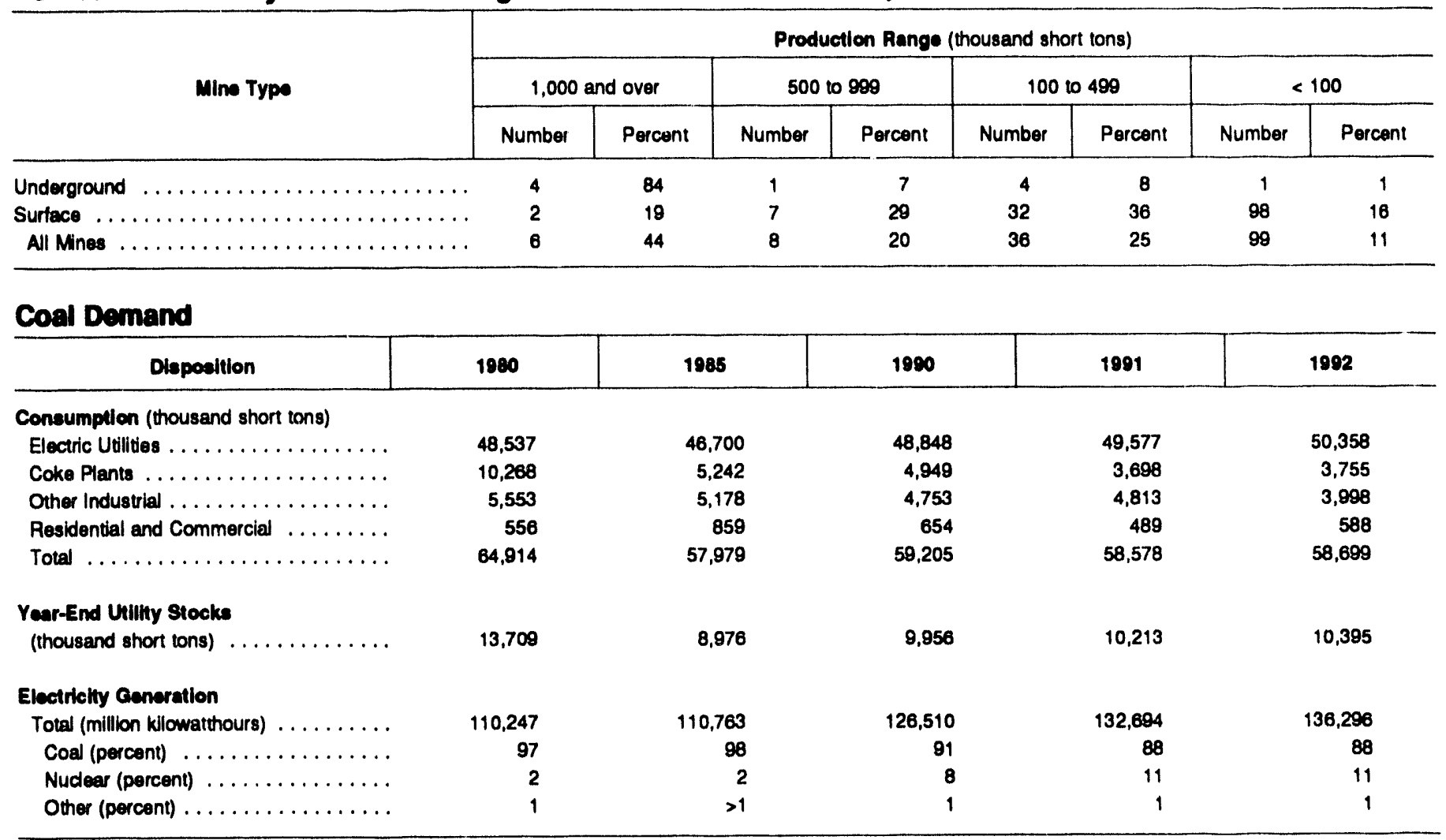

Utility Coal Data, 1992

\begin{tabular}{|c|c|c|}
\hline Average Quallty and Average Deltvered Cost & Produced In State & Recelpts, All Sources \\
\hline Heat Content (million Btu per short ton) $\ldots \ldots \ldots \ldots$ & 23.70 & 23.97 \\
\hline Sulfur Content (percent by weight) $\ldots \ldots \ldots \ldots \ldots \ldots \ldots \ldots$ & 3.42 & 2.57 \\
\hline Ash Content (percent by weight) $\ldots \ldots \ldots \ldots \ldots \ldots \ldots \ldots$ & 10.98 & 11.24 \\
\hline Pounds of Sultur per million Btu $\ldots \ldots \ldots \ldots \ldots \ldots \ldots \ldots$ & 2.89 & 2.14 \\
\hline Dollars per million Btu $\ldots \ldots \ldots \ldots \ldots \ldots \ldots \ldots \ldots \ldots$ & 1.41 & 1.44 \\
\hline Dollars per short ton $\ldots \ldots \ldots \ldots \ldots \ldots \ldots \ldots \ldots$ & 33.32 & 34.40 \\
\hline
\end{tabular}

Estimated Totel State Energy Consumption, 1991: 3,687 trillion Btu (coal, 1,413; natural gas, 799; potroleum, 1,090; nuclear electric powor, 159; hydroclectic power, 2; other, 3; net interetate flow of electricity and aseoclated losese, 221).

Notes: Totals may not equal sum of components because of independent rounding. Date coverage-production: all mines. Number of mines: 1980 , mines that produced 10,000 short tons or more; other years, all mines. Number of miners and productivity: mines that produced 10,000 or more short tons and preparation plants that had 5,000 or more employee hours. Average mine price: mines that produced 10,000 or more short tons. Average quality and average dellvered coet of utility coal: power plants with a generator nameplate capacity of 50 megawatts or more. Extent of coal-bearing areas and locations of coalconsuming plents shown on map are approximate; small coal deposits are not shown. Coal-producing counties shown on map exclude any county where all 1992 output was from mines producing less than 10,000 short tons.

Sources: Energy Information Administration-U.S. Coal Reserves: An Update by Heat and Sulfur Content, February 1993; Coal Production 1992 and prior issues; Coal Data: A Reference; Quartenty Coal Report October-December 1992 and prior issues; Electric Power Annual 1991 and prior issues; Electric Power Monthly, March 1993; Cost and Quality of Fuels for Electric Power Plants 1992; Inventory of Power Plants in the United States 1992; State Energy Data Report 1991: Consumption Estimates; Map of coal-bearing areas is based mainly on U.S. Geological Survey map, Coalfields of the United States, 1960. Data for historical graph 1890-1975, U.S. Department of the Interior, Geological Survey and Bureau of Mines (Minerals Yearbook and annual predecessor Mineral Resources of the United States); 1976 forward, Energy Information Administration, Coal Production 1992 and prior issues. 
Doetinetion of Coal Produced in Ohio, 1992

(Million Short Tons)

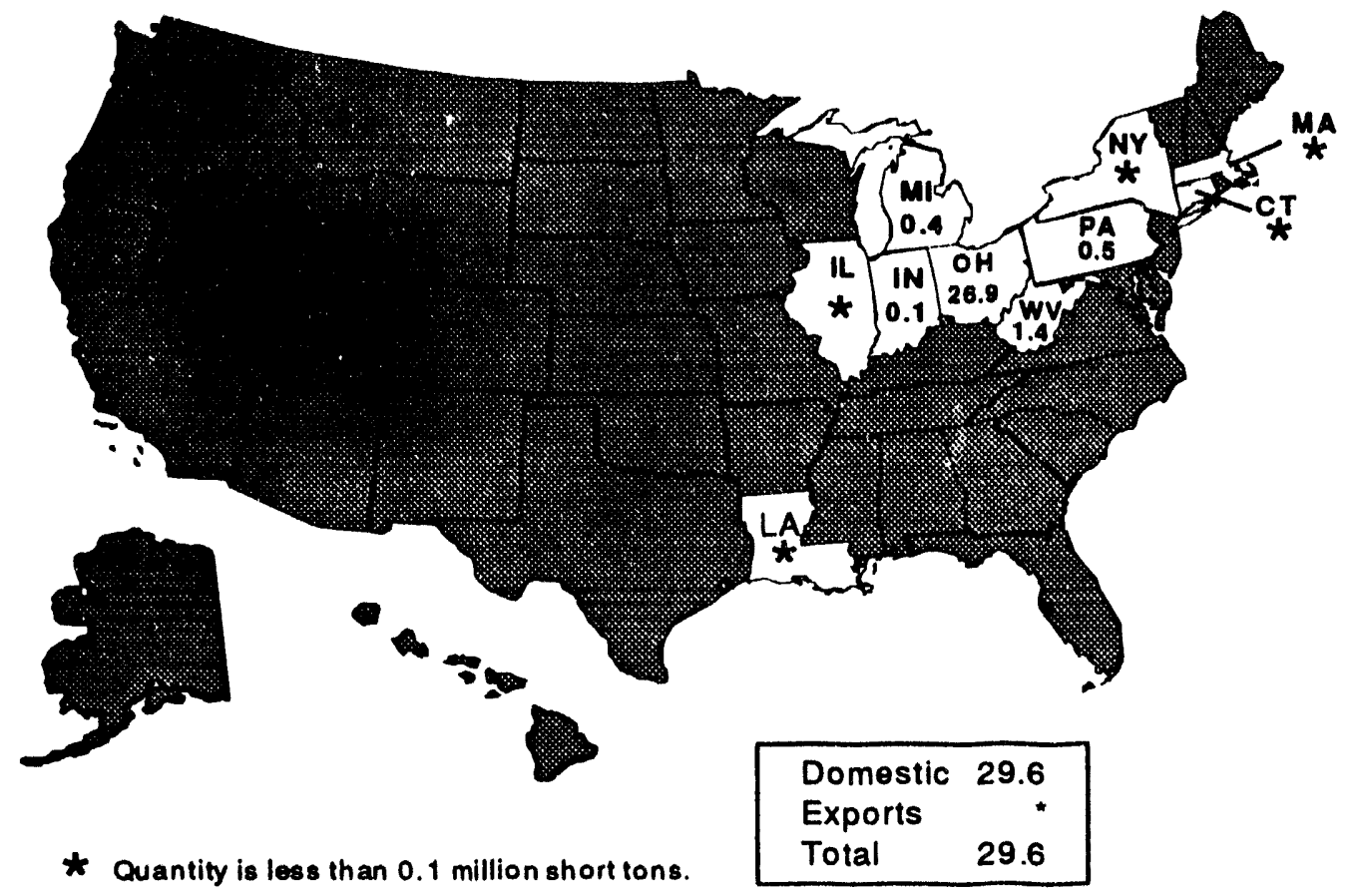

Transportation modes, domestic markets (percent): rail, 7; water, 25; truck, 40; tramway/conveyor, 27; unknown, $<1$.

Note: Total may not equal sum of components because of independent rounding.

Source: Energy Information Adrninistration, Form EIA-6, "Coal Distribution Report."

\section{Origin of Coal Recelved in Ohlo, 1992}

(Million Short Tons)

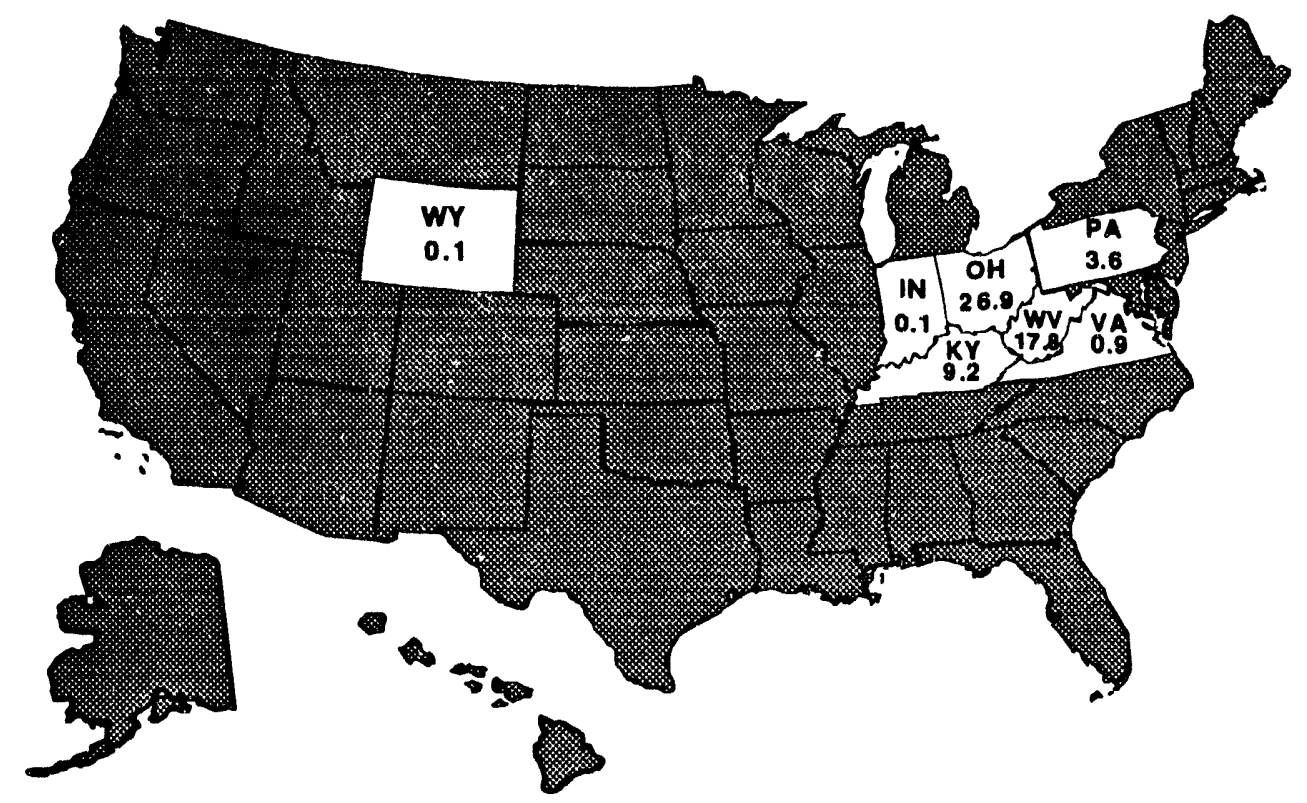

Note: Total may not equal sum of components because of independent rounding.

Source: Energy Information Administration, Form EIA-6, "Coal Distribution Report." 


\section{State Coal Profile: Oklahoma}

In 1992 the coal industry in Oklahoma was small. The value of the 2 million short tons produced represented about 1 percent of the estimated value of all mineral commodities produced, including crude oil and natural gas. Coal production from Federal leases generated less than $\$ 0.5$ million in royalties, which were shared by the State and the Federal Government.

Oklahoma's economic coal deposits, all bituminous in rank, are in the eastern part of the State. Of the nine coalbeds mined in 1992, the Secor was the leading source of production in 1992. The thickness of the beds mined range from 1 to 3 feet. The heat content of the coal produced averages about 25 million Btu per short ton, and the sulfur content is high, averaging about 3 percent by weight. The coal in some beds has been used to produce coke for the iron and steel industry, but none is currently mined for this purpose.

Coal, reportedly, was first used in Oklahoma in the early 1800 's by local Indians, who dug it by hand and sold it by the basket. Commercial production began in 1872 with the construction of the Missouri-Kansas-Texas Railroad. From the beginning of the 1900's through World War I, coal was a major fuel in the State. Coal production reached about 5 million short tons in 1920, but then fell, due to the Depression and competition with oil from fields discovered in the State. After rising to meet the demand for coal during World War II, Oklahoma's annual coal output fell below 1 million short tons around the mid-1960's. The demand for the State's coal rose as the result of the Arab oil embargo in 1973, and production reached an all-time record of 6 million short tons in 1978. Since then, however, output has fallen, reflecting a lower demand for the highsulfur coal produced in the State. Oklahoma's coal production was less than 2 million short tons in 1992.

Early production of coal in Oklahoma was almost entirely from underground mines. With the development of large equipment, surface mining became increasingly important and accounted for about half of the annual production in the 1940's and for more than 90 percent in later years. Le Flore, Haskell, and Latimer counties were the leading sources of production in 1992. Latimer County's Red Oak surface mine, operated by Farrell-Cooper Mining Company, was the leading producer. Nearly one-third of Oklahoma's coal output in 1992 was from Federal leases.

The bulk of the coal produced in Oklahoma is consumed in the State, mostly to produce electricity. Electric utilities in Oklahoma are required by State law to blend at least 10 percent Oklahoma coal with coal used from other sources, based on heat value. Electric utilities are by far the largest coal consumers in the State, accounting for more than 90 percent of the 17 million short tons used in 1992. Most of the utility coal used was low-sulfur subbituminous coal from Wyoming. Oklahoma's largest coal-fired generating units, totaling 1,515 megawatts, are at the Muskogee plant of Oklahoma Gas and Electric Company, in Muskogee County. Small amounts of coal were also consumed in other industries, such as paper mills and cement plants. 


\section{Oklahoma}

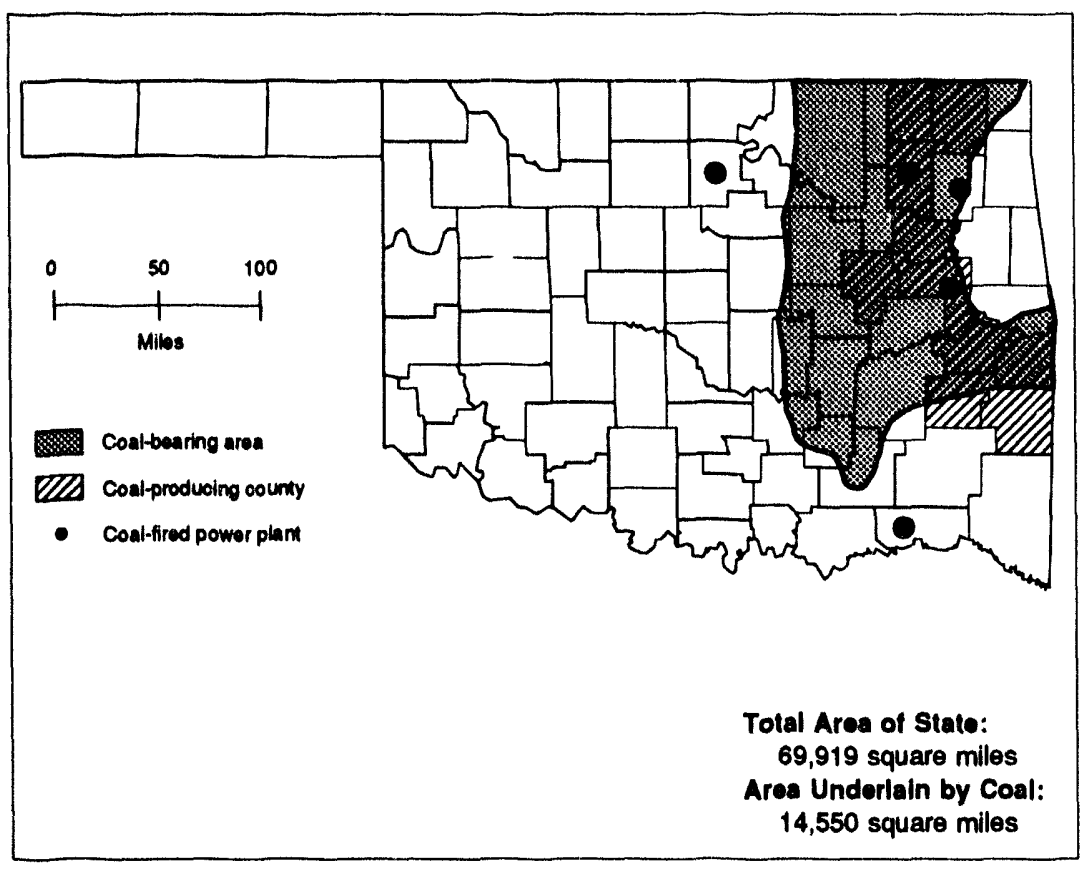

Coal Production, 1890-1992

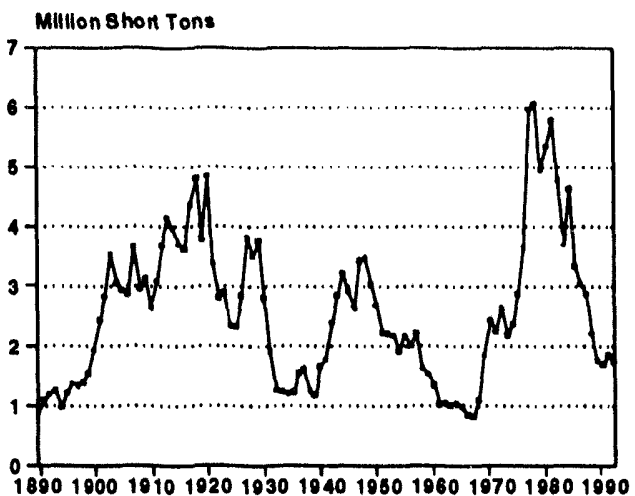

First Year of Documented Coal

Production . . . . . . . . . . 1880 (120,947 short tons) Peak Yoar of Coal

Production . $1978(6,070,000$ short tons)

\section{Coal Reserves (Million Short Tons)}

\begin{tabular}{|c|c|c|c|}
\hline Typo of Rosorve & Undorground & Surface & Total \\
\hline \multicolumn{4}{|l|}{ Demonetrated Raserve Base: } \\
\hline (January 1,1992$) \ldots \ldots$. & 1,238 & 349 & 1,587 \\
\hline$<0.61$ (low sulfur) $\ldots \ldots \ldots \ldots$ & 154 & 67 & 222 \\
\hline $0.61-1.67$ (medium sulfur) $\ldots \ldots \ldots$ & 243 & 60 & 302 \\
\hline $\begin{array}{l}\text { Estimated Recoverable Reservee } \\
\text { at Active Mines, Year-End } 1992 \text {. }\end{array}$ & W & w & 48 \\
\hline
\end{tabular}

\section{Production}

\begin{tabular}{|c|c|c|c|c|c|}
\hline Salient Data by Mine Type & 1980 & 1985 & 1990 & 1991 & 1992 \\
\hline \multicolumn{6}{|l|}{ Underground } \\
\hline Quantity (thousand short tons) $\ldots \ldots \ldots \ldots \ldots \ldots$ & 0 & 5 & 105 & 26 & 59 \\
\hline 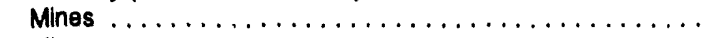 & 0 & 1 & 1 & 1 & 1 \\
\hline Miners $\ldots \ldots \ldots \ldots \ldots \ldots \ldots \ldots \ldots \ldots \ldots$ & 0 & NA & 36 & 31 & 24 \\
\hline Productivity (short tons per miner per hour) . . . . . . . . . & -- & NA & 1.30 & .52 & 1.04 \\
\hline Average Mine Price (doliars per short ton) $\ldots \ldots \ldots \ldots \ldots$ & 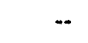 & NA & W & $\bar{W}$ & W \\
\hline \multicolumn{6}{|l|}{ Surface } \\
\hline Quantity (thousand short tons) $\ldots \ldots \ldots \ldots \ldots \ldots \ldots$ & 5,358 & 3,332 & 1,593 & 1,815 & 1,683 \\
\hline Mines $\ldots \ldots \ldots \ldots \ldots \ldots \ldots \ldots \ldots \ldots$ & 37 & 27 & 22 & 21 & 19 \\
\hline Miners $\ldots \ldots \ldots \ldots \ldots \ldots \ldots \ldots \ldots \ldots \ldots$ & 1,340 & 1,024 & 379 & 379 & 310 \\
\hline Productivity (short tons per miner per hour) . . . . . . . . . & 1.68 & 1.74 & 2.17 & 2.42 & 2.26 \\
\hline Average Mine Price (dollars per short ton) $\ldots \ldots \ldots \ldots \ldots$ & 27.78 & 31.72 & W & W & W \\
\hline \multicolumn{6}{|l|}{ Total } \\
\hline Quantity (thousand short tons) $\ldots \ldots \ldots \ldots \ldots \ldots$ & 5,358 & 3,337 & 1,698 & 1,841 & 1,741 \\
\hline Mines $\ldots \ldots \ldots \ldots \ldots \ldots \ldots \ldots \ldots \ldots \ldots \ldots$ & 37 & 28 & 23 & 22 & 20 \\
\hline Miners $\ldots \ldots \ldots \ldots \ldots \ldots \ldots \ldots \ldots \ldots \ldots \ldots$ & 1,340 & 1,024 & 415 & 410 & 334 \\
\hline Productivity (short tons per miner per hour) . . . . . . . . . & 1.68 & 1.74 & 2.08 & 2.30 & 2.17 \\
\hline Average Mine Price (dollars per short ton) . . . . . . . . . & 27.78 & 31.72 & 30.39 & 28.52 & 25.76 \\
\hline
\end{tabular}




\section{Oklahoma}

Number of Mines by Production Range and Percent of Production, 1992

\begin{tabular}{|c|c|c|c|c|c|c|c|c|}
\hline \multirow{3}{*}{ Mins Type } & \multicolumn{8}{|c|}{ Production Range (thousand short tons) } \\
\hline & \multicolumn{2}{|c|}{1,000 and over } & \multicolumn{2}{|c|}{500 to 999} & \multicolumn{2}{|c|}{100 to 499} & \multicolumn{2}{|c|}{$<100$} \\
\hline & Number & Percent & Number & Percent & Number & Percent & Number & Percent \\
\hline Underground $\ldots$. & 0 & 0 & 0 & 0 & 0 & 0 & 1 & 100 \\
\hline Surtace $\ldots \ldots \ldots \ldots \ldots \ldots \ldots \ldots \ldots \ldots \ldots \ldots$ & 0 & 0 & 0 & 0 & 6 & 68 & 13 & 32 \\
\hline All Mines $\ldots \ldots \ldots \ldots \ldots \ldots \ldots \ldots \ldots$ & 0 & 0 & 0 & 0 & 6 & 65 & 14 & 35 \\
\hline
\end{tabular}

\section{Coal Demand}

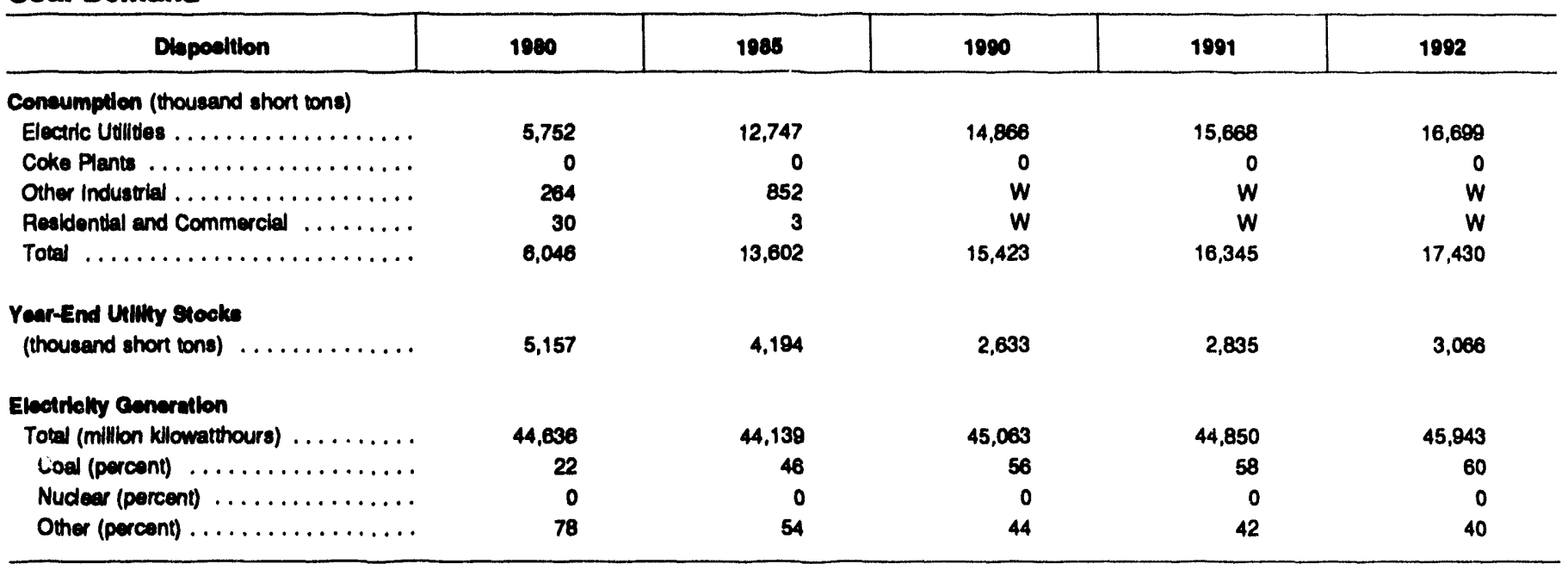

\section{Utilty Coal Data, 1992}

\begin{tabular}{|c|c|c|}
\hline Averege Cuality and Avernge Deltwered Cost & Produced In State & Recolpts, All Sources \\
\hline Heat Content (million Btu per short ton) . . . . . & 24.97 & 17.40 \\
\hline Sulfur Content (percent by woight) $\ldots \ldots \ldots \ldots \ldots \ldots \ldots$ & 2.78 & .42 \\
\hline Ash Content (percent by woight) $\ldots \ldots \ldots \ldots \ldots \ldots \ldots \ldots$ & 9.77 & 5.24 \\
\hline Pounds of Sultur per million Btw $\ldots \ldots \ldots \ldots \ldots \ldots \ldots \ldots$ & 2.23 & .48 \\
\hline Dollars per million Btu $\ldots \ldots \ldots \ldots \ldots \ldots \ldots \ldots \ldots \ldots$ & 1.17 & 1.23 \\
\hline Dollars per short ton $\ldots \ldots \ldots \ldots \ldots \ldots \ldots \ldots \ldots \ldots$ & 29.27 & 21.47 \\
\hline
\end{tabular}

Estimated Tetal stato Energy Ceneumpllen, 1991: 1,283 tillion Btu (coal, 292; natural gas, 582; petroleum, 432; nuclear electric power, 0; hydroelectric power, 19; cther, 0; net interstate flow of clocticlty and ascoclated losess, -42).

W - Withineld to avoid disclosure of individual company data.

NA = Not avallable.

Notes: Totels may not equal sum of components because of independent rounding. Data coverage-Production: all mines. Number of mines: 1880 . mines that produced 10,000 short tons or more; other years, all mines. Number of miners and productivity: mines that produced 10,000 or more short tons and preparation plants that had 5,000 or more employee hours. Average mine prles: mines that produced 10,000 or more short tons. Average quallty and average dellvered coet of utlity coal: power plants with a generator nameplate capacity of 50 megawatts or more. Extent of coal-bearing areas and locations of coalconsuming plants shown on map are approximate; small coal deposits are not shown. Coal-producing counties shown on map exclude any county where all 1992 output was from mines producing less than 10,000 short tons.

Sources: Energy Information Administration-U.S. Coal Reserves: An Update by Heat and Sulfur Content, Fobruary 1993 ; Coal Production 1992 and prior issues; Cosl Data: A Relerence; Quanterly Coal Report October-December 1992 and prior issues; Electric Power Annual 1991 and prior issues; Electric Power Monthly, March 1893; Cost and Qually of Fuels for Electric Power Plants 1992; Inventory of Power Plants in the United States 1992; State Energy Data Report 1991: Consumption Estimates; Map of coal-bearing areas is based mainly on U.S. Geological Survey map, Coalfields of the United States, 1960. Data for historical graph 1890-1975, U.S. Department of the Interior, Geological Survey and Bureau of Mines (Minerals Yearbook and annual predecessor Mineral Resources of the United States); 1976 fonward, Energy Information Administration, Coal Production 1992 and prior issues. 
Dostinetlon of Coal Produced in Oklahoma, 1992

(Million Short Tons)

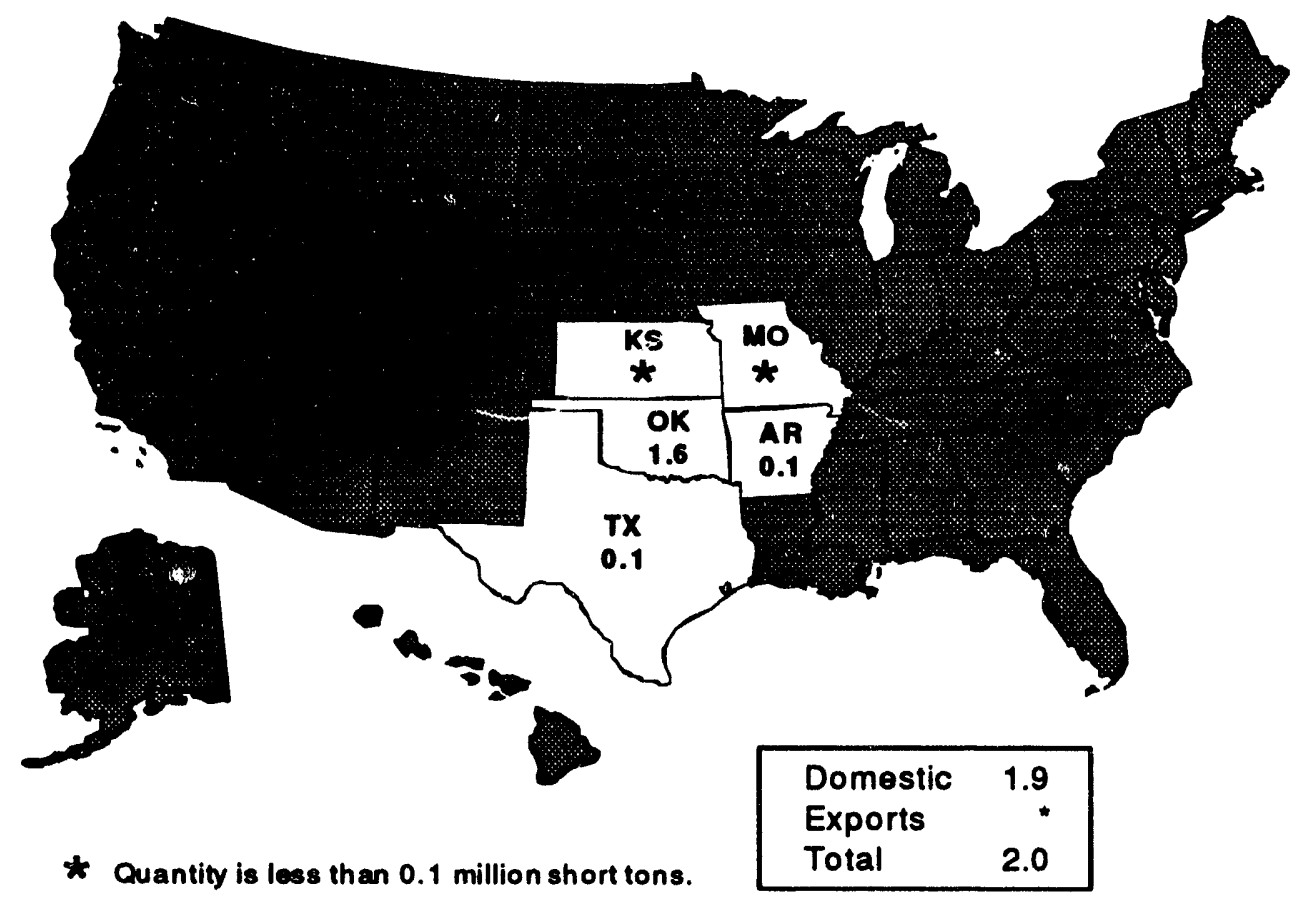

Transportation modes, domestic markets (percent): rail, 9; truck, 91.

Note: Total may not equal sum of components because of independent rounding.

Source: Energy Information Administration, Form EIA-6, "Coal Distribution Report."

\section{Origin of Coal Recelved in Oklahoma, "}

(Million Short Tons)

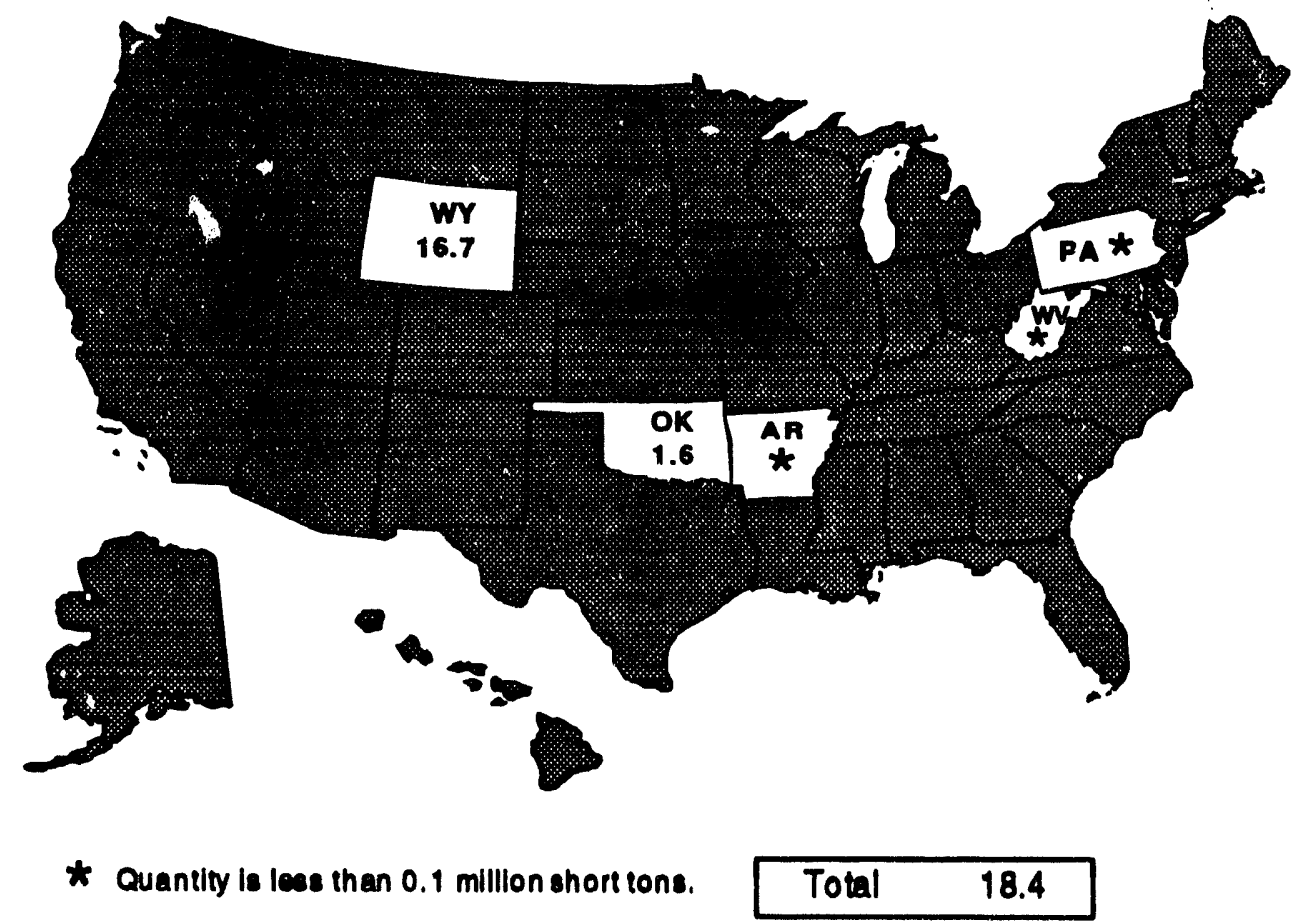

Note: Total may not equal sum of components because of independent rounding.

Source: Energy Information Administration, Form EIA-6, "Coal Distribution Report." 


\section{State Coal Profile: Pennsylvania}

Pennsylvania has long been a major source of coal, leading the Nation in coal production until the early 1950's and ranking among the top coal producers since then. Cumulative production is more than 15 billion short tons, an amount far exceeding that from any other State. In 1992, coal was Pennsylvania's most valuable mineral resource, the value of production representing an estimated 60 percent of the total value of all mineral commodities produced.

Pennsylvania's coal deposits consist of bituminous coal and anthracite. Bituminous coal underlies most of the western part of the State in flat-lying beds. Anthracite deposits occur in four fields in the East and are intensely folded and faulted. Virtually all U.S. anthracite production has been from these fields.

About 40 coalbeds are mined. The major beds of bituminous coal, about 3 to 6 feet thick, are the Pittsburgh, Upper and Lower Freeport, and Upper and Lower Kittanning. An important source of anthracite is the Mammoth coal zone. This comprises several 5- to 6-foot-thick coalbeds that merge in places into one bed more than $\mathbf{5 0}$ feet thick. Some bituminous coal is used to produce metallurgical coke. Anthracite is sometimes blended with coking coal to improve the physical properties of the coke produced.

Bituminous coal was first mined in Pennsylvania in 1760 near present-day Pittsburgh. By the mid-1800's, it was widely used as a fuel for domestic use and the salt and glass industries. The State's bituminous coal industry grew with the development of the iron and steel industry and the rising use of coal-fired steam power. Although used by blacksmiths at Wilkes-Barre in 1769, anthracite was not widely accepted as a fuel until the early 1800 's, when the problem of keeping it burning was solved by the use of specially designed grates and stoves.

The development of canals, railroads, and river transportation opened up markets for both bituminous coal and anthracite. In 1918, output was a record 277 million short tons, a level unequalled by any other State. Production dropped during the Depression before climbing to more than 200 million short tons during World War II. Output then decreased due to competi- tion from other fuels, the loss of the large railroad market as diesel-electric locomotives replaced coal-fired locomotives, and a falling demand for coal by the iron and steel industry. Anthracite production dropped from over $\mathbf{4 0}$ million short tons in 1950 to about 3 million short tons in recent years. Bituminous coal production fell from over 100 million short tons in 1950 to 65 million short tons in 1992.

The dominance of underground coal mining in Pennsylvania declined with the rise in surface mining after World War II. In 1992, underground mines accounted for about two-thirds of the State's output. The Bailey No. 1 mine of Consolidation Coal Company in Greene County was the largest underground coal mine in both the State and the country, producing about 6 million short tons. The company's Bailey coal preparation plant, with a capacity of 3,200 short tons per hour, was the Nation's largest. Greene County was the leading coal-producing county. Anthracite production was chiefly from surface mines in Schuylkill County.

A little more than half of the coal produced from Pennsylvania's mines in 1992 remained in the State. The leading out-of-State shipments were to New York, Ohio, and Maryland. Of the 6 million short tons exported, three-fourths went overseas and the rest to Canada.

In 1992, Pennsylvania was the fourth-largest coalconsuming State, using 56 million short tons. Electric power plants were the principal coal consumers. The State's mines provided about three-fourths of the utility coal used, and West Virginia supplied most of the remainder. Anthracite culm and silt (waste materials from preparation plants) were also used as utility fuel. The State's largest coal-burning generating facility is the 2,360-megawatt Bruce Mansfield plant of Pennsylvania Power Company, in Beaver County. Coke plants, the second-largest coal consumers in the State, received about one-fourth of their needs from Pennsylvania and the rest from West Virginia, Virginia, and Kentucky. Pennsylvania was the largest coke-producing Sta e in 1992, with nearly one-third of the U.S. total. Other industrial consumption was mainly at cement plants and paper mills. Anthracite predominated in the residential and commerial sectors. 


\section{Pennsylvania}
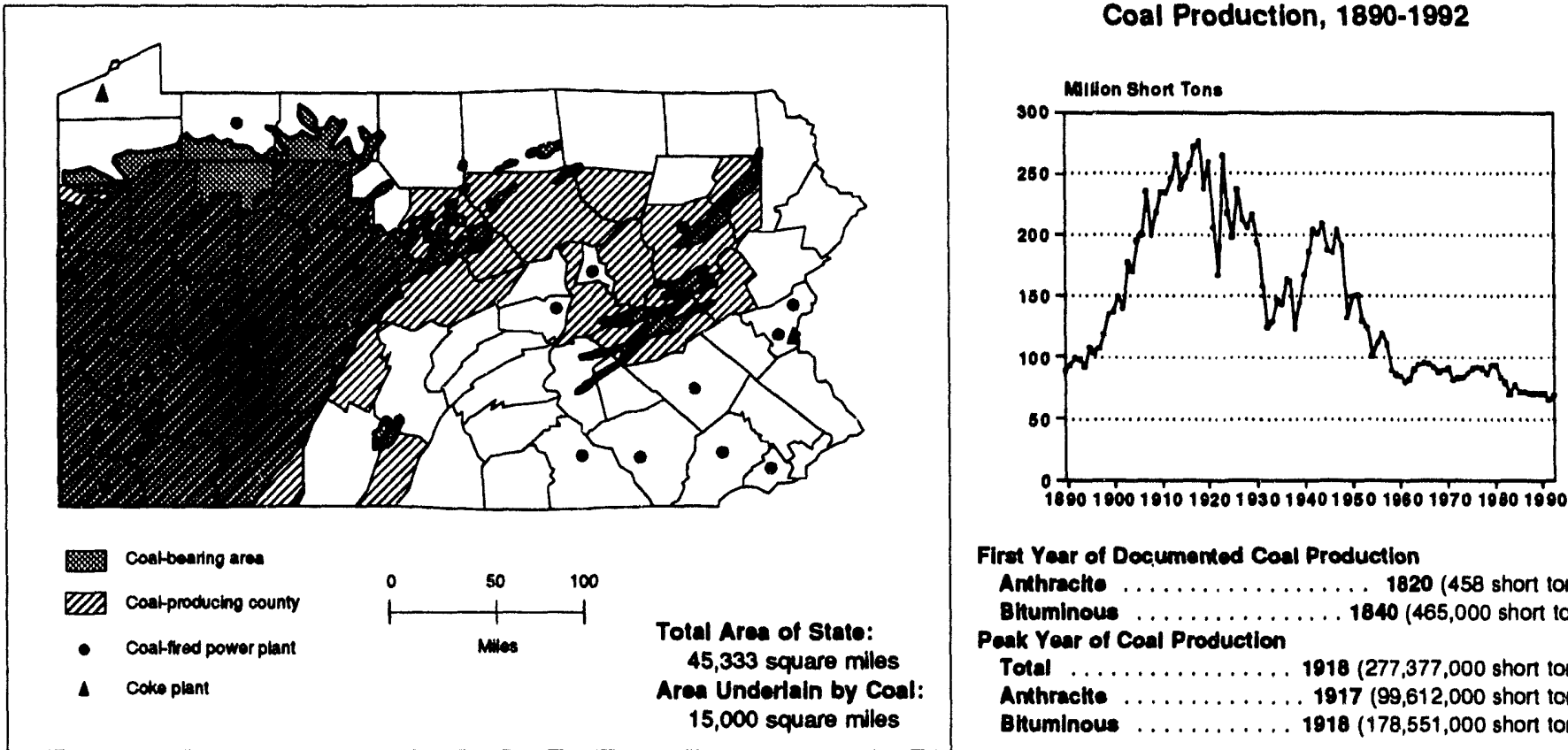

First Year of Decumented Coal Production

Anthrectte . . . . . . . . . . . 1820 (458 short tons).

Bhuminous . . . . . . . . . 1840 (465,000 short tons) Paak Year of Coal Production

Total . . . . . . . . . . . 1918 (277,377,000 shon tons).

Anthracte . . . . . . . . 1917 (99,612,000 shont tons).

Btuminous . . . . . . . 1918 (178,551,000 short tons).

Coal Reserves (Million Short Tons)

\begin{tabular}{|c|c|c|c|}
\hline Type of Reserve & Underground & Surtace & Total \\
\hline $\begin{array}{l}\text { Demonstrated Reserve Baso: } \\
\text { (January 1, 1992) } \ldots \ldots \ldots \ldots \ldots \ldots \ldots \ldots \ldots \ldots \\
\text { Estimated Recoverabio Recervec: } \\
\text { (January } 1,1992 \text { ) } \\
\text { Sultur Content (pounds per million Btu) }\end{array}$ & 24,652 & 4,537 & 29,189 \\
\hline $\begin{array}{l}<0.61 \text { (low sulfur) } \ldots \ldots \ldots \ldots \ldots \ldots \ldots \ldots \ldots \ldots \ldots \\
0.61-1.67 \text { (medium sulfur) } \ldots \ldots \ldots \ldots \ldots \ldots \ldots \ldots \\
>1.67 \text { (high sulfur) } \ldots \ldots \ldots \ldots \ldots \ldots \ldots\end{array}$ & $\begin{array}{r}563 \\
5,541 \\
5,367\end{array}$ & $\begin{array}{l}372 \\
468 \\
388\end{array}$ & $\begin{array}{r}936 \\
6,009 \\
5,756\end{array}$ \\
\hline 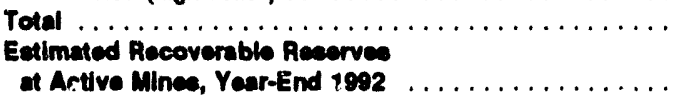 & $\begin{array}{r}11,472 \\
723\end{array}$ & $\begin{array}{r}1,229 \\
214\end{array}$ & $\begin{array}{r}12,700 \\
937\end{array}$ \\
\hline
\end{tabular}

\section{Production}

\begin{tabular}{|c|c|c|c|c|c|}
\hline Sallent Data by Mine Type & 1980 & 1985 & 1890 & 1991 & 1992 \\
\hline \multicolumn{6}{|l|}{ Undereround } \\
\hline Quantity (thousand short tons) $\ldots \ldots \ldots \ldots \ldots \ldots \ldots$ & 43,474 & 36,590 & 40,530 & 40,953 & 45,112 \\
\hline 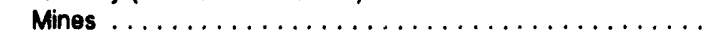 & 124 & 196 & 153 & 139 & 140 \\
\hline Miners $\ldots \ldots \ldots \ldots \ldots \ldots \ldots \ldots \ldots \ldots$ & 23,442 & 14,185 & 9,937 & 8,751 & 8,113 \\
\hline Productivity (shon tons per miner per hour) $\ldots \ldots \ldots \ldots \ldots$ & .99 & 1.37 & 2.12 & 2.38 & 2.81 \\
\hline Average Nine Price (dollars per shont ton) . . . . . . . . . & 37.64 & 36.25 & 33.23 & 31.72 & 30.23 \\
\hline \multicolumn{6}{|l|}{ Surtace } \\
\hline Quantity (thousand short tons) $\ldots \ldots \ldots \ldots \ldots \ldots \ldots$ & 49,651 & 34,818 & 29,984 & 24,429 & 23,868 \\
\hline Mines $\ldots \ldots \ldots \ldots \ldots \ldots \ldots \ldots \ldots \ldots \ldots$ & 549 & 578 & 520 & 469 & 438 \\
\hline 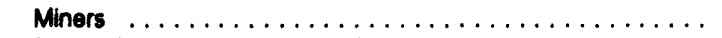 & 12,476 & 8,022 & 5,962 & 4,755 & 4,546 \\
\hline Productivity (short tons per miner per hour) $\ldots \ldots \ldots \ldots \ldots$ & 2.11 & 2.11 & 2.42 & 2.53 & 2.45 \\
\hline Average Mine Price (dollars per short ton) . . . . . . . . . & 25.87 & 29.35 & 25.91 & 25.42 & 25.48 \\
\hline \multicolumn{6}{|l|}{ Totel } \\
\hline Quantity (thousand short tons) & 93,125 & 71,408 & 70,514 & 65,381 & 68,981 \\
\hline Mines ............... & 673 & 774 & 673 & 608 & 578 \\
\hline 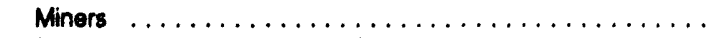 & 35,918 & 22,207 & 15,895 & 13,506 & 12,659 \\
\hline Productivity (shon tons per miner per hour) $\ldots \ldots \ldots \ldots$ & 1.41 & 1.65 & 2.24 & 2.43 & 2.67 \\
\hline Average Mine Price (dollars per short ton) $\ldots \ldots \ldots \ldots \ldots$ & 31.12 & 32.91 & 30.15 & 29.40 & 28.61 \\
\hline
\end{tabular}




\section{Pennsylvania}

Number of Mines by Production Range and Percent of Production, 1992

\begin{tabular}{|c|c|c|c|c|c|c|c|c|}
\hline \multirow{3}{*}{ Mine Type } & \multicolumn{8}{|c|}{ Production Range (thousand short tons) } \\
\hline & \multicolumn{2}{|c|}{1,000 and over } & \multicolumn{2}{|c|}{500 to 999} & \multicolumn{2}{|c|}{100 to 499} & \multicolumn{2}{|c|}{$<100$} \\
\hline & Number & Percent & Number & Percent & Number & Percont & Number & Percent \\
\hline Underground & 10 & 65 & 11 & 16 & 30 & 16 & 89 & 3 \\
\hline Surtace $\ldots \ldots \ldots \ldots \ldots \ldots \ldots \ldots \ldots \ldots$ & 1 & 6 & 5 & 16 & 50 & 42 & 382 & 36 \\
\hline All Mines ........ & 11 & 44 & 16 & 16 & 80 & 25 & 471 & 15 \\
\hline
\end{tabular}

\section{Coal Demand}

\begin{tabular}{|c|c|c|c|c|c|}
\hline Dlepocition & 1980 & 1986 & 1990 & 1901 & 1992 \\
\hline \multicolumn{6}{|l|}{ Consumptien (thousand short tons) } \\
\hline Electric Uullities $\ldots \ldots \ldots \ldots \ldots \ldots$ & 42,465 & 41,713 & 41,465 & 40,662 & 40,407 \\
\hline Coke Pients $\ldots \ldots \ldots \ldots \ldots \ldots \ldots \ldots$ & 17,065 & 9,762 & 10,456 & 8,812 & 9,868 \\
\hline Other Industrial $\ldots \ldots \ldots \ldots \ldots \ldots \ldots$ & 4,391 & 3,852 & 4,090 & 4,049 & 4,243 \\
\hline Residential and Commercial .......... & 1,521 & 1,226 & 1,308 & 1,408 & 1,626 \\
\hline Total $\ldots \ldots \ldots \ldots \ldots \ldots \ldots \ldots$ & 65,442 & 56,553 & 57,319 & 54,931 & 56,144 \\
\hline \multicolumn{6}{|l|}{ Year-End Uillty Stocks } \\
\hline (thousand short tons) $\ldots \ldots \ldots \ldots \ldots$ & 11,622 & 13,628 & 14,363 & 14,412 & 14,866 \\
\hline \multicolumn{6}{|l|}{ Electivelty Ceneration } \\
\hline Total (mililion kilowatthours) . . . . . . . . . & 122,510 & 135,018 & 165,683 & 162,367 & 166,034 \\
\hline Coal (percent) $\ldots \ldots \ldots \ldots \ldots \ldots \ldots$ & 81 & 74 & 62 & 62 & 62 \\
\hline Nudear (percent) $\ldots \ldots \ldots \ldots \ldots \ldots$ & 10 & 18 & 35 & 35 & 36 \\
\hline Other (percent) $\ldots \ldots \ldots \ldots \ldots \ldots \ldots$ & 9 & 7 & 3 & 3 & 2 \\
\hline \multicolumn{2}{|c|}{ Average Cuallty and Average Dellvered Cost } & \multicolumn{2}{|c|}{ Produced In state } & \multicolumn{2}{|c|}{ Rocolpts, All Sources } \\
\hline \multicolumn{3}{|c|}{ Heat Content (million Btu per short ton) $\ldots \ldots \ldots \ldots \ldots \ldots \ldots$} & 25.10 & \multicolumn{2}{|c|}{24.80} \\
\hline \multicolumn{3}{|c|}{ Sulfur Content (percent by woight) $\ldots \ldots \ldots \ldots \ldots \ldots \ldots$} & & \multicolumn{2}{|c|}{2.12} \\
\hline \multicolumn{2}{|c|}{ Ash Content (percent by weight) $\ldots \ldots \ldots \ldots \ldots \ldots \ldots \ldots$} & \multicolumn{2}{|c|}{$\begin{array}{r}1.85 \\
11.59\end{array}$} & \multicolumn{2}{|c|}{12.56} \\
\hline \multicolumn{3}{|c|}{ Pounds of Sulfur per million Btu $\ldots \ldots \ldots \ldots \ldots \ldots \ldots \ldots$} & 1.47 & \multicolumn{2}{|c|}{1.71} \\
\hline \multicolumn{3}{|c|}{ Dollars per million Btu $\ldots \ldots \ldots \ldots \ldots \ldots \ldots \ldots \ldots$} & & \multicolumn{2}{|c|}{1.48} \\
\hline \multicolumn{2}{|c|}{ Dollars per short ton $\ldots \ldots \ldots \ldots \ldots \ldots \ldots \ldots \ldots$} & & & \multicolumn{2}{|c|}{36.81} \\
\hline
\end{tabular}

Eetimated Total State Energy Consumption, 1991: 3,492 trillion Btu (coal, 1,365; natural gas, 662; potroleum, 1,243; nuclear electric power, 617; hydroelectic power, 7; othor, 0; net interatato flow of electriclty and aseoclated losese, -402 ).

Notes: Totals may not equal sum of components because of independent rounding. Date coverage-Productlon: all mines. Number of mines: 1980, mines that produced 10,000 short tons or more; other years, alf mines. Number of miners and productivity: mines that produced 10,000 or more short tons and preparation plants that had 5,000 or more employee hours. Average mine price: mines that produced 10,000 or more shor tons. Average qualty and average dellvered coet of utliky coal: power plants with a generator nameplate capacity of 50 megawatts or more. Extent of coal-bearing areas and locations of coalconsuming plants shown on map are approximate; small coal deposits are not shown. Coal-producing counties shown on map exclude any county where all 1992 output was from mines producing less than 10,000 short tons.

Sources: Energy Information Administration-U.S. Coal Peserves: An Update by Heat and Sulfur Content, February 1993; Coal Production 1992 and prior issues; Cod Data: A Reference; Quarterly Coal Report October-December 1992 and prior issues; Eloctric Power Annual 1991 and prior issues; Electric Power Monthy, March 1993; Cost and Quality of Fuels for Electric Power Plants 1992; Inventory of Power Plants in the United States 1992; State Energy Data Report 1991: CC 2sumption Estimates; Map of coal-bearing areas is based mainly on U.S. Geological Survey map, Coalfields of the United States, 1960. Data for historical graph 1800-1975, U.S. Department of the Interior, Geological Survey and Bureau of Mines (Minerals Yearbook and annual predecessor Mineral Resources of the United Stated); 1976 forward, Energy Information Administration, Coal Production 1992 and prior issues. 


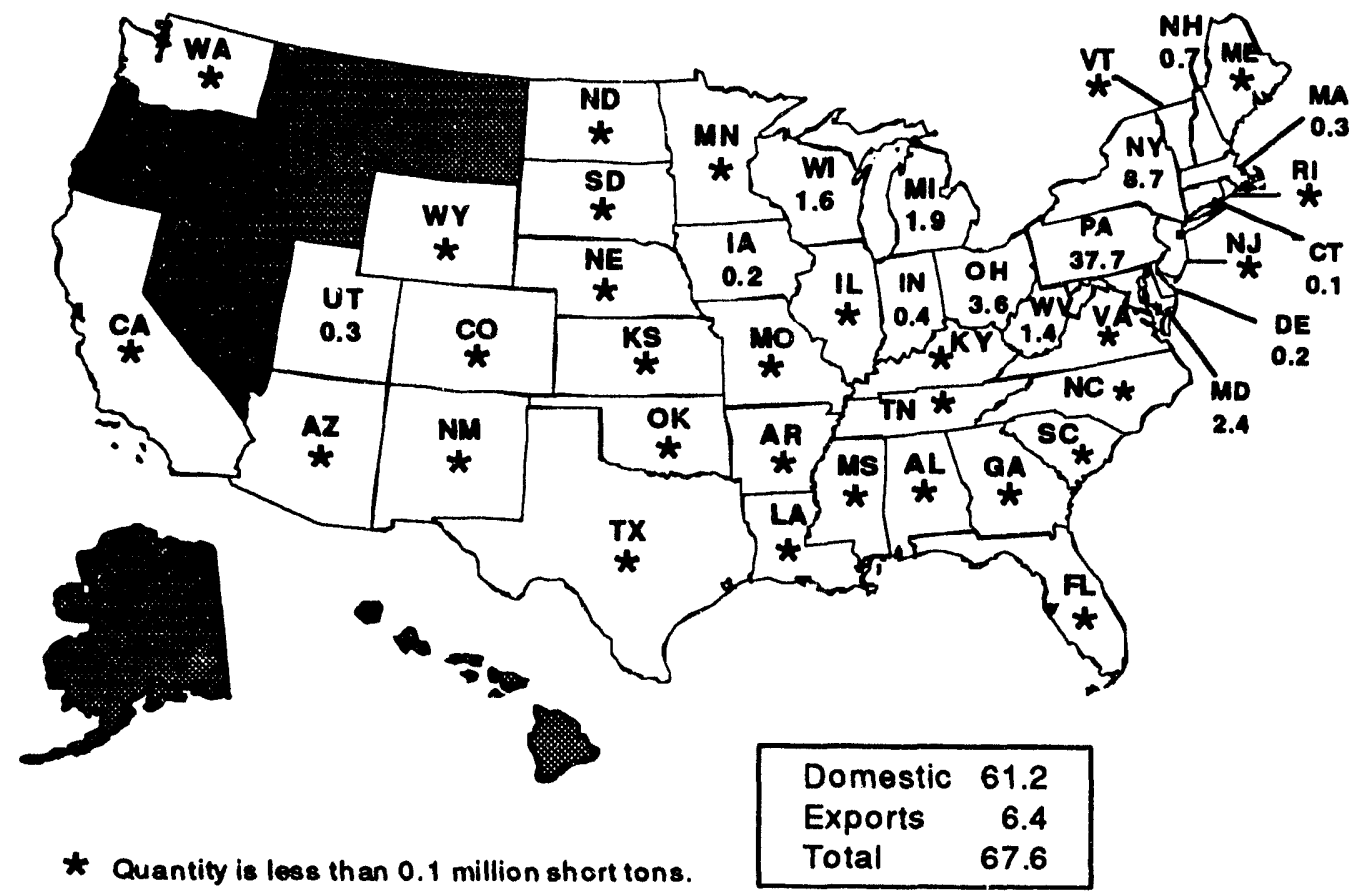

Transportation modes, domestic markets (percent): rail, 46; water, 15; truck, 24; tramway/conveyor, 12; unknown, 2.

Note: Total may not equal sum of components because of independent rounding.

Source: Energy Information Administration, Form EIA-6, "Coal Distribution Report."

Origin of Coal Recelved in Pennsylvanla, 1992

(Million Short Tons)

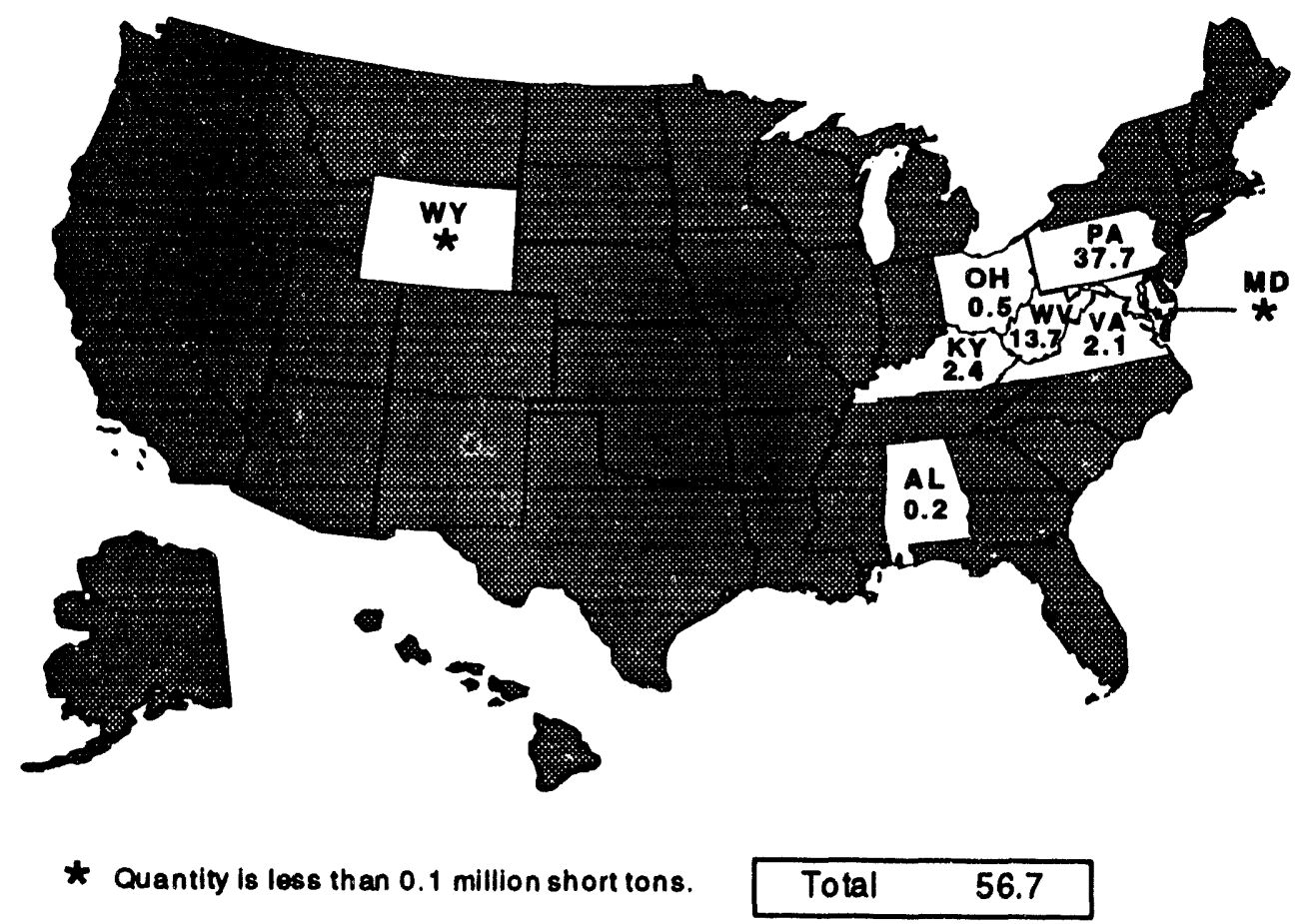

Note: Total may not equal sum of components because of independent rounding.

Source: Energy Information Administration, Form EIA-6, "Coal Distribution Report." 


\section{State Coal Profile: Tennessee}

Coal is the leading mineral fuel produced in Tennessee. The coal output in 1992 accounted for about 10 percent of the total estimated value of all mineral commodities produced in the State.

Tennessee's coalfields, located in the eastern part of the State, are part of the Appalachian coal region. The coalbearing area covers a northeasterly trending belt ranging from $\mathbf{5 0}$ to 70 miles in width. All the coal is bituminous in rank. Some of it can be converted into metallurgical coke, but none is currently produced for this purpose. Although about 12 coalbeds were mined in 1992, production was largely from the Sewanee, Beach Grove, and Jellico beds, which average 3 to 4 feet in thickness.

The first recorded use of coal in Tennessee was in 1814, when coal was mined by blacksmiths for forging iron near what is now Rockwood, in Roane County. Most of the early efforts to mine Tennessee coal commercially were unsuccessful because of transportation difficulties and lack of steady demand. The arrival of the railroads in the Tennessee coalfields provided a two-fold impetus to mine coal. In addition to transporting coal to distant markets, the railroads were also consumers of coal. Following the completion of the Tennessee Central Railway in the early 1900 's, production rose almost steadily through World War I, reaching nearly 7 million short tons.

After a setback due partly to the Depression and the development of hydropower in the State, production expanded to about 8 million short tons during World War II. The postwar coal industry, however, experienced a loss of two of its major markets. Coal once widely used for space heating was replaced by oil and gas, and coal-fired locomotives were phased out by diesel-electric engines. These losses were later offset as coal demand increased when the Tennessee Valley Authority (TVA) constructed a series of coal-fired power plants in the State. As a result, coal output rose to a record 11 million short tons in 1972 . Since then, however, Tennessee's coal production has been trending downward, as the output from surface mines has fallen due to the high cost of working thin, discontinuous coalbeds under thick overburden. The State's coal output dropped to 3 million short tons in 1992.

Underground mines have been the major source of coal production in Tennessee. Before 1938, all coal produced in the State was from underground mines. The output from surface mines gained importance after World War II. In 1992, the leading source of coal was the Underground No. 6 mine of Cross Mountain Coal, Inc., in Campbell County. Tennessee's leading coalproducing counties were Campbell and Sequatchie.

About two-thirds of the coal shipped from Tennessee's mines in 1992 was used to generate electricity, and the rest was mostly for other industrial use. Nearly 60 percent of the coal distributed remained in the State. Most of the shipments out of Tennessee went to Alabama, and a small amount was exported.

More than 80 percent of the 24 million short tons of coal consumed in Tennessee was used to generate electricity. About three-fourths of this coal was from Kentucky; Tennessee's mines supplied about 6 percent of the total. The largest coal-fired power plant in Tennessee is TVA's 2,494-megawatt Cumberland plant, in Stewart County. The leading coal consumer in the industrial sector was Tennessee Eastman Company, a unit of Eastman Chemicals Division of the Eastman Kodak Company, located in Kingsport. The company's coal gasification plant, in operation since 1983, is one of three commercial coal gasification plants in the United States. This coal gasification plant uses coal as a feedstock to manufacture acetic anhydride, used in the production of cellulose acetate for photographic film base. 


\section{Tennessee}

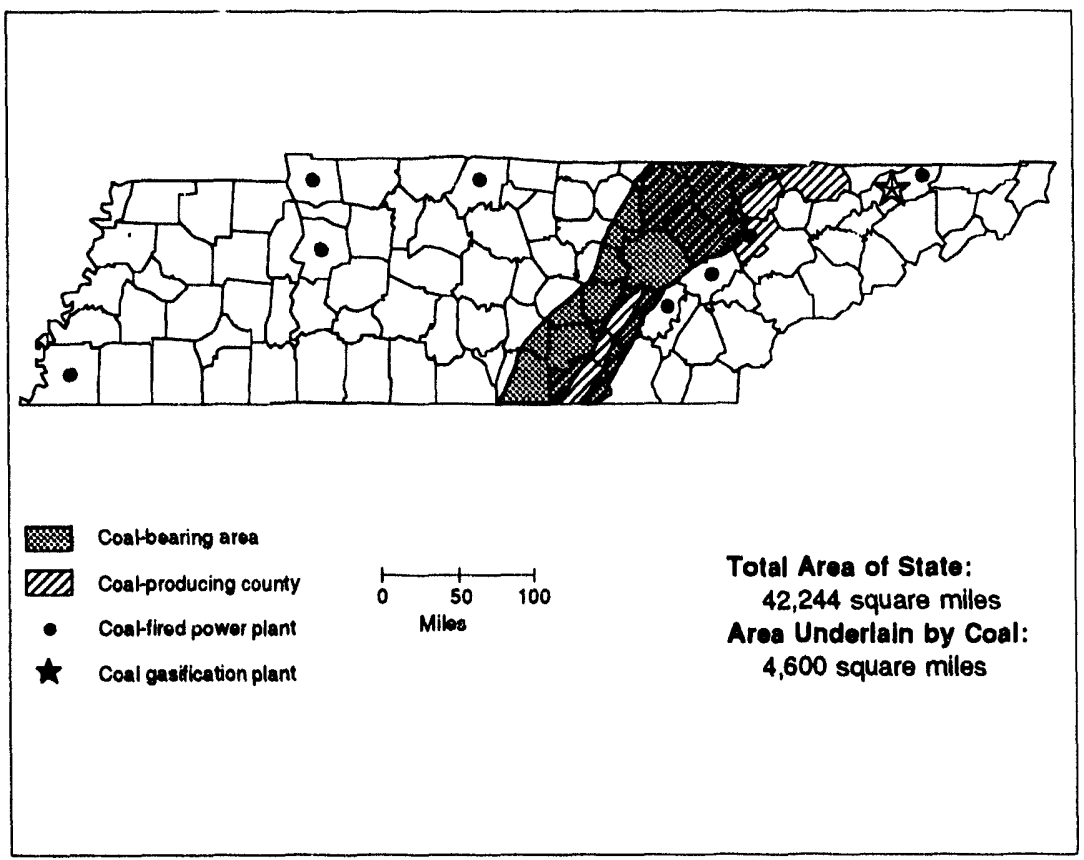

Coal Production, 1890-1992

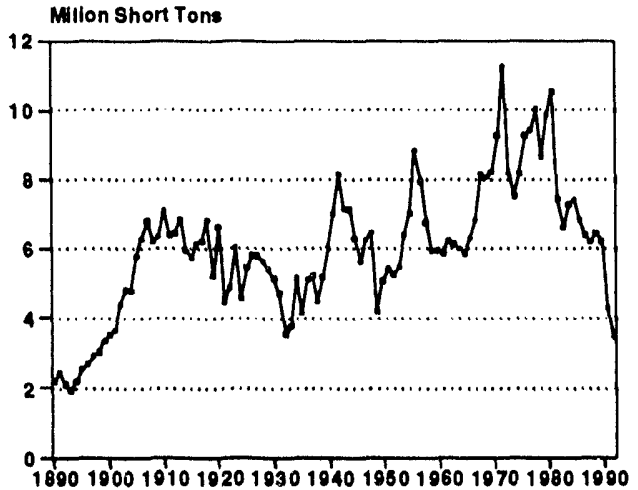

First Year of Documented Coal

Production.

1840 (558 short tons)

Peak Year of Coal

Production

$1972(11,260,000$ short tons)

\section{Coal Reserves (Million Short Tons)}

\begin{tabular}{|c|c|c|c|}
\hline Type of Reserve & Underground & Surlace & Total \\
\hline \multicolumn{4}{|l|}{ Demonstrated Reserve Base: } \\
\hline (January 1, 1992) ........ & 551 & 293 & 843 \\
\hline$<0.61$ (low sulfur) $\ldots \ldots \ldots \ldots$ & 69 & 39 & 108 \\
\hline $0.61-1.67$ (medium sulfur) $\ldots \ldots \ldots \ldots \ldots \ldots \ldots$ & 173 & 118 & 291 \\
\hline Eotlmated Recovorable Reserves & & & \\
\hline at Active Mines, Year-End 1992 & W & W & 43 \\
\hline
\end{tabular}

\section{Production}

\begin{tabular}{|c|c|c|c|c|c|}
\hline Sallent Data by Mine Typo & 1980 & 1985 & 1990 & 1991 & 1992 \\
\hline \multicolumn{6}{|l|}{ Underground } \\
\hline Quantity (thousand short tons) $\ldots \ldots \ldots \ldots \ldots \ldots$ & 4,750 & 5,204 & 4,526 & 3,060 & 2,039 \\
\hline 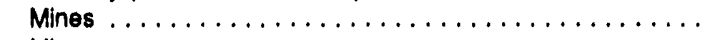 & 54 & 70 & 61 & 50 & 37 \\
\hline 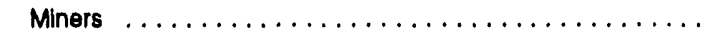 & 2,076 & 1,871 & 1,319 & 988 & 599 \\
\hline Productivity (short tons per miner per hour) . . . . . . . . & 1.21 & 1.50 & 1.68 & 1.72 & 1.81 \\
\hline Average Mine Price (dollars per short ton) . . . . . . . . . . & 29.09 & 29.71 & W & $W$ & W \\
\hline \multicolumn{6}{|l|}{ Surface } \\
\hline Quantity (thousand short tons) $\ldots \ldots \ldots \ldots \ldots \ldots \ldots$ & 5,100 & 2,242 & 1,666 & $i, 230$ & 1,437 \\
\hline 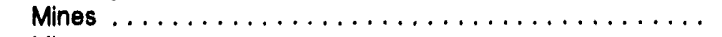 & 63 & 48 & 25 & 22 & 13 \\
\hline 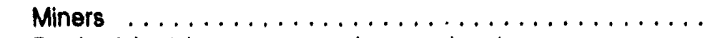 & 1,539 & 751 & 378 & 254 & 205 \\
\hline Productivity (short tons per miner per hour) . . . . . . . . & 1.57 & 1.55 & 2.32 & 2.45 & 3.06 \\
\hline Average Mine Price (dollars per short ton) $\ldots \ldots \ldots \ldots \ldots$ & 25.92 & 25.78 & W & W & W \\
\hline \multicolumn{6}{|l|}{ Total } \\
\hline Quantity (thousand short tons) $\ldots \ldots \ldots \ldots \ldots \ldots$ & 9,850 & 7,446 & 6,193 & 4,290 & 3,476 \\
\hline 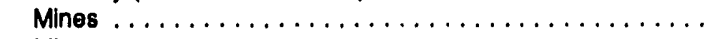 & 117 & 118 & 86 & 72 & 50 \\
\hline 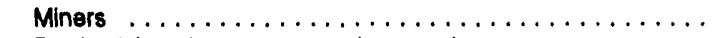 & 3,615 & 2,622 & 1,697 & 1,242 & 804 \\
\hline Productivity (short tons per miner per hour) . . . . . . . . . & 1.36 & 1.51 & 1.81 & 1.88 & 2.19 \\
\hline Average Mine Price (dollars per short ton) $\ldots \ldots \ldots \ldots \ldots$ & 27.54 & 28.54 & 27.96 & 26.74 & 27.11 \\
\hline
\end{tabular}




\section{Tennessee}

Number of Mines by Production Range and Percent of Production, 1992

\begin{tabular}{|c|c|c|c|c|c|c|c|c|}
\hline \multirow{2}{*}{ Mine Typo } & \multicolumn{8}{|c|}{ Production Range (thousand short tons) } \\
\hline & Number & Percent & Number & Percent & Number & Percent & Number & Percent \\
\hline Underground $\ldots \ldots \ldots \ldots \ldots \ldots \ldots$ & 0 & 0 & 1 & 37 & 4 & 29 & 32 & 34 \\
\hline Surface $\ldots \ldots \ldots \ldots \ldots \ldots \ldots \ldots \ldots \ldots$ & 0 & 0 & 0 & 0 & 5 & 85 & 8 & 15 \\
\hline All Mines $\ldots \ldots \ldots \ldots \ldots \ldots \ldots \ldots$ & 0 & 0 & 1 & 22 & 9 & 52 & 40 & 26 \\
\hline
\end{tabular}

\section{Coal Demand}

\begin{tabular}{|c|c|c|c|c|c|}
\hline Dispoaltion & 1980 & 1985 & 1090 & 1991 & 1992 \\
\hline \multicolumn{6}{|l|}{ Conoumplion (thousand short tons) } \\
\hline Electric Uotllies $\ldots \ldots \ldots \ldots \ldots \ldots$ & 21,679 & 20,853 & 20,814 & 19,216 & 20,263 \\
\hline Coke Plants $\ldots \ldots \ldots \ldots \ldots \ldots \ldots$ & $w$ & $w$ & $w$ & $w$ & 0 \\
\hline Other Industrial . . . . . . . . . . . & $w$ & $w$ & 3,779 & 3,702 & 3,682 \\
\hline Residential and Commercial $\ldots \ldots \ldots$ & $w$ & $w$ & $w$ & $w$ & 157 \\
\hline Total $\ldots \ldots \ldots \ldots \ldots \ldots \ldots \ldots$ & 24,496 & 25,105 & 24,878 & 23,107 & 24,102 \\
\hline \multicolumn{6}{|l|}{ Year-End Uillhy Stocke } \\
\hline (thousand short tons) & 9,200 & 3,846 & 3,596 & 3,148 & 3,016 \\
\hline \multicolumn{6}{|l|}{ Electriclity Generation } \\
\hline Total (million kilowatthours) & 60,211 & 66,581 & 73,903 & 73,932 & 75,395 \\
\hline Cosi (percent) $\ldots . .$. & 84 & 75 & 68 & 63 & 66 \\
\hline Nudees (percent) $\ldots \ldots \ldots \ldots \ldots$ & 1 & 15 & 19 & 22 & 21 \\
\hline Other (percent) $\ldots \ldots \ldots \ldots \ldots \ldots$ & 15 & 10 & 13 & 15 & 13 \\
\hline
\end{tabular}

Utilty Coal Data, 1992

\begin{tabular}{|c|c|c|}
\hline Averege Quality and Average Dellvered Coet & Produced In Stato & Recolpts, All Sources \\
\hline Heat Content (million Btu per short ton) $\ldots \ldots \ldots \ldots \ldots \ldots$ & 25.34 & 24.36 \\
\hline Sultur Content (percent by woight) $\ldots \ldots \ldots \ldots \ldots \ldots \ldots \ldots$ & 1.39 & 2.02 \\
\hline Ash Content (percent by woight) $\ldots \ldots \ldots \ldots \ldots \ldots \ldots \ldots$ & 9.63 & 8.31 \\
\hline Pounds of Sulfur per million Btu $\ldots \ldots \ldots \ldots \ldots \ldots \ldots \ldots$ & 1.10 & 1.66 \\
\hline Dollars per million Btu $\ldots \ldots \ldots \ldots \ldots \ldots \ldots \ldots \ldots$ & 1.33 & 1.27 \\
\hline Dollars per short ton $\ldots \ldots \ldots \ldots \ldots \ldots \ldots \ldots \ldots \ldots$ & 33.63 & 31.01 \\
\hline
\end{tabular}

Eetimated Total State Energy Consumption, 1991: 1,747 tillion Btu (coal, 566; natural gas, 235; petroleum, 567; nuclear electric power, 178; hydroelectric power, 109; ther, 0; net interatate flow of clectricity and aseoclated loseces, 83.

$W=$ Withineid to avoid disclosure of individual company data.

Notes: Data coverege-Production: all mines. Number of mines: 1980, mines that produced 10,000 short tons or more: other years, all mines. Number of miners and productivty: mines that produced 10,000 or more short tons and preparation plants that had 5,000 or more employee hours. Average mine price: mines that produced 10,000 or more short tons. Average quallty and average delivered cost of utllity coal: power plants with a generator nameplate capacity of 50 megawatts or more. Totals ritay not equal sum of components because of independent rounding. Extent of coal-bearing areas and locations of coalconsuming plants shown on map are approximate; small coal deposits are not shown. Coal-producing counties shown on map exclude any county where all 1992 output was from mines producing less than 10,000 short tons. Coal receipts are based on distribution data and may not have actually been received during the year.

Sources: Energy Intormation Administration-U.S. Coal Reserves: An Update by Heat and Sultur Content, February 1993; Coal Producticin 1992 and prior issues; Coal Data: A Reterence; Quanterty Coal Report October-December 1992 and prior issues; Electric Power Annual 1991 and prior issues; Electric Power Monthly, March 1993; Cost and Quality of Fuels for Electric Power Plants 1992; Inventory of Power Plants in the United States 1992; State Energy Data Report 1991: Consumption Estimates; Map of coal-bearing areas is based mainly on U.S. Geological Suney map, Coalfields of the United States, 1960. Data for historical graph 1690-1875, U.S. Department of the interior, Geological Survey and Bureau of Mines (Minerals Yearbook and annual predecessor Mineral Resounces of the United States); 1976 forward, Energy Information Administration, Coal Production 1992 and prior issues. 
Deatination of Coal Produced In Tennessee, 1992

(Million Short Tons)

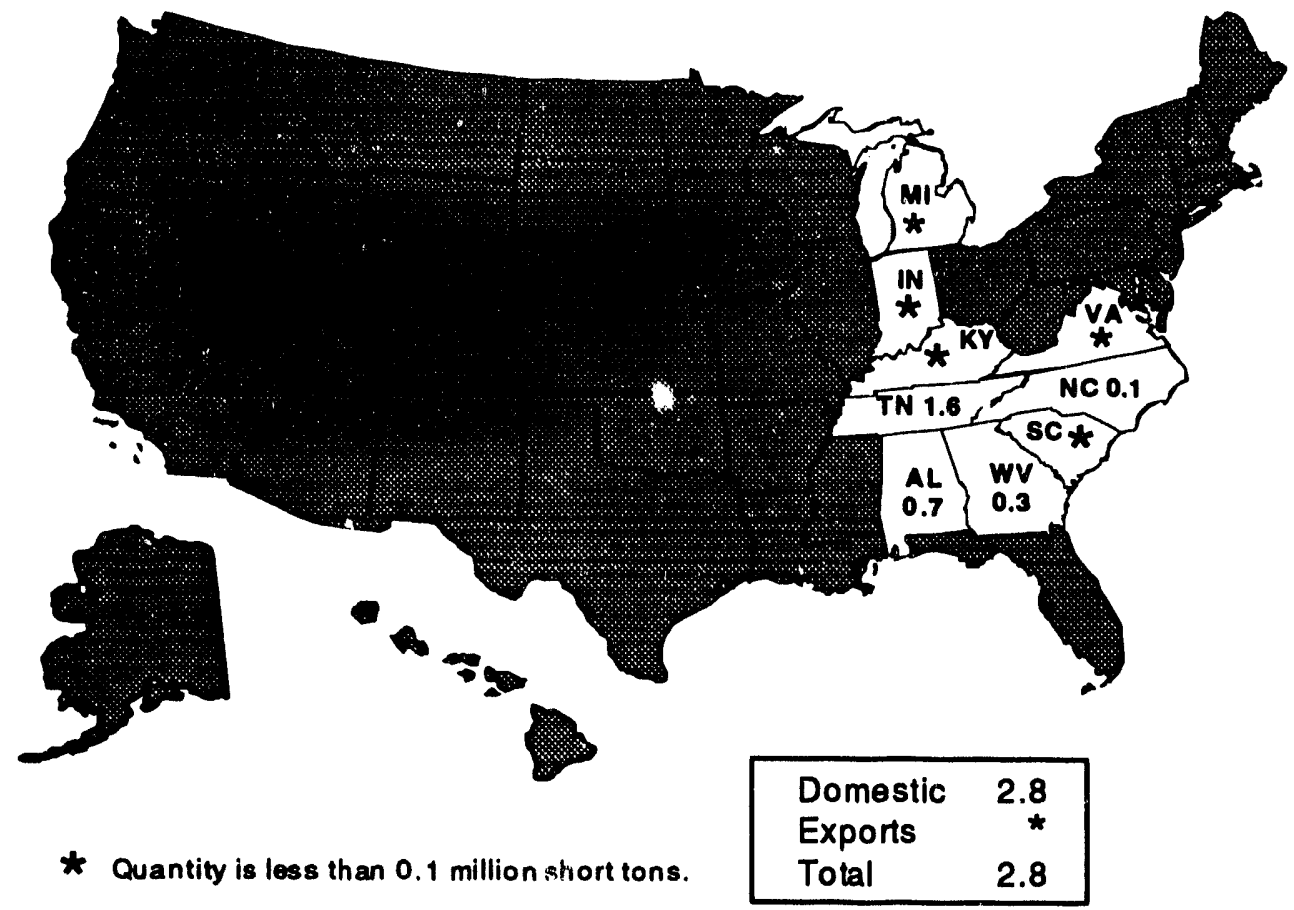

Transportation modes, domestic markets (percent): rail, 60; water, 24; truck, 14; unknown, 2.

Note: Total may not equal sum of components because of independent rounding.

Source: Energy Information Administration, Form EIA-6, "Coal Distribution Report."

\section{Origin of Coal Recelved in Tennessee, 1992}

(Million Short Tons)

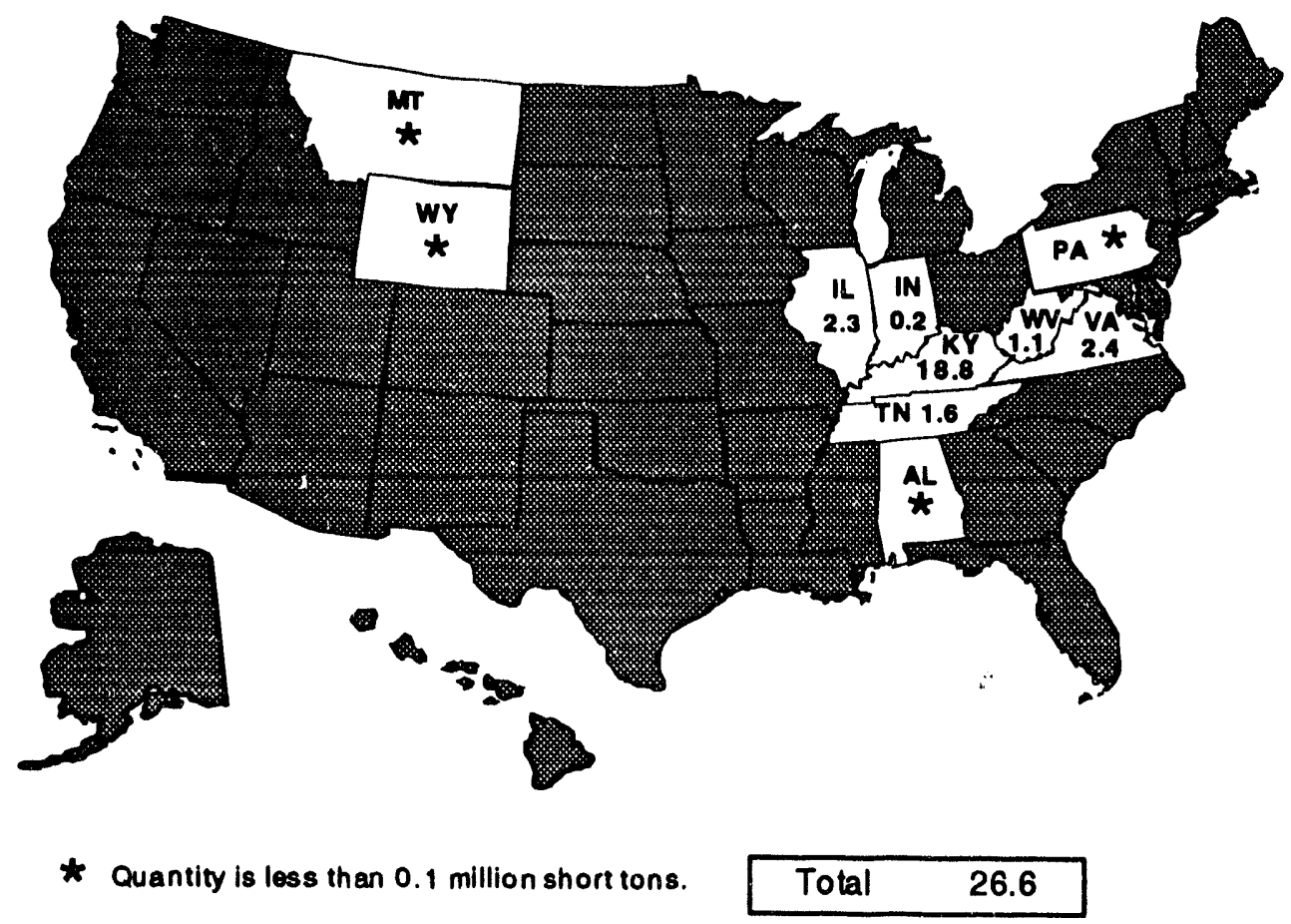

Note: Total may not equal sum of components because of independent rounding.

Source: Energy Information Administration, Form EIA-6, "Coal Distribution Report." 


\section{State Coal Profile: Texas}

Texas ranks first in the United States in the production of lignite. Although greatly overshadowed by crude oil and natural gas production, coal holds an important place in the Texas energy scene.

The lignite deposits in Texas occur chiefly in northeasterly trending belts in the eastern part of the State. The largest commercial deposits are in the Wilcox Formation. The beds mined range from 3 to 10 feet in thickness, although in places two or more beds merge to form a single bed over 20 feet thick. Bituminous coal is found in the north-central, southern, and southwestern parts of Texas, typically in beds 3 feet or less in thickness. Currently, the only bituminous coal produced is from Webb County and is the variety called "cannel coal."

Lignite deposits in Texas were first reported in 1818 and bituminous coal was discovered by the mid-1800's. The early coal industry in Texas produced lignite for local domestic heating and steam generation at cotton gins and other industrial plants. Bituminous coal was produced chiefly for railroad fuel. Total annual coal production reached more than 2 million short tons before 1920. Subsequently, annual coal production declined as markets were lost to oil and gas produced from numerous fields discovered in the State. Bituminous coal production virtually ceased by 1944 , but lignite production continued on a small scale due to the establishment of several industrial markets near lignite deposits. Since 1922, lignite has been used to manufacture activated carbon at a plant in Marshall. In 1926, the Texas Utilities Generating Company began operating the State's first lignite-fired power plant, the Trinidad, in Henderson County. This plant generated electricity from lignite until it converted to natural gas in the early 1940's. The Aluminum Corporation of America has been using lignite since 1954 to generate electricity for its smelter at Rockdale.

The period from the mid-1960's to the mid-1970's was a pivotal time in the development of lignite in Texas as rising natural gas prices created serious concern about economical future sources of energy in the State. In
1971, Texas Utilities Generating Company began operating its newly constructed Big Brown power plant with lignite produced from the nearby Big Brown surface mine. This demonstrated the feasibility of using Texas lignite on a large scale for electricity generation. Further impetus to develop Texas lignite came from the 1973-74 Arab oil embargo and the 1976 order from the Texas Railroad Commission, the State's energy regulatory agency, that limited the future use of natural gas as boiler fuel. At the time, natural gas accounted for more than 85 percent of the electricity generated in Texas, while coal accounted for about 10 percent. The opening of new mines to supply other lignite-fueled power plants in the State contributed to the steady growth of Texas coal output. About 55 million short tons were prov'iced in 1992.

Early coal mining in Texas was mostly by underground methods, but current production is entirely from surface mines. Several of these mines rank among the largest in the United States. The State's largest coal mine, producing about 11 million short tons in 1992, was the Martin Lake mine of Texas Utilities Mining, in Panola County. The top three coal-producing counties were Panola, Titus, and Leon. All of the coal produced (virtually all lignite with less than 1 percent bituminous coal) in Texas was used in the State.

The Nation's leading coal-consuming State since 1981, Texas used 91 million short tons in 1992. Electric power plants were by far the dominant markets, accounting for nearly all of the total. Texas lignite comprised about 60 percent of the utility coal, with Wyoming subbituminous coal accounting for nearly all of the balance. In 1992, the electricity generated from coal in Texas ranked second in the Nation after Ohio. The largest coal-fired generating facility is the 2,335-megawatt $W$. A. Parrish plant of Houston Lighting and Power Company, in Fort Bend County. The plant uses Wyoming coal. Small amounts of coal are consumed mostly in manufacturing activated carbon, cement, and lime, and for generating electricity for aluminum production. Coke production for the State's iron and steel industry ended in 1987. 


\section{Texas}

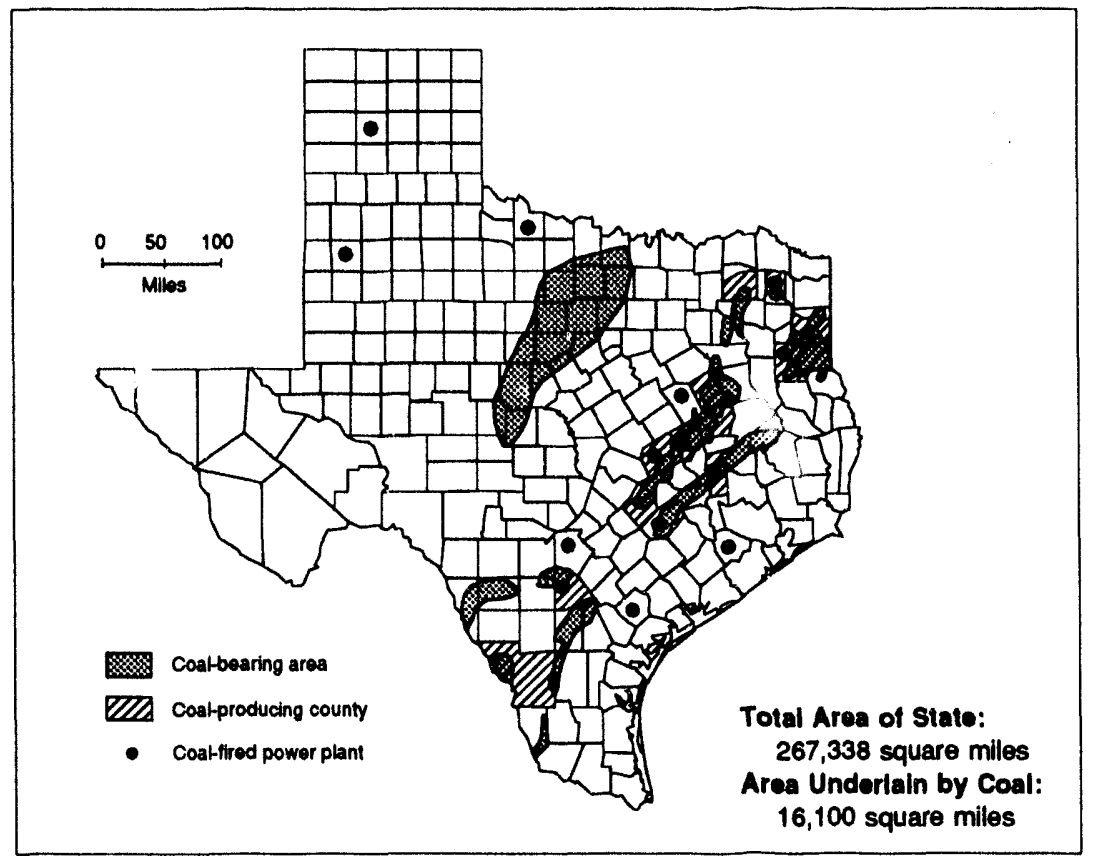

Coal Production, 1890-1992

Millon Short Tone

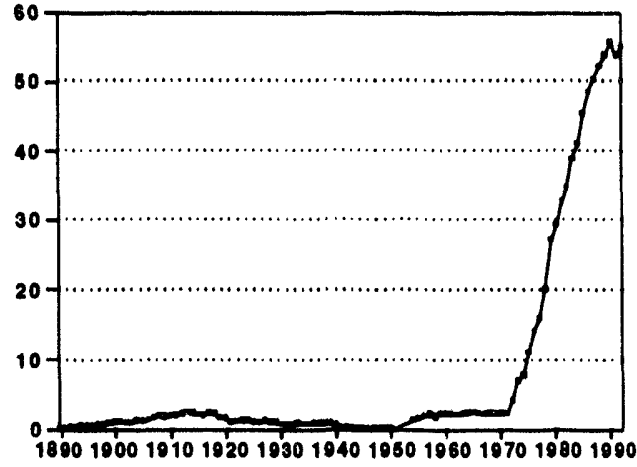

First Year of Documonted Coal

Production . . . . . . . . . . . . 1884 (125,000 short tons)

Pank Yaar of Coal

Production

$1990(55,755,000$ short tons $)$

Coal Reserves (Million Short Tons)

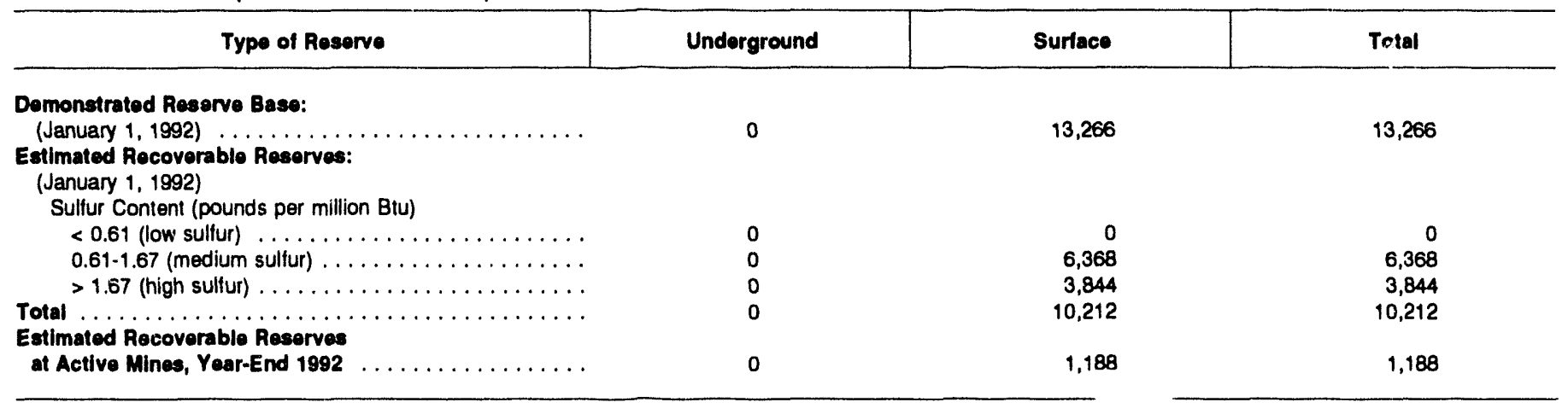

\section{Production}

\begin{tabular}{|c|c|c|c|c|c|}
\hline Sallent Data by Mine Type & 1980 & 1985 & 1980 & 1981 & 1992 \\
\hline \multicolumn{6}{|l|}{ Underground } \\
\hline Quantity (thousand short tons) $\ldots \ldots \ldots \ldots \ldots \ldots$ & 0 & 0 & 0 & 0 & 0 \\
\hline 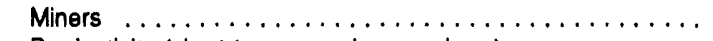 & 0 & 0 & 0 & 0 & 0 \\
\hline Productivity (short tons per miner per hour) $\ldots \ldots \ldots \ldots \ldots$ & -- & .. & -. & -. & -. \\
\hline Average Mine Price (dollars per short ton) $\ldots \ldots \ldots \ldots \ldots$ & $-\cdot$ & .- & -• & -- & -. \\
\hline \multicolumn{6}{|l|}{ Surface } \\
\hline Mines $\ldots \ldots \ldots \ldots \ldots \ldots \ldots \ldots \ldots \ldots \ldots \ldots$ & 10 & 14 & 15 & 15 & 15 \\
\hline$\ldots \ldots \ldots \ldots \ldots \ldots \ldots \ldots \ldots \ldots \ldots$, & 1,780 & 2,360 & 2,131 & 2,149 & 2,001 \\
\hline Productivity (short tons per miner per hour) $\ldots \ldots \ldots \ldots \ldots$ & 5.93 & 6.26 & 7.48 & 7.17 & 7.34 \\
\hline Average Mine Price (dollars per short ton) ............ & 7.67 & 11.60 & 11.20 & 12.21 & 12.42 \\
\hline \multicolumn{6}{|l|}{ Total } \\
\hline Quantity (thousand short tons) & 29,354 & 45,459 & 55,755 & 53,825 & 55,071 \\
\hline
\end{tabular}




\section{Texas}

Number of Mines by Production Range and Percent of Production, 1992

\begin{tabular}{|c|c|c|c|c|c|c|c|c|}
\hline \multirow{3}{*}{ Mine Type } & \multicolumn{8}{|c|}{ Production Range (thousand short tons) } \\
\hline & \multicolumn{2}{|c|}{1,000 and over } & \multicolumn{2}{|c|}{500 to 999} & \multicolumn{2}{|c|}{10010499} & \multicolumn{2}{|c|}{$<100$} \\
\hline & Number & Percent & Number & Percent & Number & Percent & Number & Percent \\
\hline Underground & 0 & 0 & 0 & 0 & 0 & 0 & 0 & 0 \\
\hline Surface $\ldots \ldots \ldots$ & 11 & 99 & 0 & 0 & 4 & 1 & 0 & 0 \\
\hline All Mines ........ & 11 & 99 & 0 & 0 & 4 & 1 & 0 & 0 \\
\hline
\end{tabular}

Coal Demand

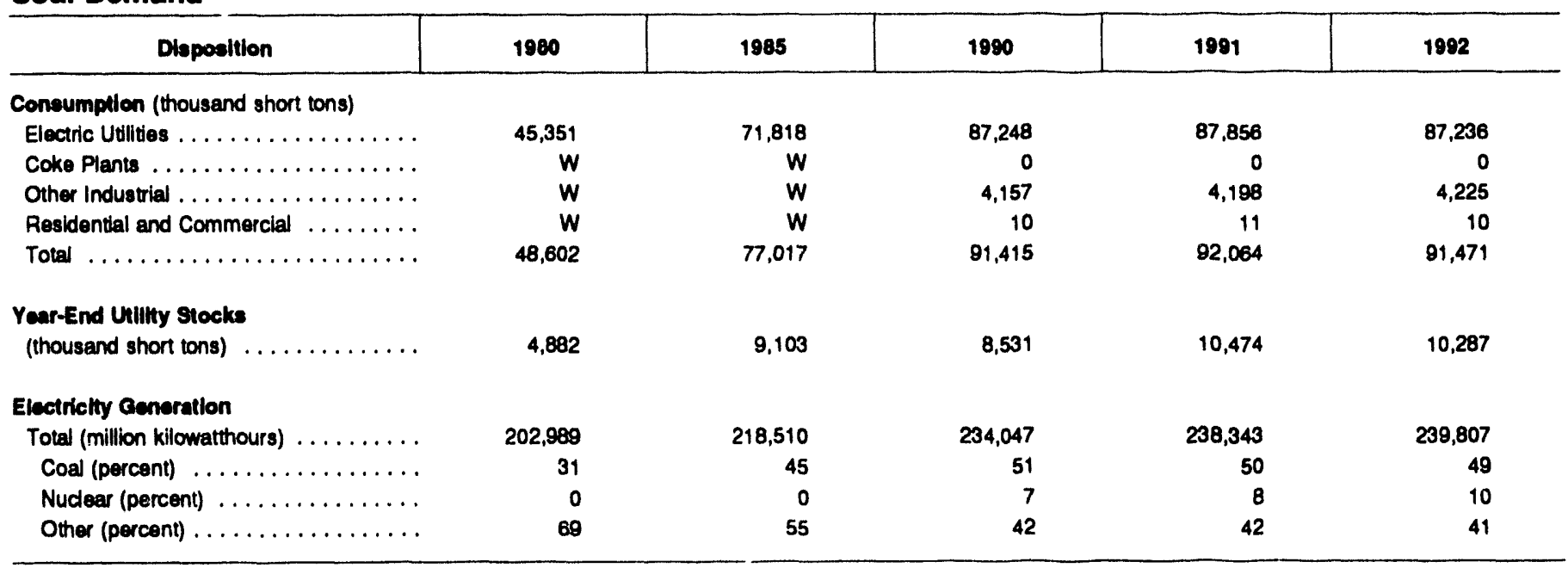

Utility Coal Data, 1992

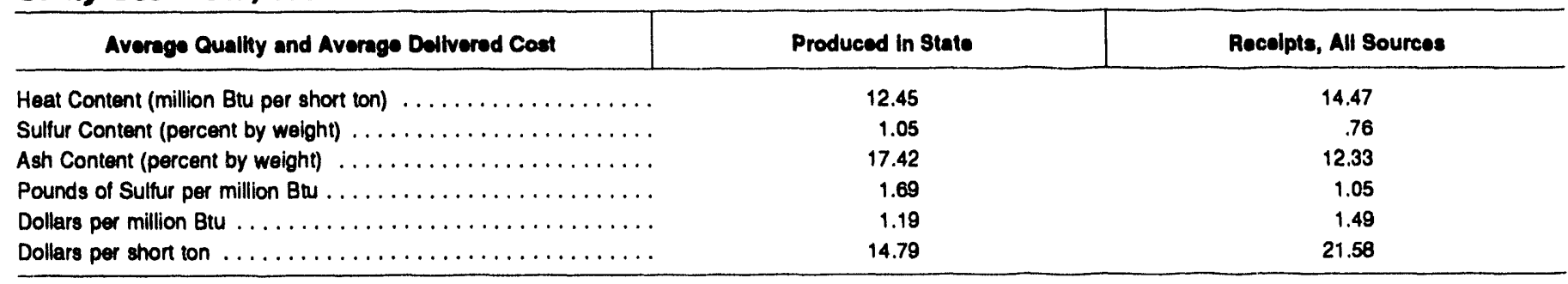

Estimated Total State Energy Consumption, 1991: 9,785 trillion Btu (coal, 1,333; natural gas, 3,716; potroloum, 4,441; nuclear electric power, 213; hydrodectric powor, 18; other, 3; not interstate fiow of electrichy and assoclated loseses, 61.

$W=$ Witheld to avoid disclosure of individual company data.

Notes: Data coverage-Production: all mines. Number of minee: 1980, mines that produced 10,000 short tons or more; other years, all mines. Number of miners and productlvity: mines that produced 10,000 or more short tons and preparation plants that had 5,000 or more employee hours. Average mine price: mines that produced 10,000 or more short tons. Average quality and average delivered coot of utility coal: power plants with a generator nameplate capacity of 50 megawatts or more. Totals may not equal sum of components because of independent rounding. Extent of coal-bearing areas and locations of coalconsuming plants shown on map are approximate; small coal deposits are not shown. Coal-producing Counties shown on map exclude any County where all 1992 output was from mines producing less than 10,000 short tons. Coal receipts are hased on distribution data and may not have actually been received during the year.

Sources: Energy Information Administration-U.S. Coal Reserves: An Update by Heat and Sulfur Content, February 1993 ; Coal Production 1992 and prior issues; Coal Data: A Reference; Quarterly Coal Report October-December 1992 and rrior issues; Electric Power Annual 1991 and prior issues; Electric Power Moithly, March 1993; Cost and Quality of Fuels for Electric Power Plants 1992; Inventory of Power Plants in the United States 1992; State Energy Data Repont 1991: Consumption Estimates; Map of coal-bearing areas is based mainly on U.S. Geological Survey map, Coslfields of the United States, 1960. Data for historical graph 1(100-1975, U.S. Department of t. a Interior, Geological Survey and Bureau of Mines (Minerals Yearbook and annual predecessor Mineral Resources of the United States); 1976 forward, Energy Information Administration, Coal Production 1992 and prior issues. 
Destination of Coal Produced in Texas, 1992

(Million Short Tons)

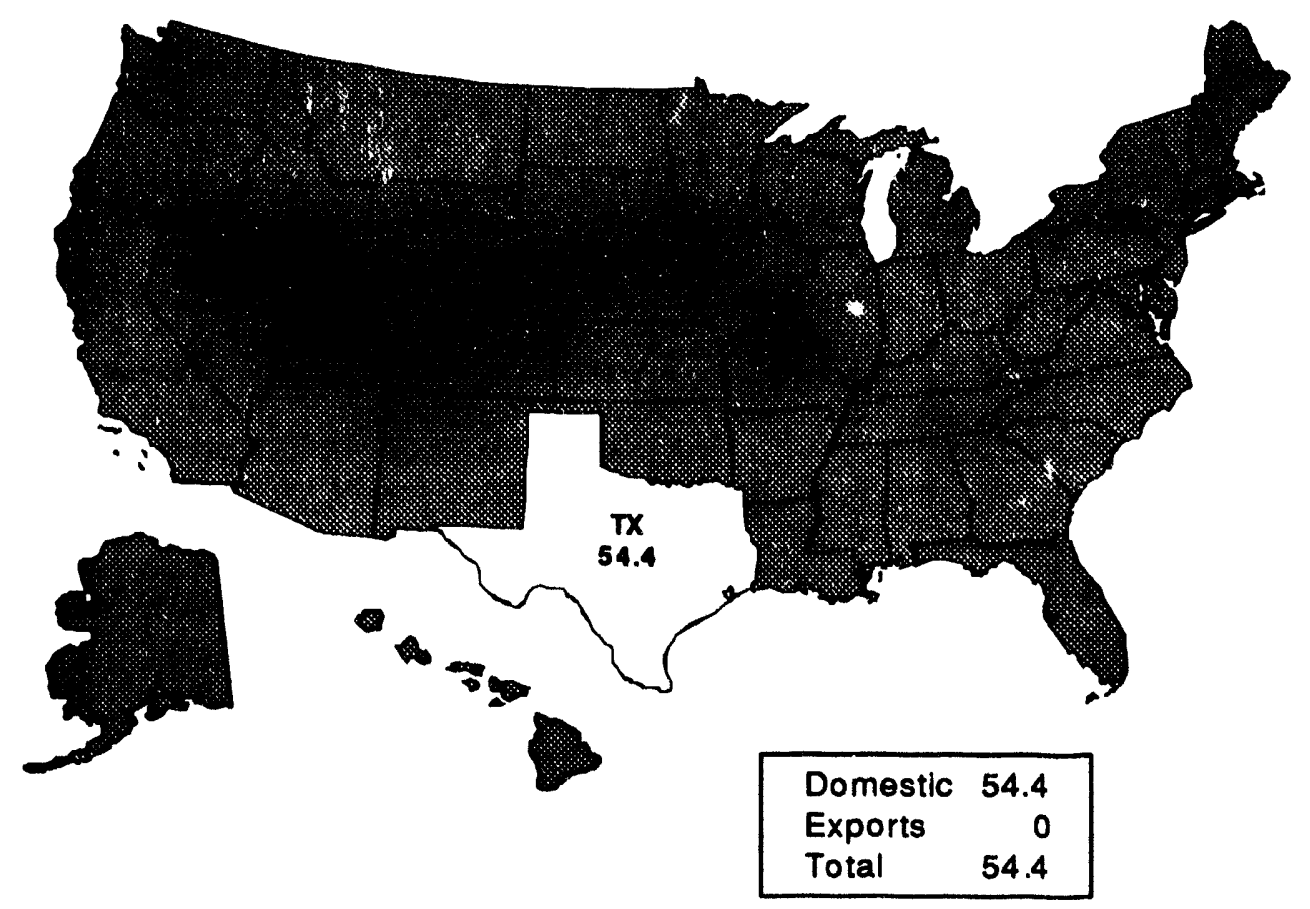

Transportation modes, domestic markets (percent): rail, 47; truck, 24; tramway/conveyor, 29.

Note: Total may not equal sum of components because of independent rounding.

Source: Energy Information Administration, Form ElA-6, "Coal Distribution Report."

Origin of Coal Recelved in Texas, 1992

(Million Short Tons)

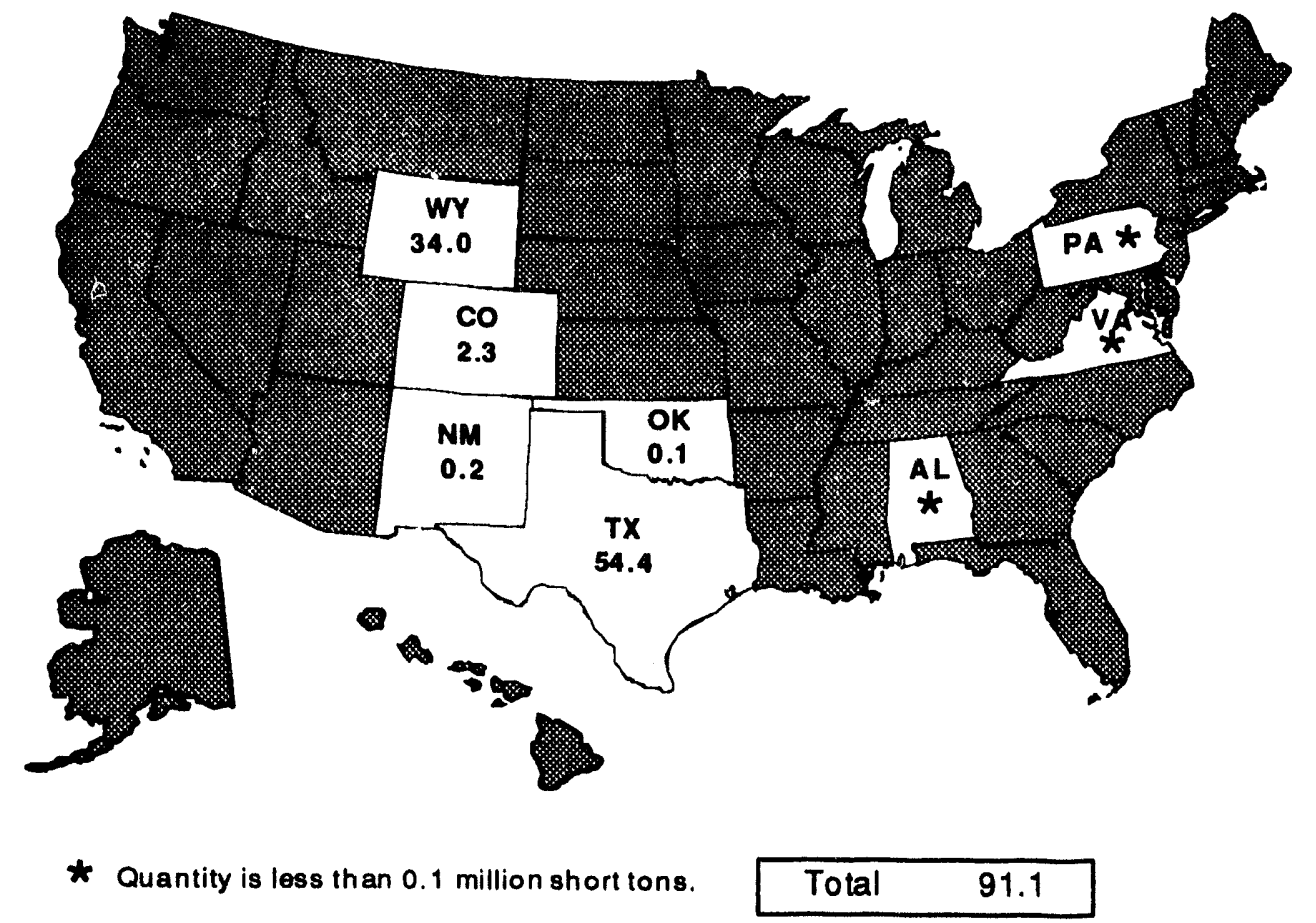

Note: Total may not equal sum of components because of independent rounding.

Source: Energy Information Administration, Form EIA-6, "Coal Distribution Report." 


\section{State Coal Profile: Utah}

Coal accounted for about 18 percent of the estimated value of mineral commodities produced in Utah in 1992. Royalties from coal production from Federal leases totaled $\$ 30$ million, which was disbursed to the State and the Federal Government.

Although coal deposits are widespread in Utah, production is currently from Wasatch Plateau, Book Cliffs, and Emery coalfields. These fields have sizable reserves of high-quality bituminous coal in relatively thick, continuous beds. Because the coalbeds in these fields generally occur near the base of high escarpments, mine entries are driven horizontally into the coalbeds. However, a few mines also have shafts to provide vertical access to the coal. Some coal in the Book Cliffs field has good coking properties and is used in blends to manufacture metallurgical coke. The leading sources of coal from the 10 coalbeds mined in 1992 were the Aberdeen, Hiawatha, and Blind Canyon, which range from 4 to 12 feet in thickness.

Coal was first mined in Utah in the early $1850^{\prime}$ s near what is now Cedar City, in the southwestern part of the State, for blacksmiths and settlements. The Coalville area in northern Utah became the State's major source of coal about 1870 with the opening of a mine to provide heating fuel for Salt Lake City. Coal development in the area was spurred by a $\$ 1,000$ reward offered in 1854 by the Territorial Legislature to the discoverer of a coal supply within $\mathbf{4 0}$ miles of Salt Lake City. Other coal deposits were developed later to supply fuel for the transcontinental railroad and branch railroads constructed in Utah and for manufacturing coke to smelt iron ore found in the State.

Utah's coal production reached 6 million short tons in 1920 under the stimulus of World War I and rising shipments of Utah coal to other States. In the 1930's, annual production decreased as markets were lost to competition from fuel oil and natural, $\mathrm{s}$ and the economic decline during the Depression. Production rose to more than 7 million short tons to meet the demands of World War II and the postwar boom. By the mid-1960's, however, Utah's annual coal output fell to about 4 million short tons, due mostly to the replacement of coal-burning locomotives with dieselpowered locomotives. Utah's coal production then became largely dependent on the demand for coking coal by the iron and steel industry. Utah's coal industry was revitalized in the 1970 's when the Arab oil embargo renewed interest in domestic coal as a source of utility fuel. As new mines were opened and existing mines expanded to supply coal mainly for new coalfired power plants constructed in Utah, the State's coal output trended sharply upward. Production was 21 million short tons in 1992.

Utah's coal is mined exclusively by underground methods. The State's largest coal mine in 1992, producing about 5 million short tons, was the Skyline mine of Coastal States Energy Company, in Carbon County. Carbon and Emery counties were the State's leading sources of coal. More than 80 percent of Utah's 1992 coal production was from Federal leases.

About 60 percent of the coal produced in Utah in 1992 was delivered to consumers in the State. Shipments out of State were chiefly to California and Nevada. Threefourths of the coal distributed went to power plants. The balance was mostly for industrial use, including coke production, and a small amount was exported overseas.

Power plants are by far the leading coal consumers in Utah, accounting for most of the 16 million short tons used in 1992. Utah's mines supplied the bulk of the utility coal required, with the balance received chiefly from Colorado. The largest generating facility is the 1,600-megawatt Intermountain power plant, operated by the City of Los Angeles, in Millard County. About half of the coking coal used in Utah was produced in the State, and the rest was from Pennsylvania, Virginia, and Colorado. Other users of industrial coal, all from Utah's mines, were mainly munufacturers of copper and cement. A small amount of fossil resin has been extracted intermittently since 1929 from coal from the Wasatach Plateau field. The resin is used to produce adhesives, rubber, paint, thermoplastics, and varnish for printing ink. 


\section{Utah}

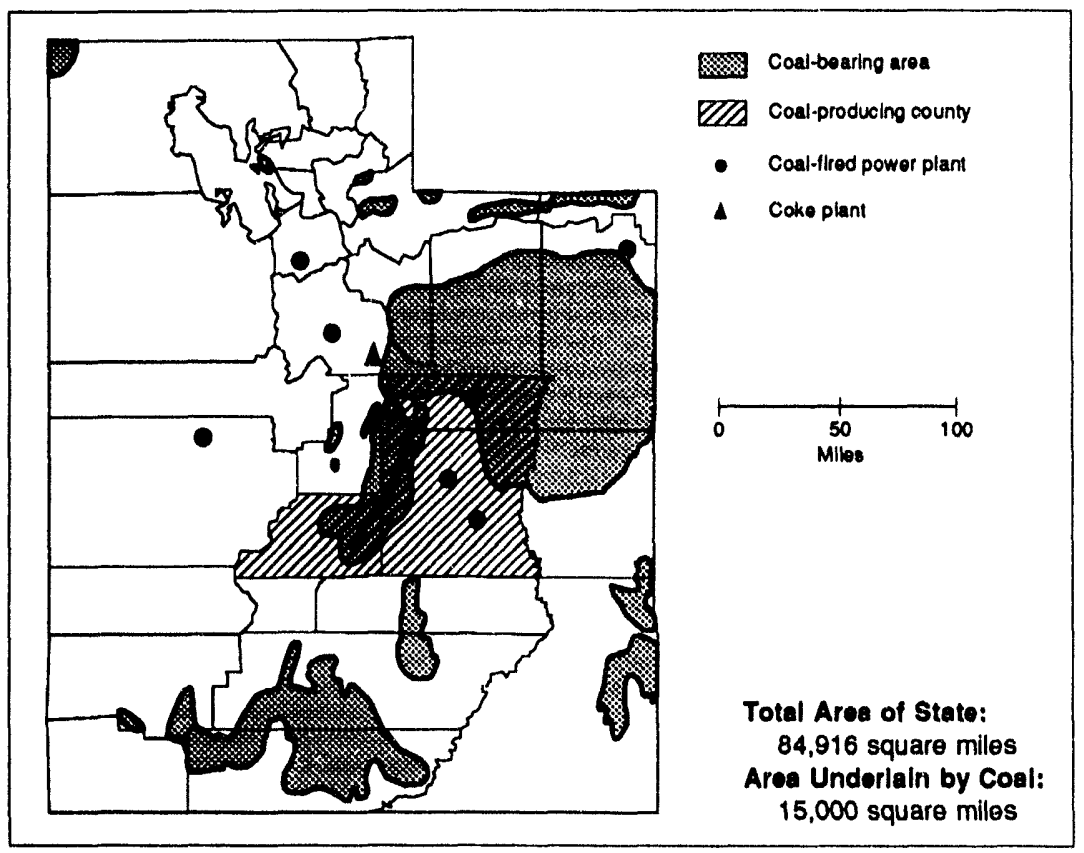

Coal Production, 1890-1992

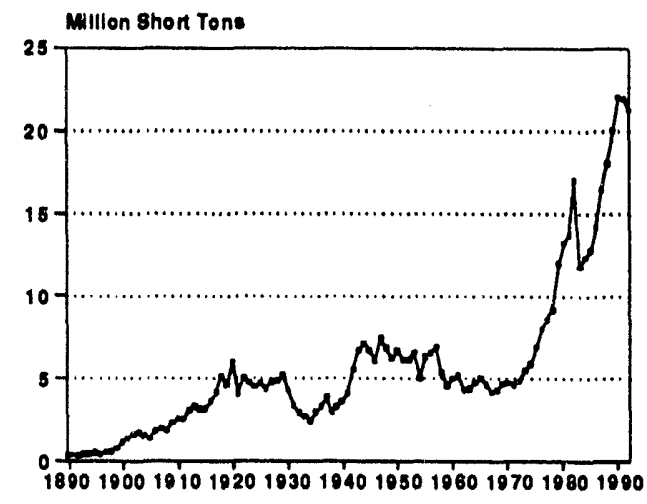

First Yoar of Documented Coal

Production . . . . . . . . . . . 1870 (5,800 short tons) Peak Year of Coal

Production. $1980(22,058,000$ short tons)

Coal Reserves (Million Short Tons)

\begin{tabular}{|c|c|c|c|}
\hline Type of Resorve & Underground & Surface & Total \\
\hline \multicolumn{4}{|l|}{ Domonstratod Reserve Base: } \\
\hline $\begin{array}{l}\text { (January 1, 1992) } \ldots \ldots \ldots \ldots \ldots \ldots \ldots \ldots \ldots \ldots \ldots \\
\text { Eetimated Recovorable Reserves: } \\
\text { (January 1, 1992) } \\
\text { Sulfur Content (pounds per million Btu) }\end{array}$ & 5,822 & 268 & 6,090 \\
\hline$<0.61$ (low sulfur) $\ldots \ldots \ldots \ldots \ldots \ldots \ldots \ldots$ & 1,040 & 40 & 1,081 \\
\hline $0.61-1.67$ (modium suifur) $\ldots \ldots \ldots \ldots \ldots \ldots \ldots$ & 1,346 & 103 & 1,449 \\
\hline$>1.67$ (high sulfur) $\ldots \ldots \ldots \ldots \ldots \ldots \ldots \ldots$ & 468 & 69 & 536 \\
\hline $\begin{array}{l}\text { Total } \ldots \ldots \ldots \ldots \ldots \ldots \ldots \ldots \ldots \ldots \ldots \ldots \ldots \\
\text { Eotlmated Rocoverable Resorves }\end{array}$ & 2,854 & 212 & 3,066 \\
\hline At Active Mince, Year-End $1982 \ldots \ldots$ & 488 & 0 & 488 \\
\hline
\end{tabular}

\section{Production}

\begin{tabular}{|c|c|c|c|c|c|}
\hline Sallent Data by Mine Type & 1980 & 1985 & 1990 & 1991 & 1892 \\
\hline \multicolumn{6}{|l|}{ Underground } \\
\hline Quantity (thousand short tons) $\ldots \ldots \ldots \ldots \ldots \ldots$ & 13,236 & $\$ 2,780$ & 22,058 & 21,945 & 21,339 \\
\hline Mines $\ldots \ldots \ldots \ldots \ldots \ldots \ldots \ldots \ldots \ldots \ldots$ & 29 & 22 & 18 & 15 & 15 \\
\hline 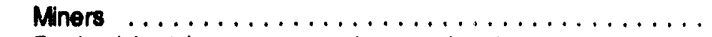 & 3,512 & 2,563 & 2,434 & 2,277 & 1,997 \\
\hline Productivity (short tons per miner per hour) $\ldots \ldots \ldots \ldots \ldots$ & 1.96 & 2.80 & 4.74 & 4.80 & 5.46 \\
\hline Average Mine Price (dollars per short ton) $\ldots \ldots \ldots \ldots \ldots$ & 25.63 & 27.68 & 18.53 & 22.59 & 21.11 \\
\hline \multicolumn{6}{|l|}{ Surtace } \\
\hline Quantity (thousand short tons) & 0 & 0 & 0 & 0 & 0 \\
\hline 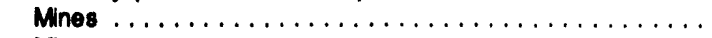 & 0 & 0 & 0 & 0 & 0 \\
\hline 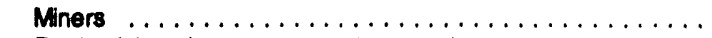 & 0 & 0 & 0 & 0 & 0 \\
\hline Productivity (shori tons per miner per hour) $\ldots \ldots \ldots \ldots$ & -. & $\cdots$ & $-\cdot$ & $\cdots$ & -. \\
\hline Average Mine Price (dollars per short ton) $\ldots \ldots \ldots \ldots$ & -- & $-\cdot$ & 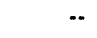 & $\cdots$ & 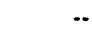 \\
\hline \multicolumn{6}{|l|}{ Total } \\
\hline Quantity (thousand short tons) & 13,236 & 12,780 & 22,058 & 21,945 & 21,338 \\
\hline Mines $\ldots \ldots \ldots \ldots \ldots \ldots \ldots \ldots \ldots \ldots \ldots \ldots$ & 29 & 22 & 18 & 15 & 15 \\
\hline 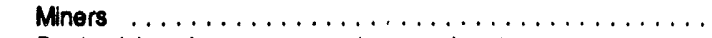 & 3,512 & 2,563 & 2,434 & 2,277 & 1,997 \\
\hline Productivity (short tons per miner per hour) . . . . . . . . . & 1.96 & 2.80 & 4.74 & 4.80 & 5.46 \\
\hline Average Mine Price (dollars per short ton) $\ldots \ldots \ldots \ldots \ldots$ & 25.63 & 27.69 & 18.53 & 22.59 & 21.11 \\
\hline
\end{tabular}




\section{Utah}

Number of Mines by Production Range and Percent of Production, 1992

\begin{tabular}{|c|c|c|c|c|c|c|c|c|}
\hline \multirow{3}{*}{ Mine Type } & \multicolumn{8}{|c|}{ Production Ranga (thousand short tons) } \\
\hline & \multicolumn{2}{|c|}{1,000 and over } & \multicolumn{2}{|c|}{500 to 999} & \multicolumn{2}{|c|}{10010499} & \multicolumn{2}{|c|}{$<100$} \\
\hline & Number & Percent & Number & Percont & Number & Percent & Number & Percent \\
\hline \multirow{3}{*}{ 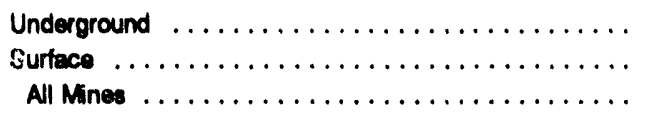 } & 6 & 84 & 2 & 7 & 7 & 9 & 0 & 0 \\
\hline & 0 & 0 & 0 & 0 & 0 & 0 & 0 & 0 \\
\hline & 6 & 84 & 2 & 7 & 7 & 9 & 0 & 0 \\
\hline Dlapoaition & 1980 & \multicolumn{2}{|c|}{1985} & 1990 & \multicolumn{2}{|r|}{1991} & \multicolumn{2}{|r|}{1922} \\
\hline \multicolumn{9}{|l|}{ Consumption (thousand short tons) } \\
\hline Electric Utillites $\ldots \ldots \ldots \ldots \ldots \ldots \ldots$ & 4,895 & \multicolumn{2}{|c|}{6,325} & \multicolumn{2}{|l|}{13,563} & 12,829 & \multicolumn{2}{|r|}{13,857} \\
\hline Coke Plante $\ldots \ldots \ldots \ldots \ldots \ldots \ldots$ & $w$ & \multicolumn{2}{|c|}{$w$} & \multicolumn{2}{|l|}{ w } & W & \multicolumn{2}{|r|}{$W$} \\
\hline Other Industrial $\ldots \ldots \ldots \ldots \ldots \ldots \ldots$ & 501 & \multicolumn{2}{|c|}{472} & \multicolumn{2}{|l|}{676} & 508 & \multicolumn{2}{|r|}{535} \\
\hline Residential and Commercial $\ldots \ldots \ldots \ldots$ & $w$ & \multicolumn{2}{|c|}{$w$} & \multicolumn{2}{|l|}{$w$} & $\mathbf{w}$ & \multicolumn{2}{|r|}{$w$} \\
\hline Total $\ldots \ldots \ldots \ldots \ldots \ldots \ldots \ldots \ldots$ & 7,108 & \multicolumn{2}{|c|}{8,303} & \multicolumn{2}{|l|}{15,738} & 14,834 & \multicolumn{2}{|r|}{15,729} \\
\hline \multicolumn{9}{|l|}{ Year-End Uillity Stocke } \\
\hline (thousand short tons) $\ldots \ldots \ldots \ldots \ldots$ & 1,092 & & 97 & 3,697 & & 4,123 & & 3,153 \\
\hline Electriclty Coneration & & & & & & & & \\
\hline Total (million kilowatthours) . . . . . . . . . . & 12,112 & & & 32,260 & & 30,158 & & 32,909 \\
\hline Coed (percent) $\ldots \ldots \ldots \ldots \ldots \ldots$ & 90 & & 92 & 98 & & 96 & & 96 \\
\hline Nudear (percent) & 0 & & 0 & 0 & & 0 & & 0 \\
\hline Other (percent) $\ldots \ldots \ldots \ldots \ldots \ldots \ldots$ & 10 & & 8 & 2 & & 4 & & 4 \\
\hline
\end{tabular}

\section{Utility Coal Data, 1992}

\begin{tabular}{|c|c|c|}
\hline Averege Cualliy and Average Delivered Coet & Produced in State & Recolpts, All Sources \\
\hline Heat Content (million Btu per short ton) . . . . . . . & 23.09 & 22.77 \\
\hline Sulfur Content (percent by weight) $\ldots \ldots \ldots \ldots \ldots \ldots \ldots \ldots$ & .46 & .47 \\
\hline Ash Content (percent by woight) $\ldots \ldots \ldots \ldots \ldots \ldots \ldots \ldots$ & 10.85 & 11.24 \\
\hline Pounds of Sulfur per million Btu $\ldots \ldots \ldots \ldots \ldots \ldots \ldots \ldots$ & .40 & .41 \\
\hline Dollars per million Btu $\ldots \ldots \ldots \ldots \ldots \ldots \ldots \ldots \ldots \ldots$ & 1.23 & 1.21 \\
\hline Dollars per short ton $\ldots \ldots \ldots \ldots \ldots \ldots \ldots \ldots \ldots \ldots$ & 28.31 & 27.54 \\
\hline
\end{tabular}

Eetimated Total State Energy Consumption, 1901: 566 trillion Btu (coal, 345; natural gas, 143; potroleum, 207; nuclear electrlc power, 0; hydroelectric power, 6; other, 4; net interctate flow of electriclity and associated losese, -138).

$W=$ Witheld to avoid disclosure of individual company data.

Noter: Totats may not equal sum of components because oi independent rounding. Dala coverage-production: all mines. Number of mines: 1980 , mines that produced 10,000 shoit tons or more; other years, all mines. Number of miners and productivity: mines that produced 10,000 or more short tons and preparation plants that had 5,000 or more employee hours. Average mine price: mines that produced 10,000 or more short tons. Average quality and average delivered coet of utility coal: power plants with a generator nameplate capacity of 50 megawatts or more. Extent of coal-bearing areas and locations of coalconsuming plants shown on map are approximate; small coal deposits are not shown. Coal-producing counties shown on map axclude any county where all 1992 output was from mines producing less than 10,000 short tons.

Sources: Energy Information Administration-U.S. Coal Reserves: An Update by Heat and Sultur Content, February 1993; Coal Production 1992 and prior issues; Coal Data: A Reference; Quantenty Coal Report October-December 1992 and prior issues; Electric Power Annual 1991 and prior issues; Electric Power Monthly, March 1993; Cost and Qualty of Fuels for Electric Power Plants 1892; Inventory of Power Plants in the United States 1992; State Energy Data Repon 1991: Consumption Estimates; Map of coal-bearing areas is based mainly on U.S. Geological Survey map, Coalfields of the United States, 1960. Data for historical graph 1890-1975, U.S. Department of the Interior, Geological Survey and Bureau of Mines (Minerals Yearbook and annual predecessor Mineral Resources of the United States); 1976 forward, Energy Information Administration, Coal Production 1992 and prior issues. 


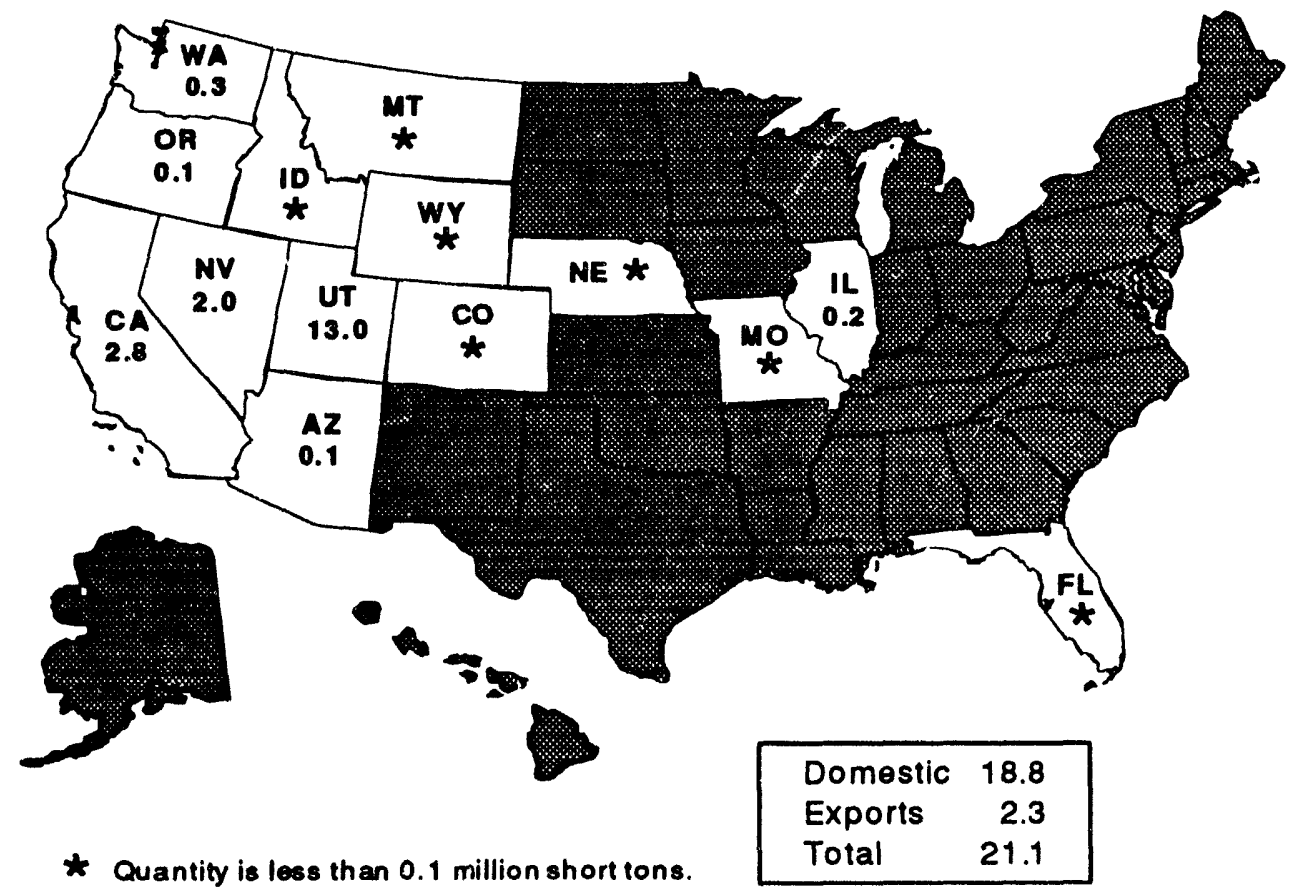

Transportation modes, domestic markets (percent): rail, 52; truck, 33; tramway/conveyor, 15; unknown, $<1$.

Note: Total may not equal sum of components because of independent rounding.

Source: Energy Information Administration, Form EIA-6, "Coal Distribution Report."

\section{Origin of Coal Recelved in Utah, 1992}

(Million Short Tons)

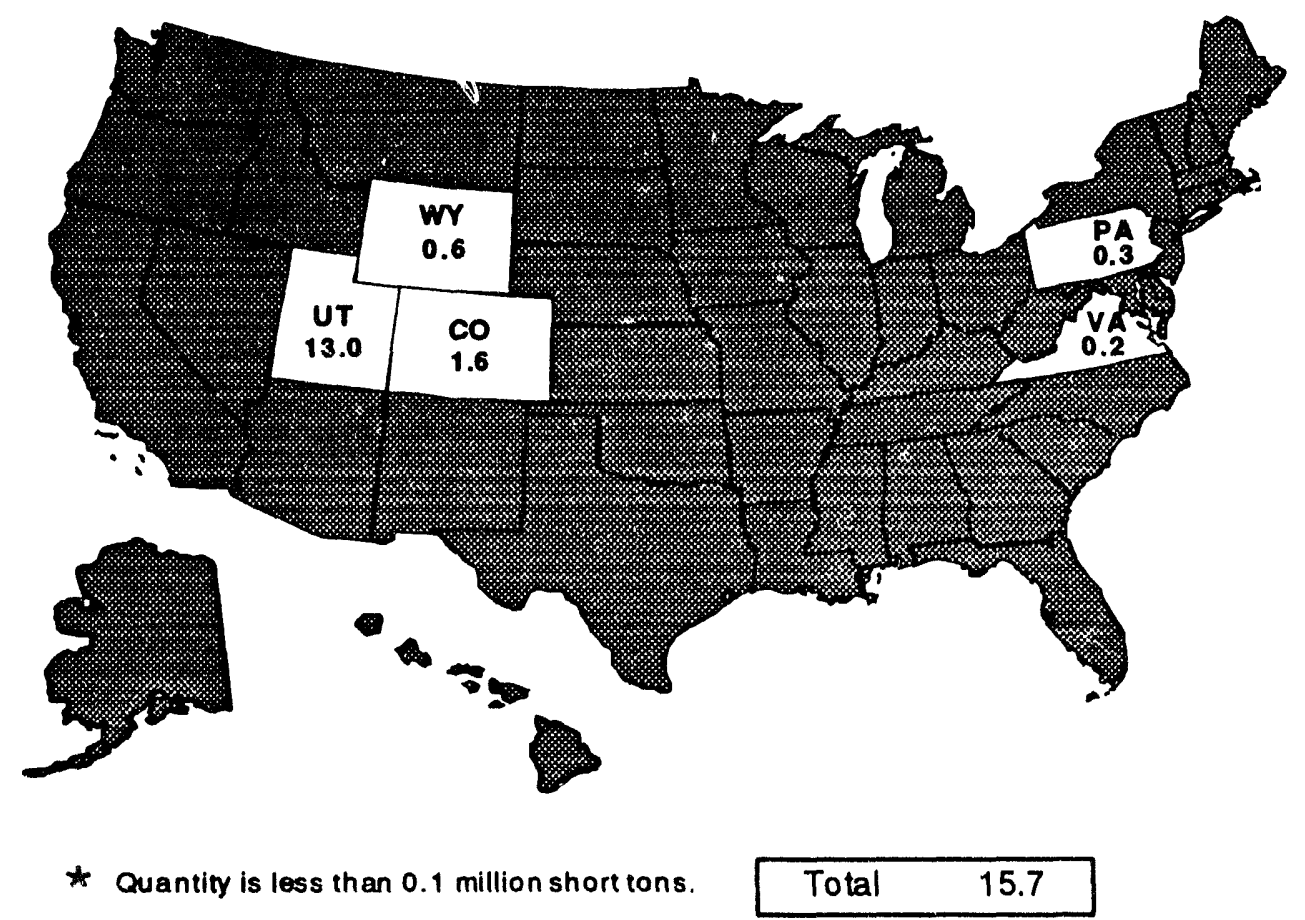

Note: Total may not equal sum of components because of independent rounding.

Source: Energy Information Administration, Form EIA-6, "Coal Distribution Report." 


\section{State Coal Profile: Virginia}

Coal is the most valuable of Virginia's mineral commodities. The 1992 coal production was estimated to account for more than two-thirds of the total value of all minerals produced in the State, including crude oil and natural gas.

Coal occurs in Virginia in three separate areas: the Eastern fields, consisting of two basins located west of Richmond; the Valley fields, comprising narrow coalbearing areas in the west-central part of the State; and the Southwest field, which is part of the Appalachian coal basin. The Southwest field contains most of Virginia's coal reserves and is the source of virtually all of the State's coal production.

Only bituminous coal is currently produced in Virginia, although semianthracite has been produced in the Valley fields. About half of Virginia's coal output is estimated to be metallurgical coal, used to make coke for the iron and steel industry in the United States and other countries. Although more than 40 coalbeds were mined in 1992, the leading sources of output were the Pocahontas No. 3 (an important source of metallurgical coal) and Jawbone. Coalbed thickness is 4 to 5 feet.

The first commercial production of coal in the United States began near Richmond in 1748. Consumers of this coal included local blacksmiths and iron foundries. After the Revolutionary War, production of Richmond coal rose to a peak of 175,000 short tons in 1835 and ended in the 1920's, due to competition from other coalfields. Production from the Valley coalfields trended upward in the late 1800 's after railroads were constructed to the mines. It reached more than 200,000 short tons annually in the 1930's and early 1940's before virtually ending in 1971. The Southwest coalfield became the center of Virginia's coal industry in the late 1800 's, when an extensive railroad system linked the area with coal consumers in Virginia and other States and to ports at Norfolk. Coke production began in the Southwest field in 1883.

Annual coal production in Virginia grew to 14 million short tons in 1926 and then dropped below ${ }^{r}$ million short tons during the Depression. It later recovured and reached 20 million short tons during World War II. In the decade following the war, the State's coal industry suffered losses as railroa is converted from coal to oil, and heating fuel markets switched to oil and natural gas. Production declined to a postwar low of about 16 million short tons in 1949 before recovering to trend generally upward to more than $\mathbf{4 0}$ million short tons in recent years. Initially, the increase was due largely to a growing demand for coking coal. Later, the upward trend was sustained by a rising demand for utility coal. Virginia's coal output was 43 million short tons in 1992.

Underground mines have always produced most of Virginia's coal. In recent years, they accounted for more than 80 percent of the State's total coal output. Surface coal mining in Virginia began in the 1920's and reached a peak in the mid 1970's. Virginia's largest mine, producing over 2 million short tons in 1992, was the underground Buchanan No. 1 mine of Consolidation Coal Company, in Buchanan County. The State's leading coal-producing counties were Buchanan and Wise.

Of the coal shipped from Virginia's mines in 1992, about 60 percent was for U.S. markets and the rest was exported. A little more than half of the out-of-State shipments was utility coal, delivered chiefly to power plants in North Carolina. Nearly one-third was coking coal for consumers mostly in Indiana and Pennsylvania.

More than 60 percent of the 13 million short tons of coal consumed in Virginia in 1992 was for generating electricity. About 40 percent of the utility coal was produced in Virginia, with nearly all of the balance received from Kentucky and West Virginia. Virginia's largest coal-fired generating utility is the 1,250megawatt Chesterfield plant of Virginia Electric and Power Company, in Chesterfield County. All of the coking coal used at the State's only coke plant, in Vansant, was from Virginia. Other industrial coal consumers in Virginia are manufacturers of paper, paperboard, and synthetic fibers. These consumers use coal from Virginia, West Virginia, and Kentucky.

In recent years, Virginia has ranked as the secondlargest coal exporting State, following West Virginia. About 90 percent of Virginia's coal exports were estimated to be metallurgical coal. Norfolk, Virginia, is the leading U.S. Customs District for coal exports, handling coal from Virginia and other States. The three coal-handling terminals are Lamberts Point Coal Pier No. 6, Dominion Terminals Associates, and Pier IX Terminal. In 1992, coal exports through the Norfolk Customs District totaled 53 million short tons, accounting for 52 percent of U.S. coal exports. 


\section{Virginia}

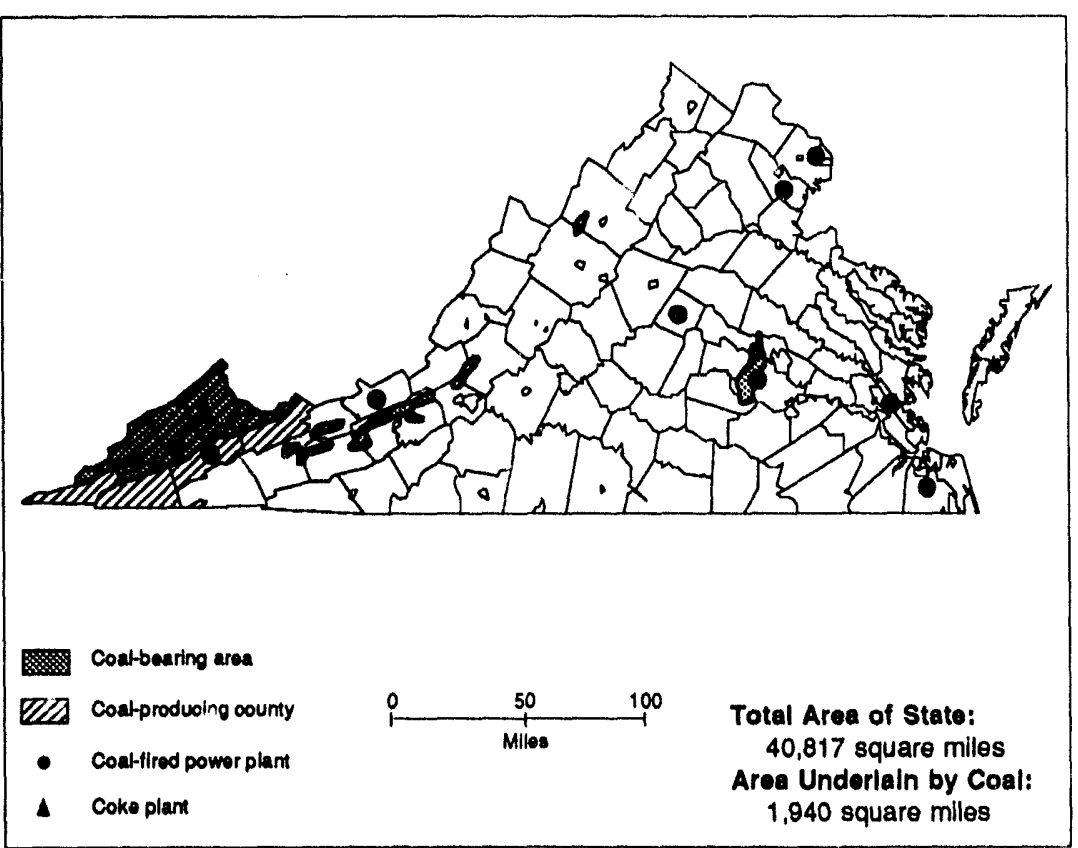

Coal Production, 1890-1992

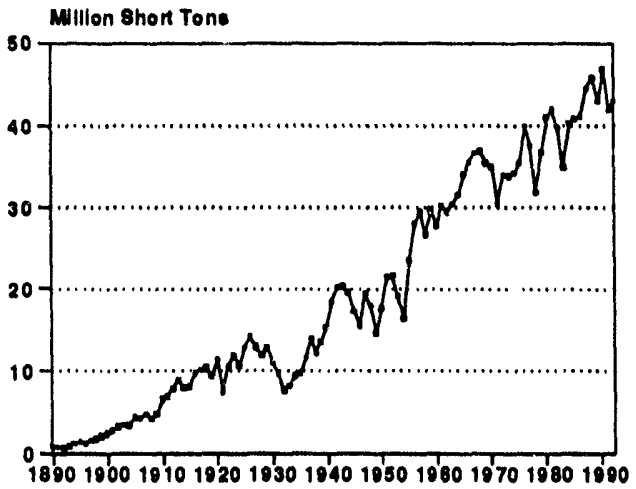

Firat Year of Documented Coal

Production . . . . . . . . . . . 1748 (50 shont tons) Peak Yoar of Coal

Production . . . . . . . . . 1990 (46,917,000 short tons)

\section{Coal Reserves (Million Short Tons)}

\begin{tabular}{|c|c|c|c|}
\hline Type of Reserve & Underground & Surface & Total \\
\hline 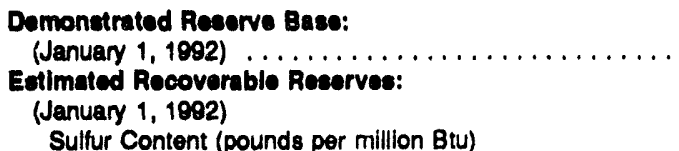 & 1,816 & 730 & 2,548 \\
\hline 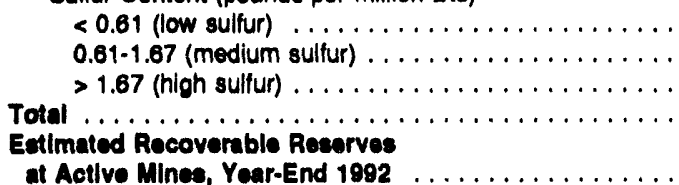 & $\begin{array}{r}654 \\
386 \\
0 \\
1,020\end{array}$ & $\begin{array}{r}252 \\
216 \\
0 \\
468\end{array}$ & $\begin{array}{r}905 \\
582 \\
0 \\
1,487\end{array}$ \\
\hline
\end{tabular}

\section{Production}

\begin{tabular}{|c|c|c|c|c|c|}
\hline Sallone Data by Mino Typo & 1980 & 1985 & 1990 & 1991 & 1982 \\
\hline \multicolumn{6}{|l|}{ Undorground } \\
\hline $\begin{array}{l}\text { Quantity (thousand short tons) } \ldots \ldots \ldots \ldots \ldots \ldots \ldots \ldots \ldots \\
\text { Mines } \ldots \ldots \ldots \ldots \ldots \ldots \ldots \ldots \ldots \ldots \\
\text { Miners } \ldots \ldots \ldots \ldots \ldots \ldots \ldots \ldots \ldots \ldots \\
\text { Productivity (short tons per miner per hour) } \ldots \ldots \ldots \ldots \ldots \\
\text { Average Mine Price (dollars per short ton) } \ldots \ldots \ldots \ldots \ldots \ldots\end{array}$ & $\begin{array}{r}32,358 \\
387 \\
13,569 \\
1.27 \\
36.47\end{array}$ & $\begin{array}{r}33,550 \\
390 \\
11,553 \\
1.72 \\
30.37\end{array}$ & $\begin{array}{r}39,150 \\
258 \\
8,955 \\
2.14 \\
28.39\end{array}$ & $\begin{array}{r}34,138 \\
222 \\
8,515 \\
2.12 \\
27.76\end{array}$ & $\begin{array}{r}34,715 \\
196 \\
7,888 \\
2.20 \\
27.88\end{array}$ \\
\hline \multicolumn{6}{|l|}{ surtace } \\
\hline $\begin{array}{l}\text { Quantity (thousand short tons) } \ldots \ldots \ldots \ldots \ldots \ldots \ldots \ldots \ldots \\
\text { Mines } \ldots \ldots \ldots \ldots \ldots \ldots \ldots \ldots \ldots \ldots \ldots \\
\text { Miners } \ldots \ldots \ldots \ldots \ldots \ldots \ldots \ldots \ldots \ldots \ldots \\
\text { Productivity (short tons per miner per hour) } \ldots \ldots \ldots \ldots \ldots \ldots \\
\text { Average Mine Price (dollars per short ton) } \ldots \ldots \ldots \ldots \ldots \ldots\end{array}$ & $\begin{array}{r}8,651 \\
115 \\
2,307 \\
1.91 \\
28.05\end{array}$ & $\begin{array}{r}7,390 \\
119 \\
1,715 \\
2.37 \\
29.18\end{array}$ & $\begin{array}{r}7,767 \\
82 \\
1,387 \\
2.89 \\
26.32\end{array}$ & $\begin{array}{r}7,816 \\
72 \\
1,540 \\
2.95 \\
26.12\end{array}$ & $\begin{array}{r}8,308 \\
62 \\
1,250 \\
3.50 \\
26.17\end{array}$ \\
\hline \multicolumn{6}{|l|}{ Total } \\
\hline $\begin{array}{l}\text { Quantity (thousand short tons) } \\
\text { Mines } \ldots \ldots \ldots \ldots \ldots \ldots \ldots \ldots \ldots \ldots \ldots \ldots \ldots \ldots \ldots \ldots \ldots \ldots \ldots \ldots \\
\text { Miners } \ldots \ldots \ldots \ldots \ldots \ldots \ldots \ldots \\
\text { Productlvity (short tons per miner per hour) } \ldots \ldots \ldots \ldots \ldots \\
\text { Average Mine Price (dollars per short ton) } \ldots \ldots \ldots \ldots \ldots \ldots\end{array}$ & $\begin{array}{r}41,009 \\
502 \\
15,876 \\
1.37 \\
34.58\end{array}$ & $\begin{array}{r}40,940 \\
509 \\
13,268 \\
1.81 \\
30.16\end{array}$ & $\begin{array}{r}46,917 \\
340 \\
10,342 \\
2.24 \\
28.05\end{array}$ & $\begin{array}{r}41,954 \\
294 \\
10,055 \\
2.23 \\
27.45\end{array}$ & $\begin{array}{r}43,024 \\
258 \\
9,138 \\
2.37 \\
27.55\end{array}$ \\
\hline
\end{tabular}




\section{Virginia}

Number of Mines by Production Range and Percemt of Production, 1992

\begin{tabular}{|c|c|c|c|c|c|c|c|c|}
\hline \multirow{3}{*}{ Mine Type } & \multicolumn{8}{|c|}{ Production Range (thousand short tons) } \\
\hline & \multicolumn{2}{|c|}{1,000 and over } & \multicolumn{2}{|c|}{500 to 999} & \multicolumn{2}{|c|}{100 to 499} & \multicolumn{2}{|c|}{$<100$} \\
\hline & Number & Percent & Number & Percent & Number & Percent & Number & Percent \\
\hline Underground & 7 & 32 & 5 & 9 & 72 & 45 & 112 & 14 \\
\hline$\ldots \ldots \ldots \ldots$ & 0 & 0 & 1 & 7 & 28 & 80 & 35 & 13 \\
\hline All Mines $\ldots \ldots \ldots \ldots \ldots \ldots \ldots \ldots \ldots \ldots$ & 7 & 28 & 6 & 9 & 98 & 52 & 147 & 13 \\
\hline
\end{tabular}

\section{Coal Demand}

\begin{tabular}{|c|c|c|c|c|c|}
\hline Dleposition & 1980 & 1085 & 1900 & 1991 & 1902 \\
\hline \multicolumn{6}{|l|}{ Coneumptlon (thousand short tons) } \\
\hline Electric Utlities . . . . . . . . . . . . & 5,560 & 7,166 & 8,228 & 8,568 & 8,839 \\
\hline Coke Plants . . . . . . . . . . . . . & $\mathbf{W}$ & W & w & W & W \\
\hline Other Industrial $\ldots \ldots \ldots \ldots \ldots \ldots$ & 2,875 & 3,334 & 3,756 & 4,301 & 3,594 \\
\hline Residential and Commercial $\ldots \ldots \ldots$ & W & W & $w$ & $w$ & W \\
\hline Total $\ldots \ldots \ldots \ldots \ldots \ldots \ldots \ldots$ & 9,291 & 11,656 & 13,105 & 13,980 & 13,397 \\
\hline \multicolumn{6}{|l|}{ Year-End Uility Stocke } \\
\hline (thousand short tons) $\ldots \ldots \ldots \ldots \ldots$ & 1,251 & 1,682 & 1,639 & 1,685 & 1,922 \\
\hline \multicolumn{6}{|l|}{ Electriclty Qeneration } \\
\hline Total (million kilowatthours) . . . . . . . . & 34,306 & 42,084 & 47,200 & 48,841 & 48,910 \\
\hline Coal (percent) $\ldots \ldots \ldots \ldots \ldots \ldots$ & 39 & 42 & 44 & 45 & 46 \\
\hline Nuclear (percent) $\ldots \ldots \ldots \ldots \ldots$ & 33 & 53 & 50 & 49 & 48 \\
\hline Other (percent) $\ldots \ldots \ldots \ldots \ldots \ldots$ & 28 & 5 & 6 & 6 & 6 \\
\hline
\end{tabular}

\section{Utility Coal Data, 1992}

\begin{tabular}{|c|c|c|}
\hline Average Qualty and Average Delivered Cost & Produced In stato & Aeceipts, All Sources \\
\hline Heat Content (million Btu per short ton) & 25.74 & 25.66 \\
\hline Sulfur Content (percent by weight) $\ldots \ldots \ldots \ldots \ldots \ldots \ldots$ & 1.10 & 1.03 \\
\hline Ash Content (percent by weight) $\ldots \ldots \ldots \ldots \ldots \ldots \ldots$ & 9.67 & 9.48 \\
\hline Pounds of Sulfur per miltion Btu $\ldots \ldots \ldots \ldots \ldots \ldots \ldots$ & .85 & .80 \\
\hline Dollars per million Btu $\ldots \ldots \ldots \ldots \ldots \ldots \ldots \ldots \ldots$ & 1.64 & 1.47 \\
\hline Dollars per shon ton $\ldots \ldots \ldots \ldots \ldots \ldots \ldots \ldots \ldots \ldots \ldots \ldots \ldots$ & 42.21 & 37.81 \\
\hline
\end{tabular}

Estimated Total State Energy Coneumption, 1991: 1,848 trillion Btu (coal, 357; natural gas, 182; petroleum, 744; nuclear electric power, 257; hydroelectric power, <1; othor, <1; not interstute how of electricity and associated losess, 309).

W $=$ Witheid to avoid disclosure of individual company data.

Notes: Totals may not squal eum of components becaues of indopendent rounding. Data coverage-Productlon: all mines. Number of mines: 1980 , mines that produced 10,000 short tons or more; other years, all mines. Number of miners and productivity: mines that produced 10,000 or more short tons and preparation plants that had 5,000 or more employee hours. Average mine price: mines that produced 10,000 or more short tons. Average quality and average dellvered coet of utilly coal: power plants with a generator nameplate capacity of 50 megawatts or more. Extent of coal-bearing areas and locations of coal-consuming plants shown on map are approximate; small coal deposits are not shown. Coal-producing counties shown on map exclude any county where all 1992 output was from mines producing less than 10,000 short tons.

Sources: Energy information Administration-U.S. Coal Reserves: An Update by Heat and Sulfur Content, February 1993; Coal Production 1992 and prior issues; Coal Data: A Reference; Quanterly Coal Report October-December 1992 and prior issues; Electric Power Annual 1991 and prior issues; Electric Power Monthly, March 1993; Cost and Quality of Fuels for Electric Power Plants 1992; Inventory of Power Plants in the United States 1992; State Energy Data Report 1991: Consumption Estimates; Map of coal-bearing areas is based mainly on U.S. Geological Surve) map, Coalfields of the United States, 1960. Data for historical graph 1890-1975, U.S. Department of the Interior, Geological Survey and Bureau of Mines iMinerals Yearbook and annual predecessor Mineral Resources of the United States); 1976 forward, Energy Information Administration, Coal Production 1992 and prior issues. 


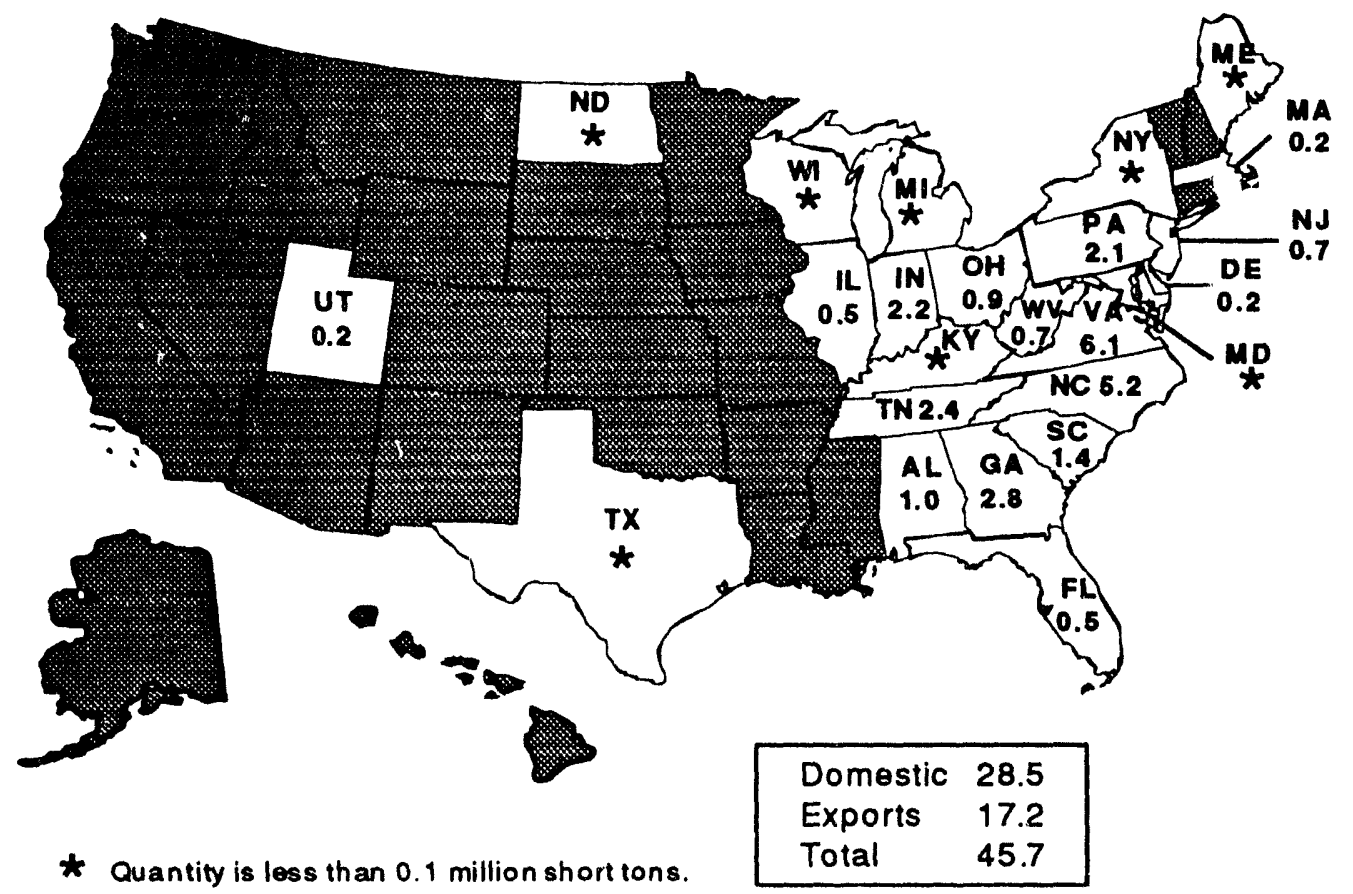

Transportation modes, domestic markets (percent): rail, 78; water, 13; truck, 1; tramway/conveyor, 3; unknown, 4.

Note: Total may not equal sum of components because of independent rounding.

Source: Energy Information Administration, Form EIA-6, "Coal Distribution Report."

\section{Origin of Coal Recelved In Virginla, 1992} (Million Short Tons)

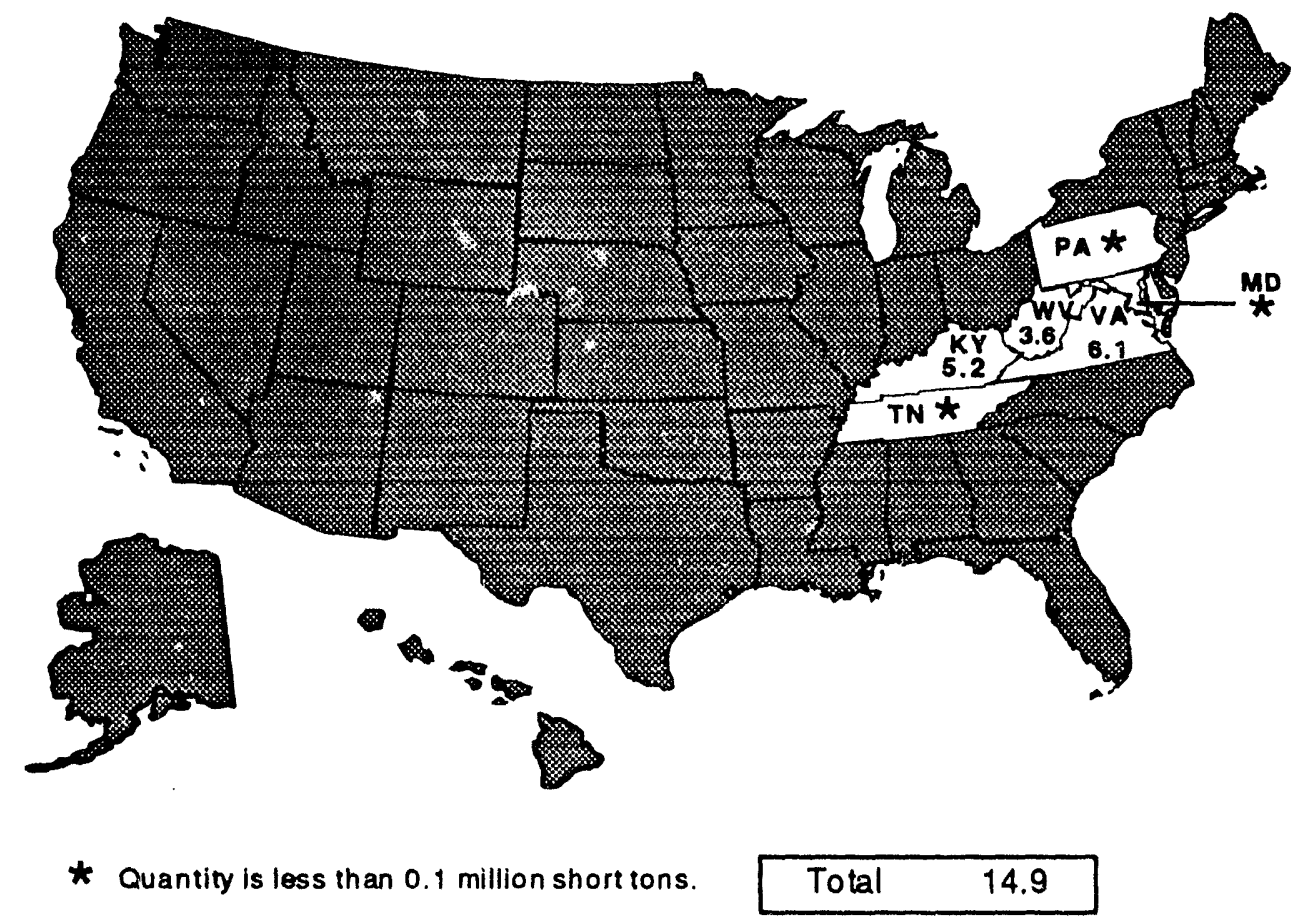

Note: Total may not equal sum of components because of independent rounding.

Source: Energy Information Administration, Form EIA-6, "Coal Distribution Report." 


\section{State Coal Profile: Washington}

Coal is an inportant part of the mineral economy of Washingtor. In 1992, coal was estimated to be the second-highest valued mineral commodity produced in the State, after sand and gravel, accounting for nearly one-fifth of the estimated value of all mineral commodities produced. A Federal coal lease generated \$2 million in royalties, which were disbursed to the State and the Federal Government. Although coal is the only mineral fuel produced in Washington, its role as an energy source is greatly overshadowed by the abundance of hydroelectric power in the State.

The principal coal deposits in Washington occur in small areas in the western half of the State. The major economic coal deposits are located along the western slope of the Cascade Mountains. All ranks of coal, from lignite to anthracite, are present in Washington, but production consists predominantly of subbituminous coal, with a small amount of bituminous coal. Although some Washington coal is suitable for conversion to coke for metallurgical use, none has been mined for this purpose since World War II.

The coalbeds in Washington are commonly folded and faulted, features that hamper mining. Only a few areas are suitable for surface mining. The high ash content characteristic of many coalbeds in the State is due to volcanic ash that fell when the coal-forming plant material was deposited. Production in 1992 was from about eight coalbeds ranging from 8 to 50 feet in thickness. The major bed is the Big Seam, which averages about 26 feet in thickness.

The earliest recorded discovery of coal in Washington was in 1833, along the Toutle River in what is now Cowlitz County. The State's first coal mine was opened in 1853 near Bellingham, Whatcom County. Soon after, mining began in other areas, and by 1880 all of the State's major coal deposits were being produced. Totaling 2 million short tons in 1900, production doubled by 1918, reflecting an increase in derrand created by World War I. Early coal consumers in the State included railroads, electric utilities, cement mills, coke plants, briquette producers, smelters, and manufactured gas plants. Coal was also shipped to California.

After World War I, annual coal production trended downward as consumers switched to oil or turned to less expensive coal from Utah and Wyoming. In the 1930 's, the coal industry suffered as the State's large hydroelectric resources were developed to provide lowcost electricity. Coal production dropped below 2 million short tons in the $1930^{\prime} \mathrm{s}$ and fell to 37,000 short tons by 1970 .

Interest in Washington's coal was renewed in the 1960's when projections of future electricity requirements escalated beyond the capability of the State's hydroelectric plants. This led to the opening of the Centralia surface coal mine, in Lewis and Thurston counties, to produce subbituminous coal for the Centralia power plant of PacifiCorp, constructed near the mine in Lewis County. In 1971, when the plant's first electric generating unit was placed in service, coal output rose above 1 million short tons. The following year, it more than doubled to fuel a second generating unit at the plant, which has a total generating capability of 1,310 megawatts. Since then, annual production has ranged from 4 to 5 million short tons; in 1992, nearly one-third of the mine's output was from a Federal coal lease. A subsidiary of PacifiCorp operates the mine.

Although the Centralia mine accounts for most of Washington's coal output, a smaller coal mine has been in operation since 1986. This is the John Henry No. 1 surface mine of Pacific Coal Coast Company, located about 50 miles northeast of Centralia, in King County. The mine's production, all bituminous coal, totaled about 300,000 short tons in 1992. About three-fourths of the output was exported to Japan and Korea. The export coal was carried by rail to Westshore Terminals at the Port of Vancouver, Canada, for loading into colliers. The balance of the mine's output was used in Washington.

Virtually all of the 6 million short tons of coal consumed in Washington in 1992 was for generating electricity. Nearly all of the utility coal used was from the Centralia mine, with a smaller amount from the John Henry No. 1 mine. Supplementing this supply was coal from Montana and Utah. Of the coal used for other purposes, nearly two-thirds was from Utah, with the balance mostly irom Washington and Colorado. The principal industrial users of coal in Washington were manufacturers of cement, pulp, and nonmetallic products. 


\section{Washington}

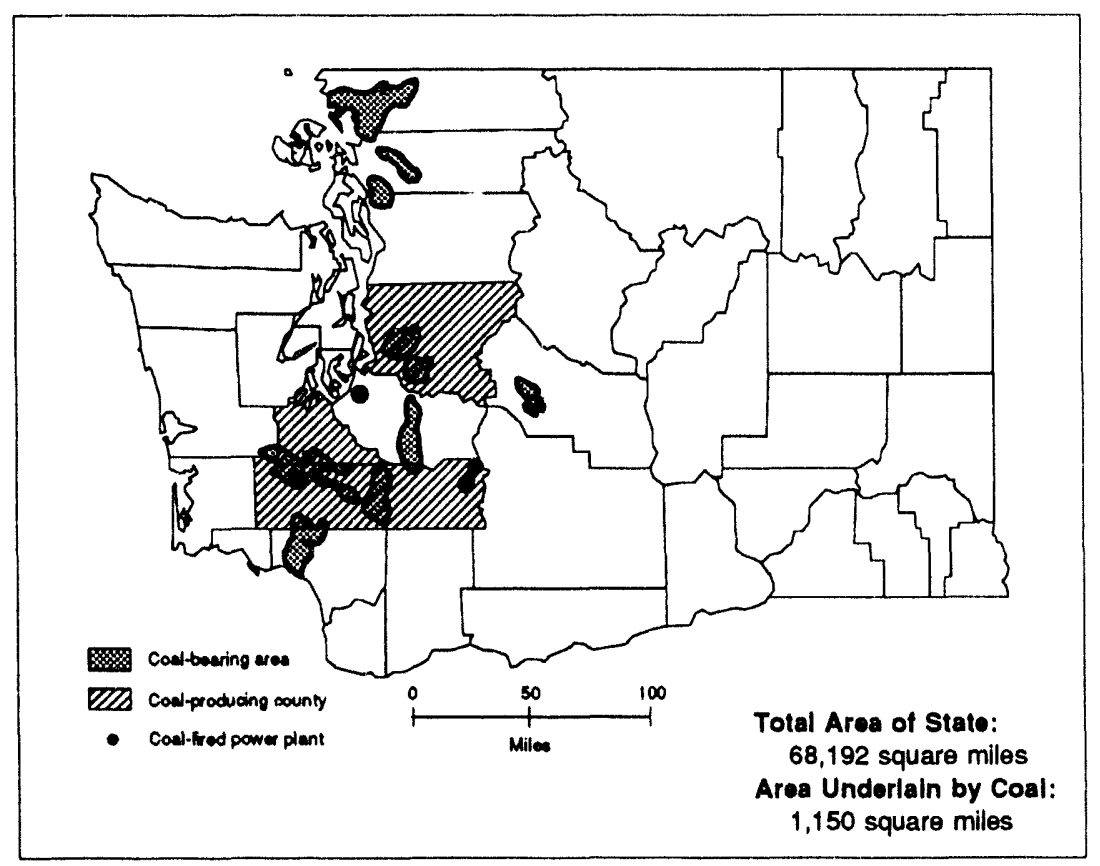

Coal Production, 1890-1992

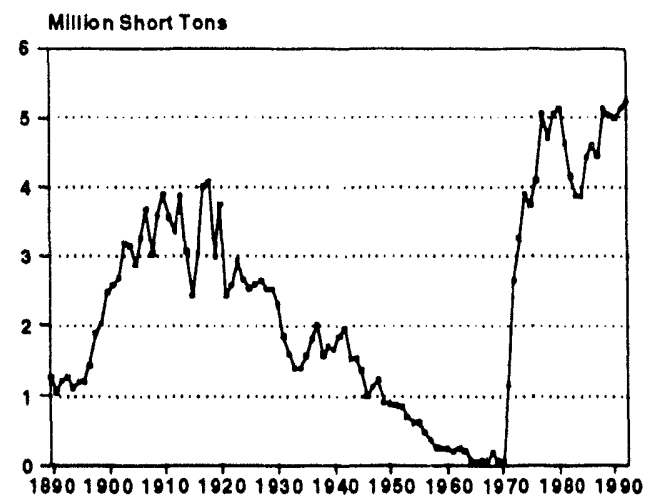

First Year of Documented Coal

Production . . . . . . . . . . 1860 (5,374 short tons) Peak Year of Coal

Production . . . . . . . . 1992 (5,251,000 short tons)

Coal Reserves (Million Short Tons)

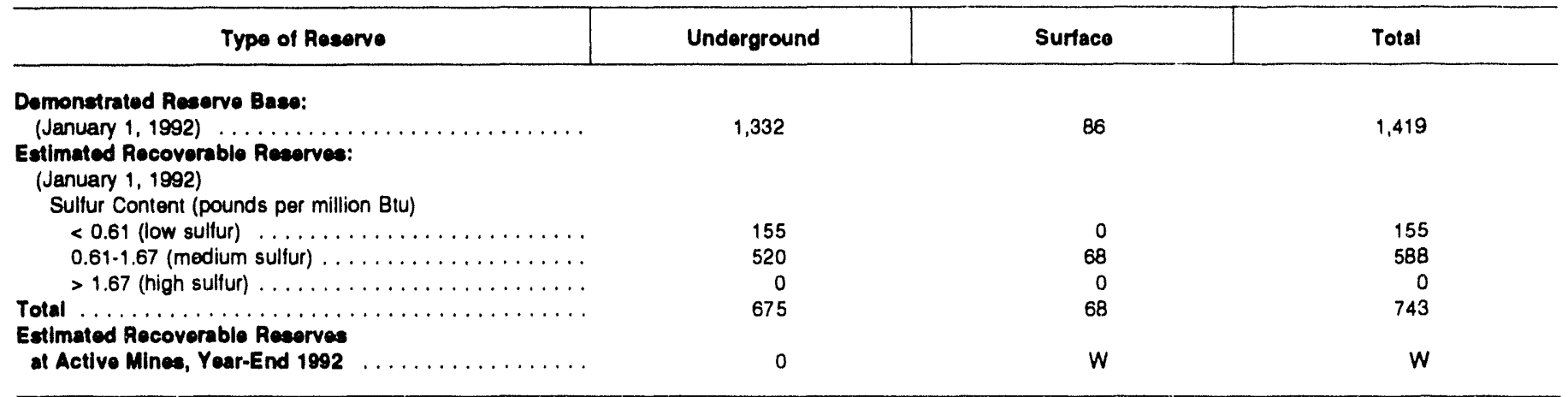

\section{Production}

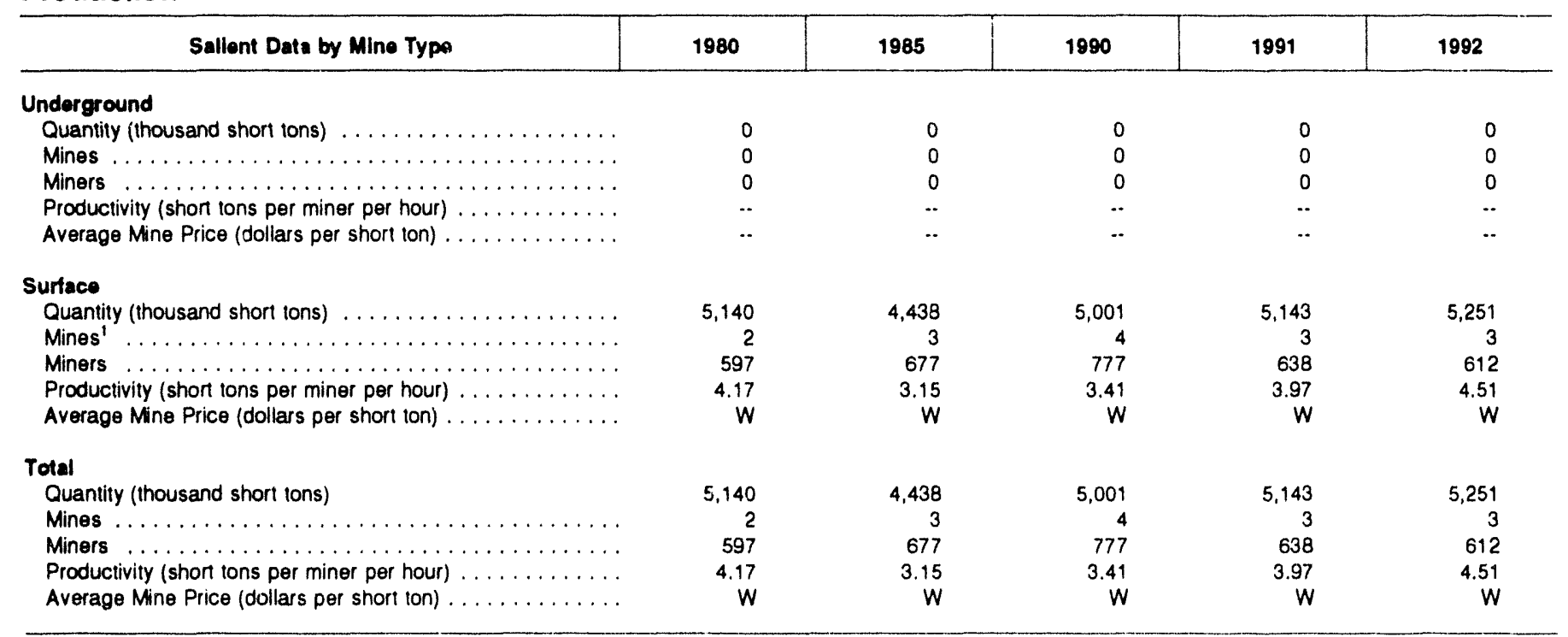




\section{Washington}

Number of Mines by Production Range and Percent of Production, 1992

\begin{tabular}{|c|c|c|c|c|c|c|c|c|}
\hline \multirow{3}{*}{ Mine Type } & \multicolumn{8}{|c|}{ Production Range (thousand short tons) } \\
\hline & \multicolumn{2}{|c|}{1,000 and over } & \multicolumn{2}{|c|}{500 to 999} & \multicolumn{2}{|c|}{10010499} & \multicolumn{2}{|c|}{$<100$} \\
\hline & Number & Percent & Number & Percont & Number & Percent & Number & Percent \\
\hline Underground & 0 & 0 & 0 & 0 & 0 & 0 & 0 & 0 \\
\hline Surfacs' ${ }^{1} \ldots$ & 2 & 94 & 0 & 0 & 1 & 6 & 0 & 0 \\
\hline All Mines' & 2 & 94 & 0 & 0 & 1 & 6 & 0 & 0 \\
\hline
\end{tabular}

Coal Demand

\begin{tabular}{|c|c|c|c|c|c|}
\hline Dleposition & 1080 & 1985 & 1900 & 1901 & 1092 \\
\hline \multicolumn{6}{|l|}{ Consumption (thousand short tons) } \\
\hline Electric Utilities $\ldots \ldots \ldots \ldots \ldots \ldots \ldots$ & 4,950 & 5,192 & 4,852 & 5,184 & 6,148 \\
\hline Coke Plants $\ldots \ldots \ldots \ldots \ldots \ldots \ldots$ & 0 & 0 & 0 & 0 & 0 \\
\hline Other Industrial $\ldots \ldots \ldots \ldots \ldots \ldots \ldots \ldots$ & 332 & 208 & 229 & 197 & 194 \\
\hline Residential and Commercial $\ldots \ldots \ldots \ldots$ & 161 & 216 & 66 & 80 & 91 \\
\hline Total $\ldots \ldots \ldots \ldots \ldots \ldots \ldots \ldots$ & 5,443 & 5,616 & 5,147 & 5,461 & 6,433 \\
\hline \multicolumn{6}{|l|}{ Year-End Utility Stocks } \\
\hline (thousand short tons) $\ldots \ldots \ldots \ldots \ldots \ldots$ & 1,704 & 378 & 1,316 & 1,145 & 697 \\
\hline \multicolumn{6}{|l|}{ Electricity Ceneration } \\
\hline Total (million kilowatthours) $\ldots \ldots \ldots \ldots$ & 92,325 & 93,140 & 100,479 & 101,353 & 84.112 \\
\hline Coal (percent) $\ldots \ldots \ldots \ldots \ldots \ldots \ldots$ & 8 & 8 & 7 & 8 & 11 \\
\hline Nuclear (percent) $\ldots \ldots \ldots \ldots \ldots \ldots$ & 2 & 9 & 6 & 4 & 7 \\
\hline Other (percent) $\ldots \ldots \ldots \ldots \ldots \ldots \ldots$ & 90 & 83 & 87 & 88 & 82 \\
\hline
\end{tabular}

\section{Utility Coal Data, 1992}

\begin{tabular}{|c|c|c|}
\hline Averege Quallty and Average Dellvered Coet & Produced in State & Recolpte, All Sources \\
\hline Heat Content (million Btu per short ton) $\ldots \ldots \ldots \ldots \ldots \ldots \ldots$ & 15.84 & 16.38 \\
\hline Sulfur Content (percent by weight) $\ldots \ldots \ldots \ldots \ldots \ldots \ldots \ldots$ & .70 & .66 \\
\hline Ash Content (percent by woight) $\ldots \ldots \ldots \ldots \ldots \ldots \ldots \ldots$ & 15.16 & 13.69 \\
\hline Pounds of Sulfur per million Btu $\ldots \ldots \ldots \ldots \ldots \ldots \ldots \ldots$ & .88 & .81 \\
\hline Dollars per million Btu $\ldots \ldots \ldots \ldots \ldots \ldots \ldots \ldots \ldots \ldots$ & 1.40 & 1.37 \\
\hline Dollars per shor ton $\ldots \ldots \ldots \ldots \ldots \ldots \ldots \ldots \ldots \ldots \ldots \ldots \ldots$ & 22.12 & 22.48 \\
\hline
\end{tabular}

Eatimated Total State Energy Coneur . Ion, 1901: 1,965 trillion Btu (coal, 89; natural gae, 178; potroloum, 776; nuclear electric power, 45; hydroelectrlc power, 908; other, 3; net interstate fluw of electricity and aseociated loseses, -34 ).

\footnotetext{
'Includes one mine operating in two counties and counted as two mines.

$W=$ Withheld to avoid disclosure of individual company data.

Notes: Totals may not equal sum of components because of independent rounding. Data coverage-Production: all mines. Number of mines: 1980, mines that produced 10,000 short lons or more; other years, all mines. Number of miners and productivity: mines that produced 10,000 or more short tons and preparation plants that had 5,000 or more employee hours. Average mine price: mines that produced 10,000 or more short tons. Average quality and average delivered cost of utility conl: power plants with a generator nameplate capacity of 50 megawatts or more. Extent of coal-bearing areas and locations of coalconsuming plants shown on map are approximate; small coal deposits are not shown. Coal-producing counties shown on map exclude any county where all 1992 output was from mines producing less than 10,000 short tons.

Sources: Energy Information Administration-U.S. Coal Reserves: An Update by Heat and Sulfur Content, February 1993; Coal Production 1992 and prior issues; Coal Data: A Reference; Quarterly Coal Report October-December 1992 and prior issues; Electric Power Annual 1991 and prior issues; Electric Power Monthly, March 1993; Cost and Quality of Fuels for Electric Power Plants 1992; Inventory of Power Plants in the United States 1992; State Energy Data Report 1991: Consumption Estimates; Map of coal-bearing areas is based mainly on U.S. Geological Survey map, Coalfields of the United States, 1960. Data for historical graph 1890-1975, U.S. Department of the Interior, Geological Survey and Bureau of Mines (Minerals Yearbook and annual predecessor Mineral Resources of the United States); 1976 forward, Energy Information Administration, Coal Production 1992 and prior issues.
} 
Destination of Coal Produced in Washington, 1992

(Million Short Tons)

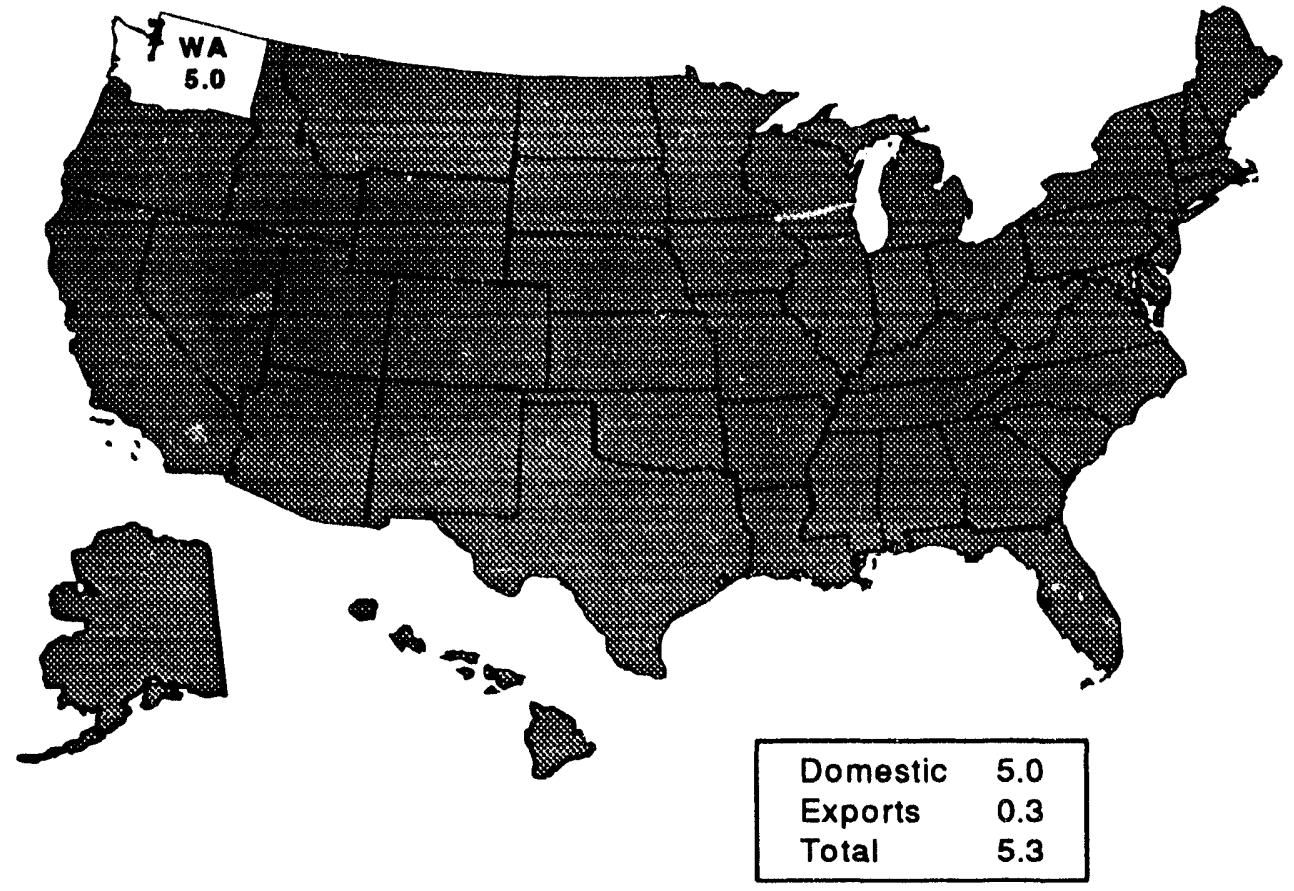

Transportation modes, domestic markets (percent): rail, $<1$; truck, $<1$; tramway/conveyor, 98.

Note: Total may not equal sum of components because of independent rounding.

Source: Energy Information Administration, Form EIA-6, "Coal Distribution Report."

Origin of Coal Recelved In Washington, 1992

(Million Short Tons)

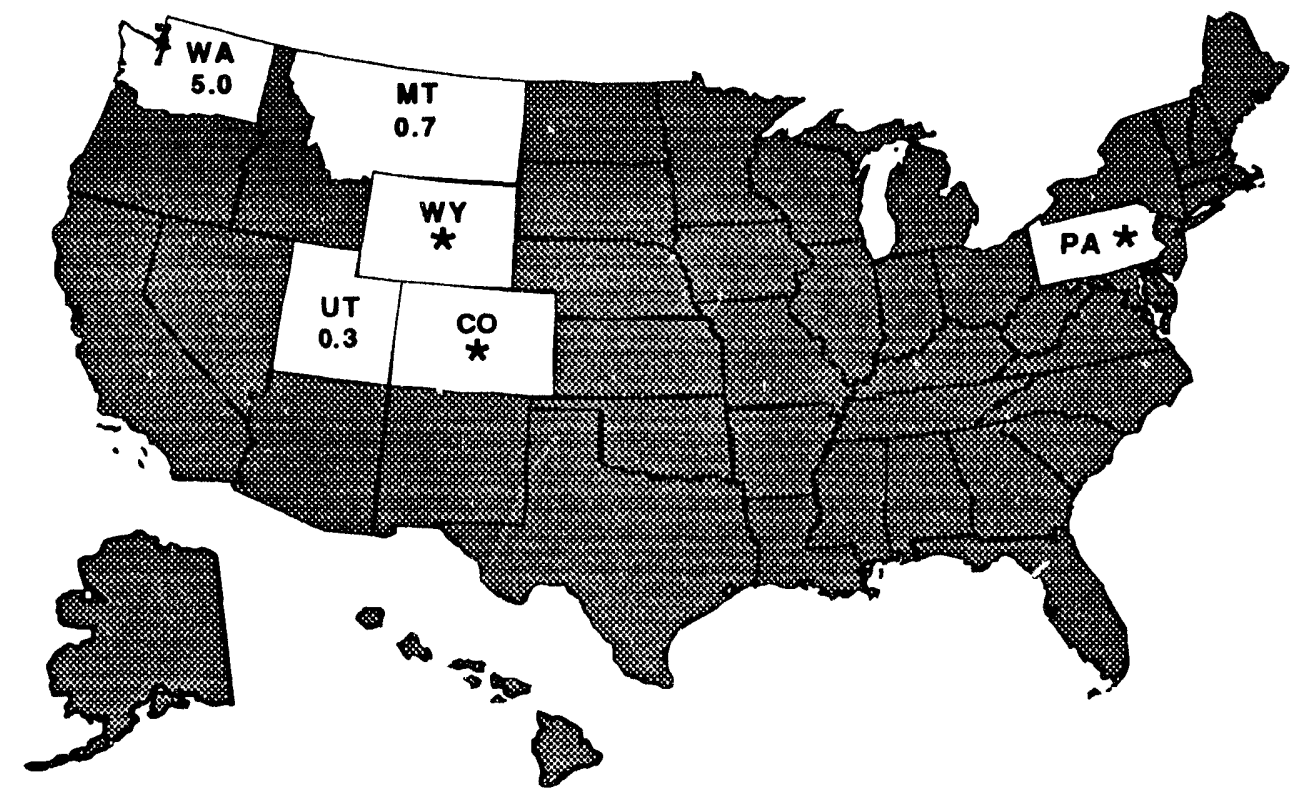

* Quantity is less than 0.1 million short tons.

Total

6.0

Note: Total may not equal sum of components because of independent rounding.

Source: Energy Information Administration, Form EIA-6, "Coal Distribution Report." 


\section{State Coal Profile: West Virginia}

West Virginia's bituminous coal resources are an important energy source for the Nation. More than 10 billion short tons have been produced since mining began in the early 1800 's. In 1992, West Virginia was the second-leading coal producer after Wyoming. West Virginia's coal output dominated tl.e States' mineral economy, accounting for about 86 percent of the estimated total value of all mineral commodities produced in the State.

Bituminous coal underlies more than two-thirds of West Virginia. The coal deposits are divided by a geological "hinge line" into the Northern and Southern fields. Coalbeds in the Northern Field generally occur in a regular sequence over a wide area, whereas those in the Southern Field vary more in thickness, and generally have a higher heating value and a lower sulfur content. The average thickness of the beds mined ranges from 3 to 7 feet.

About 20 coalbeds were mined in 1992 in the Northern Field, where the Pittsburgh and Upper Freeport were the leading sources of production. Foremost among the more than 40 coalbeds mined in the Southern Field were the Coalburg, Stockton-Lewis and Lower Kittanning. Most of West Virginia's coal can be converted into coke. The preeminent coking coal is the Pocahontas No. 3 , mined in the Southern Field.

The industrial use of coal in the State became significant in the early 1800's when it replaced wood as source of heat for the salt industry in Kanawha Valley. Around the mid-1800's, illuminating oil and lubricants were produced from cannel coal (a variety of bituminous coal) in Kanawha and Elk valleys. Coke production in the State began in the late 1800 's.

With railroad and river transportation facilities established in the late $1800^{\prime}$ s, the State's coal output rose rapidly from 23 million short tons in 1900 to 146 million short tons in 1927. This was followed by a drop during the Depression and then by a period of recovery. Production exceeded 150 million short tons during World War II and reached an all-time high of 176 million short tons in 1947, when large amounts of coal were shipped to Europe during the postwar recovery period. Subsequently, production fluctuated, reflecting the increased use of diesel locomotives and other competition from petroleum, lower demand for coking coal, changes in foreign demand for West Virginia coal, new requirements in mining and environmental laws, and coal miners' strikes. Production fell below 100 million short tons in the late 1970's before resuming an upward trend. About 162 million short tons were produced in 1992.

Underground mining has long been the dominant method of producing coal in West Virginia. Surface mining in the State became important in the 1940's. In 1992, the State's largest mine, with an output of over 4 million short tons, was the Federal No.2 underground mine of Eastern Associated Coal Corp., in Monongalia County. Because of relatively easy access to coalbeds on the sides of valleys, the State has many small mines, but their share of total production is relatively small. Mingo and Boone Counties were the leading coalproducing counties. Although West Virginia had the largest coal mining labor force in 1992, it ranked second to Kentucky in number of coal mines.

Most of the coal produced is shipped outside the State. Of the coal distributed in 1992, a little more than half was delivered to other States, nearly one-third was exported, and the rest remained in West Virginia. Of the coal shipped to other States, two-thirds was utility coal, delivered chiefly to Ohio and Pennsylvania. The balance was coking coal and coal for other industrial use. West Virginia was the Nation's leading source of coking coal for domestic markets and the major coal exporter. More than three-fourths of West Virginia's coal exports was estimated to be coking coal.

Coal consumption in West Virginia in 1992 totaled 32 million short tons, the bulk of it used to generate electricity. The electric utility industry has been the State's principal coal consumer since the late 1960's, with the increased use of utility coal offsetting losses in other sectors. Most of the utility coal is from West Virginia. The leading coal-burning generating facility is the 2,900-megawatt John E. Amos plant of Appalachian Power Company, in Putnam County. West Virginia mines supplied about half of the coking coal used in the State; the rest was mostly from Virginia. West Virginia coal also accounted for nearly all of the coal used by other industrial consumers, chiefly chemical and metal manufacturers. 


\section{West Virginia}
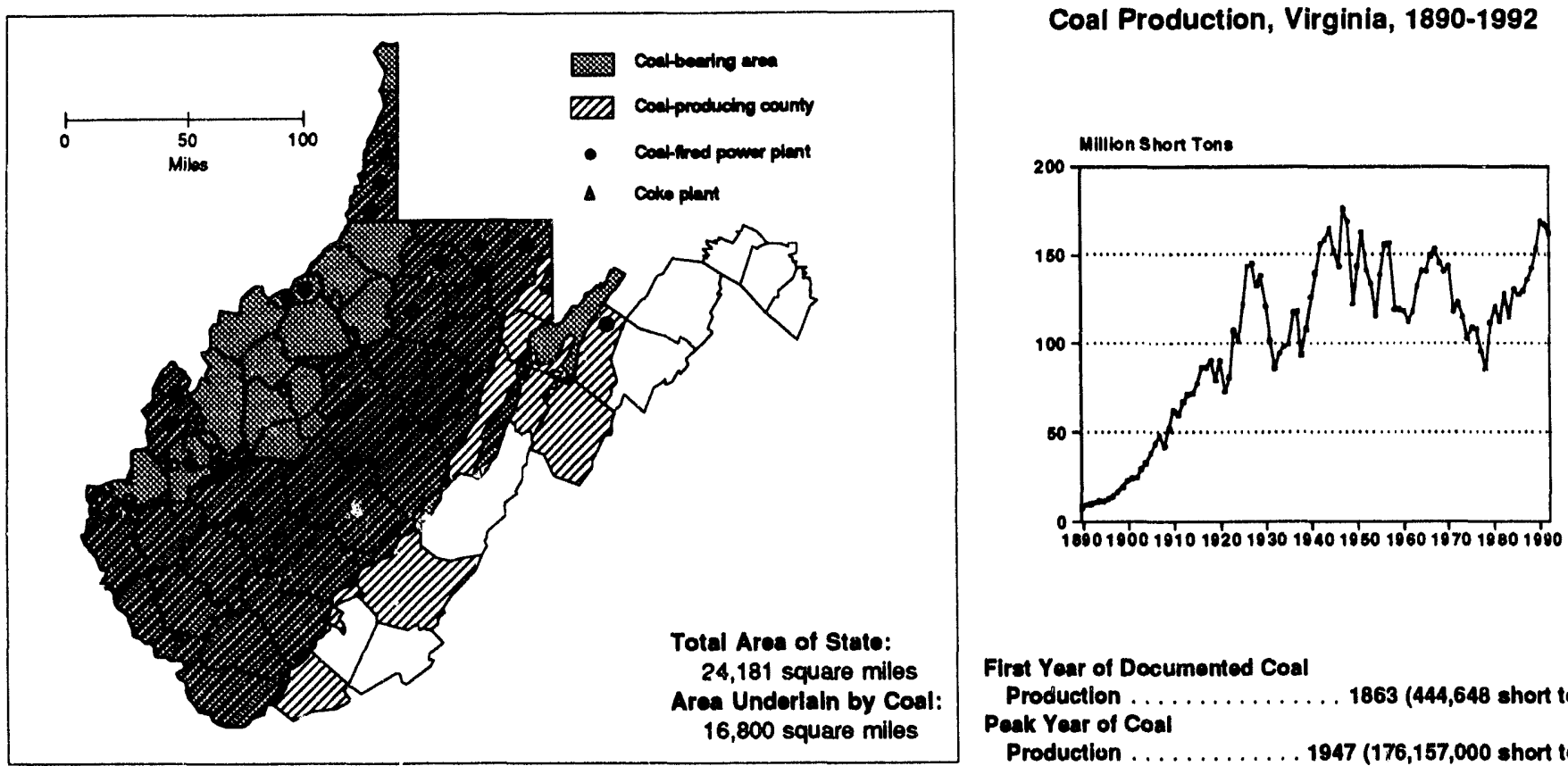

\section{Coal Reserves (Million Shcrt Tons)}

\begin{tabular}{|c|c|c|c|}
\hline Type of Reserve & Underg;ound & Surface & Total \\
\hline $\begin{array}{l}\text { Demonstrated Reserve Base: } \\
\text { (January 1, 1992) } \ldots \ldots \ldots \ldots \ldots \ldots \ldots \ldots \\
\text { Estimated Recoverable Reserves: } \\
\text { (January 1, 1992) } \\
\quad \text { Sulfur Content (pounds per million Btu) }\end{array}$ & 32,049 & 4,738 & 36,787 \\
\hline $\begin{array}{l}<0.61 \text { (low sulfur) } \ldots \ldots \ldots \ldots \ldots \ldots \ldots \ldots \ldots \\
0.61-1.67 \text { (medium sulfur) } \ldots \ldots \ldots \ldots \ldots \ldots \ldots \ldots \ldots\end{array}$ & $\begin{array}{l}5,708 \\
5,880 \\
5,517\end{array}$ & $\begin{array}{r}1,647 \\
1,052 \\
293\end{array}$ & $\begin{array}{l}7,355 \\
6,931 \\
5,810\end{array}$ \\
\hline
\end{tabular}

\section{Production}

\begin{tabular}{|c|c|c|c|c|c|}
\hline Sallent Data by Mino Typo & 1980 & 1985 & 1990 & 1991 & 1992 \\
\hline \multicolumn{6}{|l|}{ Underground } \\
\hline Quantity (thousand short tons) & 96,409 & 103,753 & 123,306 & 119,821 & 115,212 \\
\hline 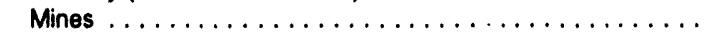 & 539 & 502 & 491 & 434 & 403 \\
\hline 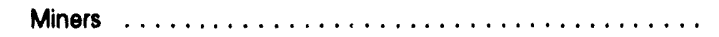 & 45,904 & 31,106 & 23,584 & 22,512 & 20,738 \\
\hline Productivity (short tons per miner per hour) $\ldots \ldots \ldots \ldots \ldots$ & 1.13 & 1.85 & 2.70 & 2.83 & 2.99 \\
\hline Average Mine Price (dollars per short ton) $\ldots \ldots \ldots \ldots \ldots$ & 36.46 & 34.31 & 29.75 & 29.63 & 29.14 \\
\hline \multicolumn{6}{|l|}{ Surtace } \\
\hline Quantity (thousand short tons) .. & 25,175 & 24,011 & 45,898 & 47,530 & 46,952 \\
\hline 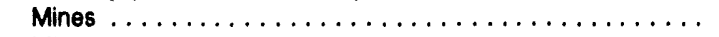 & 223 & 295 & 280 & 231 & 201 \\
\hline 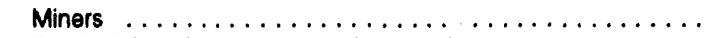 & 7,499 & 5,552 & 5,994 & 5,798 & 5,279 \\
\hline Productivity (shon tons per miner per hour) $\ldots \ldots \ldots \ldots$ & 1.67 & 2.54 & 4.02 & 4.18 & 4.27 \\
\hline Average Mine Price (dollars per short ton) $\ldots \ldots \ldots \ldots \ldots$ & 28.72 & 29.78 & 25.55 & 26.08 & 25.72 \\
\hline \multicolumn{6}{|l|}{ Total } \\
\hline Quantity (thousand short tons) & 121,584 & 127,764 & 169,205 & 167,352 & 162,164 \\
\hline Mines $\ldots \ldots \ldots \ldots \ldots \ldots$ & 762 & 797 & 771 & 665 & 604 \\
\hline 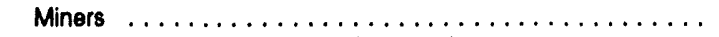 & 53,403 & 36,658 & 29,578 & 28,310 & 26,017 \\
\hline Productivity (short tons per miner per hour) . . . . . . . . & 1.21 & 1.95 & 2.96 & 3.11 & 3.27 \\
\hline Average Mine Price (dollars per short ton) $\ldots \ldots \ldots \ldots \ldots$ & 34.88 & 33.47 & 28.62 & 28.62 & 28.15 \\
\hline
\end{tabular}




\section{West Virginia}

Number of Mines by Production Range and Percent of Production, 1992

\begin{tabular}{|c|c|c|c|c|c|c|c|c|}
\hline \multirow{3}{*}{ Mine Type } & \multicolumn{8}{|c|}{ Production Range (thousand short tons) } \\
\hline & \multicolumn{2}{|c|}{1,000 and over } & \multicolumn{2}{|c|}{500 to 999} & \multicolumn{2}{|c|}{100 to 499} & \multicolumn{2}{|c|}{$<100$} \\
\hline & Number & Percent & Number & Percent & Number & Percent & Number & Percent \\
\hline Underground $\ldots \ldots \ldots \ldots \ldots \ldots \ldots \ldots \ldots$ & 28 & 48 & 23 & 13 & 152 & 31 & 200 & 8 \\
\hline Surface $\ldots \ldots \ldots \ldots \ldots \ldots \ldots \ldots \ldots$ & 13 & 50 & 13 & 22 & 38 & 21 & 137 & 7 \\
\hline All Mines $\ldots \ldots \ldots \ldots \ldots \ldots \ldots \ldots \ldots$ & 41 & 49 & 36 & 16 & 190 & 28 & 337 & 7 \\
\hline
\end{tabular}

\section{Coal Demand}

\begin{tabular}{|c|c|c|c|c|c|}
\hline Disposition & 1980 & 1985 & 1990 & 1991 & 1892 \\
\hline \multicolumn{6}{|l|}{ Consumption (thousand short tons) } \\
\hline Electric Utilities $\ldots \ldots \ldots \ldots \ldots \ldots \ldots$ & 28,499 & 31,367 & 29,873 & 27,557 & 28,050 \\
\hline Coke Piants $\ldots \ldots \ldots \ldots \ldots \ldots \ldots \ldots$ & $w$ & $\mathbf{w}$ & $w$ & $w$ & $\mathbf{W}$ \\
\hline Other Industrial $\ldots \ldots \ldots \ldots \ldots \ldots \ldots$ & 2,223 & 2,086 & 2,918 & 2,310 & 2,266 \\
\hline Residential and Commercial $\ldots \ldots \ldots \ldots$ & W & w & $w$ & $w$ & $w$ \\
\hline Total $\ldots \ldots \ldots \ldots \ldots \ldots \ldots \ldots \ldots$ & 34,673 & 34,907 & 34,896 & 31,843 & 32,019 \\
\hline \multicolumn{6}{|l|}{ Year-End Utillty Stocks } \\
\hline (thousand short tons) $\ldots \ldots \ldots \ldots \ldots \ldots$ & 7,903 & 5,453 & 6,874 & 7,707 & 7,863 \\
\hline \multicolumn{6}{|l|}{ Electricity Generation } \\
\hline Total (million kilowatthours) $\ldots \ldots \ldots \ldots \ldots$ & 70,798 & 79,536 & 77,364 & 71,254 & 72,334 \\
\hline Coal (percent) $\ldots \ldots \ldots \ldots \ldots \ldots \ldots$ & 99 & 99 & 99 & 99 & 99 \\
\hline Nuclear (percent) . . . . . . . . . . . . . . & 0 & 0 & 0 & 0 & 0 \\
\hline Other (percent) $\ldots \ldots \ldots \ldots \ldots \ldots \ldots$ & 1 & 1 & 1 & 1 & 1 \\
\hline
\end{tabular}

\section{Utilty Coal Data, 1992}

\begin{tabular}{|c|c|c|}
\hline Average Quality and Average Dellvered Cost & Produced In State & Rocelpts, All Sources \\
\hline Heat Content (million Btu per short ton) & 25.04 & 25.05 \\
\hline Sulfur Content (percent by weight) $\ldots \ldots \ldots \ldots \ldots \ldots \ldots \ldots \ldots$ & 1.60 & 2.05 \\
\hline Ash Content (percent by weight) $\ldots \ldots \ldots \ldots \ldots \ldots \ldots$ & 10.57 & 11.32 \\
\hline Pounds of Sultur per million Btu $\ldots \ldots \ldots \ldots \ldots \ldots \ldots$ & 1.28 & 1.64 \\
\hline Dollars per million Btu $\ldots \ldots \ldots \ldots \ldots \ldots \ldots \ldots \ldots$ & 1.57 & 1.47 \\
\hline Dollars per short ton $\ldots \ldots \ldots \ldots \ldots \ldots \ldots \ldots \ldots \ldots$ & 39.33 & 36.88 \\
\hline
\end{tabular}

Eetimated Total State Energy Conaumption, 1991: 783 trillion Btu (coal, 800; natural gas, 119; potroleum, 293; nuclear olectric power, 0; hydrodectric power, 11; other, 0; not Interetate flow of blectrichy and associated losses, -439 ).

$W=$ Withheid to avoid disclosure of individual company data.

Notes: Totals may not equal sum of components because of independent rounding. Data coverage-production: all mines. Number of mince: 1880 , mines that produced 10,000 short tons or more; other years, all mines. Number of miners and productivity: mines that produced 10,000 or more short tons and preparation plants that had 5,000 or more employee hours. Average mine price: minas that produced 10,000 or more shon tons. Average quality and average dellvered cout of utility coal: power plants with a generator nameplate capacity of 50 megawatts or more. Extent of coal-bearing areas and locations of coalconsuming plants shown on map are approximate; small coal deposits are not shown. Coal-producing counties shown on map exclude any county where all 1992 output was from mines producing less than 10,000 short tons.

Sources: Energy Information Administration-U.S. Coal Reserves: An Update by Heat and Sultur Content, February 1993; Coal Production 1992 and prior issues; Coal Data: A Reference; Quarterly Coal Repon October-December 1992 and prior issues; Electric Power Annual 1991 and prior issues; Electric Power Monthly, March 1993; Cost and Quality of Fuels for Electric Power Plants 1992; Inventory of Power Plants in the United States 1992; State Energy Data Report 1991: Consumption Estimates; Map of coal-bearing areas is based mainly on U.S. Geological Survey map, Coalfields of the United States, 1960. Data for historical graph 1890-1975, U.S. Department of the Interior, Geological Survey and Bureau of Mines (Minerals Yearbook and annual predecessor Mineral Resources of the United States); 1976 forward, Energy Information Administration. Coal Production 1992 and prior issues. 


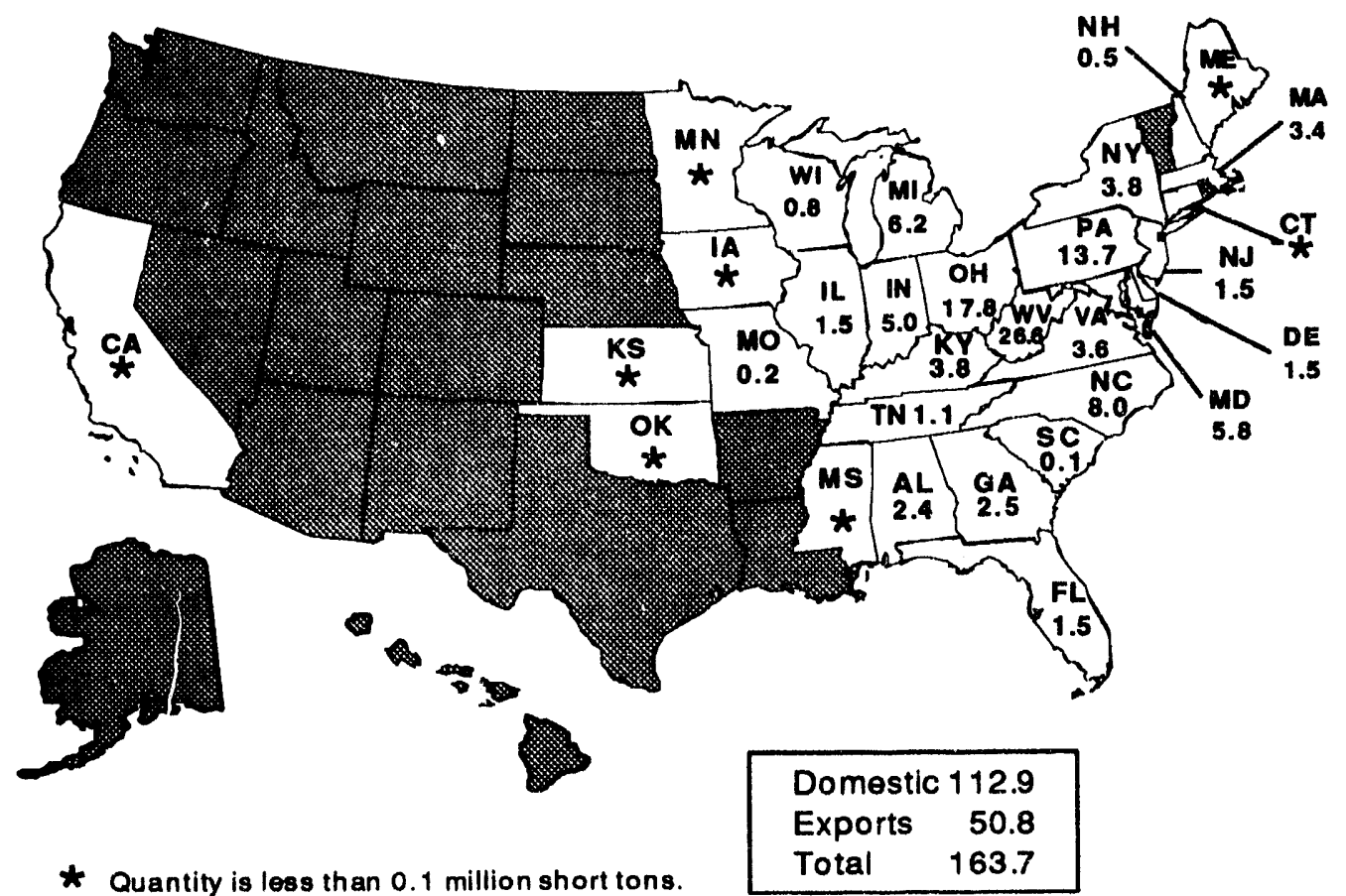

Transportation modes, domestic markets (percent): rail, 53; water, 36; truck, 5; tramway/conveyor, 5; unknown, 2.

Note: Total may not equal sum of components because of independent rounding.

Source: Energy Information Administration, Form EIA-6, "Coal Distribution Report."

\section{Origin of Coal Recelved In West Virginia, 1992}

(Million Short Tons)

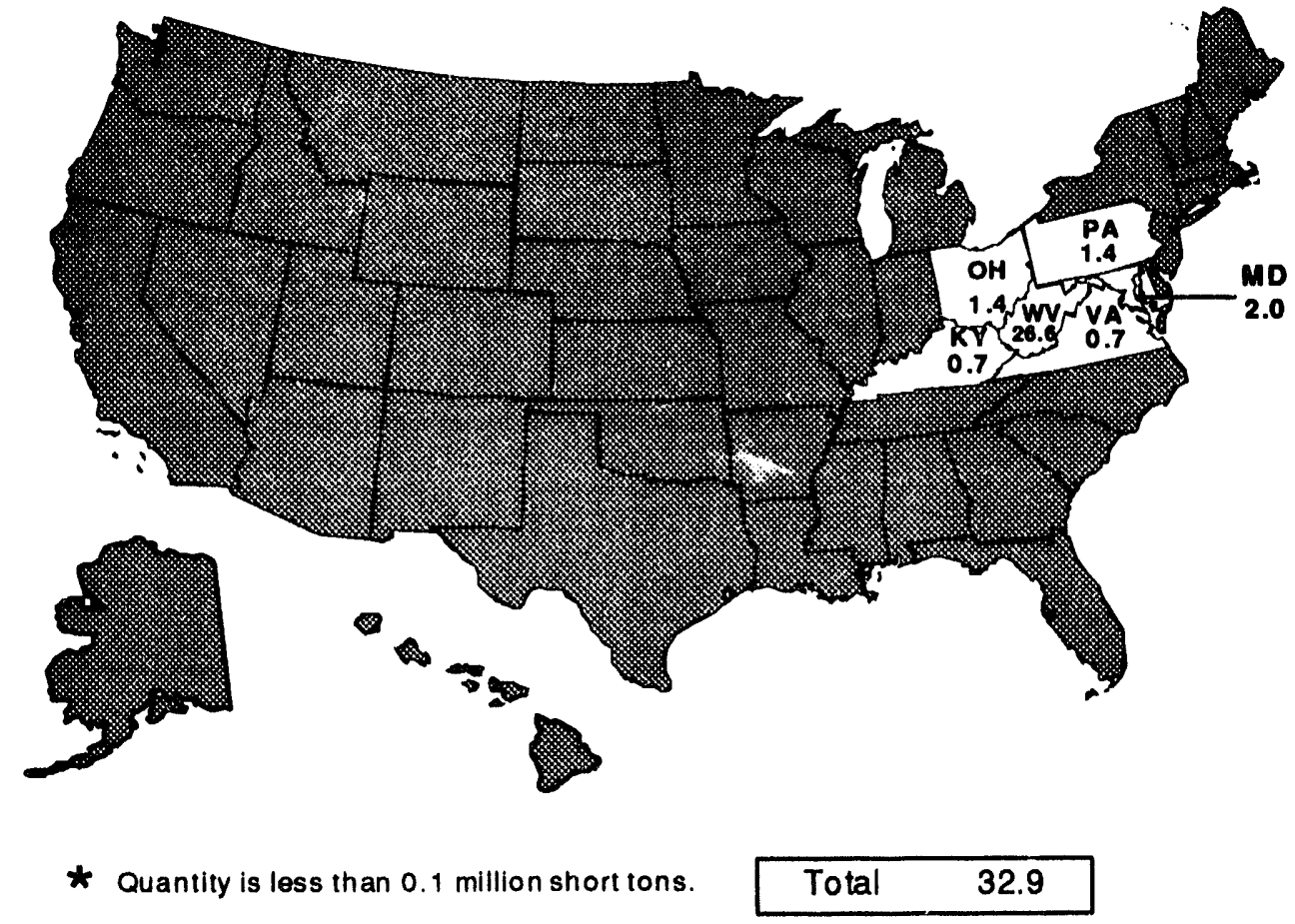

Note: Total may not equal sum of components because of independent rounding.

Source: Energy Information Administration, Form EIA-6, "Coal Distribution Report." 


\section{State Coal Profile: Wyoming}

Wyoming has been the Nation's leading coal producer since 1988 and the fastest growing coal-producing State over the past two decades. The dramatic rise in the State's coal output reflects the steadily increasing demand for its low-sulfur coal. Vast amounts of this coal underlie sparsely populated areas in thick, flatlying beds that can be mined by large-scale surface methods.

Coal is Wyoming's second most valuable commodity after crude oil. The value of coal output in 1992 was estimated to account for more than one-fourth of the value of all mineral production in the State. Federal coal leases generated $\$ 145$ million in royalties that were disbursed to the State and the Federal Government.

Coal occurs in Wyoming in 10 major coal-kearing regions that underlie about half of the State. Most of these are geologic depressions with relatively flat-lying beds. Although coal rank ranges from lignite to bituminous, subbituminous coal predominates. The Powder River Basin is the center of the State's coal industry. Production is chiefly from the Wyodak coalbed, which accounts for more than 80 percent of the State's total. The Wyodak, the thickest U.S. coalbed, averages about 70 feet in thickness and exceeds 100 feet in places. It has been the Nation's leading source of coal for about a decade. Virtually all of the coal produced is used to generate electricity. Some highquality Wyoming bituminous coal from other areas can be converted into metallurgical coke; a very small amount was produced in 1992.

Commercial mining began in Wyoming in 1867 along the Union Pacific Railroad's route in the southern part of the State. Extensive coal deposits provided fuel for locomotives on the transcontinental railroad, completed in 1869. Conversely, coal-hauling was a major source of revenue for the railroad. Other early industrial coal consumers in Wyoming included coke plants and a coal-gas plant. Coal was also shipped to other States.

Wyoming's annual coal output rose to more than 9 million short tons during World War I, but then declined due to competition from oil discovered in the State and the economic depression. World War II spurred production to nearly 10 million short tons in 1945. Ccui output then trended downward, falling helow 2 million short tons in 1958, the lowest point since 1889 . Many mines along the railroad closed as diesel-electric locomotives replaced coal-fired steam locomotives.

Wyoming's coal industry remained depressed until the early 1970's, when electric utilities turned to the State's low-sulfur coal to meet new air-quality standards. Further interest in Wyoming coal was stimulated when the Arab oil embargo of 1973 brought sharp rises in oil prices and made coal the most economical fuel for power plants. The State's thick beds of low-sulfur coal provided a base for a vigorous new coal industry. As large surface mines were opened, the railroads upgraded existing lines and laid new track to support the heavy traffic of unit coal trains. The resulting coalmining boom drove production to record-breaking levels. From 95 million short tons in 1980, coal production doubled to more than 190 million short tons in 1991 and 1992.

Although underground mines produced most of Wyoming's coal before World War II, surface mines now predominate. Wyoming is notable for its many large surface mines in Campbell County in the Powder River Basin. In 1992, the State claimed 7 of the 10 largest U.S. coal mines. Ranking first was the exceptionally large Black Thunder mine of Thunder Basin Coal Company (a subsidiary of ARCO Coal Company), which produced about 29 million short tons. Also in Wyoming is the largest and deepest U.S. open-pit coal mine (1 mile long and over 900 feet deep), the Kemmerer mine of Pittsburg \& Midway Coal Mining Company in Lincoln County. More than 90 percent of Wyoming coal production in 1992 was from Federal leases.

Most of Wyoming's coal is shipped to utilities out of State, and a small amount is exported. Virtually all of the 27 million short tons of coal consumed in Wyoming in 1992 was utility coal produced in the State. Wyoming's largest coal-burning utility is the 2,080-megawatt Jim Bridger plant of PacifiCorp, in Sweetwater County. A small amount of coal was consumed in manufacturing such products as sodium carbonate (soda ash) from trona, bentonite, cement, and in processing sugar beets. Some coal was also converted into chemical (synthetic) coke and used for processing phosphate rock in Idaho. 


\section{Wyoming}

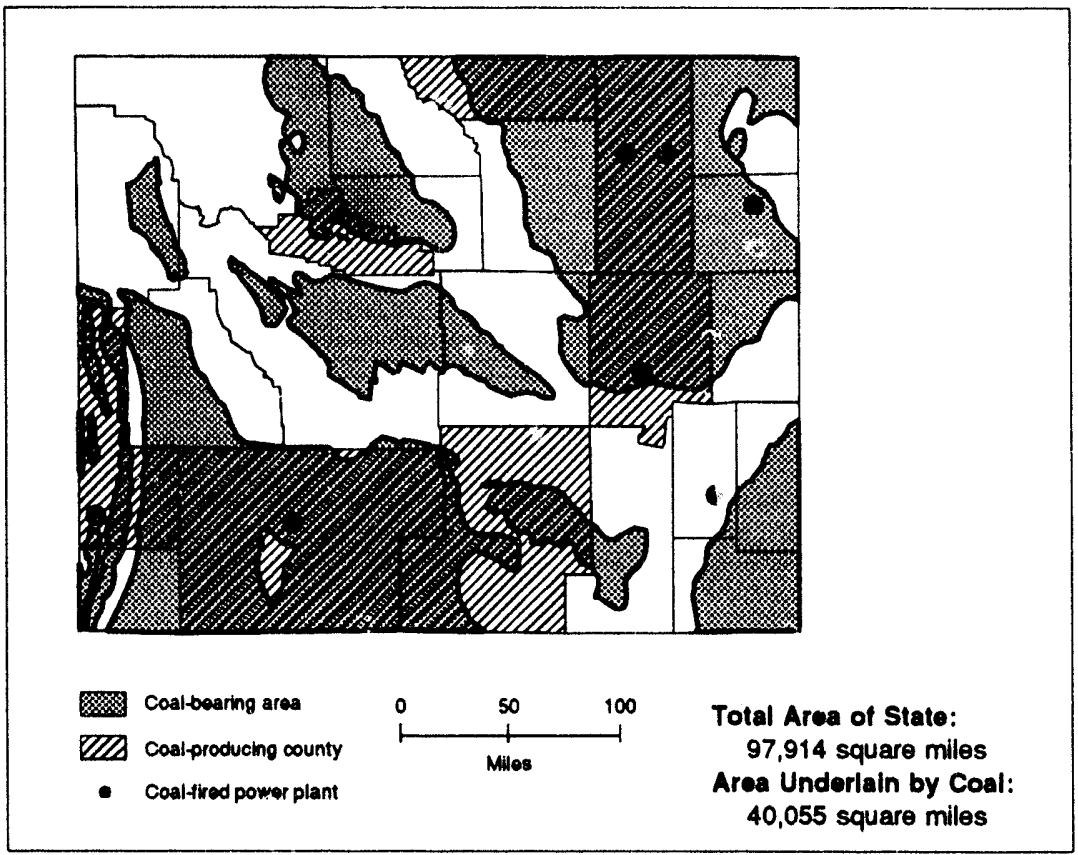

Coal Production, 1890-1992

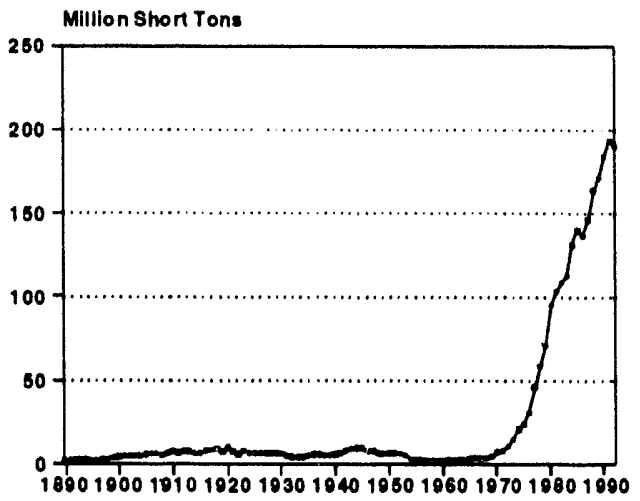

First Year of Documented Coal

Production . . . . . . . . . . . . . 1865 (800 short tons) Paak Year of Coal

Production . 1991 (193,854,000 short tons)

\section{Coal Reserves (Million Short Tons)}

\begin{tabular}{|c|c|c|c|}
\hline Type of Reserve & Underground & Surface & Total \\
\hline \multicolumn{4}{|l|}{ Deinonstrated Reserve Base: } \\
\hline \multirow{2}{*}{\multicolumn{4}{|c|}{$\begin{array}{l}\text { Estimated Recoverable Recerves: } \\
\text { (January 1, 1992) } \\
\text { Sulfur Content (pounds per million Btu) }\end{array}$}} \\
\hline & & & \\
\hline$<0.61$ (low sulfur) $\ldots \ldots \ldots \ldots \ldots \ldots \ldots$ & 11,119 & 13,714 & 24,833 \\
\hline $0.61-1.67$ (medium suifur) $\ldots \ldots \ldots \ldots \ldots \ldots \ldots$ & 11,179 & 6,635 & 17,814 \\
\hline$>1.67$ (high sulfur) $\ldots \ldots \ldots \ldots \ldots \ldots$ & 674 & 2,776 & 3,449 \\
\hline $\begin{array}{l}\text { Total } \ldots \ldots \ldots \ldots \ldots \ldots \ldots \ldots \ldots \ldots \ldots \ldots \ldots \ldots \ldots \ldots \ldots \ldots \\
\text { Estimated Recoverable Resorves }\end{array}$ & 22,972 & 23,125 & 46,096 \\
\hline at Actlve Mines, Year-End $1992 \ldots \ldots \ldots \ldots \ldots$ & $\mathbf{W}$ & W & 6,751 \\
\hline
\end{tabular}

\section{Production}

\begin{tabular}{|c|c|c|c|c|c|}
\hline Salient Data by Mine Type & 1080 & 1985 & 1990 & 1981 & 1992 \\
\hline \multicolumn{6}{|l|}{ Underground } \\
\hline Quantity thousand short tons) $\ldots \ldots \ldots \ldots \ldots \ldots$ & 1,633 & 1,058 & 1,722 & 2,418 & 2,511 \\
\hline 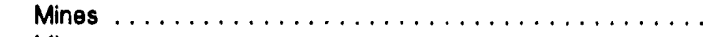 & 3 & 1 & 4 & 4 & 4 \\
\hline 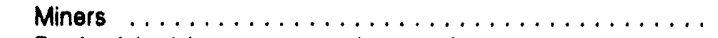 & 465 & 270 & 255 & 258 & 268 \\
\hline Productivity (short tons per miner per hour) $\ldots \ldots \ldots \ldots \ldots$ & 1.02 & 1.90 & 2.80 & 4.17 & 4.19 \\
\hline Average Mine Price (dollars per short ton) $\ldots \ldots \ldots \ldots \ldots$ & W & $W$ & W & $W$ & $W$ \\
\hline \multicolumn{6}{|l|}{ Surface } \\
\hline Quantity (thousand short tons) & 93,254 & 139,656 & 182,527 & 191,437 & 187,661 \\
\hline 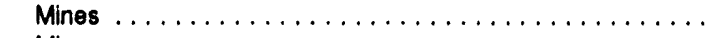 & 22 & 29 & 29 & 27 & 26 \\
\hline 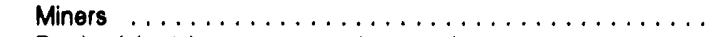 & 4,334 & 4,174 & 3.075 & 3,043 & 3,058 \\
\hline Productivity (short tons per miner per hour) $\ldots \ldots \ldots \ldots \ldots$ & 9.75 & 15.09 & 22.84 & 23.11 & 22.76 \\
\hline Average Mine Price (dollars per short ton) . . . . . . . . . . . & W & W & W & W & W \\
\hline \multicolumn{6}{|l|}{ Total } \\
\hline Quantity (thousand short tons) & 94,887 & 140,714 & 184,249 & 193,854 & 190,172 \\
\hline 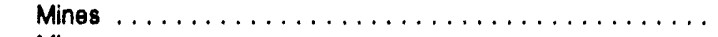 & 25 & 30 & 33 & 31 & 30 \\
\hline 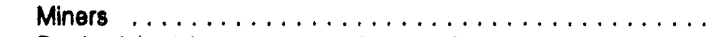 & 4,779 & 4,444 & 3,330 & 3,301 & 3,326 \\
\hline Productivity short tons per miner per $h r \quad 1 \ldots \ldots \ldots$ & 8.99 & 14.34 & 21.41 & 21.87 & 21.50 \\
\hline Average Mine Price (dollars per short i..., . . . . . . . . . . & 10.54 & 11.36 & 8.43 & 8.09 & 8.14 \\
\hline
\end{tabular}




\section{Wyoming}

Number of Mines by Production Range and Percent of Production, 1992

\begin{tabular}{|c|c|c|c|c|c|c|c|c|}
\hline \multirow{3}{*}{ Mine Type } & \multicolumn{8}{|c|}{ Production Range (thousand short tons) } \\
\hline & \multicolumn{2}{|c|}{1,000 and over } & \multicolumn{2}{|c|}{500 to 999} & \multicolumn{2}{|c|}{100 to 499} & \multicolumn{2}{|c|}{$<100$} \\
\hline & Number & Percent & Number & Percent & Number & Percent & Number & Percent \\
\hline Underground & $<1$ & 75 & 0 & 0 & 2 & 25 & 1 & $<1$ \\
\hline Surface & 19 & 99 & 1 & $<1$ & 1 & $<1$ & 5 & $<1$ \\
\hline All Mines ... & 20 & 99 & 1 & $<1$ & 3 & $<1$ & 6 & $<1$ \\
\hline
\end{tabular}

\section{Coal Demand}

\begin{tabular}{|c|c|c|c|c|c|}
\hline Disposition & 1980 & 1985 & 1990 & 1891 & 1992 \\
\hline \multicolumn{6}{|l|}{ Consumption (thousand short tons) } \\
\hline Electric Utilitios $\ldots \ldots \ldots \ldots \ldots \ldots \ldots$ & 13,499 & 21,173 & 23,526 & 23,115 & 25,114 \\
\hline Coke Plants . . . . . . . . . . . . . & 0 & 0 & 0 & 0 & 0 \\
\hline Other Industrial $\ldots \ldots \ldots \ldots \ldots \ldots \ldots$ & $w$ & $w$ & 1,857 & 1,896 & 1,861 \\
\hline Residential and Commercial . . . . . . . & $w$ & $w$ & 130 & 138 & 99 \\
\hline Total $\ldots \ldots \ldots \ldots \ldots \ldots \ldots$ & 15,209 & 23,155 & 25,514 & 25,150 & 27,074 \\
\hline \multicolumn{6}{|l|}{ Year-End Utility Stocke } \\
\hline (thousand short tons) $\ldots \ldots \ldots \ldots$ & 1,813 & 4,022 & 3,215 & 2,767 & 2,153 \\
\hline \multicolumn{6}{|l|}{ Electrictty Ceneration } \\
\hline Total (million kilowatthours) & 22,351 & 35,861 & 39,378 & 38,667 & 41,852 \\
\hline Coal (percent) $\ldots \ldots \ldots \ldots \ldots \ldots$ & 95 & 97 & 98 & 98 & 98 \\
\hline Nuclear (percent) $\ldots \ldots \ldots \ldots \ldots \ldots$ & 0 & 0 & 0 & 0 & 0 \\
\hline Other (percent) $\ldots \ldots \ldots \ldots \ldots \ldots$ & 5 & 3 & 2 & 2 & 2 \\
\hline \multicolumn{2}{|c|}{ Average Quality and Average Dellvered Cost } & \multicolumn{2}{|c|}{ Produced in State } & \multicolumn{2}{|c|}{ Recolpte, All Sources } \\
\hline \multicolumn{2}{|l|}{ Heat Content (million Btu per short ton) } & \multicolumn{2}{|c|}{17.36} & \multicolumn{2}{|c|}{17.68} \\
\hline \multicolumn{2}{|c|}{ Sulfur Content (percent by weight) $\ldots \ldots \ldots \ldots \ldots \ldots \ldots \ldots$} & \multicolumn{2}{|c|}{.38} & \multicolumn{2}{|c|}{.52} \\
\hline \multicolumn{2}{|c|}{ Ash Content (percent by wolght) $\ldots \ldots \ldots \ldots \ldots \ldots \ldots \ldots$} & \multicolumn{2}{|c|}{5.48} & \multicolumn{2}{|c|}{7.54} \\
\hline \multicolumn{2}{|c|}{ Pounds of Sulfur per million Btu $\ldots \ldots \ldots \ldots \ldots \ldots \ldots \ldots$} & \multicolumn{2}{|c|}{.44} & \multicolumn{2}{|c|}{.59} \\
\hline \multicolumn{2}{|c|}{ Dollars per million Btu $\ldots \ldots \ldots \ldots \ldots \ldots \ldots \ldots \ldots$} & \multicolumn{2}{|c|}{1.27} & \multicolumn{2}{|c|}{.76} \\
\hline \multicolumn{2}{|c|}{ Dollars per short ton $\ldots \ldots \ldots \ldots \ldots \ldots \ldots \ldots \ldots$} & \multicolumn{2}{|c|}{22.10} & \multicolumn{2}{|c|}{13.42} \\
\hline
\end{tabular}

Estimated Total State Enorgy Consumption, 1991: 391 trillion Btu (coal, 450; natural gas, 103; petroleum, 116; nuclear electric power, 0; hydroelectric poimer, 8; other, 0; net intorstate flow of electrictly and asecoclated losese, -286).

$W=$ Withheld to avoid disclosure of individual company data.

Notes: Totals may not equal eum of components because of indopendent rounding. Data coverage-Production: all mines. Number of mince: 1980 , mines that produced 10,000 short tons or more; other years, all mines. Number of minere and productivity: mines that produced 10,000 or more short tons and preparation plants that had 5,000 or more employee hours. Average mine price: mines that produced 10,000 or more short tons. Average quality and average delivered coest of utility coal: power plants with a generator nameplate capacity of 50 megawatts or more. Extent of coal-bearing areas and locations of coal-consuming plants shown on map are approximate; small coal deposits are not shown. Coal-producing counties shown on map exclude any county where all 1992 output was from mines producing less than 10,000 short tons.

Sources: Energy Information Administration-U.S. Coal Reserves: An Update by Heat and Sulfur Content, February 1993; Coal Production 1992 and prior issues; Coal Data: A Referenx;; Quantenly Coal Repon October-December 1992 and prior issues; Electric Power Annual 1991 and prior issues; Electric Power Monthly, March 1993; Cost and Quality off is for Electric Power Plants 1992; Inventory of Power Plants in the United States 1992; State Energy Data Report 1991: Consumption Estmates; Map of coal-uearing areas is based mainly on U.S. Geological Survey map, Coalfields of the United States, 1960. Data for historical graph 1890-1975, U.S. Department of the Interior, Geological Survey and Bureau of Mines (Minerals Yearbook and annual predecessor Mineral Resources of the United States); 1976 forward, Energy Information Administration, Coal Production 1992 and prior issues. 


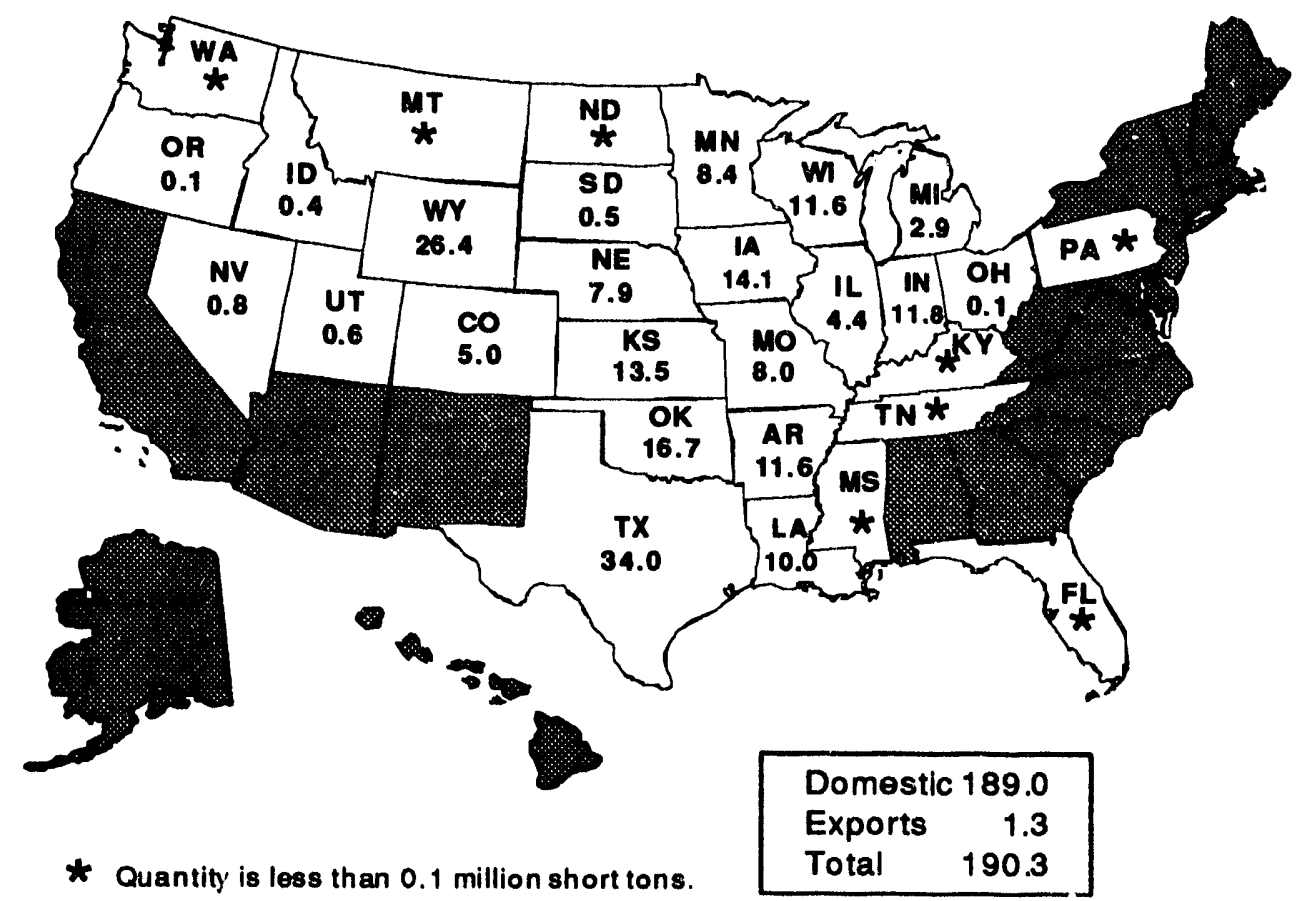

Transportation modes, domestic markets (percent): rail, 86; water, 7; truck, 2; tramway/conveyor, 5; unknown, $<1$.

Note: Total may not equal sum of components because of independent rounding.

Source: Enengy Information Administration, Form EIA-6, "Coal Distribution Report."

\section{Origin of Coal Recelved in Wyoming, 1992}

(Million Short Tons)

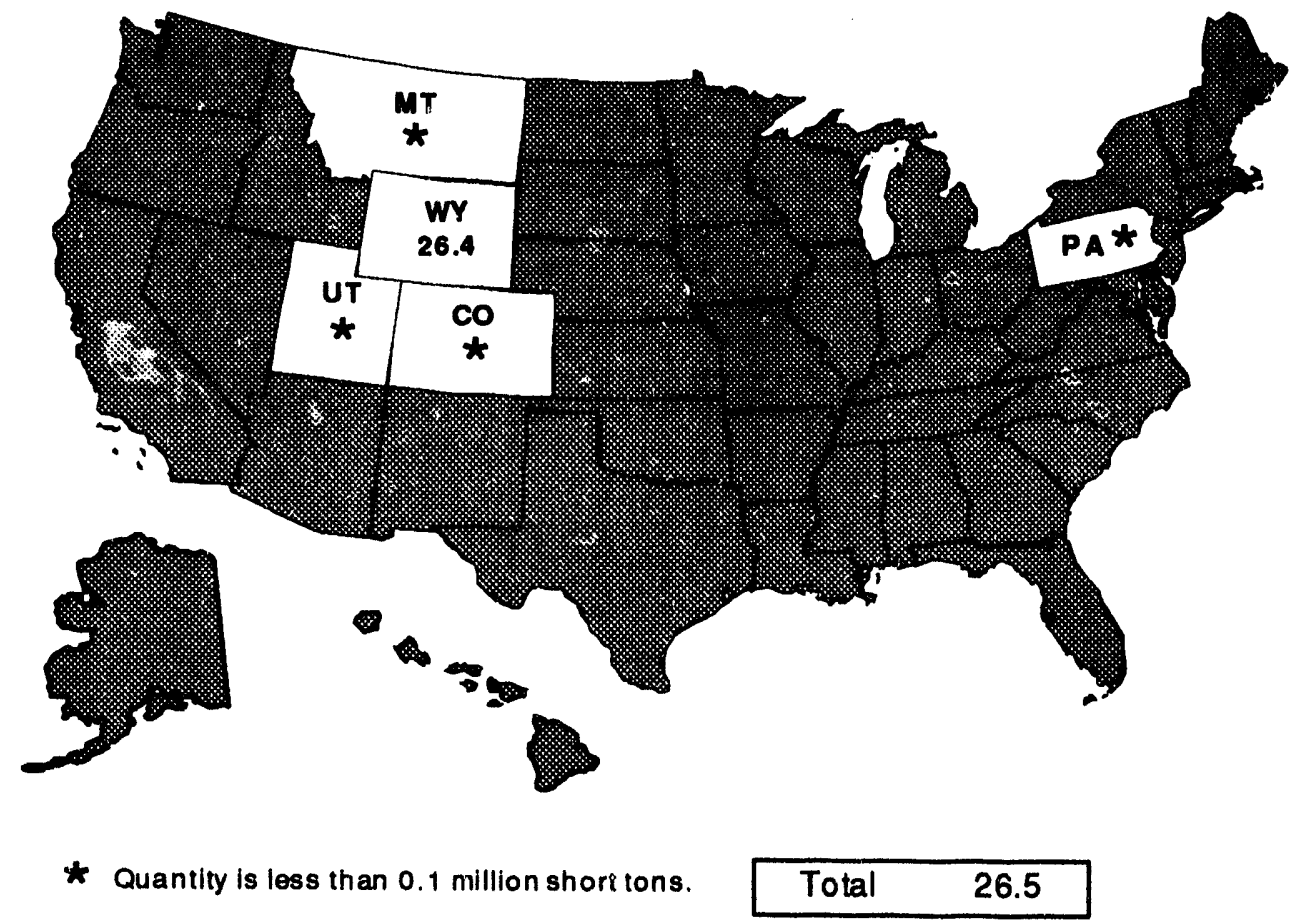

Note: Total may not equal sum of components because of independent rounding.

Source: Energy Information Administration, Form EIA-6, "Coal Distribution Report." 


\section{United States}

Total Area of United States: $3,615,122$ square miles Area Underlain by Coal: 458,600 square miles

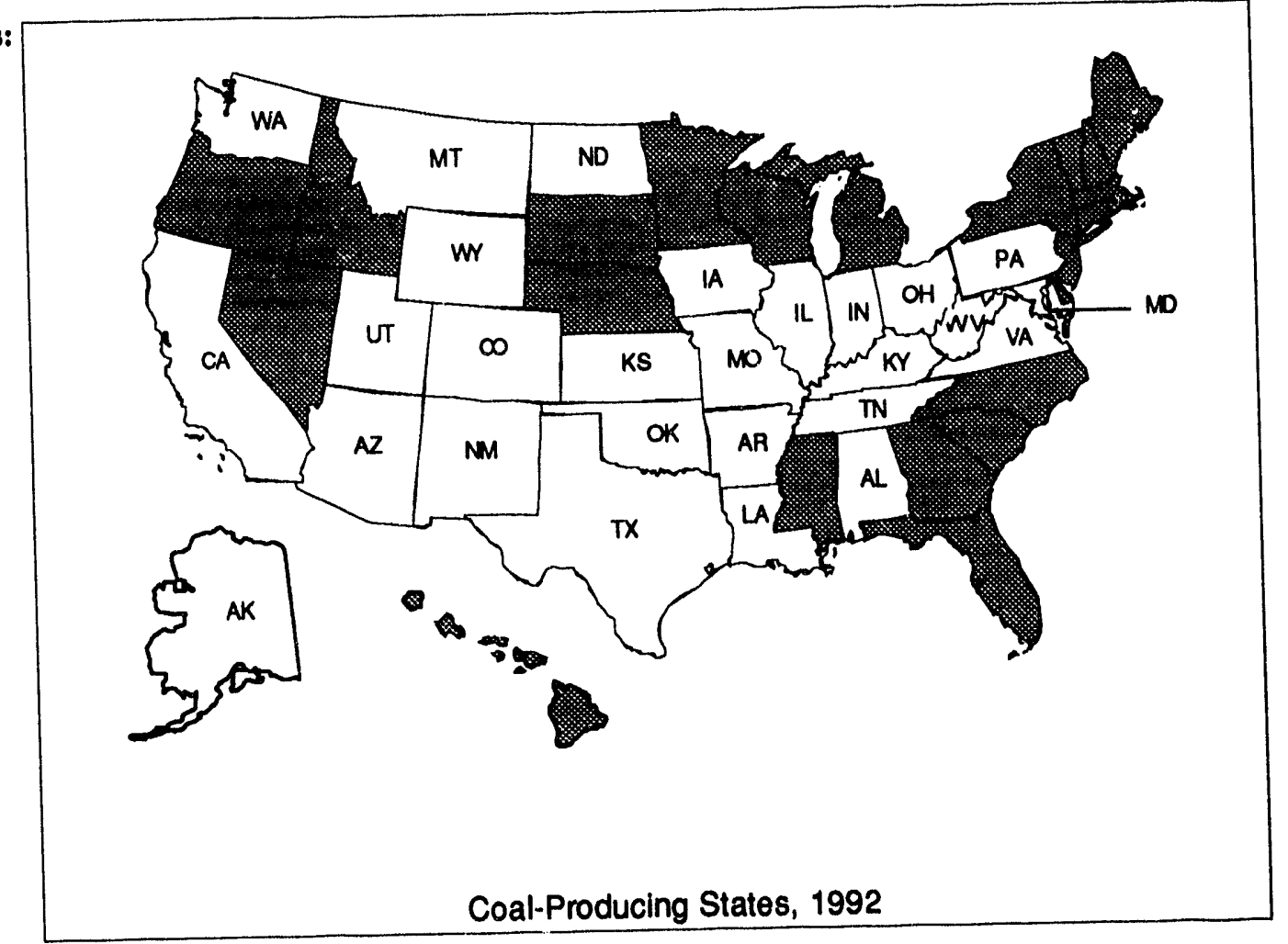

Coal Reserves (Million Short Tons)

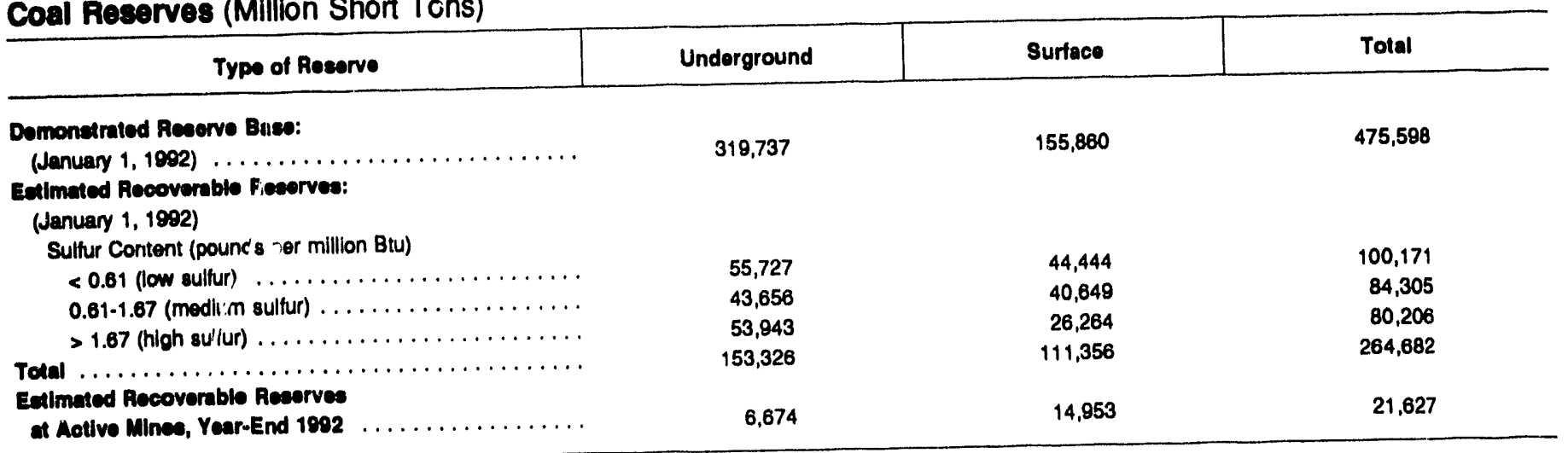




\section{United States}

\section{Production}

\begin{tabular}{|c|c|c|c|c|c|}
\hline Sallent Data by Mine Type & 1980 & 1985 & 1990 & 1991 & 1992 \\
\hline \multicolumn{6}{|l|}{ Underground } \\
\hline Quanity (thousand short tons) $\ldots \ldots \ldots \ldots \ldots \ldots \ldots$ & 337,508 & 350,800 & 424,546 & 407,225 & 407,239 \\
\hline Mines $\ldots \ldots \ldots \ldots \ldots \ldots \ldots \ldots \ldots \ldots \ldots \ldots \ldots$ & 1,887 & 2,208 & 1,690 & 1,489 & 1,354 \\
\hline 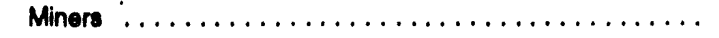 & 150,685 & 107,357 & 84,154 & 78,050 & 70,907 \\
\hline Productuity (short tons per miner per hour) $\ldots \ldots \ldots \ldots \ldots$ & 1.20 & 1.78 & 2.54 & 2.69 & 2.93 \\
\hline Average Mine Price (dollars per short tons) . . . . . . . . . . & 33.50 & 32.91 & 28.58 & 28.56 & 27.83 \\
\hline \multicolumn{6}{|l|}{ Suriseo } \\
\hline Quantity (thousand short tons) $\ldots \ldots \ldots \ldots \ldots \ldots$ & 492,192 & 532,838 & 604,529 & 588,759 & 590,306 \\
\hline Mines $\ldots \ldots \ldots \ldots \ldots \ldots \ldots \ldots \ldots \ldots \ldots \ldots$ & 2,082 & 2.556 & 1,740 & 1,533 & 1,392 \\
\hline Miners $\ldots \ldots \ldots \ldots \ldots \ldots \ldots \ldots \ldots \ldots \ldots$ & 77,884 & 61,924 & 47,152 & 42,552 & 39,289 \\
\hline Productivity (shon tons per miner per hour) $\ldots \ldots \ldots \ldots$ & 3.21 & 4.24 & 5.94 & 6.38 & 6.59 \\
\hline Average Mine Price (dollars per short tons) . . . . . . . . . & 18.78 & 20.13 & 16.98 & 16.60 & 16.34 \\
\hline \multicolumn{6}{|l|}{ Total } \\
\hline Quantity (thousand short tons) & 829,700 & 883,638 & $1,029,076$ & 995,984 & 997,545 \\
\hline Mines . . . . . . . . . . . . . . . . . . . . & 3,969 & 4,764 & 3,430 & 3,022 & 2,746 \\
\hline Miners $\ldots \ldots \ldots \ldots \ldots \ldots \ldots \ldots \ldots \ldots \ldots$ & 228,569 & 189,281 & 131,306 & 120,602 & 110,196 \\
\hline Productwity (short tons per miner per hour) $\ldots \ldots \ldots \ldots \ldots$ & 1.93 & 2.74 & 3.83 & 4.09 & 4.36 \\
\hline Average Mine Price (dollars per short ton) $\ldots \ldots \ldots \ldots \ldots$ & 24.65 & 25.20 & 21.76 & 21.49 & 21.03 \\
\hline
\end{tabular}

\section{Number of Mines by Production Range and Percent of Production, 1992}

\begin{tabular}{|c|c|c|c|c|c|c|c|c|}
\hline \multirow{3}{*}{ Mins Type } & \multicolumn{8}{|c|}{ Production Range (thousand short tons) } \\
\hline & \multicolumn{2}{|c|}{1,000 and over } & \multicolumn{2}{|c|}{500 to 999} & \multicolumn{2}{|c|}{100 to 499} & \multicolumn{2}{|c|}{$<100$} \\
\hline & Number & Percent & Number & Percent & Number & Percent & Number & Percent \\
\hline Underground $\ldots \ldots \ldots \ldots \ldots \ldots \ldots \ldots \ldots$ & 113 & 57 & 66 & 11 & 440 & 25 & 735 & 7 \\
\hline Surtece $\ldots \ldots \ldots \ldots \ldots \ldots \ldots \ldots \ldots$ & 99 & 75 & 74 & 9 & 308 & 12 & 913 & 4 \\
\hline All Mines $\ldots \ldots \ldots \ldots \ldots \ldots \ldots \ldots \ldots \ldots$ & 212 & 68 & 140 & 10 & 746 & 17 & 1,618 & 5 \\
\hline
\end{tabular}

Coal Production, United States, 1890-1992

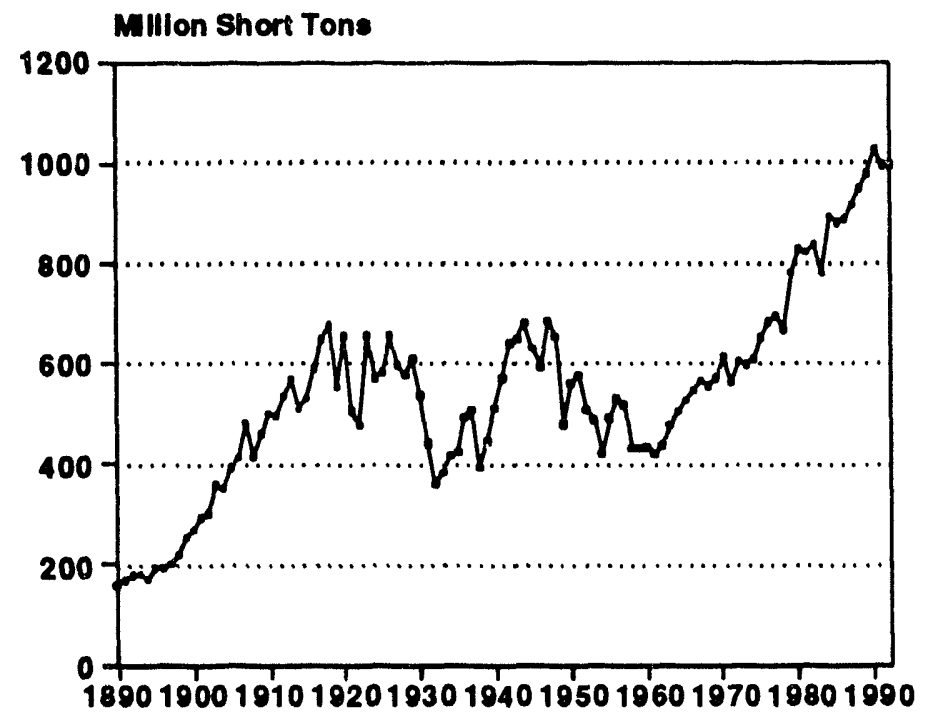

First Year of Documented Coal Production . . . . . . . 1748 (50 short tons)

Peak Year of Coal Production . . . . . . . . . . . . $1990(1,029,076,000$ short tons) 


\section{United States}

Transportation modes, domestic market 1992 (percent):

Rall 57, Water 17, Truck 12, Tramway, conveyor and slurny pipeline 13, Unknown $<1$.

Coal Demand

\begin{tabular}{|c|c|c|c|c|c|}
\hline Dispoeltion & 1980 & 1985 & 1000 & 1991 & 1992 \\
\hline \multicolumn{6}{|l|}{ Consumption (thousand short tons) } \\
\hline Electric Utllites . . . . . . . . . . . & 569,274 & 693,841 & 773,549 & 772,268 & 779,830 \\
\hline Coke Plants $\ldots \ldots \ldots \ldots \ldots \ldots \ldots$ & 68,657 & 41,058 & 38,877 & 33,854 & 32,366 \\
\hline Other Industrial $\ldots \ldots \ldots \ldots \ldots \ldots$ & 60,347 & 75,372 & 76,330 & 75,405 & 74,203 \\
\hline Residental and Commercial ......... & 6,452 & 7,779 & 6.724 & 6,094 & 6,153 \\
\hline Total $\ldots \ldots \ldots \ldots \ldots \ldots \ldots \ldots$ & 702,729 & 818,049 & 895,480 & 887,621 & 892,552 \\
\hline \multicolumn{6}{|l|}{ Year-End Utiliny Stocks } \\
\hline (thousand short tons) $\ldots \ldots \ldots \ldots \ldots$ & 183,010 & 156,376 & 156,166 & 157,876 & 153,846 \\
\hline \multicolumn{6}{|l|}{ Electriclly Coneration } \\
\hline Total (million kllowatthours) & $2,286,439$ & $2,469,841$ & $2,808,151$ & $2,825,023$ & $2,795,964$ \\
\hline Coal (percent) $\ldots \ldots \ldots \ldots$ & 51 & 57 & 56 & 55 & 56 \\
\hline Nuclear (percent) $\ldots \ldots \ldots \ldots \ldots$ & 11 & 16 & 21 & 22 & 22 \\
\hline 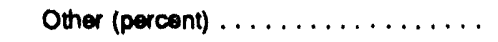 & 38 & 27 & 23 & 23 & 22 \\
\hline
\end{tabular}

Utility Coal Data, 1992

\begin{tabular}{|c|c|c|}
\hline Average Qually and Average Dellvered Coot & Produced in U.S. & Recolpis, All Sources \\
\hline Heat Content (million Btu per short ton) $\ldots \ldots \ldots \ldots \ldots \ldots$ & 20.78 & 20.79 \\
\hline Sulfur Content (percent by weight) $\ldots \ldots \ldots \ldots \ldots \ldots \ldots$ & 1.29 & 1.29 \\
\hline Ash Content (percent by weight) $\ldots \ldots \ldots \ldots \ldots \ldots$ & 9.72 & 9.71 \\
\hline Pounds of Sultur per million Btu $\ldots \ldots \ldots \ldots \ldots \ldots \ldots \ldots$ & 1.24 & 1.24 \\
\hline Dollars per million Bru $\ldots \ldots \ldots \ldots \ldots \ldots \ldots \ldots \ldots$ & 1.41 & 1.41 \\
\hline Dollars per short ton $\ldots \ldots \ldots \ldots \ldots \ldots \ldots \ldots \ldots \ldots$ & 29.34 & 29.36 \\
\hline
\end{tabular}

Eetimated Total U.S. Energy Conoumption, 1901: 81,119 trillion Btu (coal, 18,754; natural ges, 19,625; petroleum, 32,846; nuclear electric power, 6,579; hydrodectile power, 3,116; other, 199).

Notes: Tolals may not equal sum of components because of independent rounding. Data coverage-Productlon: all mines. Number of mines: 1980, mines that produced 10,000 short tons or more; other years, all mines. Number of miners and productivity: mines that produced 10,000 or more short tons and preperation plants that hed 5,000 or more employee hours. Average mins price: mines that produced 10,000 or more short tons. Average quality and avereos dellvered coet of utlity coal: power plants with a generator nameplate capacity of 50 megawatts or more. Extent of coal-bearing areas and locations of coal-consuming plants shown on map are approximate; small coal deposits are not shown. Coal-producing counties shown on map exclude any county where all 1092 output was from mines producing lese than 10,000 short tons.

Sources: Energy Intormation Administration-U.S. Coal Reserves: An Update by Heat and Sultur Content, February 1993; Coal Production 1992 and prior Issues; Coal Data: A Reterence; Quarterty Coal Report October-December 1992 and prior issues; Llectric Power Annual 1991 and prior issues; Electric Power Monthly, March 1993; Cost and Quality of Fuols for Electric Power Plants 1992; Inventory of Power Plants in the United States 1992; State Energy Data Report 1991: Consumption Estimates; Map of coal-bearing areas is based mainly on U.S. Geological Survey map, Coalfields of the United States, 1960. Data for historical graph 1890-1975, U.S. Department of the Interlor, Geological Survey and Bureau of Mines (Minerals Yearbook and annual preuecessor Mineral Resources of the United States); 1978 torward, Energy Information Administration, Coal Production 1992 and prior lssues. 
References 


\section{References}

Alexander, Thomas G. "From Dearth to Deluge: Utah's Coal Industry." Utah Historical Quarterly, Volume 31, No. 3 (Summer 1963), 235-247.

Anderson, Wayne I. Geology of lowa. (Ames, IA: The Iowa State University Press, 1983.)

Appalachian Energy Associates, for Tennessee Department of Economic and Community Development, Energy Division. The Coal Industry in Tennessee, An Information and Marketing Guide. (Signal Mountain, TN, 1991).

Arizona Bureau of Mines. "Mineral and Water Resources of Arizona." Bulletin 180. (Tucson, AZ, 1969.)

Central Louisiana Electric Company, Inc., and Southwestern Electric Power Company. Dolet Hills. (Pineville, LA, no date.)

Colorado Mining Association, Coal Committee. Colorado and Mining, Coal 1992. (Denver, CO, 1993.)

Dakota Gasification Company. Great Plains Synfuels Plant. (Beulah, ND, no date.)

Destec Energy, Inc. The Dow Syngas Project. (Houston, TX, 1990.)

Eavenson, Howard N. The First Century and a Quarter of American Coal Industry. (Baltimore, MD: Waverly Press, Inc., 1942.)

Energy Information Administration. Coal Distribution January-December 1991. DOE/EIA-0125(91/4Q). (Washington, DC, April 1992) and prior issues.

Energy Information Administration. Coal Production 1992. EIA-0118(93). (Washington, DC, October 1993) and prior issues.

Energy Information Administration. Cost and Quality of Fuels for Electric Utility Plants 1992. DOE/EIA-0191(92). (Washington, DC, August 1993.)

Energy Information Administration. Electric Power Annual 1991. DOE/EIA-0348(91). (Washington, DC, February 1993) and prior issues.
Energy Information Administration. Electric Power Monthly March 1993. DOE/EIA-0226(93/03). (Washington, DC, March 1993.)

Energy Information Administration. Form EIA-3, "Quarterly Coal Consumption Report--Manufacturing Plants."

Energy Information Administration. Form EIA-5, “Coke Plant Report."

Energy Information Administration. Form ElA-6, "Coal Distribution Report."

Energy Information Administration. Form EIA-7A, "Coal Production Report."

Energy Information Administration. Inventory of Power Plants in the United States 1992. DOE/EIA-0095(92). (Washington, DC, October 1993.)

Energy Information Administration. Quarterly Coal Report October-December 1992. DOE/EIA-0121(92/4Q). (Washington, DC, May 1993) and prior issues.

Energy Information Administration. State Energy Data Report 1991, Consumption Estimates. DOE/EIA-0214(91). (Washington, DC, May 1993.)

Energy Information Administration. U.S. Coal Reserves: An Update by Heat and Sulfur Content DOE/EIA0529(92). (Washington, DC, February 1993.)

Energy Information Administration. "Wyoming Coal: An Overview." Coal Production 1991. DOE/EIA0118(91). (Washingtion, DC, October 1992.)

Geological Survey of Alabama. Alabama Coal Data for 1992. (Tuscaloosa, AL, 1992.)

Geological Survey of Alabama. "Energy Atlas of Alabama." Atlas 22. (Tuscaloosa, AL, 1990.)

Geological Survey of Wyoming. "Coal Update." Wyoming Geo-notes, No. 38 (May 1993) and prior issues. 
Governor's Office for Coal and Energy Policy, and the Kentucky Coal Association. 1991-1992 Pocket Guide, Kentucky Coal Facts. (Lexington, KY, 1991.)

"History of Coal in California." California Geology. (September 1976.)

Horton, Aaron Thomas, and Meredith A. Bloom. "1993 Prep Plant Census." Coal, Volume 98, No. 9. (September 1993), pp. 48-55.

Illinois Department of Energy and Natural Resources, Office of Coal Development and Marketing. Outlook for the Illinois Coal Industry, Report of the Illinois Coal Development Board. (Springfield, IL, 1993.)

Indiana Coal Council. Indiana Coal Facts 1992-93. (Indianapolis, IN, 1993.)

Iowa Geological Survey. "Element Geochemistry of Cherokee Group Coals (Middle Pennsylvanian) from South-Central and Southeastern Iowa." Technical Paper No. 5. (Iowa City, IA, 1984.)

Kansas Coal Commission. Kansas Coal Utilization Study. (Topeka, KS, 1988.)

Kentucky Geological Survey. "Kentucky Coal Production 1790-1988." Information Circular 32, Series XI. (Lexington, KY, 1990.)

Keystone Coal Industry Manual 1992 and prior issues. (Chicago, IL: Maclean Hunter Publishing Company, 1992.)

Lignite Energy Council. Lignite Energy Facts 1992-1993. (Bismark, ND, 1993.)

Louisiana Department of Natural Resources, Technology Assessment Division. Coal and Lignite in Louisiana. (Baton Rouge, LA, 1993.)

Louisiana Geological Survey. "Louisiana Lignite." Geological Pamphlet No. 3. (Baton Rouge, LA, 1942.)

Lyndon B. Johnson School of Public Affairs. Public Policies Affecting Lignite Development in Texas. (Austin, TX, 1977.)

Maryland Bureau of Mines. Calendar Year 1992, Seventieth Annual Report. (Frostburg, MD, 1993.)

Maryland Department of Geology, Mines and Water Resources. "Geography and Geology of Maryland." Bulletin 19. (Baltimore, MD, 1961.)
Missouri Department of Natural Resources, Division of Geology and Land Survey. Missouri Coal Commission Second Interim Report. (Jefferson City, MO, 1992.)

Missouri Department of Natural Resources, Division of Geology and Land Survey. Missouri Coal. (Rolla, MO, no date.)

Montana Coal Council. Montana Coal 1992. (Helena, MT, 1992.)

Montana Mining and Mineral Resources Research Institute, Montana College of Mineral Science and Technology. "Proceedings Montana Coal Forum." Special Publication 93. (Butte, MT, 1985.)

New Mexico Bureau of Mines and Mineral Resources. "Mineral and Water. Resources of New Mexico." Bulletin 87. (Socorro, NM, 1965.)

New Mexico Energy, Minerals and Natural Resources Department. 1992 Annual Resources Report. (Santa Fe, NM, 1992.)

Ohio Department of Development, Ohio Coal Development Office. Ohio Coal Development Agenda. (Columbus, OH, 1992.)

Oklahoma Geological Survey. "Investigation of the Coal Reserves in the Ozarks Section of Oklahoma and Their Potential Uses, Final Report of the Ozarks Regional Commission." Special Publication 74-2. (Norman, OK, 1974.)

PacifiCorp Electric Operations. Centralia Steam Electric Project. (Centralia, WA, 1985.)

PacifiCorp Electric Operations. The Centralia Coal Mine. (Centralia, WA, 1991.)

Peabody Western. A Quarter Century on Black Mesa. (Kayenta, AZ, 1992.)

Pennsylvania Coal Association. Pernsylvania Coal Data 1992. (Harrisburg, PA, 1992.)

Pennsylvania Energy Office. The Pennsylvania Energy Profile 1960-1990. (Harrisburg, PA, 1992.)

Sanders, R. B. "Coal Resources of Alaska." Alaska Geographic, Volume 9, No. 4 (1982).

Tennessee Department of Conservation and Commerce, Division of Geology. "The Coal Industry of Tennessee." Information Circular No. 10. (Nashville, TN, 1960.) 
Tennessee Eastman Company. Eastman Chemicals from Coal. (Kingsport, TN, no date.)

The Pennsylvania Academy of Science. Pennsylvania Coal: Resources, Technology, and Utilization. (Easton, IH, 1983.)

The Texas Utilities System. Lignite: Texas Energy for Texans. (Dallas, TX, no date.)

The University of Texas, Bureau of Economic Geology. "Lignites of the Texas Gulf Coastal Plain." Report of Investigations No. 50. (Austin, TX, 1963.)

Usibelli Coal Mine, Inc. (Alaska). UCM Usibelli Coal Miner, Volume 12 (September 1992.)

Usibelli Coal Mine, Inc. (Alaska). Data Sheet. (Healy, AK, 1993.)

1993 U.S. Coal Export Manual. (Washington, DC: Fieldston Publications, Inc., 1993.)

U.S. Department of the Interior, Bureau of Mines. "American Lignites: Geological Occurrence, Petrographic Composition, and Extractable Waxes." Bulletin 482. (Washington, DC, 1950.)

U.S. Department of the Interior, Bureau of Mines. Minerals Yearbook (various issues and predecessor reports.) (Washington, DC.)

U.S. Department of the Interior, Bureau of Mines. State Mineral Summaries 1993. (Washington, DC, 1993.)

U.S. Department of the Interior, Geological Survey. "1992 Annual Report on Alaska's Mineral Resources." Circular 1091. (Denver, CO, 1992.)

U.S. Department of the Interior, Geological Survey. Coal Fields of the United States (map). (Washington, DC, 1960.)

U.S. Department of the Interior, Geological Survey. Coal Map of North America. (Denver, CO, 1988.)

U.S. Department of the Interior, Geological Survey. "Mineral and Water Resources of Washington." Com- mittee Print, 89th Congress, $2 d$ Session. (Washington, DC, 1966.)

U.S. Department of the Interior, Geological Survey. "Mineral and Water Resources of Utah." Committee Print, 88th Congress, $2 d$ Session. (Washington, DC, 1964.)

U.S. Department of the Interior, Minerals Management Service. Mineral Revenues 1992, Report on Receipts from Federal and Indian Leases. (Denver, CO, 1993.)

U.S. Department of Transportation, Maritime Administration. Existing and Potential U.S. Coal Loading Terminals. (Washington, DC, 1992.)

Virginia Department of Mines, Minerals, and Energy. Virginia Energy Patterns and Trends. Virginia Energy Profiles: 1960 to 1990. (Richmond, VA, 1991.)

Virginia Division of Mineral Resources. "Mining History of the Richmond Coalfield of Virginia." Publication 85. (Charlottesville, VA, 1988.)

Virginia Polytechnic Institute and State University, Virginia Center for Coal and Energy Research. 1993 Virginia Coal. (Blacksburg, VA, 1993.)

Virginia Polytechnic Institute and State University, Virginia Center for Coal and Energy Research. Virginia Coal-An Abridged History. (Blacksburg, VA, 1990.)

Washington Department of Natural Resources, Division of Geology and Earth Resources. "Coal Activity in Washington--1992." Washington Geology, Volume 21, No. 1 (March 1993), 31-32.

West Virginia Coal Association. Coal Facts '92. (Charleston, WV, 1992.)

West Virginia Geological and Economic Survey. "Coal and Coal Mining in West Virginia." Coal-Geology Bulletin No. 2. (Morgantown, WV, 1974.)

Williamson, David Ray. "Lignite of Northwest Louisiana and the Dolet Hills Lignite Mine." Gulf Coast Lignite Geology. (Reston, VA: Environmental and Coal Associates, 1987.) 
Appendix A

National Rankings of Coal Producing States and Percent of U.S.

Total, 1992 


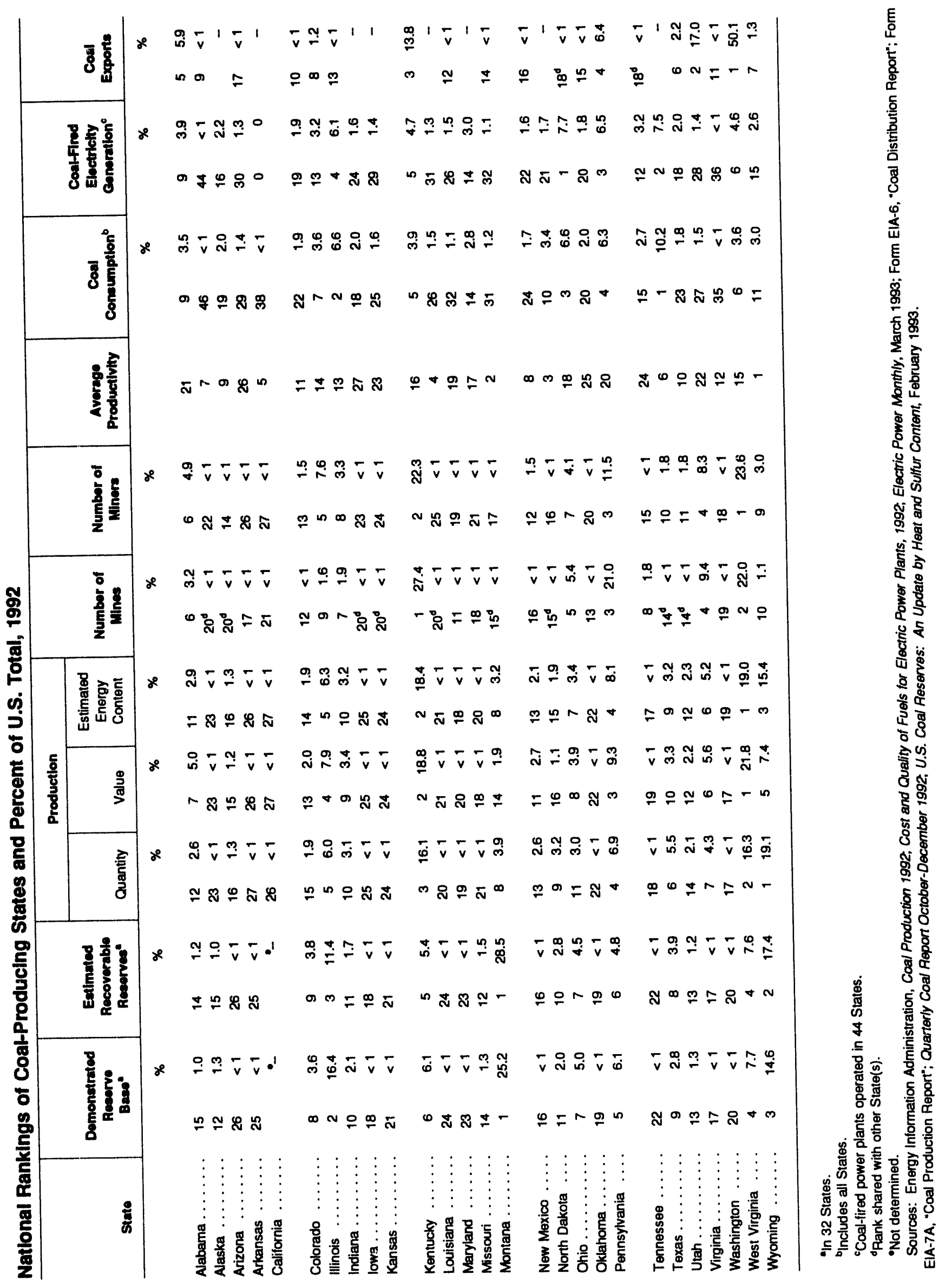


Appendix B

State Agencies and Other Organizations Concerned wtih Coal and Energy 


\section{Appendix B}

\section{State Agencies and Other Organizations Concerned with Coal and Energy}

\section{ALABAMA}

Alabama Coal Association, Vestavia Commerce Centre, 2090 Columbiana Road, Suite 2500, Birmingham, AL 35216; (205) 822-0384.

Alabama Department of Conservation and Natural Resources, State Lands Division, 64 North Union St., Montgomery, AL 36130-1901; (205) 242-3484.

Alabama Department of Economic and Community Affairs, Division of Science, Technology and Energy, P.O. Box 5690, Montgomery, Al 36103-5690; (205) 242-5100.

Alabama Department of Industrial Relations, Abandoned Mines Reclamation Commission, 11 West Oxmore, Suite 100, Birmingham, AL 35209; (205) 945-8671.

Alabama Department of Industrial Relations, Division of Safety and Inspection, P.O. Box 10444, Birmingham, AL 35202; (205) 254-1275.

Alabama Development Office, Alabama Center for Commerce, 401 Adams Avenue, Montgomery, AL 36130; (205) 242-0400.

Alabama Energy Office, Department of Economics and Community Affairs, Science Technology and Energy Division, P. O. Box 5690, Montgomery, AL 36103-5690; (205) 223-7008.

Alabama Surface Mining Commission, P.O. Box 2390, Jasper, AL 35502-2390; (205) 221-4130.

Coalbed Methane Association of Alabama, 1855 Data Drive, Suite 160, Birmingham, AL 35244; (205) 733-8087.

Geological Survey of Alabama, 420 Hackberry Lane, Box O, Tuscaloosa, AL 35486-9780; (205) 349-2852.

The University of Alabama, Mineral Resources Institute, Box 870204, Tuscaloosa, AL 35487-0204; (205) 348-2044.

The University of Alabama, School of Mines and Energy Development, Box 870164, Tuscaloosa, AL 35487-0164; (205) 348-4520.

\section{ALASKA}

Alaska Coal Association, 122 First Ave., Suite 302, Fairbanks, AK 99701; (907) 452-2625.

Alaska Department of Commerce and Economic Development, Division of Energy and Power Development, State Office Building, P.O. Box 110804, Juneau, AK 99811-0804; (907) 465-2017.

Alaska Department of Environmental Conservation, 410 Willoughby Avenue, Suite 105, Juneau, AK 99811-1795; (907) 465-5280. 
Alaska Department of Natural Resources, Division of Geological and Geophysical Surveys, 794 University Avenue, Suite 200, Fairbanks, AK 99709-3645; (907) 474-7147.

Alaska Department of Natural Resources, Division of Mining, Box 107016, Anchorage, AK 99510-7016; (907) 762-2165. Alaska Energy Office, Rural Development Division, Energy Programs, 333 W. 4th Avenue, Suite 220, Anchorage, AK 99501-2341; (907) 269-4500.

Alaska Miners Association, 501 W. Northern Lights Blvd., Suite 203, Anchorage, AK 99503-2565; (907) $276-0347$.

Coal Operators and Alaska Leaseholders, P. O. Box 1000, Healy, AK 99743; (907) 683-2226.

\section{ARIZONA}

Arizona Department of Environmental Quality, 1502 West Washington, Phoenix, AZ 85007; (602) 257-2300.

Arizona Department of Mines and Resources, Mineral Building, State Fairgrounds, 1502 West Washington, Phoenix, AZ 85007; (602) 255-3791.

Arizona Energy Office of the Department of Commerce, 3800 North Central Avenue, Suite 1200, Phoenix, AZ 85012; (602) 280-1402.

Arizona Geological Survey, 845 North Park Avenue, Suite 100, Tucson, AZ 85719; (602) 882-4795.

Arizona State Land Department, 1616 West Adams, Phoenix, AZ 85007; (602) 542-4628.

Arizona State Mine Inspector, 1700 West Washington, Suite 400, Phoenix, AZ 85007; (602) 542-5971.

Salt River Project, P.O. Box 52025, Phoenix, AZ 85072-2025; (602) 236-5900.

\section{ARKANSAS}

Arkansas Department of Labor, State Mine Inspection Division, 616 Garrison, Suite 205, Forth Smith, AR 72901; (501) 783-2103.

Arkansas Department of Pollution Control and Ecology, Mining Division, 8001 National Drive, Little Rock, AR 72209; (501) 562-7444.

Arkansas Energy Office, No. 1 State Capitol Mall, Suite 4B215, Little Rock, AR 72201; (501) 682-7315.

Arkansas Geological Commission, 3815 West Roosevelt Road, Little Rock, AR 72204; (501) 663-9714.

\section{CALIFORNIA}

California Department of Conservation, State Mining and Geology Board, $801 \mathrm{~K}$ Street, MS09-05, Sacramento, CA 95814; (916) 322-1082.

California Division of Mines and Geology, $801 \mathrm{~K}$ Street, MS12-30, Sacramento, CA 95814; (916) 445-1923.

California Energy Commission, 1516 9th St., Sacramento, CA 95814; (916) 654-4287.

California Occupational Safety and Health, Mining and Tunneling, 1209 Woodrow Ave., Suite C4, Modesto, CA 95350; (209) 576-6241. 


\section{COLORADO}

Colorado Department of Natural Resources, Colorado Geological Survey, 1313 Sherman Street, Rm. 715, Denver, CO; 80203-2273; (303) 866-2611.

Colorado Department of Natural Resources, Division of Minerals and Geology, 1313 Sherman St., Rm. 215, Denver, CO 80203- 73 ; (303) 866-3401.

Colorado Department of Natural Resources, Office of Active and Inactive Mines, 1313 Sherman Street, Rm. 215, Denver, CO 80203-2273; (303) 826-3567.

Colorado Mining Association, 1340 Colorado State Bank Building, 1600 Broadway, Denver, CO 80202; (303) 894-0536.

Colorado Office of Energy Conservation, 1675 Broadway, Suite 1300, Denver, CO 80202-4613; (303) 620-4292.

Energy Minerals Field Institute, Colorado School of Mines, EMFI Department, Golden, CO 80401; (303) 273-3900.

Northwest Colorado Energy Producers, P.O. Box 68, Craig, CO 81626; (303) 824-8246.

Rocky Mountain Coal Mining Institute, 3000 Youngfield St., Suite 324, Lakewood, CO 80215; (303) 238-9099.

Western Coal Transportation Association, 5555 DTC Parkway, Greenwood Village, CO 80111; (303) 694-6611.

\section{ILLINOIS}

Coal Producers Association of Illinois, 401-3 Harrisburg National Bank Building, Harrisburg, IL 62946; (618) $252-8321$.

Illinois Coal Association, 212 South Second St., Springfield, IL 62701; (217) 528-2092.

Illinois Department of Energy and Natural Resources, Office of Coal Development and Marketing, 325 West Adams St., Rm. 300, Springfield, IL 62704; (217) 785-2800.

Illinois Department of Energy and Natural Resources, State Geological Survey, Natural Resources Building, 615 East Peabody Drive, Champaign, IL 61820; $(21 ;)$ 333-5111.

Illinois Department of Mines and Minerals, 300 West Jefferson St., Suite 300, Springfield, IL 62719-0137; (618) 4399111.

Illinois Environmental Protection Agency, 2200 Churchill Road, Springfield, IL 62706; (217) 782-3397.

Progressive Mine Workers of America, Rt. 34, P.O. Box 640, Harrisbuig, IL 62946; (618) 252-5321.

\section{INDIANA}

Indiana Bureau of Mines and Mining, 6 Northeast 21st 3t., Washington, IN 47501; (812) 254-1040.

Indiana Coal Association, 5349 Washington Blvd., Indianapolis, IN 46220; (317) 257-1993.

Indiana Coal Council, Inc., 143 W. Market St., Indianapolis, IN 46204; (317) 638-6997.

Indiana Department of Commerce, Office of Energy Policy Division, 1 North Capitol, Indianapolis, IN 46204-2288; (317) 232-8940. 
Indiana Department of Environmental Management, 100 North Centate, P.O. Box 6015, Indianapolis, IN 46206-6015; (317) 232-8162.

Indiana Department of Natural Resources, Division of Reclamation, 402 West Washington St., W2-95, Indianapolis, IN 46204; (317) 232-1547.

Indiana Geological Survey, 611 North Walnut Grove Avenue, Bloomington, IN 47405; (812) 855-9350.

\section{IOWA}

Iowa Department of Agriculture and Land Stewardship, Division of Soil Conservation, Wallace State Office Building, Des Moines, IA 50319; (515) 281-6147.

Iowa Department of Natural Resources, Energy and Geological Resources Division, Geological Survey Bureau, 109 Trowbridge Hall, Iowa City, IA 52242; (319) 335-1575.

Iowa Department of Natural Resources, Energy and Geological Resources Division, Wailace State Office Building, Des Moines, IA 50319; (515) 281-6682.

Iowa State University, Iowa State Mining and Mineral Reseurces Research Institute, 280 Metals Development Building, Ames, IA 50011; (515) 294-3758.

\section{KANSAS}

Kansas Corporation Commission, Energy Division, 1500 S.W. Arrowhead Road, Topeka, KS 66604; (913) 271-3170. Kansas Department of Health and Environment, Mining Section, Box 1418, Pittsburg, KS 66762; (316) 231-8540.

Kansas Geological Survey, 1930 Constant Avenue, The University of Kansas, Lawrence, KS 66047; (913) 864-3965.

Technology Enterprise Corporation of Kansas, 112 West 6th Street, Suite 400, Topeka, KS 66603; (913) $296-5272$.

\section{KENTUCKY}

Governor's Office for Coal and Energy Policy, 3572 Iron Works Pike, Box 11888, Lexington, KY 40578-1916; (wu6) 2525535.

Harlan County Coal Operators Association, P.O. Box 230, Harlan, KY 40831; (606) 573-2656.

Institute for Mining and Minerals Research, 233 Mining and Mineral Resources Building, University of Kentucky, Lexington, KY 40506-0107; (606) 257-8636.

Kentucky Coal Association, 340 South Broadway, Lexington, KY 40508; (606) 233-4743.

Kentucky Coal Marketing and Export Council, Division of Energy, 2100 Capital Plaza Tower, 500 Mero Street, Frankfort, KY 40601; (502) 564-7140.

Kentucky Coal Operators \& Associates, Inc., 642 North Mayo Trail, P.O. Box 3158, Pikeville, KY 41502; (606) 432-2161. Kentucky Department of Mines and Minerals, 3572 Iron Works Pike, Box 14080, Lexington, KY 40512; (606) 254-0367. Kentucky Department for Surface Mining Reclamation and Enforcement, 2 Hudson Hollow, Frankfort, KY 40601; (502) 564-6940. 
Kentucky Environmental Protection Department, Fort Boone Plaza, 18 Reilly Rd., Frankfort, KY 40601; (502) 564-2150.

Kentucky Geological Survey, 228 Mining and Mineral Resources Building, University of Kentucky, Lexington, KY 40506-0107; (606) 257-5863.

Kentucky Natural Resources and Environmental Protection Cabinet, Energy Division, 691 Teton Trail, Frankfort, KY 40601; (502) 564-7192.

Kentucky Reclamation Association, 1850 Lantaff Blvd., Madisonville, KY 42431; (502) 821-2760.

Kentucky Small Operators Assistance Program, 2 Hudson Hollow, Frankfurt, KY 40601; (502) 564-2356.

Kentucky-Tennessee Coal Operators Association, P.O. Box 281, Corbin, KY 40701; (606) 528-9481.

Western Kentucky Coal Association, P.O. Box 4148, Frankfurt, KY 40604; (502) 223-1437.

\section{LOUISIANA}

Louisiana Department of Natural Resources, Energy Office, P.O. Box 94396, Baton Rouge, LA 70804-9396; (504) 3424534.

Louisiana Department of Natural Resources, Geological Survey, Box G, University Station, Baton Rouge, LA 70893; (504) 388-5320.

Louisiana Department of Natural Resources, Office of Conservation, Injection and Mining Division, Box 94275, Capital Station, Baton Rouge, LA 70804; (504) 342-5515.

Louisiana Department of Natural Resources, Office of Mineral Resources, Geological and Engineering Division, Box 2827, Baton Rouge, LA 70821; (504) 342-4433.

\section{MARYLAND}

Maryland Bureau of Mines, 160 South Water St., Frostburg, MD 21532; (301) 689-6104.

Maryland Coal Association, 59 E. Main St., Frostburg, MD 21532; (301) 689-6609.

Maryland Energy Administration, 45 Calvert St., 4th Floor, Annapolis, MD 21401; (410) 974-3751.

Maryland Geological Survey, 2300 St. Paul St., Baltimore, MD 21218; (410) 554-5503.

\section{MISSOURI}

Mining Industry Council of Missouri, P.O. Box 725, Jefferson City, MO 65102; (314) 635-7308.

Missouri Department of Labor and Industrial Relations, Division of Labor Standards, P.O. Box 449, Jefferson City, MO 65102; (314) 751-3403.

Missouri Department of Natural Resources, Division of Energy, P.O. Box 176, Jefferson City, MO 65012; (314) 7514000.

Missouri Department of Natural Resources, Division of Geology and Land Survey, 111 Fairgrounds Road, P.O. Box 250, Rolla, MO 65401; (314) 368-2100. 
Missouri Department of Natural Resources, Land Reclamation Commission, 111 Fairgrounds Road, P.O. Box 250, Rolla, MO 65401; (314) 751-4041.

Missouri Land Reclamation Commission, P.O. Box 176, Jefferson City, MO 65102; (314) 751-4041.

University of Missouri--Rolla, Mining and Mineral Resources Research Institute, 104 Mining Building, Rolla, MO 65401; (314) 341-4153.

\section{MONTANA}

Montana Bureau of Mines and Geology, Montana College of Mineral Science and Technology, Butte, MT 59701; (406) 496-4180.

Montana Department of Natural Resources and Conservation, Energy Division, 1520 East Sixth Avenue, Helena, MT 59620-2301; (406) 444-6812.

Montana Department of Labor and Industry, Division of Workers Compensation, Safety Bureau, Mining Section, P.O. Box 1728, Helena, MT 59624; (406) 444-6401.

Montana Department of State Lands, Capitol Station, 1625 11th Avenue, Helena, MT 59620; (406) 444-2074.

Montana Mining Association, 2301 Colonial Drive, Helena, MT 59601; (406) 442-6223.

\section{NEW MEXICO}

New Mexico Bureau of Mines and Mineral Resources, Campus Station, Socorro, NM 87801; (505) 835-5410.

New Mexico Department of Energy, Minerals, as d Natural Resources, Mining and Minerals Division, 2040 South Pacheco, Santa Fe, NM 87505; (505) 827-5970.

New Mexico Department of Energy, Minerals, and Natural Resources, Energy Conservation and Management Division, 2040 South Pacheco, Santa Fe, NM 87505; (505) 827-5900.

New Mexico Mining Association, 6020 Academy NE, Suite 201, Albuquerque, NM, 87109; (505) 857-0377.

\section{NORTH DAKOTA}

North Dakota State Land Development, Energy Impact Officer, 918 East Divide Avenue, Suite 410, P.O. Box 5523, Bismark, ND 58502-5523; (701) 224-3188.

Lignite Energy Council, 1016 E. Owens Avenue, P.O. Box 2277, Bismark, ND 58502; (701) 258-7117.

North Dakota Geological Survey, 600 East Boulevard, Bismark, ND 58505-0840; (701) 224-4109.

North Dakota Mining and Mineral Resources Research Institute, Energy and Environment Research Center, University of North Dakota, Box 9018, University Station, Grand Forks, ND 58202; (701) 777-4574.

North Dakota Office of State Tax Commissioner, Utility Tax Auditor, State Tax Department, State Capitol Building, 600 East Building Ave., Bismark, ND 58505; (701) 224-2770.

North Dakota Public Service Commission, Reclamation Division, Capitol Building, 12th Floor, Bismark, ND 585050480; (701) 224-2400. 


\section{OHIO}

Ohio Coal Development Office, Community Development Division, Office of Energy Efficiency, 77 S. High St., Columbus, OH 43266-0413; (614) 466-6797.

Ohio Department of Industrial Relations, Mine Division, 2323 W. 5th Avenue, Box 825, Columbus, OH 43266-0567; (614) 644-2234.

Ohio Department of Natural Resources, Geological Survey Division, 4383 Fountain Square Drive, Columbus, OH 43224-1362; (614) 265-6576.

Ohio Mining \& Reclamation Association, 50 S. Young St., Columbus, OH 43215; (614) 228-6336.

Ohio Valley Coal Operators Association, 209 Lew-Port Building, 100 W. Main St., St. Clairsville, OH 43950; (614) 6952214.

\section{OKLAHOMA}

Association of Oklahoma General Contractors, 301 N.E. Expressway, P.O. Box 43152, Oklahoma City, OK 73105; (405) 843-5661.

Oklahoma Conservation Commission, 2800 North !.incoln, Suite 160, Oklahoma City, OK 73105; (405) 521-2384.

Oklahoma Department of Commerce, Division of Community Affairs and Development, 6601 Broadway Extension, Oklahoma City, OK 73116; (405) 841-9326.

Oklahoma Department of Mines, 4040 N. Lincoln, Oklahoma City, OK 73105; (405) 521-3859.

Oklahoma Geological Survey, University of Oklahoma, The Energy Center, 100 East Boyd, Room N131, Norman, OK 73019-0628; (405) 325-3031.

University of Oklahoma, Mining \& Mineral Resources Research Institute, 100 East Boyd, Norman, OK 73019; (405) 325-5811.

\section{PENNSYLVANIA}

Pennsylvania Coal Association, 212 North Third St., Harrisburg, PA 17101; (717) 233-7900.

Pennsylvania Department of Environmental Resources, Bureau of Deep Mine Safety, Market Street State Office Building, 400 Market Street, P.O. Box 8463, Harrisburg, PA 17105-8463; (717) 783-7515.

Pennsylvania Department of Environmental Resources, Bureau of Mining and Reclamation, P.O. Box 8461, Executive House \#209, 2nd and Chestnut St., Harrisburg, PA 17105; (717) 787-5103.

Pennsylvania Department of Environmental Resources, Bureau of Topographic and Geologic Survey, P.O. Box 8453, Evangelical Press Building, Third and Reily Streets, Harrisburg, PA 17105-8453; (717) 787-2169.

Pennsylvania Energy Development Authority, 116 Pine St., Harrisburg, PA 17101; (717) 783-9981.

Western Pennsylvania Coal Operators Association, Box 123, West Sunbury, PA 16061; (412) 637-2453. 


\section{TENNESSEE}

Kentucky-Tennessee Coal Operators Association, P.O. Box 281, Corbin, KY 40701; (606) 528-9481.

State of Tennessee Department of Labor, Division of Mines, P.O. Box 124, Caryville, TN 37714; (615) 562-4914.

Tennessee Coal Association, P.O. Box 12248, Knoxville, TN 37912; (615) 688-6080.

Tennessee Department of Conservation, Division of Geology, 401 Church Street, 13th Floor, Nashville, TN 37243-0445; (615) 532-1500.

Tennessee Department of Economic and Community Development, Energy Division, 32U 6th Avenue North, Nashville, TN 37219; (615) 741-2372.

Tennessee Department of Health and Environment, Division of Surface Mining, 2700 Middlebrook Pike, Knoxville, TN 37921; (615) 594-6035.

\section{TEXAS}

Bureau of Economic Geology, The University of Texas at Austin, University Station, Box X, Austin, TX 78713-7508; (512) 471-7721.

Railroad Commission of Texas, Surface Mining and Reclamation Division, Capitol Station, P.O. Box 12967, Austin, TX 78711; (512) 463-7288.

Texas Energy Office, Capitol Station, P.O. Box 13047, Austin, TX 78711; (512) 463-1931.

Texas General Land Office, Energy Resources Division, Stephen F. Austin Building, 1700 North Congress Avenue, Austin, TX 78701; (512) 463-5022.

Texas Mining \& Reclamation Association, 300 Highland Mall Boulevard, Austin, TX 78752; (512) 467-1300.

\section{UTAH}

Utah Coal Operators Association, c/o Valley Camp of Utah, Inc., Scofield Route, Helper, UT 84526; (801) 448-9420.

Utah Division of Oil, Gas and Mining, 3 Triad Center, Suite 350, 355 West North Temple, Salt Lake City, UT 841801203; (801) 538-5340.

Utah Energy Office, 355 West North Temple, 3 Triad Center, Salt Lake City, UT 84180-1204; (801) 538-5428.

Utah Geological and Mineral Survey, 2363 South Foothill Drive, Salt Lake City, UT 84109; (801) 467-7970.

Utah Mining Association, 825 Kearns Building, Salt Lake City, UT 84101; (801) 364-1874.

\section{VIRGINIA}

National Independent Coal Operators Association, 1514 Front St., P.O. Box 354, Richlands, VA 24641; (703) 964-6065.

Virginia Center for Coal and Energy Research, Virginia Polytechnic Institute and State University, 617 Main St., Blacksburg, VA 24060-0411; 1-800-552-3831.

Virginia Coal Association, 425 Old City Hall, 1001 E. Broad St., Richmond, VA 23219; (804) 643-6697. 
Virginia Coal Council, 1901 Front St., P.O. Box X, Richlands, VA 24641; (703) 964-6363.

Virginia Department of Mines, Minerals, and Energy, Division of Energy, 2201 West Broad St., Richmond, VA 23220; (804) $367-6851$.

Virginia Department of Mines, Minerals, and Energy, Division of Mineral Resources, Alderman and McCormick Roads, Box 3667, Charlottesville, VA 22903; (804) 293-5121.

Virginia Department of Mines, Minerals, and Energy, Division of Mineral Mining, 7705 Timberlake Road, Box 4499, Lynchburg, VA 24502; (804) 239-0602.

Virginia Department of Mines, Minerals, and Energy, Division of Mines, 2201 West Broad St., Richmond, VA 23220; (804) 367-0330.

Virginia Department of Mines, Minerals, and Energy, Division of Mines, 219 Wood Road, Big Stone Gap, VA 24219; (703) 523-0335.

Virginia Mining \& Reclamation Association, 18 Seventh St., Park Avenue Center, Suite 203, Norton, VA 24273; (703) 679-0456.

\section{WASHINGTON}

Northwest Mining Association, 414 Peyton Building, Spokane, WA 99201; (509) 624-1158.

Washington Department of Labor and Industries, Division of Industrial Safety and Health, Technical Services Division, Box 44651, Building \#6, Olympia, WA 98504; (206) 956-5642.

Washington Department of Natural Resources, Division of Geology and Earth Resources, Mail Stop 47007, Olympia, WA 98504; (206) 902-1450.

Washington Department of Natural Resources, Division of Lands and Minerals, Mail Stop 47014, Olympia, WA 98504; (206) 902-1600.

Washington State Energy Office, 925 Plum, Olympia, WA 98504; (206) 956-2000.

\section{WEST VIRGINIA}

Governor's Office of Community and Industrial Development, Building 6, 553 Capitol Complex, Charleston, WV 25305; (304) 558-4010.

Tri-State Coal Operators Association, Inc., P.O. Box 259, Kingwood, WV 26537; (304)-329-0976.

West Virginia Coal Association, 1301 Laidley Tower, Charleston, WV 25301; (304) 342-4153.

West Virginia Department of Commerce, Labor and Environmental Resources, Office of Miner's Health and Safety Training, State Capitol Complex, Bldg. 1, Rm. M1-46, 1900 Kanawha Boulevard East, Charleston, WV 25305-0310; (304) 558-0400.

West Virginia Division of Natural Resources, State Capitol Complex, Building 3, 1900 Kanawha Boulevard East, Charleston, WV 25305 (304) 558-2754.

West Virginia Geological and Economic Survey, Mont Chateau Research Center, Box 879, Morgantown, WV 265070879; (304) 594-2331. 
West Virginia Mining \& Reclamation Association, 1624 Kanawha Boulevard East, Charleston, WV 25311; (304) 3465318.

\section{WYOMING}

Geological Survey of Wyoming, P.O. Box 3008, University Station, Laramie, WY 82701; (307) 766-2286.

Wyoming Department of Commerce, Division of Economic and Community Development, Barrett Building, Cheyenne, WY 82002; (307) 777-7284.

Wyoming Department of Revenue, Mineral Tax Division, Herschler Building, 122 W. 25th St., Cheyenne, WY $82002-$ 0110; (307) 777-7215.

Wyoming Mining Association, 1700 West Lincoln Way, Cheyenne, WY 82001; (307) 635-0331.

Wyoming State Inspector of Mines, P.O. Box 1094, Northwide State Bank Building, Rock Springs, WY 82902; (307) 362-5222. 
\begin{tabular}{l} 
옹 \\
8 \\
8 \\
\hline
\end{tabular} 


\section{Glossary}

Anthracite: A hard, black, lustrous coal (sometimes called "hard coal"); the highest rank of coal in the coalification series, with a high heat value and low sulfur content; relatively sn:all amounts are mined in northeastern Pennsylvania.

Ash: Impurities consisting of silica, iron, alumina, and other incombustible matter.

Bituminous coal: The most common coal; ranks between anthracite and subbituminous coal in the coalification series; includes coal with the highest heat value and a wide range in sulfur content; mined predominantly in Appalachia.

Btu (British thermal unit): The amount of heat needed to raise the temperature of 1 pound of water (approximately 1 pint) by 1 degree Fahrenheit; a convenient measure by which to compare the energy content of various fuels.

Coal gasification: The process of breaking down the molecular structure of coal to produce hydrogen and carbon, which can be combined to form synthetic natural gas for energy use or, if further processed, to produce chemicals. Coal gasification plants are in North Dakota, Louisiana, and Tennessee.

Coal preparation plant: A facility where coal is crushed, screened, and cleaned to remove impurities such as rock and sulfur, and to meet market specifications.

Coke: Produced from coking (metallurgical) coal, coke is hard and porous; used mainly as a fuel and reducing agent in a blast furnace to smelt iron ore for steelmaking.

Coking coal (metallurgical coal): A bituminous coal, low in ash and sulfur, that can be converted into coke when baked in an oven; in practice, several coals are blended to produce coke.

Demonstrated Reserve Base of coal: The part of the coal in the ground (coal resource) that meets certain criteria for geologic reliability and economic minability; the starting point for most coal supply analyses.
Federal coal lease: A lease granted to a mining company to produce coal from land owned and administered by the Federal Government in exchange for royalties and other revenues.

Indian coal lease: A lease granted to a mining company to produce coal from Indian lands in exchange for royalties and other revenues; obtained by direct negotiation with the Indians, but subject to approval and administration by the U.S. Department of the Interior.

Lignite: Coal that ranks below subbituminous coal in the coalification series, with the lowest heat value and a low sulfur content; generally not economical to ship long distances because of its low heat content and its potential for spontaneous combustion when stored for extended periods; produced as a fuel in Texas, North Dakota, Louisiana, and Montana, and as a source of montan wax in California.

Open-pit coal mine: A surface mine that produces from steeply inclined coalbeds.

Recoverable Reserves of coal: The part of the Demonstrated Reserve Base that can be economically recovered after allowing for environmental, legal, and technologic constraints.

Subbituminous coal: Coal that ranks between bituminous coal and lignite in the coalification series; generally has a low sulfur content and a comparatively low heat value; produced in the West and Alaska.

Sulfur: One of the elements present in varying quantities in coal that contributes to environmental degradation when coal is burned; occurs most commonly as the mineral pyrite.

Surface coal mine: A. mine where the soil and rock (overburden) are removed to expose the coalbed, which is then excavated with equipment such as power shovels and front-end loaders.

Underground coal mine: A mine in which tunneling is used to reach the coalbed, which is then excavated with various types of equipment. 

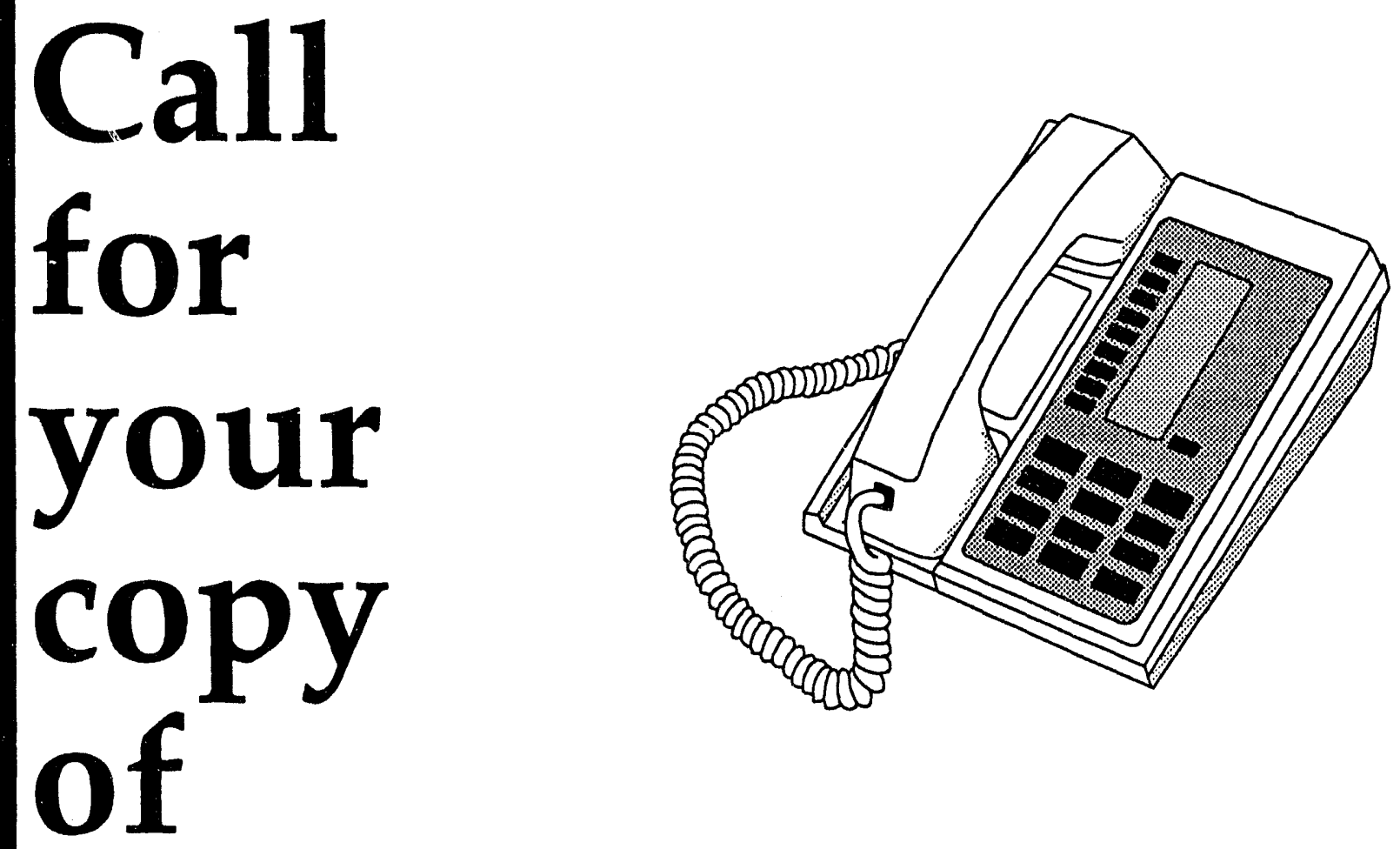

\section{EIA New Releases}

A concise and timely review of new statistical publications and energy news

Offered from the National Energy Information Center

For a complimentary copy of this bimonthly bulletin, or a complimentary subscription, call (202)586-8800. 

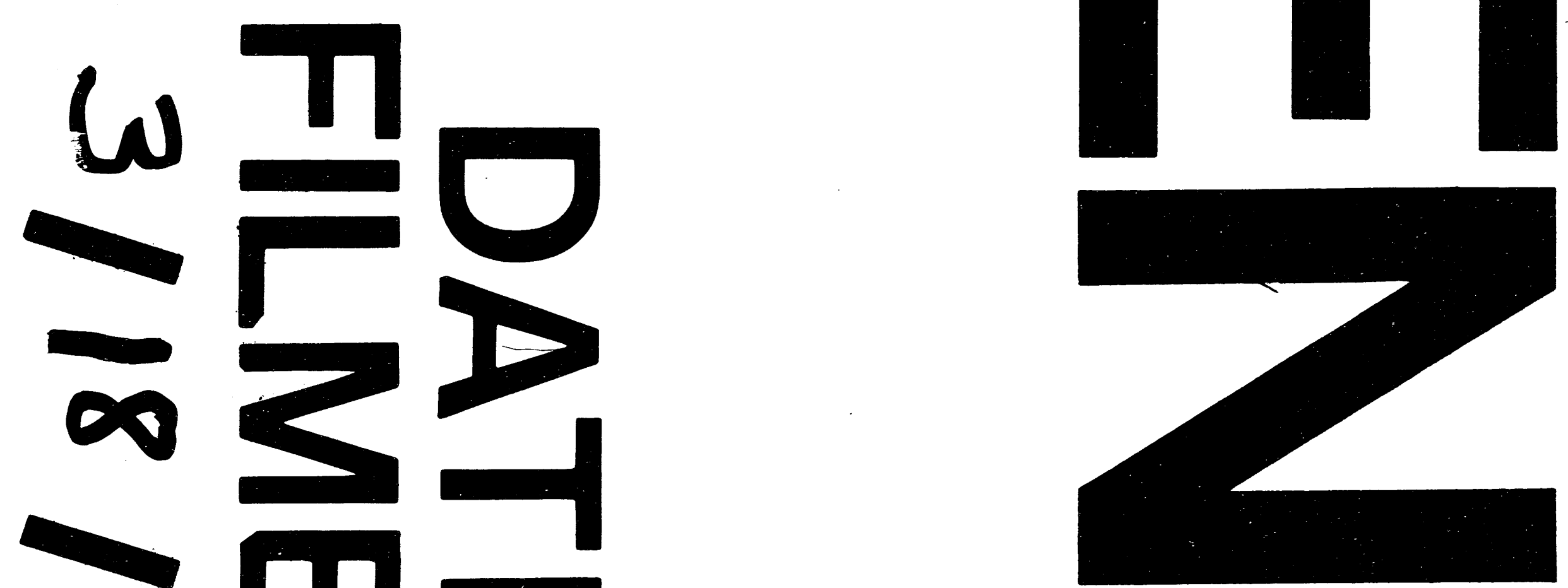

$x$ m

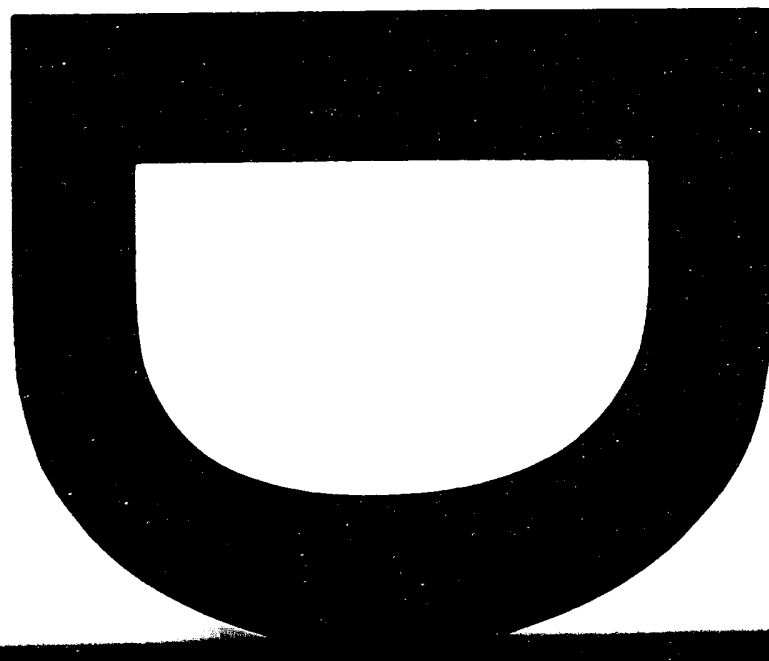


